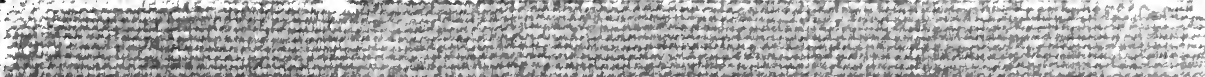
of Q

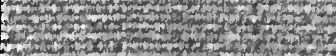
tow

校

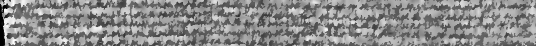

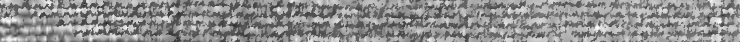

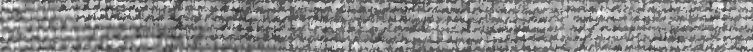

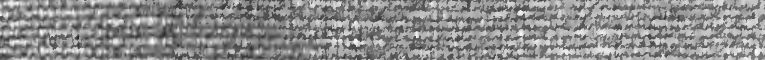

W

The

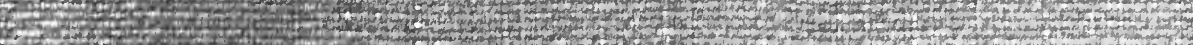

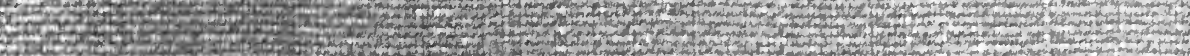

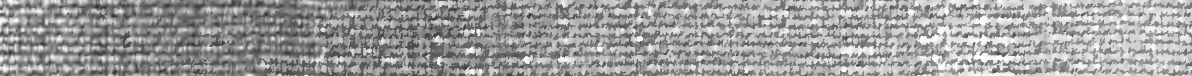

ats.

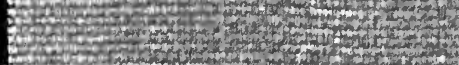

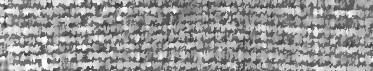

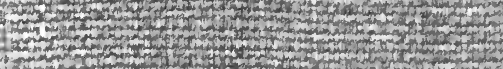

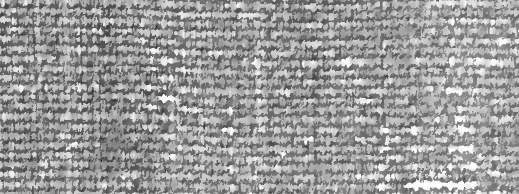

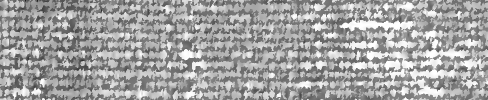

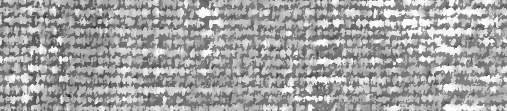

\%$$
\text { , }
$$ 



2 



\section{- THE TRANSIT OF CIVILIZATION FROM ENGLAND TO AMERICA IN THE SEVENTEENTH CENTURY}

BY

\section{EDWARD EGGLESTON}

AUTHOR OF THE BEGINNERS OF A NATION
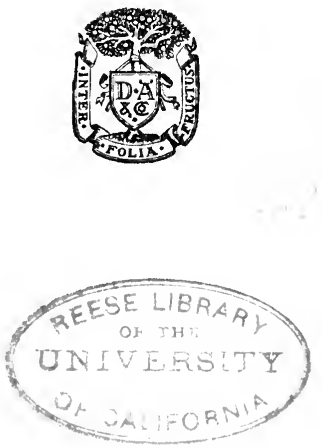

NEW YORK

D. APPLETON AND COMPANY 
Copyright, igoo,

By EDWARD EGGLESTON. 
TO FRANCES MY WIFE 



\section{Fla}

\section{PREFACE.}

IN seeking to give a history of the civilization of the seventeenth century there was little help in anything American, and, to my surprise, I found long ago that I could not count on anything English. There were many books on Shakespeare, more or less good when they were not bad, and there was Masson's ponderous Life and Times of John Milton in six octavo volumes. These afforded something, but the civilization of the century was not told in any of them. It became necessary to build a description from the ground. The complex states of knowing and thinking, of feeling and passion, must be explained. The little world as seen by the man of the seventeenth century must be understood. Its sun, moon, and planets were flames of fire without gravity, revolved about the earth by countless angels; its God governed this one little world with mock majesty. Its heaven, its horrible hell of material fire blown by the mouth of God, its chained demons whose fetters might be loosed, its damnation of infants were to be appreciated and expounded. The inhumanity of punishments and of sport in that day, the mixture made of religion and revenge-these and a hundred other things went to make up the traits of the century. To explain the things in this other age in which I found myself it was necessary to go to England. To understand England one must understand the Continent; to make this out one must of ten thread his way to antiquity. The use of Latin by nearly all scholars made the world's knowledge more 
Preface. or less common to all. My little corner widened out into a part of all human history.

Eclipses, parhelia, comets, were danger signals hung out in the heavens as warnings. Logic was the only implement for the discovery of truth. Observation was in its birth throes. Medicines were recognized by signaturism; on this slender basis what a towering structure was built! Right and wrong were thought of only as the result of direct revelation; they had not yet found standing room in the great theater of natural knowledge. Until we understand these things we write the history of the seventeenth century in vain. It is the last age which sought knowledge of physical things by deduction. The next century brought philosophy and philosophy dawned into science.

We must apply to the seventeenth century the severe canons of history; people with ancestors will be disappointed. We can not make out in the seventeenth century the great destiny of Virginia in the eighteenth. We must not be sure that the future greatness of later New England is wrapped up in the peculiarly narrow and forbidding husk of the later seventeenth century. Nor can commercial greatness be predicted of New York; nor did Pennsylvania show signs of the great industries developed from her coal fields. The causes of greatness are not always traceable. Where least looked for may develop the next group of statesmer and authors, of inventors and great merchants. We may write history, but we may not prophesy.

Joshua's Rock, Lake George, November, 1900. 


\section{CONTENTS.}

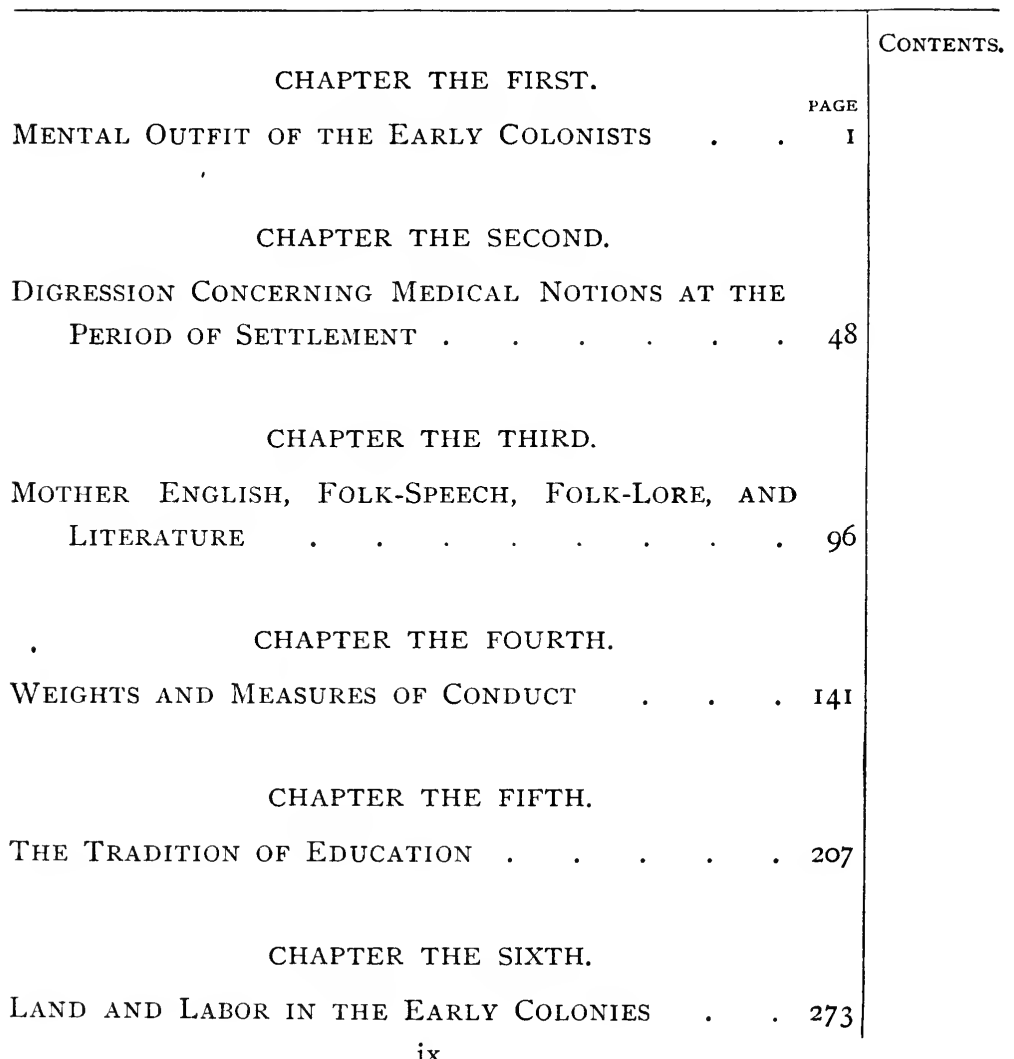

ix 



\section{THE TRANSIT OF CIVILIZATION.}

CHAPTER THE FIRST.

MENTAL OUTFIT OF THE EARLY COLONISTS.

I.

WHAT are loosely spoken of as national characteristics are probably a result not so much of heredity as of controlling traditions. Seminal ideas received in childhood, standards of feeling and thinking and living handed down from one overlapping generation to another, make the man English or French or German in the rudimentary outfit of his mind. A gradual change in fundamental notions produces the difference between the character of a nation at an early epoch and that of the same people in a later age. In taking account of the mental furniture which the early English emigrants carried aboard ship with them, we shall gain a knowledge of what may be called the original investment from which has been developed Anglo-Saxon culture in America. The mother country of the United States was England in the first half of the seventeenth century, or, at most, England before the Revolution of I688. From the English spoken in the days of the Stuart kings came

Chap. I.

The first EnglishAmericans. 


\begin{abstract}
Chap. I. Our primitive speech, and the opinions, prejudices, and modes of thinking of the English in that day lay at the bottom of what intellectual life there was in the colonies. Some seventeenth-century characteristics, long since lost or obscured in England, may yet be recognized in the folk-lore and folkspeech, the superstitions and beliefs of people in America. The number of English who crossed the seas before the middle of the century was above thirty thousand. Those who survived the first rude outset of pioneer life, with their fast-multiplying progeny, numbered probably fifty thousand in 1650 , and this population was about halved between the colonies on the Chesapeake waters and those to the northward of the Dutch settlement on the New England coast. |To these early comers it is due that the speech, the usages, the institutions, and the binding traditions of the United States are English.
\end{abstract}

II.

Milton and

Shakespeare.

In reckoning the mental outfit of the first comers we should only mislead ourselves by recalling the names of Jonson and Shakespeare and the other lights that were shining when the Susan Constant and her two little consorts sailed out of the Thames to bear a company of English people to the James River. Nor will it avail riuch to remember that Milton was a Puritan at the same time with Cotton and Hooker and Winthrop. The emigrants had no considerable part in the 
higher intellectual life of the age; the great artistic ChaP. I. passions of Shakespeare and Milton touched them not at any point. Bacon's contribution to the art of finding truth did not belong to them. $<$ Men may live in the same time without being intellectual contemporaries.>

\section{III.}

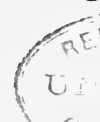

The science that touched the popular imagination in the seventeenth century was astronomy. "God gave to man an upright face that he might view the stars and learn astronomy," according to system.

Wilkin's works, a couplet of the time. As then accepted astronomy was a jumble of the prevalent Ptolemaic theory of the universe with the world at the center, and of the odds and ends of mediæval astrology -moon-signs, zodiac-signs, horoscopes, ominous eclipses followed by devastating fires, and comets presaging disaster and the death of princes, with the mystical doctrine of the dominance of planets over plants, minerals, and diseases. The Copernican system, which essayed to displace the "firmset earth "from that central position in the universe it had so long occupied, made headway slowly. In the interval between the landing of the Jamestown gold hunters and that of the Plymouth Pilgrims, the great Kepler, working in obscurity, developed the three principles which are the foundations of modern astronomy. It was two years before the beginning of the Plymouth settlement that, in poverty and neglect, he wrote: "Fare- 
Chap. I.

Kepler, De Cometis, p. 98.

Ibid., Harmonicus Mundi, 178, 179 .

Note 1 .

Howell's

Letters, vol. iii, ix, and Sir T. Browne's Vulgar Errors, book vi, chap. v.

Note 2.

Note 3. well, Ptolemy! I am turning back to Aristarchus under the lead of Copernicus"; and in the loneliness of his convictions he said in the same year, "My book may well wait a hundred years for a reader, since God himself for six thousand years awaited a discoverer." After Virginia and New England were securely settled, Galileo was imprisoned for demonstrating the earth's motion regardless of the time-honored opinion of Joshua the son of Nun and the indubitable witness of everybody's senses. As the middle of the century approached, one finds Copernicanism spoken of as "the theory that has so stirred all our modern wits." In strictly orthodox circles, in good society, and among the people generally, the sun, the moon, the planets, and the fixed stars continued to revolve round the earth as aforetime to lighten the paths of men or at least to twinkle on them, to lord it over plants and animals, to indicate the nature of diseases, and to foretell to the expert the fortunes of the future. The rhetoric of colonial preachers still turned the universe of fiery lights about the solid earth. In 1666 and afterward one may read between the lines in the non-committal writings of some Harvard mathematicians a possible preference for Copernicanism. Throughout the century the English-American colonists with a few exceptions rested undisturbed in the notion that the center of universal motion was the earth, and that the heavenly bodies were imponderable flames hung up for the convenience of man. 
IV.

The interest in astronomy was mainly pracAstrology. tical; the stars were thought to exert a controlling influence on human affairs. Kepler himself lived in part by casting horoscopes for princes, as Tycho had done before him; (it is by such scullion work that the world in every age contrives to degrade its superior men and dissipate their energies.) John Winthrop, the younger, Grovernor of Connecticut, a fellow of the Royal Society and a man of much learning, as learning was then understood, possessed some of the works on astrology so much esteemed at that time. Among these is a book with astrological figures set one on each page with the lower half of the page blank. These diagrams are for every four minutes of time, and by means of them "any reasonable artist" in such things A Table of the Astrological Houses of the Heaven, I654. " may give judgment of a question." On one page some reasonable artist has essayed to find out, by casting a horoscope, what was the ailment afflictNote 4. ing one Alice Wilkins in 1656. Medicines were administered when the moon was in the proper sign, and the almanacs of the eighteenth century told the farmer to cut his brushwood in certain signs of the zodiac and in the decrease of the moon, that it might not grow again, but to cut firewood in the increase. Timber to last must be cut in the last quarter of the moon. So Tusser, in his Points of Good Husbandry, says, "The moon in the wane Note 5 . gather fruit for to last." The Rev. Jared Elliot, 
CHAP. I. the leading colonial writer on agriculture in the middle of the eighteenth century, shows great respect to the zodiac, and the prosperity of the Pennsylvania German was attributed to his regard for the moon's phases. In many regions to day the moon rules the planting of potatoes, the cutting of hair, and the killing of pigs; and women wean their infants in the proper sign of the zodiac. These are the ragged remnants of the ancient and complicated science of astrology which survived from the middle ages, and which with much other Note 6. strange baggage of the sort crossed the wide seas with the emigrants to America.

Comets and other portents.

Alexander Nowell, Cambridge Almanac, I666.

Note 7 .

Nowell, as above.

\section{V.}

Most people knew little of the complicated mysteries of horoscopes, and they understood less of the jargon of astrology. But the unlearned kept pace with the learned in looking with religious dread upon comets. "Experience Attests and reason Asserts that they have served for sad Prologues to tragical Epilogues." The words are those of perhaps the earliest American writer on astronomy; the opinion was that of the world at large in his time. On the science of prognostication by comets learned men disagreed. "Some," says the writer we have just quoted, "put much trust or vertue in the tail, terming it the Ignomon." Naturally enough a comet "operated most powerfully" on the people to whom it was "vertical" 
-that is to say, over whose heads the body of it CHap. I. passed. Some thought that comets were themselves agents of mischief, drying up the moisture of Nature and thus producing droughts and pestiSpencer, Of Natural Prodigies, lential fevers, and inflaming the anger of princes; 14.

as they were supposed to be in combustion they excited the air to tempests, and thus raised great waves and inundated the earth. The winds driven into caves, and by some means imprisoned in the earth, made the ground quake in their endeavors to get out, said the astrologers. Others believed that they were but a sort of celestial weather signal hung out to give warning of the imminence of calamities ordained by God. Yet others believed that, in the phrase of the time, they were "both effectual and significant." It was noted in New England that when John Cotton, the great ecclesiastical luminary of the first generation, drew near his end, a comet appeared which "went out" soon after the preacher's death. The blight of 1665 , that put an end to the hope of prosperity from wheat-raising in Massachusetts, was heralded by "a great and blazing comet," which, like all portents and omens, lacked definiteness, for it was "accompanied with many sad effects" beside. John Hull, the pine-tree shilling-maker, calls the attention of a correspondent to the comet of 1680 with a pious ejaculation of alarm: "The Lord fit us and you for all his will and pleasure." A protagonist of Puritanism in its decline was Increase

Compare Kepler's De Cometis, 104 , I05. Compare Kepler, as above, 107, Io8.

John Edwards, Cometomania, p. 3,1684 .

Josselyn, Chron. Obs. sub anno. Compare the horoscope of an eclipse in Chauncey's Cambridge, Mass., Almanac for 1663 . Mather. He was a pessimist with a keen relish 
Снар. I. for the supernatural and sensational. Nothing Am.Antiq. delighted him more than calamities past, present, Soc. Trans., iii, 247. Compare I'Ewe's Autobiography, $i$, I23, and Royal MSS. Comm. Rept., xii, p. vii. Acct. book of Sir D. Flening. or potential. The brilliant comet of 1680 was a call from heaven for a man of his genius; he re-enforced it by a sermon entitled "Heaven's Alarm to the World." When two years later another blazing star burst upon a world that had not yet had time to recover its equanimity, Mather proceeded to expound this also in "The Latter Sign Discoursed of," and then followed these with a book, for which he borrowed the title "Kometographia." In this the accidents by land and sea, the disasters of pestilence, famine, war, and assassination, that had ever come trailing after any comet, were once more rehearsed, as they had been rehearsed in other times by other sensational moralists. The notable comet of I680, which set so many watchdogs baying at the sky, alarmed the Dutch dwellers on the upper Hudson, as we may see in a letter dispatched by their usual post, an Indian runner, to New York. In this they mention the "Dreadful comett starr" "with a very Doc. Hist., fyery Tail or Streemer." "Undoubtedly God N. Y., iii, 882. threatens us," is their inference, and they crave permission of superior authority in New York to Note 8. cause "the Domine" to proclaim in the church "a day of fasting and humiliation."

On the eve of Bacon's rebellion in Virginia, in 1676, the people were warned, to no good purpose

The Beginning, Progress, and apparently, by signs in the heavens, in the air, and out of the earth. To a comet "streaming like a 
horse taile westwards" there was added "fflights of pigeons in breadth nigh a quarter of the midhemisphere, and of their length was no visible end." This ought to have been enough to frighten even the easy-going Virginians of that time out of their sins, but comet and pigeons were re-enforced by a third omen-strange swarms of flies " rising out of spigot holes in the earth"; no doubt what are now known as the seventeen-year locusts. (Not only comets, but eclipses, parhelia, or " multiplied suns," and other unusual phenomena were beheld with awe. In auroras the colonists saw swords of flame brandished, and fiery horsemen charging in ghostly battle. There was always the chance that a particularly brilliant display of northern lights might prove an awful forerunner, not of war and famine, but of the combustion of the earth and the crack of doom itself. Rainbows, on the other hand, were recorded with a "Laus Deo." The people of Boston were comforted by a rainbow after the unlucky outcome of an expedition against Port Royal in 1707, but nothing else came of it. The rainbow which raised all hopes at the outset of an expedition, in $\mathrm{I} 7 \mathrm{I} \mathrm{I}$, also played Boston false.

ChaP. I.

Conclusion of Bacon's Rebellion, by T. M., Force, i. Note 9. Compare Evelyn's Diary, i, 264 , and Henry King's sermon at Pavl's Crosse, 1621, p. 15.

Lambert's $\mathrm{New}$ Hz̧ven, 190.

Compare The Rainbow, a sermon at Pavl's Crosse, 1617, by Bourne.

Sewall's Diary, ii, 189, 314, 318.

VI.

From Greek and Roman antiquity down at least to the middle of the seventeenth century no Spontaneous generation. scientific proposition was more universally received than that insects and some birds, fishes, and 
Chap. I. reptiles were generated by putrefaction, or, to turn the proposition round, that all putrefaction produced life. From the bodies of decaying horses came hornets; but kine in decomposition produced honeybees. Ovid says that this was known by experience, and later writers quoted his verses on the subject and saved themselves the necessity of observation. The practical bee-keeper of the seventeenth century did not read the classics, or Gesner or Mouffet, or any of the other innumerable Latin treatises on animal life, but he did look into his hive occasionally, and he knew that a bee came from a "little worm" in the comb. Bees taken from England to Virginia and New England prospered. But the traveler Josselyn entertained the hope that, when the carnivorous animals should have been exterminated, American bees might be produced from dead bullocks, after the approved Note ro. scientific formula. Some kinds of wasps had their origin in the decay of apples and pears; the most superficial observer might find them to his sorrow

Porta, Magia Nat., liber xv, caput iv. issuing from the fruit. Minnows were produced from foam, carp came from putrid slime, the oyster, the nautilus, and other shellfish from different kinds of putrescence mixed sometimes with mud, sometimes combined with the sand of the sea bottom. So far did Nature carry this economy . that even the discarded tails of New England tadpoles were not suffered to go to waste: out of them were formed the water newts, as Josselyn takes pains to explain. Lord Bacon, who floun- 
ders like a stranded leviathan when he seeks to explore the coasts of physical science, suggests that toads come from the corruption of water mixed with mud; to "old snow" he attributes the generation of those red larvæ or "worms" which are yet believed by the unlearned to have "snowed down." A chemist of that day, whose work was reprinted by the Royal Society, says of fermenting bread dough that "unless it were bridled and restrained by ... Artificial Fire it would proceed to vitality and produce worms." It was held in Elizabeth's time, and long before and after, that parasites were bred from the body on which they lived. As late as $1676^{\circ}$, when Bacon, the Virginia rebel, in his last illness found himself obliged to cast his discarded garments directly into the fire, the presence of the parasites was thought to be one of the results of his disease and a divine judgment on him for rebellion, though the case is sufficiently explained by the fact that he had been dwelling in Indian wigwams a few weeks before. The persistence of vitality was held then as the persistence of force is now; "no one living creature corrupts without the production of another," was an accepted maxim. Lord Bacon states it more cautiously: "Briefly, most things putrefied bring forth insects of various names."

VII.

If there was much lack of book learning in the generation of English people that sprung up first

Chap. I.

Bacon's Natural History, passim.

\section{Otto} Tachenius, $\mathrm{His}$ Clavis, 6.

Note II.

Comp.

Tiraboschi, ii, 430 , on the production of fossil trees.

\section{Note 12.}

Migration of birds. 
Chap. I. On American soil, there was some gain in a life in which exigent wants compelled a habit of shrewd observation. For centuries strange theories had prevailed among learned and unlearned regarding the origin of those far-wandering waterfowl whose distant resting places were yet undiscovered. Following the analogy of the accepted theory regarding the production of "insects," including frogs, mice, and snakes, there were those who derived many birds from wood rotting in the water, or from decaying fruits. Others said that some birds grew on trees, and proved it by showing the shells of the nuts from which the bird had emerged. The socalled barnacle goose had been held for centuries to develop from the shellfish barnacle which clings to the bottom of a ship or a water-soaked timber. More than one writer of standing testified to the metamorphosis on the evidence of his own senses, at least he had found a barnacle all befeathered and Note 3. ready to take flight. Easy-going casuists treated the barnacle goose as a fish by virtue of its marine origin, and it was served up to monks and other self-indulgent fasters on Fridays. Such a myth could not be long held in solution by American tradition; barnacle geese were not found, and the unlearned pioneer seeking his meat by prowling along the reedy shores of rivers, ponds, and estuaries with a great fowling piece six or seven feet long in the barrel came to know the life habits of waterfowl better than any of that procession of philosophers who with pedantic learning copied 
incredibilities from one Latin book to another down CHAP. I. the ages. One bit of ornithology of that time crossed the seas, and perhaps by virtue of its absurdity was able to hold its own in America for two hundred years. The annual disappearance of migratory birds and their return in the spring demanded explanation, and in old British folk-lore it was held that such birds were accustomed to lie hid in caves, rocks, and hollow trees. In Cornwall it was reported that swallows out of season Burton's Anat., ii, 2, 3 . had been "found sitting in old deepe Tynneworkes and holes in the Sea Cliffes." Olaus Magnus, a banished Scandinavian bishop living at Carew's Cornwall, I602, fol. Rome, published in the sixteenth century a work learned in form but as full of things unbelievable as the writings of the much-venerated Pliny. He told on the never-to-be-questioned authority of fishermen that they had drawn up torpid swallows in their nets which came to life on warming. $\mathrm{He}$ even gave all the details of their taking refuge for the winter in the clay at the bottom of the river. Once this fond story of the fishermen got itself printed in Latin and authenticated by a bishop, it became a scientific fact. The new notion almost crowded out the old folk-theory of hibernation in caves and holes, and held its own for two centuries, to be reluctantly discarded almost in our time. The revelations of the telescope made the moon seem near, and Bishop Godwin formed a new theory of hibernation in the satellites, which was elaborated by Charles Morton, an Oxford scholar,

Note 15. Morton in Harleiam 
Chap. I.

Miscell., Park's edition, vol. ii, $5^{8 r}$.

But see same suggestion in Godwin's Voyage to the Moon, 1638.

And compare Wilkin's works, 134 .
Other phases of thought regarding animals and plants. whose old age was passed in Massachusetts. He preached a sermon from a text in Jeremiah, from which he deduced a winter home for all kinds of migratory birds among the newly revealed mountains and valleys of the moon. If that were thought too far away for wing travel, Morton was willing to split the difference by suggesting that the earth might have some smaller satellites-little undiscovered gull islands in the heavens for the birds to roost upon. After Morton's death, omnivorous and marvel-loving Cotton Mather appropriated this hypothesis as a piece of flotsam, and wrote a letter to the Royal Society in which he suggested that the prodigious flights of pigeons in the colonies rendered probable the existence of an unseen, nearat-hand satellite, from which came these myriads of birds, and to which they were wont to retreat again. But the English colonists who touched elbows with Nature, and had larger opportunities for observation than their island ancestors, came to accept the annual migration of the disappearing birds before the middle of the eighteenth century. There were, however, learned pundits in Philadelphia as late as I 800, who followed Olaus in winter. ing their swallows in the bottoms of the rivers.

VIII.

Classification, which is at once the result of knowledge and an instrument of investigation, was infantile and unstable even among the learned. 
Fishes, including, of course, sea mammals, had been divided into round and long; to these Harrison adds shelled fishes and legged fishes. Popular classification is always rough, but in that day nobody held firmly to the cardinal division of the vertebrate animals. The beaver and otter were even divided transversely in classification; their hind quarters were counted with the fishes. In ecclesiastical regulations it was not always thought worth while to make two bites of a beaver; Lorrainers and Savoyards, as well as Canadian woodsmen, ate freely of his flesh on fish days, making sure that the meat of so aquatic an animal with so flat a tail could not be flesh. The interest in animal life was unscientific, being mainly an interest in the marvelous stories of the basilisk hatched from a cock's egg brooded by a toad, of the unicorn with a horn eight or ten feet long growing out of his head, of the salamander that endured the fire, of the phœnix that lived five hundred years, of the common hare that changed sex in alternate years, of men that were metamorphosed into wolves in Ireland, of wolves that struck men dumb by seeing them first, of swans that sing before dying, and so on and on. Wonders were not wanting among American animals; the unicorn was observed on the Hudson, and many half-human creatures, reported by early voyagers, dwelt along the seacoast from Cape Ann eastward. Sometimes these were seen at night dancing in groups about a fire on the shore; one daring Triton swimming in Casco Bay

CHAP. 1.

Holinshed, i, 377 .

Russell's Boke of Nurture, Early English Text Society, v, I53, and note from Topsell. Salmon's English Physician, 324 .

Harrison, Holinsh., i, 379. On Unicorns, Brown's Travels, in Harris Voyages, ii, 524. Ray in same, 554. Hakewill's Apologie, "Of divers opinions justly suspected though commonly received," lib. c, I, sect. 5 . Two Voyages, 25. 


\section{Chap. I.}

Compare

Browne's

Vulgar

Errors gen-

erally and

Shake-

speare in

many

places.
Comp.

Sewall's

Diary, ii, 493.

The world invisible. made bold to grasp the side of a canoe and got his hand lopped off with a hatchet. Narrating these occurrences, Josselyn meditates that "there are many stranger things in the world than are to be seen between London and Stanes." We are accustomed to see popular credulity controlled by scientific skepticism, but in the seventeenth century the learned looked for scientific knowledge primarily in the writings of the ancients, sacred and profane, and devoured most of the atrocious stories accumulated by Pliny, "the greatest gull of antiquity." When modern light began to dawn and science tried to observe, it was not mainly the ordinary and the regular that were noted; members of the new Royal Society and others thought to learn from the monstrosities and marvels; New England ministers acted as soothsayers and expounded the hidden meaning of monstrous births, and even played showmen to exhibit these ghastly messages from the Almighty.

IX.

The world invisible as conceived in every age is a reflection of the familiar material world; the image is often inverted: it may be exaggerated, glorified, distorted, but it is still their own old world mirrored in the clouds of heaven. Even the love of rank and ostentation in the seventeenth century-the snobbery of the age-projected itself into heavenly arrangements. In a day when idle 
serving men stood about the halls of a country ChaP. I. gentleman merely to lend dignity to the master, when one no greater than a high sheriff thought it unfit to perform his functions without a squad of liveried retainers at his heels, when a bishop in Christian humility rode about with sometimes a hundred and fifty horsemen clanking after him, and when kingly state was multitudinous in proportion, the majesty of Almighty God required myriads of attendants. Milton thinks thus of God:

\section{His State}

Is Kingly. Thousands at his bidding speed And post o'er Land and Ocean without rest.

And the prose of Bishop Hall is almost as lofty as Milton's verse, when it contemplates "those next-to-infinite numbers of mighty and majestical spirits, wherewith the great God of heaven hath furnished his throne and footstool." Human arithmetic had no terms by which to tell the number of those who "are numerable only to God who made them." The uncountable angels were employed in keeping the universe in motion, as many eminent writers knew partly by intuition, but also by metaphysical demonstration. The busy angels turned round the crystalline spheres from the outer primum mobile, just this side the immovable abode of God, to the nethermost of all that carried the moon about in her lagging revolutions. Besides this duty of keeping the lights The Invisible World, ed. 1659 , p. 15. As above, p. 18.

The good angels.

Digby's Peripateticall Institutions, $362,398$. Hakewill's Apologie, $85,86$. of heaven burning and turning, "these mighty 
CHap. I. angels" produced those "strange concussations of the earth" which are so alarming and "direfull prodigies in the skie," about which it was not Hall's deemed safe to speculate. Hall relates that one Invisible IVorld, 39, and

passim.

Increase Mather's Illustrious Providences.

The evil angels.

Note 16. philosopher was stricken dead for venturing to reason about thunderstorms. It was angelic agency that caused a corpse, in that believing age, to bleed when touched by the guilty hand of the murderer. Angels gave warnings and revelations by dreams, by mental impressions and by apparitions; and they even fought for men against the spirits of the underworld. Of such stuff as this the great Puritan poet wrought the splendid fabric of his epic. To contemporary readers Paradise Lost had as much of history as of poetry. IIt was an imaginative rendering of the picturesque mythology of the seventeenth century, a mythology destined to grow dim in the gray morning light of the critical century that followed.

\section{$\mathrm{x}$.}

The American settlers lived in a different world from that which they had left in England, and their conceptions of the invisible could not escape modification. Far removed from the ostentatious conventions of the old civilization, the minds of the colonists could no longer form vivid pictures of heavenly retinues. One finds few allusions to angelic agency in their writings; thunderbolts which Bishop Hall, "the English Seneca," as he 
was called, ascribes to good angels, Cotton Mather, the New England Seneca, will have to be the work of devils; on this hypothesis he easily explains the disproportionate number of churches that suffered from lightning. The popular belief of the time in the active meddling of evil spirits was not weakened by a life passed in coast settlements, between a wide and wild sea and an impenetrable forest filled with beasts and devilworshipers. Diabolical disturbances occurred rather early in all the colonies, and they were particularly rife in New England, where the imagination was set on edge by theological speculation. In I637 Jane Hawkins, the Boston midwife and dispenser of quackery oil of mandrakes, was diligently examined on suspicion of familiarity with the devil. Eight years later a man from Virginia, reported to have skill in necromancy, was "blown up" in Boston Harbor, and strange to say it was accounted a marvel that he could never afterward be found. Yet more diabolical was it that men in fiery shapes, or "fire in the shape of men," walked the water near where the ship had exploded. In the settlement on the Connecticut devils were particularly active. Hartford, Stratford, Fairfield, and New Haven had witch trials, and in some instances the ordeal of swimming the witch to see whether she could float was resorted to. Springfield was accounted "infamous by reason of the witches there," as the traveler Josselyn tells us. More than one Long Island town had its shallows

Chap. I.

Cotton's Way of the Churches Cleared, 91. Savage's Winthrop, i, 313, 316, ii, IO, II. Mass. Rec., I2, March, I637.

Winthrop, ii, 185 . Hutch. Papers, I36.

Increase Mather's Providences, 9699, and other authorities.

Comp. Mass. Rec., iii, 295, 347. Hutch. Mass., i, I 79.

Wonderworking Providences, iii, 2 . S. Side Signal, Nov. 13, I880. 
Chap. I.

Barber's

N. Y.

Coll., 462.

Mass. Rec.,

iii, 123.

Letters of

Mission-

aries, $9 x$.

Md. Council Proceedings, $306-$ 308 .

Comp.

Gatford's

Public

Good, 12, where is a loose statement of same fact.

Comp.,

e. g.,

Ridgely's

Annals of

Annapolis, $5^{8} \mathrm{ff}$. and others.

Witchcraft.

Note 17.

Cranmer's Articles of Visitation, 2. Edw. VI, Sparrow's Coll., 3r. stirred by witchcraft accusations. Boston brought its first witch to trial in 1648 , and in 1656 the wife of one of the magistrates was "hanged for a witch only for having more wit than her neighbors," as was said at the time. In 1654 a shipmaster sailing with emigrants to Maryland encountered two months of stormy weather, such weather as only "the malevolence of witches" could get up. The crew selected a little old woman of suitable appearance, one Mary Lee, whom they examined "with strictest scrutiny, guilty or not guilty." The poor old body was hanged "out of hand," and all her possessions were huddled into the sea with her, but the hungry tempest would not be quieted by the hideous sacrifice. There were sporadic witch excitements sooner or later in nearly every colony; miniature reflections of what was passing at the time in Europe.

\section{XI.}

The ancient belief in witchcraft, though never extinct, passed through a sort of renascence in the religious excitements of the sixteenth century. As early as , 1548 newborn Protestant zeal against superstition began to attack all kinds of sorcery, and there was also opposition to various popular superstitions in Catholic countries. The charms by which women sought to mitigate the sorrows of childbearing were special subjects of ecclesiastical inquisition in England in the first year of Elizabeth's reign. The tendency of this was to make a 
witch of every midwife and wise woman who encouraged her patients by little quackeries. The trial of a supposed witch by weighing her wizened form in the balances against the huge church Bible bound in heavy boards with metal clasps, or by tying her thumbs and her toes together crosswise to see whether she would float when put into the water, attracted a concourse of people and spread abroad the horrible superstition. "Swimming witches" became a favorite amusement of the brutal populace. "Our Countrey people," says an English writer in 1718, "are still as fond of it as they are of Baiting a Bear or a Bull." The notoriety and outcry served for a sort of devil's advertisement; the afflicted were everywhere set to brooding on the probability that some malicious neighbor or some doted old woman of uncanny aspect had laid them under a spell. The attempt to put down witchery by the infliction of the death penalty served to breed new alarms, new accusations, and fresh executions. In the time of the civil war and the Commonwealth there were infectious witch panics in England. In Essex and Sussex alone two hundred persons were prosecuted for witchcraft, and half of them were executed. Medical skill was dangerous in a time of suspicion. Meric Casaubon saw a clever woman doctor driven from a town because she had benefited a lunatic patient. It was evident to the populace that nothing less than sorcery could relieve a demoniac. In I646 James Howell wrote: "There have been

Chap. I.

But compare Reprouacion de las Superstitiones, by P. Liruelo, of Salamanca, 1547, and others. Art. Visitation, I Eliz., Sparrow's Coll., I80. Note 18.

Fr. Hutchinson, Hist. Essay on Witchcr., I37, 138 .

Casaubon's Enthusiasme, 1656, p. I00.

Familiar Letters, 398. 
ChaP. I.

Commentaire sur Beccaria, ix.

Descended from hobgoblins. more witches Arraign'd and Executed heer lately than ever were in this Island since the Creation." "All the tribunals of Christian Europe resounded with such condemnations," says Voltaire of this period. The poor Turks had never a witch or demoniac among them, a proof positive that their religion was false; the devil sparing his own. It was estimated, on the other hand, that the judges of Christian lands had sent more than a hundred thousand people to death on the gallows or at the stake for the crime of witchcraft.

\section{XII.}

The classic dignity of Milton's evil angels, when marshaled "in battailous aspect," is the work of the poet. The sprites of popular fancy in that age were groveling and grotesque. They made silly contracts with doting crones whom they persuaded to write their names with their own blood in a book, and that without any valuable consideration; they held burlesque religious exercises and dug up dead men's bones to enchant with. They were of the sort that masqueraded as dogs and cats, and hares and toads. They haunted houses for the mere fun of terrifying the inmates; they took possession of hysterical people and talked nonsense from their lips, and they tangled the manes of horses in the night for mere wanton deviltry. The antipathies of these demons were equally incomprehensible. They could be frightened away by 
hanging up lucky stones with natural holes in them, or discarded horseshoes, or better still by burying "witch-jugs" full of horseshoe nails under a threshold, or by the hanging up of fresh bays about a house. They were sometimes known to the witches who were their familiars by such names as Pluck, Vinegar Tom, Catch, Hardname, Jarmara, Elemauzer, Pyewacket, Peckin-theCrown, and Smack. Sprites like these are not primarily the offspring of theological speculation; they resemble the gnomes, trolls, and brownies, the Hudekins, Robin Goodfellows, and Friar Rushs of the tales and ballads. They have floated down from ancient heathen times on the stream of nursery and fireside folk-lore. But they had ceased to be regarded with awed amusement as were their progenitors the gnomes and fairies. They had come to be denounced from pulpits and accused of grewsome and horrible acts suited to their new position as Christian devils.

\section{XIII.}

This grotesque superstition could not be disentangled from the creed of the time. Jurists like the astute Coke and the conscientious Sir Matthew Hale, and even such philosophers as Lord Bacon and Sir Thomas Browne, were helpless to rid themselves of it. It was part of what we may call the fixed intellect of the age. The people who first saw on the stage Shakespeare's "secret, black,

ChaP. I.

Notes and Queries, vol. vi, No. I 5 I, p. 27 I. Mather's

Providences, chap. v.

Retrospective Review, v, I22. Hutch., Hist. Essay on Witchcraft, ${ }_{7} 7 \mathrm{I} 8$, p. 103.

See Wright's Literature and Superstition of England, vol. ii, essay $x$; and Comp. Douce's Shakespeare, i, 382-394.

Realism of devils. See A Tryal of Witches, r654, before Sir Matthew Hale, especially Sir T. Browne's 
Chap. I.

testimony, p. 4I, and Hale's Charge, 55,56 .

Note 19.

Hall's

Cases of

Conscience, Dec. 3, Case I.
Illustrious

Providences, ed. I856, p. 120.

See Upham in many places. and midnight hags" were no doubt touched with a ghastlier horror than the æsthetic shudder this apparition affords in later times, for the diabolical dance of witches concocting infernal spells had then the force of daring realism. "That there are evill spirits," says Bishop Hall, "is no lesse certaine then that there are men.... That evill spirits have given certaine proofes of their presence with men, both in visible apparitions and in the possessions of places and bodies, is no lesse manifest then that we have soules." But God had "bound up the evill Angels in chaines of darknesse." This was to restrain them from frightening God's "weake creatures" by "those frequent and horrible appearances which they would otherwise make." It was God's pleasure sometimes to "loosen or lengthen" the chains and permit these diabolonians "to exhibit themselves under some assumed shapes unto men," which gives the eminent casuist occasion to discuss "what our deportment should be" when a devil whose chain has been temporarily slackened "exhibits" himself to us. This very materialistic conception of the devils in chains like mastiffs is not peculiar to Hall. It was a trait of thought at the time. It occurs more than once in Increase Mather, as "the Lord doth sometimes lengthen the chain which the infernal lions are bound fast in," and so on. In the trials at Salem we repeatedly come upon the expression in a grossly literal sensc. 


\section{XIV.}

The notion of house-haunting demons-a superstition the most nearly a survival from the days of the elves and brownies-crossed the sea with the early emigrants. One such spirit in Newbury in New Hampshire, in 1679 , threw sticks and stones on the roof of the house, lifted up the bedstead from the floor, threw the bedstaff out the window, threw a cat at the mistress of the house and beat the goodman over the head with a broom, made the pole on which the kettles were hung to dance up and down in the chimney, tossed a potlid into the fire, set a chair in the middle of the table when dinner was served, seasoned the victuals with ashes, filled a pair of shoes with hot ashes, ran away with an inkhorn, threw a ladder against a door, and put an awl into the bed. It played a hundred other lively pranks until "it pleased God to shorten the chain of this wicked demon." While the chain was shortening the disheartened demon was heard to cry six times over, "Alas! me knock no more!" In Hartford, in 1683 , there was a gentle devil with a taste for flinging corncobs through the windows and down the chimney. Stones and sticks were sometimes thrown, but softly so as to do no serious harm. When the occupant of the haunted house returned to its owner a chest of clothes unjustly detained, no more corncobs were thrown. In Portsmouth it rained stones outdoors and in at the house of George Walton, and, what is curi- 
CHAP. I.

Comp. burning of Bingen by devils, Inc. Mather's Cases of Conscience, 18, and other stories, ibid., passim.

Note 20.

Demoniacal possession. ous, some of these stones were hot. Glass windows were shattered, and a stirrup iron traveled off on its own motion without horse or rider and was never again seen. Sometimes a hollow whistling sound was heard. This whistling devil amused himself like a true brownie by hanging the haycocks up in the trees and decorating the kitchen "all up and down" with wisps of hay. Sometimes the chains were sufficiently lengthened for a New England demon to become visible. One appeared as a "black-a-moor child," another as a woman clad in green safeguard, short blue cloak, and white cap. Once the black cat, so dear to tradition, appeared and was shot at; again the head of a man was seen swimming through the water, followed a little way off by the tail of a white cat. These American devils with their undiabolical sense of humor have at least a family likeness to the mischievous elves, pucks, brownies, and other "tricksy sprites" with which the English imagination peopled lonesome glens and the dark corners of their houses in primitive times. Whether the later demons were creatures of excited fancy or of imposture, or both, they were cast in molds supplied by ancient tradition.

\section{XV.}

The phenomena known in later times as hys. teria, and as mesmerism and hypnotism, were not yet recognized to be due to natural causes. The infinitely delicate shadings by which mental sanity 
passes without any line of demarcation into madChap. I. ness could not then be imagined. A belief in demoniacal possession was almost unavoidable. That men and women might be "obsessed with cacodemons," in the pedantic phrase of the time, had the sanction of the ages, of religion, and of science Inc. Mather, Cases of Conscience concerning Witchcraft, $3 \mathbf{I}$. itself. Only the most hardy intellects ventured to question an opinion so well supported.

In the Massachusetts town of Groton, in $167 \mathrm{I}$, occurred a case of well-defined hysteria. The village minister naturally concluded that the violent contortions and "ravings" of the patient, Elizabeth Knap, "represented a dark resemblance to hellish torments." When in one of her fits she cried out, "What cheer, old man?" to whom could she be speaking if not to the devil? Like many other hysterical sufferers, she was susceptible to hypnotic suggestion, and in answer to leading questions she was able to remember having made the compact with Satan always presupposed in such cases. This in saner moments she retracted, as she did also accusations of witchcraft made against others in reply to probing inquiries. She once described to the shuddering bystanders a witch visible to her at that moment, having a dog's body and a woman's head, running through the room and climbing up the chimney. Good Parson Willard and others present found all this so exciting that they, though unable to see the apparition, could detect the imprint of a dog's foot in the clay daubing of the

S. A. Green's Groton in Witchcraft Times. chimney. 
CHAP. I.

Agency of religious fervor.

Glanvill's Sadducisismus

Triumphatus, and I. Mather's

Providences, passim. Comp. Sprengel's Geschichte der Arzneikunde, edition 1803 ,

iv, $34 \mathrm{I}$, note 4 .
XVI.

Worst element of all in this delusion was the mistaken zeal of the clergy. Ministers of differing creeds agreed in believing that the palpable evidences of spiritual existence afforded by witchcraft might serve to vanquish the ever-present skepticism regarding the supernatural. Squalid tales gathered at witch trials, many of them foul and revolting as well as unbelievable, were disseminated as religious reading, in hope that they might prove a means of grace by revulsion. If any man had the courage to question the supernatural character of these disgusting apparitions, he found himself gazetted in the authoritative writings of eminent divines as a Sadducee, a patron of witches, and a witch advocate; if he took a neutral position for safety, averring the existence of witchcraft but denying the possibility of proving it in particular cases, he was dubbed a "nullibist." This in America as well as in England. A new case of witchcraft did not excite pity, but something like exultation; the Sadducees were again confounded. The Puritan ram's horn of Increase Mather answered across the seas to the bugle of Glanvill, chaplain in ordinary to Charles II, and late in the century the good Richard Baxter himself re-echoed Cotton Mather's shout of victory amid the horrors of the judicial massacre at Salem. Reports of continental witch trials were translated for the edification of Englishmen. By this array of frightful diabolism it was 
hoped that the swelling tide of gross immorality Chap. I. might be checked and religion promoted, for the appeal of religion in that day was to fear rather than to aspiration; the peril of trying to kindle altar fires with embers from hell was not understood.

XVII.

Salem village, an outlying suburb, two or three miles from Salem proper, was almost a frontier The Salem Witchtown in 1692. Men still wore buckskin breeches and hats with a brim narrow in front and long behind. Wolves, bears, and catamounts were trapped. Some of the settlers had participated in the desperate battle at the Narragansetts' town sixteen years before. The sword and the rapier were still worn at the side, the fowling piece six and seven feet in length was in use. Men had been killed by the Indians in the bounds of Salem within three years. Education was generally neglected; even men of substance were sometimes unable to write. The old patriarchs who had made the settlement had just died off; the community had lost its steadfast guides. New clergymen had come in and new magistrates, not with the education of England, but with the scantier training of New England-a training in which the felling axe was more important than the Latin grammar. The new clergy, men of the second and third generations, were, with a few exceptions, profoundly impressed with the necessity of believcraft. 
Снат. I. Ing anything ghostly or horrible; the supernatural was the basis of their piety. Increase Mather, the bishop by brevet of New England, had published books on the ominous eclipses of 1680 and 1682 , and another in 1686 on Illustrious Providences, which was a storehouse of those dragons' teeth that bore such ample fruit in 1692 . His abler but less judicious son, Cotton, had issued a book on "Memorable Providences relating to witchcraft and Possessions." It had come to a second edition in the very year before the horrors of Salem.

The village of Salem had the elements needed for a witchcraft mania-a quarrel between minister and people; a circle of young girls from eleven to twenty, including some who worked as helps, who met at the minister's house and practiced together folk-sorcery and that kind of divining that has been the amusement of such for ages. These girls soon began to manifest symptoms of hysteria and hypnotism; one or two married women also had "fits" in sympathy with them. A doctor called to attend them decided that they were afflicted by "an evil hand." There was some heartless and heedless imposture, no doubt, in what followed, but there was also much of selfdeception.

The glimpses of the infernal world that we get in Salem are highly incredible. The witches say prayers to a tall black man with a high-crowned hat-always with a high-crowned hat. They ride on sticks and poles, sometimes they are on brooms, 
and sometimes three are on one pole. One relates that a pole carrying two broke, but, by holding fast to the one in front of her, the witch got safe to her destination. The witches fondle yellow birds, suckling them between their fingers, and one day a girl cries out in meeting that a yellow bird sits on the minister's hat as it hangs on a pin on the pulpit. The witch usually sits on the great crossbeam of the meetinghouse, fondling the yellow bird. One man was seen to nurse two black pigs at his breasts. Sometimes a hog, sometimes a black dog, appears and says, "Serve me." Then the dog or pig "looks like a man," and this man has a yellow bird. Cats naturally abound, white cats and red cats and cats without color. Once a man struck with a rapier at a place designated by one of the girls, and she declared the cat dead and the floor to be all covered with blood. But no one else saw it. This is probably hypnotism, hardly imposture. A great mass of such inconsequent and paltry foolery was believed, not alone by owlblasted children, but by Stoughton and the other judges, and by pious Samuel Sewall himself, more's the pity! Where is the motive? What prompted the most eminent Christians and leading citizens to prefer so base a life-companions to cats and dogs and devils? Why did this torture of innocent children, this mischief-working witchcraft with endless perdition at the tail of it, give pleasure to rational creatures? The court never once thought to ask. 
The trial scenes were perdition. The "afflicted children" screamed, went into spasms, shouted, charged the prisoners with torturing them, and their apparent torments were frightful. They laid to the charge of the accused unheard-of deviltries, such as the killing of wives long dead, attempting to choke aged grandparents, and what not besides. Husbands in some instances turned against wives, in others they adhered to them, were accused themselves, and died with them.

The trials were accompanied by great cruelties. Officers of the law were allowed to plunder the estates of the accused of all movable property. The prisoners had to pay their jail expenses, and many families were utterly impoverished. Prisoners were cast into the dungeon and were "fettered." Goodman Hutchinson complained of certain prisoners for tormenting his wife; additional fetters were put on them, after which Mrs. Hutchinson was "tolerable well." Some were tortured to make them confess; lads were laid neck and heels until the blood gushed from their noses. These were accredited practices at the time. Several died in prison.

The very skill of the accused was against them. One very neat woman walked miles over dirty roads without showing any mud. "I scorn to be drabbled," she said, and she was hanged for her cleanliness. George Burroughs, the minister, was a strong man, much addicted to gymnastics. He carried barrels of cider by inserting his fingers into 
the bunghole, and held a seven-foot gun at arm's ChAP. I. length. He was the devil's man, away with him to the gallows! The first people in the colony became involved. Twenty in all were executed, four or five at a time. Their bodies were ignominiously thrust into holes at the place where they were executed and were scantly covered.

There were brave men and women among them. Giles Corey, an eccentric old man, had at first signed an affidavit of uncertainty about his wife, a woman of piety, and, strange to say, an entire unbeliever in witchcraft. Two of his sonsin-law turned against her, two were for her. But when old Giles was accused he stiffened his neck. He would save his property, which was considerable and might be compromised; he would will it all to his two faithful sons-in-law. He would prove his steadfastness. He made a will, perfect in every part, giving his property to the sons-inlaw, and then totally refused to plead and was slowly pressed to death. The constancy of the old man did much to overthrow the partisans of witchcraft. Joseph Putnam, a young man of twenty-two, declared his detestation of the doctrine. He kept some one of his horses bridled and saddled for six months. He armed all his family, and it was understood that he must be taken, if taken at all, pistol in hand. When the mania was at its height he refused to have his child baptized in the village, but carried it to Salem. 
CHAP. I.

The excitement had risen with every arrest. More than fifty badgered souls had confessed that they were witches. Some had fled the country. But the wide extent of the accusations produced a change in the minds of the people. They knew not who would be struck at next. The governor, at length, refused to call the special court together, and after a tedious confinement a hundred and fifty were released by proclamation. The population of Salem had decreased, its business had suffered, and perhaps it never recovered its prosperity. Slowly the people got over the delusion and came to realize the incalculable and irretrievable harm that had been wrought. Judge Sewall, at a general fast, handed up to the minister to be read a humble confession, and stood while it was read. He annually kept a private day of humiliation. Honor to his memory! The twelve jurymen also signed an affecting paper asking to be forgiven. Cotton Mather, who had been very conspicuous and had published a book about it, never acknowledged himself wrong in this or any other matter. From the time it became unpopular he speaks of the witchcraft trials in a far-away manner, as if they were wholly the work of some one else. He was never forgiven, and probably never ought to have been.

Note 2 r.

The revulsion was complete. No witches were tried or hanged or "swimmed" in America after the Salem trials. In half a lifetime more the ardor of the English people visibly abated, and few witches were thereafter arrested in England. 


\section{ELUCIDATIONS.}

In 1638 there was published anonymously the voyage of Dom ngo Gonzales to the moon, in which clever bit Godwin, Bishop of Hereford, anticipated some of the traits of Bergerac's A Voyage to the Moon, of Robinson Crusoe, of Gulliver's Travels, of Peter Wilkins and his Flying Wife, and even of Mr. Stockton's Negative Gravity, to say nothing of Hans Pfaal, in which Poe imitated the story with purpose aforethought-and I know not how many tales besides. But what interests us most is that under cover of a fantastic story, said to have been written about 1603 , the bishop declares himself on the side of Copernicus and Galileo, and suggests the doctrine of gravity propounded by Newton at a later period. On time of writing Antony à Wood, Ath. Oxon., i, 582, second edition, Hallam, part iii, chapter vii, Wilkins, Fishop of Chester, an able mathematician, published anonymously in 1640 two treatises, the first to prove that " the moon may be a world," the second arguing that the earth is a planet. They are reprinted in his mathematical works. See a character of Willins in the life of Seth, Bishop of Salisbury, 27. As late as I660 Peacham's Compleat Gentleman gives an account of the ancient s.ystem of Ptolemy, and does not think it worth while to inform the polite reader that any other notion of the universe had ever been suggested.

George Sandys, who died in 1643 , and who was the poet secretary to the Virginia colony, wrote in his old age of the firmament .

With such undiscerned swiftness hurl'd

About the steadfast center of the world,

Against whose rapid course the restless sun

And wand'ring flames in varied motions run.

Which heat, light, life infuse, time, night and day

Distinguish, in our human bodies sway, etc.

In 1666 Samuel Danforth published, in Cambridge, Mass., a book entitled An Astronomical Description of the Late Comet or Blazing Star. It was reprinted in London. He maintained that its orbit was elliptical, and that its center of motion was not the earth-a long stride toward Copernicus. He proved that it was a celestial luminary by its size, its parallax, its duration, its visibility in many countries, etc., and concludes that it is a "planetick or erratick body." It was observed without instruments. Alex-

CHAP. I.

Note I, page 4 .

Note 2, page 4. 
CHAP. I. ander Nowell, a Harvard graduate of the previous year, published an almanac in which he argues in opposition to the old notion that planets have no light of their own, and in 1667 he issued a little booklet which I have not seen, Josselyn's Voyages to New England, 47-52, if indeed Josselyn has not confused the almanac with an imaginary booklet. In 1674 a thesis for the master's degree at Harvard affirmed the old opinion that the starry heavens were of fire, but in 1688 it was maintained that the material of the celestial and terrestrial bodies were the same, which may have been as far in the direction of the new astronomy as it was safe to go at that time. Young's Subjects for Master's Degree, 15. On the notion of the heavenly bodies as free from gravitation, compare Hakewill's Apologie, 1630: "They are not subject to the qualities of heat and cold, or drought and moisture, nor yet to weight and lightnesse which arise from those qualities," p. 73. "Light bodies naturally moove vpward and heavy downwarde, that which is neither light nor heavy is rather disposed to a circular motion," etc., p. 86 . See a passage on pp. 85 and 86 on the various hypotheses of celestial motion. In the entire discussion this English divine, learned in the lore of the day, does not think it worth while to mention Copernicus or Tycho, or either of his own great contemporaries, Kepler or Galileo. The Copernican theory was a stone rejected of the builders.

Note 4 , page 5 .

The calculation is based on the "decumbiture or the time when sickness envaded or ceased [seized] on Allice Wilkins," which was January II, 1656, at 6 P. M. This is the only American case of which I know any record. "That ye pty is really sick is evident in yt the lord of ye ascendant is not in essential dignity, but in his detriment $\&$ in ye six house and is in configuration with bad planets, thein freindly aspects which signifye the disease will not bee exceeding greate. And in yt there is a melancholly signe in the six house, and his lord of a melancholly nature, we may judge the rise of the desease to proceed from melancholly, and all so choler doth much abound and the bloud corrupted with melancholly humorus the pts affected are these, viz., the heart and back." So runs on our astrologer until " the stone of the kidneys" is somewhat suddenly hit upon as the disease. The book is in the Winthrop collection in the New York Society Library. There was formerly care taken to administer medicine when the "sign came right" ; laxatives were to be given when the moon was in Libra or other favorable constellations, and the 
approach of Saturn was to be guarded against because that maChap. I. lign planet congealed the humors and remedies in the body. Aristotelis Secretum Secretorum, folio xxv, I 528, in Latin black letter. This work, attributed to Aristotle, was often printed in Latin, and was translated into English in the reign of Henry VIII.

Porta in liber, xiv, caput iii, under the title Vt aves tenesNote 5 , cant, explains that meat exposed to the rays of the moon became page 5 . more tender, this tenderness being but a form of putrefaction. So wood more rapidly decays, and fruits mature, in the moonshine.

Archdeacon Hakewill, in his Apologie, traces the regulation Note 6, of farm processes by the changes of the moon to Pliny and Aristotle, and even to Hesiod. Hakewill mentions the moon's supposed influence on lunatics, the selenite, a stone whose light is said to wax and wane with the moon, the tides, etc. "The physitian in opening a veine hath ever an eie to the sign then raigning." Edition of 1630, pp. $7 \mathrm{I}$ and 72. "Mr. Camden observes that the towne of Shrewesbery suffered twice most grievous losse of l.fe by fire within the compasse of fiftie years vpon two severall eclypses of the sunne in Aries," p. I5I. Hakewill thinks the s.tars " not signes only," but " causes of immoderate cold or heat, drought or moysture, lightning, thunder, raging windes, inundations, earthquakes, and consequently of famine and pestilence " ; but he admits that "the prognostication ... is very vncertane." The popularity of astrology in the seventeenth century is manifest from the frequent references to it, and from the great number of books published on the subject. The doctrine of correspondence connected astrology closely with every other science. Some of the clergy opposed it. See, for example, Henry King's sermon at St. Paul's, I62 I, p. 25, and, earlier, Hall's Satires. liber ii, satire vii. As early as $\mathbf{1} 577$, indeed, the Bishop of Winchester, writing to Sir W. More, says that he would gladly know the opinion of astrologers relative to the "tayled star." He would " gladly learn what they find in the lower heavens, for to the higher they never will ascend." Losely MSS., 491. The reader may compare Hakewill's Apologie, I26, I28, edition of I630. The troublous time of the great rebellion led many in England to see signs in the heavens, and brought about an increase of interest in astrology. The opinions prevailing more and more among the best-informed men of the time are set forth 
Chap. I.

Note 7, page 6.

Note 8 , page 8 . briefly and with much moderation in the Spanish work Magia Natural, o Ciencia de Filosofia Ocvlta, written by Castrillo, a Jesuit, and published 1649. See especially chapter xi of the first part, in which Castrillo concludes that "the movements or aspects of the heavens are not certain indications of free acts and contingent consequences, for these are subject to changes independently of them." Folio 17 , reverse.

These words are attributed to Danforth by Josselyn. Danforth's book on the comet of I666 I have not seen. But I find the passage in Nowell's Cambridge Almanac of 1666, the date of the London edition of Danforth. I have therefore credited them to Nowell.

The discussion of the significance of comets by Kepler in his De Cometis, published in 1619, is an interesting example of a great mind deriding the vulgar astrological notions on the subject, and yet feeling a necessity for some rational explanation of the generally believed connection between comets and disasters. His explanation seems to the modern mind insufficient enough, and he was himself little content with it. "Haec igitur est, si vlla est, naturalis connexio horum euentuum cum Cometa." It would have been but a short step from this to the rejection of calamitous comets, head and tail. The works that treat of the ominous character of comets were a considerable element in the literature of Europe in the seventeenth century. Christiani, in 1633 , declares that man but a stranger in history who denies that God threatens this "wornout world" by means of dreadful comets, multiplied by suns, and other portentous phenomena. The passage is quoted by Voëtius in his Excertatio de Prognosticus Cometarum, I665. Voëtius lays stress on the universal consent both of learned and vulgar to the bad reputation of comets. Dr. John Spencer, afterward Dean of Ely, protested in a learned and liberal little book that comets were not ominous. In this Discourse concerning Prodigies, 1663, this large-minded divine maintains that God has no use for "any such winding and squint-ey'd Oracles" as those of the heathen. He aptly characterizes the traditionary science of that day in a single phrase: "A Series of many Assertours which (like persons in the dark) shut their eyes and take care onely to hold fast by those which went before them." First edition, p. 72. The ridicule in Boileau's Arrêt Burlesque in 167 I shows that the belief in such portents was waning. Euvres de Boileau, edition of I821, iii, 120. The notable comet of 1680 , which brought the English 
colonists to the point of talking about reforming their morals, brought forth Pierre Bayle's work, into which he built a great many other thlngs besides comets. It also awakened discussion in Mexico. Sigurenza y Gorgora, a Mexican priest, published in 1681 his Manifesto filosofico contra los Cometas, in which he opposed the popular dread.

The larva of this insect, known to us as the army worm, was regarded with similar wonder in Massachusetts. In the probably unique copy of a New England almanac for 1649, preserved in the New York Public Library, an appearance of them in 1646 is set down in the chronology of marvelous events, as is also a great flight of pigeons. The conventional bit of verse at the foot of one of the pages is devoted to these omens, ending with the couplet :

But suddenly to flight they all prepare,

No man knows how unless it was by pray'r.

There will soon be left no living eyewitness of the flights of wild pigeons which were seen in the colonies and continued to occur occasionally in the Ohio Valley a little later than the middle of the nineteenth century. Let me here record my personal testimony that no account which I have seen gives an adequate conception of the incredible size of these vast flocks, which followed one another at short intervals sometimes during an entire day. The apparition seems not to have been so frequent in Virginia as elsewhere, and it was the more terrible in 1675 because it had last occurred before the great Indian massacre of 1644 .

See the strange notions on the propagation of bees in the Insectorum of Movertus, 1634, pp. I2, 1 3. He says that rustic experience confirms the opinion of famous men that bees are bred from the putrefaction of bulls, oxen, cows, and calves. Kings and leaders among the bees are produced from the brain and spinal marrow, common bees from the flesh. My copy of Movertus has on the margin a note in the handwriting of the learned Vossius, who died in 1649 . This is much nearer the truth. Vossius says that the "seed" of the "king" bee, laid in single cells, is like a poppy seed, and from it the little grubs are produced. Movertus, or, as his name is in English, Mouffet, was the first authoritative writer on insects in England. His work was translated in 1658 into English, but I have not had access to an English version. Butler's Feminine Monarchie, published in 1634, the same year with Movertus, shows how much the practical bee-keeper knew

CHAP. I.

Note 9, page 9.

Note ro, page Io. 
Chap. I. that was not suspected by the man of science. Butler holds the principal bee to be a female, but does not know that she was the only fertile female. He knows the drones to be males, and he does not mention the spontaneous generation of bees from bullocks, which had come down from more than two thousand years on the authority of Aristotle and other classic writers. John Baptist Porta, in his Magia Naturalis, 1644, page 53, quotes from Ovid a passage about bodies that in wasting are changed to little animals-in parva animalia verti-and this of the birth of flowergathering bees from the waste of slaughtered beeves:

\section{"deputri viscere passim \\ Florilegae nascuntur apes."}

This passage suggests the absence of any considerable power of scientific observation in centuries preceding the eighteenth. A recent French writer says of the seventeenth: "L'esprit d'observation et à fortiori d'expérimentation, qui nous semble si natural à l'homme d'étude, était à peine né. . . . Quand quelque fait contredisait trop ouvertement la théorie, ils s'en tiraient par une subtilité." Folet, Molière, et la Médecine, 6r.

Note II, page II.

Note 12. page II.

The Gentleman Instructed, I7I3, p. 316: “ He shews us what our idoliz'd Bodies are by the Infection of Lice, Worms, and Toads they produce." Movertus, Insectorum Theatrum, I634, explains the rise of differing parasites on various parts of the human body, p. 260: "Ex humoribus carne adipe, sudoribusque corruptis ortum habent omnes pediculi ; et pro loci humorisque natura longe differunt." The generation of such parasites he regards as an unmistakable sign of misery and sometimes an inevitable scourge of God. This was the notion that Nathaniel Bacon's opponents made the most of in Virginia. On vital products of the putrid humors of the human body, see Levinus Lemnius De Miracvlis Occultis Natvræ, liber iv, page 403 (1604). Lemnius says that snakes are produced from the decay of the spinal marrow.

Art can beget bees, hornets, beetles, wasps,

Out of the carcases ... of creatures;

Yea, scorpions of an herb, being rightly placed.

Ben Jonson's Alchemist, act ii, scene I.

Lord Bacon's Natural History, section 696, discusses the generation of insects. Moths originate, he says, in woolen fabrics, especially those in a moist condition. Bacon had got as far as to suppose that creatures spontaneously generated sometimes 
reproduce their kind by procreation. Compare section 900 . ChaP. I. Dade's Almanac for 1684 says that an unusual number of frogs, fies, locusts, and so on, is a sign of a pestilential season. "For these creatures, being ingendered of Putrefaction, shew a general clisposition of the Year and constitution of the Aire to Putrefaction." In one of the early volumes of the Royal Society's Transactions is a proposition to produce cochineal dye in England by greneration of insects from putrefaction. Sir Kenelm Digby, then much esteemed, says that the earth at the outset was most " aptly tempered and dispos'd" and "brought forth perfect animals; as it now being barrener, of its own accord, produces such as we call insecta, as Mice and Frogs, and sometimes new fashion'd Animals." Peripatetical Institutions, appendix 356, 357. The underlying thought in science and theology was that the world was "worn out" or in decay, and the general effect was a paralyzing pessimism. It was not worth while to do anything notable so near the world's end, as there would be " scarcely any posterity to inherit its memory." See Milton's University oration in Masson, i, 230, and Hakewill's Apologie, generally with others on "great sickness and malice of the times." On spontaneous generation compare Browne's Vulgar Errors, 78, 107, 109, 193, and especially on p. 148 his allusion to "the receipt to make Mice out of Wheat . . . which Helmont hath delivered." Increase Mather in his Illustrious Providences says that demons can make insects, no seminal virtue being required. Compare also Early English Text Society, v, 229, on the generation of eels. But a new spirit of wholesome scientific skepticism was born in the seventeenth century. The first to question the "equivocal generation " of insects, so far as I know, was Aramatori, in a letter written in 1625. Tiraboschi, Letteratura Italiana, xiv, 433. Meantime Dr. William Harvey, one of the first scientific minds of the world, took up the subject of generation and published his researches in $165 \mathrm{I}$. In these his genius struck out the great truth that every animal is from the egg. In regard to insects and their spontaneous generation he speaks ambiguously, but the portion of his work devoted to the generation of insects was destroyed or lost in the civil war, and we can never know just how far he had advanced. See Dr. Ent's letter in Willis's translation of Harrey's works, Sydenham Society, 148 , and the passages in Harvey on Generation, 170, 456. Werner Rolfink, of Jena, the most learned of German anatomists, and a follower of Harvey, published a textbook on chemistry in $166 \mathrm{I}$ in which he rejected palingenesis. 
Chap. I. Sprengel's Geschichte der Arzneikunde, iv, 364. About this time the infant Royal Society of London was listening to papers on " the equivocal generation of insects," on "the making of insects with cheese and sack," and on "the generation of insects out of dead cantharides"; but there was one paper whose title implies true experimentation "of Flesh not breeding Worms when secured from fly-blowings." Sprat's Royal Society, 198, 223. The times were ripening for a great discoverer who should, in spite of Aristotle, extinguish the ancient error and clear the way for modern biology. In I686 Redi, a Franciscan monk, and also an enthusiastic advocate of Harvey's doctrines, published his experiments, showing that " none were generated by putrefaction as the ancients believed." Even so great a naturalist as John Ray was rather slow to receive so surprising a conclusion. Transactions of the Royal Society, Abridgment ii, 765. But though Redi conceded in the spirit of the old philosophy that the "vegetable soul of the plant" might produce the anomalous little creatures found in excrescences, his general conclusion is a broad one: "Venga tutta dalla Semenza reale, e vera della piarte degli animali stessi, i quali col mezzo dal proprio seme loro Spezia conservano." Opere, iii, I 5.

Note 13 , page 12.

Salmon's English Physician, or the Druggist's Shop Opened, 1693: "For a long time it was a received Opinion, that they [the barnacle geese] were bred out of old rotten Wood . . . by the enforming power of water: afterwards that they were bred out of certain Shells, which bred upon or stuck to these pieces of Timber, which by means of Sea-weed are fastened thereto by the holes of the rotten Wood, as Michael Mejer writes." Salmon gives here a long list of authorities, and proceeds: "Gerarde in his History of Plants, I 588, tells us what he had seen with his Eyes and touched with his hands... Shells in shape like those of a Muscle... out of which in time comes the shape and form of a Bird, which when it is perfectly formed the shell opens, and the Bird comes forth, hanging by the Bill; in short space after it comes to maturity and falls into the Sea where it gets Feathers." But the notion had been contested, and Salmon gives some statements in opposition, citing strong words from the closing part of Fabius Columna's Phytobasanos, pp. 507-511. For another convinced eyewitness see Harrison in Holinshed, i, 67, 374, edition of 1807. Compare Bury wills, Camden Society, 243, and Sir R. Murray in Abridgment of Philosophical Transactions, iii, 853, and Dr. T. Robinson, the same, number 172, p. 1036. For a 
modern treatment of the question, Muller's Science of Language, ii, lecture xiii. Lovell's History of Animals, 166r, cites Gesner on this subject, and Douce's Shakespeare, i, 24, refers to Gaspar Schot's Physica Curiosa. The evolution of the barnacle into a goose was not the only absurdity of the sort credited. Lovell's History of Animals and Minerals, I66I, says under "bistard," or bustard: "Some report that they generate by the month by eructation of sperme." On the barnacle compare Dr. Andrew D. White's Warfare of Science and Theology, 36, where the Strasburg edition of Mandeville of 1484 is mentioned as having pictured illustrations both of birds and of beasts produced in the fruit of trees. Bishop Hall proposes for the arms of an upstart boaster of an ancestry traceable to the Conqueror-

The Scottish barnacle (if I might choose)

That of a worme doth waxe a winged goose.

-Liber iv, Satire ii.

In Porta's Magia Naturalis, liber ii, caput iii, is an account of birds produced from the putrefying fruits of trees, and a section entitled Aves é lignorum putrefactione. In this is given, after Gesner, all the details of the spontaneous production of worms in wood that presently have a head, feet, wings, and tail feathers, and grow to the bigness of geese and fly away. Garden sage in decay will also produce birds. One finds in the Manuscript Commission, Eleventh Report, part iii, 27, that Colonel Solomon Richard had observed the barnacle geese to arrive in Ireland on the 2 rst of August for twenty years with their young, and supposed them to have bred in the isles of Scotland. Richard lived in the later seventeenth century.

The first appearance in English dress of what we may call the Scandinavian myth of the swallow is, I believe, in Richard Carew's Survey of Cornwall, I602, folio 25, reverse. "Olaus Magnus," says Carew, "maketh a farre stranger report. For he saith that in the North parts of the world as Summer weareth out they clap mouth to mouth, wing to wing, legge in legge, and so after a sweete singing fall down into certaine great lakes or pooles amongst the canes from whence the next spring they receive a new resurrection. The fishermen in winter doe sometimes light on these swallows congealed in clods of a Slymie substance," etc. Carew also mentions confirmatory accounts received from a Venetian ambassador employed in Poland, and from travelers. In an epitome of Olaus, published in 1562 , the 
CHap. I. swallows are seen in the fishermen's net. Burton's Anatomy of Melancholy, ii, 2, 3, cites both Olaus and Carew, but Burton is staggered by the statement of Peter Martyr that swallows and Spanish kites were flying in Egypt in December and January. An early paper before the Royal Society is entitled "Relation of swallows living after they have been frozen under the water." Sprat, 199. Samuel Johnson, whose chief merit was that he could translate a thing into Latin-English, says " the swallows conglobulate themselves," and so fall down. White, of Selbourne, struggled with the question of the hibernation of swallows; unable to verify the Scandinavian notion of torpor in the mud at the bottom of rivers and pools, he finally accepts in part the older English belief. He says that " many of the swallow kind do not depart from this island, but lay themselves up in holes and caverns, and do, insect-like and bat-like, come forth at mild times, and then retire again in to their latebrae or lurking places." The letter from which this was taken was written in I772. I am indebted to Mrs. Ripley Hitchcock for calling my attention to White's discussion of the question, and for this list of references to Mr. Burrough's edition : i, 35, 49, 8I, 9I, I 49, I 56, I 75 ; ii, I, 41, 83, I 40, I 47, I 58, I 64. $\mathrm{Kalm}$ found the Scandinavian theory prevalent among the descendants of the old Swedish colony on the Delaware. The Dutch at Albany held the other theory of repose in holes in the rocks, while the Canadians and English settlers had somehow come to believe in migration. Kalm's Travels, ii, 146. But the theory of torpidity was held by the Philadelphia naturalist Barton, in the latter part of the eighteenth century. Ord's Life of Wilson, I9I. According to William Bartram, "very celebrated men " were able to believe in it in 1792 , and I have somewhere seen a paper, published in Philadelphia as late as 1800 , combating the very tough delusion that swallows hibernated in the water. In the American Philosophical Transactions, vi, p. 59 (I80I), is a story thirty years old told by Colonel Antes of a swallow taken out of the slime in February. Salmon, whose English Physician, or the Druggist's Shop Opened, is clated 1693, does not mention either of the theories of hibernation so much discussed earlier and later. He treats the swallow, the throstle, and the fieldfare as migratory, on the authority of Aldrovandus and Peter Martyr. Dante held to migration: "Come le augei che vernan iungo il Nilo." Purgatory, xxiv, line 63. It probably holds good of the Latin races that they knew the facts from their residence on the Mediterranean. 
Charles Morton was perhaps the most accomplished scholar that came to New England in the colonial period. He arrived in 1686, and was appointed vice-president of Harvard College, with the expectation of being made president. He read lectures on philosophy at his home in Charlestown which attracted so many from the college that he found it wise to desist. He died in 1698. See an account of him, 2 Massachusetts Historical Collection, i, 158-162, and Quincy's History of Harvard College, i, passim.

Richard, in his Dissertation sur la Possession des corps ... par les démons, Amiens, I746, attributes to the Anabaptists the opinion that the word angel is only the name of an office, and that scriptural angels are subjective apparitions, or rather "les bonne ou les mauvaises pensées." Dufresnoy's Recueil de Dissertations sur les Apparitions, tome ii, part i, page I96. No such opinion, I think, existed among the New England Puritans ; but good angels were not so conspicuous in the theology of the colonies generally as were bad demons. Cotton Mather had great hopes of what good angels might do for him, but that was wholly personal, and born of an imagination that could not be contained within limits. Wendell's Life of Mather.

See the remarks of Sprengel on the increase of demonism after the Reformation, Geschichte der Arzneikunde, iii, 273, 274. Luther inherited the traditions of the humble class from which he sprang, and set the first Protestant example of extreme faith in witchcraft, berating the medical men who traced diseases to natural causes, most of which he himself attributed to the devil. He advised that an afflicted child should be cast into the river Mulde, and complained afterward that he was not obeyed. After the Reformation melancholy and hysterical women could no longer relieve their morbid sense of culpability by a meritorious pilgrimage. Perhaps this sort of faith cure was the greatest benefit of the old religion lost by the Lutheran revolution. Puritanism sometimes drove such brain-sick creatures to stark madness.

The entirely unlawful orleal by water was retained in Protestant England after that which gave it virtue, the prayers of the priest in tying the thumbs and toes together and his solemn adjuration to the water, was suppressed. The wise King James, in his Demonology, felt bound to find another reason for the witch's floating. According to that Solomon, the water rejecied her for having renounced baptism in her bargain with the devil. A full account of the ancient ordeal by water as practiced on the Con-

CHAP. I. Note 15 , page 13.

Note 16, page 18. Note 17 , page 20 .

Note 18 , page 21 . 
Chap. I.

tinent is given by a Dutch writer, Scheltema, in his Geschiedenis der Heksenprocessen, pp. 69 and 70 , and the note in the appendix, 18 and I9, where also the mode of exorcising devils is described. The English witch-finders in the seventeenth century not only lacked the prayers and adjurations of the priests, but the rack having been disused, they were compelled to substitute the torture of enforced vigils and incessant walking to wring confessions from their victims. Both Scheltema and Hutchinson express their belief that the mode of holding the rope had much to do with the witch's floating. See an account of "swimming" a man and a woman at Hartford, Conn., in Mather's Illustrious Providences. Mather strongly disapproves of the custom, which was obsolete in the south of Europe in his time. It was also opposed by all the German academies. Mather cites Sprenger that it had formerly been used for those accused of other crimes. "The devil is in it," he says. The declaration of Chief-Justice Parker, in 17 I2, that if any supposed witch should thereafter die in the dangerous ordeal, those who put her into the water would be held guilty of willful murder, is commonly said to have put an end to the rare sport of baiting old women in England; but, according to Hutchinson, it appears to have been still in vogue some years later. A man was "swam for a wizard " in Suffolk, England, as late as 1825. Hone's Every Day Book, i, 942, quoting London Times of July 19, 1825. It is to the credit of Increase Mather that he insists that witch confessions should be voluntary.

Note 19, page 24.

Note 20 , page 26.

As late as June 14, I7II, Addison printed in The Spectator, No. I I7, his famous essay on witchcraft. "I believe in general," he says, "that there is and has been such a thing as witchcraft, but at the same time can give no credit to any particular instances of it." The politic position taken by Montesquieu in his Esprit des Lois, 1747, livre xii, ch. v, was not very different from Addison's; and Blackstone puts himself under shelter of Addison and Montesquieu; Commentaries, book iv, chapter iv. It was those who believed thus in evil spirits generally, but refused the eviclence in particular cases, that Glanvill calls " nullibists" or no-where-ists.

In Browne's Vulgar Errors, I48, it is set down to be considered "whether the brains of Cats be attended with such destructive malignities as Dioscoricles and others put upon them." See a passage on this subject in Parey's works, book 2I, chapter xxxiv. It is to be remembered that though Paré was not an 
English writer, his works were translated into English and his CHAP. I. name spelled Parey.

I have not thought it necessary to fall into what Milton calls a "paroxysm of citations" on this subject. I have given authorities on specific points in passing, but the witch literature of the seventeenth century is oppressively vast. Some of the Continental writers are referred to in Scheltma's Heksenprocessen, others in Sprengel's Geschichte der Arzneikunde; there is a list of English writers in the Retrospective Review, v, and the late Justin Winsor printed a pamphlet bibliography of American witchcraft. Francis Hutchinson's work is the best on witchcraft generally. No subject within the scope of history can be more dreary to the student of original authorities, more revolting to humane feelings, or more disgusting in many of its details. Upham's Salem Witchcraft, with an account of Salem village, is the only work on the witches in Salem on which one can depend. It has no chapters and no index worthy of the name, and is utterly exasperating, but it is a full account of the witchcraft ordered and made clear. Upham did not know how to make a book, he did not know the subtle laws of mind, but the external facts are well given. I have had recourse to nearly all the other data as well, from Cotton Mather and Calef down. 
CHAPTER THE SECOND.

DIGRESSION CONCERNING MEDICAL NOTIONS AT THE PERTOD OF SETTLEMENT.

I.

CHAP. II. The circulation of the blood. Harvey's Prelectiones Anatomiæ Universalis, 72-8o, and Exercitatio de Motu Cordis, Frankfort, 1628 .

Aubrey quoted in Prefatory Memoir to the reprint of Exercitatio. Comp. the Life by Willis in Harvey's works.

Quoted by Folet in Molière et
To the historian of medicine the early seventeenth century seems a period of brilliant discovery, for, in 1616 , while Virginia was yet in its birth throes, William Harvey first expounded to his students the circulation of the blood, which he published to the world twelve years later. But to the student of culture history the stubborn resistance offered to this capital discovery is one of the many signs of the thralldom of the age to tradition. So unusual was the spectacle of a man questioning the conclusions of the ancients that Harvey was accounted "crack-brained," his practice declined, and a pack of "barking dogs," as he calls them, were soon baying at him. "Would you have us believe that you know something that Aristotle did not know?" demanded one adversary, Dr. Primrose. "Aristotle observed everything," he adds, "and no one should dare to come after him." The voice of Primrose is the voice of that age. It is said that no man over forty years old accepted Harvey's new physiology. Half a century after Harvey's discovery the medical faculty of Paris, 
noted for its spotless orthodoxy, solemnly petitioned the French king to prohibit the teaching of the circulation, as a doctrine contrary to the authority of Aristotle. Against the plated hulk of this conservatism Boileau let fly a broadside of derision in the shape of a burlesque decree, in which among other things the court "forbids the blood to be any longer vagabond, wandering and circulating about the body, on pain of being wholly given over to the faculty of Paris to be let without measure." Harvey "gave to anatomy its most illustrious discovery, . . . and to philosophy its first real alliance with experience," says a German writer, and we like to linger over the story of the most shining intellectual achievement of the century. But its relation to anatomical knowledge in America in the seventeenth century is small. It is probable that few of the earlier doctors and chirurgeons who came to the colonies were interested in the question raised by Harvey. I It is certainly improbable that anything new in science ever came into possession of the barbers and bloodletters and bonesetters who practiced the rougher sort of surgery and physic in England and the pioneer settlements of America, nor would novelties of any sort influence the practice of traditional medicine by the preacher of the parish or some jack-at-all-trades who served as justice of the peace, medical adviser, and neighborhood wiseacre. Still less would there be any advance in that "kitchen physic," as the colonists were accustomed to call it, that was so

Chap. 11 .

la Médecine, 8r.

Comp.

Revue Scientifique,

Nov., I893, on La Circulation et ses Detracteurs.

Euvres de Boileau, ed. 1821 , iii, 120. Earlier form of the Arrêt Burlesque.

Isensee, Geschichte der Medecin, I. Theil, 255 . 
Снар. II. liberally dispensed by midwives and knowing house mothers who revered neither Galen nor Hippocrates, but followed mediæval traditions and employed remedies that may have been older than the father of medicine himself. In I66o the circu-

Subjects for Master's Degrees at Harvard, I.

Humorism.

Note I.

Note 2.

Aphorisms of Hippocrates.

Paulus Agineta, b. vii, sec. 2. Comp. especially extracts from Aëtius in Adams's Commentary on P. Egineta, lation of the blood was argued in a master's thesis at Harvard, which institution seems to have been about that time hospitable to new opinions in science. This was thirty-two years after Harvey's treatise had appeared. The circulation of the blood was still a question at Harvard in 1699.

II.

That which one age tells to another seems to men truth fundamental. From antiquity it had been told and retold with much formality that the human body consisted of four elements-earth, air, fire, and water-and that it contained just four humors or liquids corresponding neatly in number with the four elements. These humors were bile or choler, blood, melancholy or black bile, and phlegm. In the mystical science of that time a mysterious relation or correspondence was supposed to exist between each of the several elements and one of the four humors. Anne Bradstreet, the beginner of New England poetry, sets it forth in rhyme, that choler was the daughter of fire, blood of air, melancholy of earth, and phlegm of water. Disease came from an excess of one or another humor, or from a humor's being too cold 
or too hot, or too moist or too dry. The four humors, offspring of the four elements, had these four qualities, cold, heat, moisture, and dryness, which were something other than what we mean by these terms. Each of these qualities might exist in either one of four degrees of intensity, not only in the humors but in the food and remedies. A writer in 1603 estimates the possible mixtures and wrong-goings of the four humors at eighty thousand. This afforded a system of diagnosis fairly bewildering and impressive to the patient. The belief that the humors wrongly mixed or tempered affected the mood of a sufferer was a commonplace of the literature of the period. "Humor . . . some time hath his hour with every man," says Shakespeare's Portia to Brutus. Certain forms of speech that gave expression to humoral theories still persist as petrifactions of extinct notions. The words humor, temperament, bilious, choleric, atrabilious, melancholy, phlegmatic, and others, are veritable fossils of the Galenic age. The numerous simples, such as sassafras and sarsaparilla, that are yet decocted to remove morbid humors and "purify the blood," are but remains of Galenism, and nostrums that restore health by invigorating the liver show the survival in folk-science of the old physiology that gave supremacy to that organ, or of the theory of ancient medicine that "the liver is made up from the roots of the veins" and that it was the center of life, the desires of the soul being there seated.

Chap. II. Sydenham Soc., iii, 6 , and old medical literature generally.

Note 3.

Sprengel's Geschichte der Arzneikunde, v. 25 , citing Sanctorius.

Julius

Cæsar, ii, I.

Note 4. For example, Aretæus of Cappadocia on Acute Diseases, ii, vii, Sydenham Soc. edition. 
Chap. II.

Common remedies.

Note 5.

Compare

Molière's

Malade

Imagi-

naire,

third

interlude.

Adams's

Paulus

AEgineta, iii, 483 and ff. Comp. Maurice

Raynaud, Les Médecins au

Temps de Molière, $\mathrm{p}$. I8I, and

Folet, 87 .

Hippocrates, Aphorisms, vi, 47. Paulus Ægineta, b. vi, sec. 40, with Adams's Commentary, ii, 320.

Comp. Rhazes on Smallpox, 37.

Raynaud, Les Médecins au Temps de Molière, I 80 .
III.

The physicians of the seventeenth century wereacquainted with the properties of many valuable simples. They had a set of astringents and cathartics handed down from antiquity. Some of the latter are so drastic that nothing could have justified their use but the necessity for evacuating humors which had a depraved way of going wrong and sending up poisonous vapors to the brain, to the injury of those imaginary "animal spirits" which played a leading part in the physiology of the age. The several purgative remedies were supposed to act specifically, each on one or more particular humor; one thing was needed for phlegm and quite another to remove the black bile that weighed on the spirits of a hypochondriac. The favorite and perhaps the most destructive remedy of that time was venesection. Hippocrates had used it with caution, thinking it best in the spring time. Galen forbade bloodletting in the case of persons under fourteen or over seventy years old. But in the seventeenth century it was inflicted on men, women, and children for almost every pathological offense. Louis XIII was bled forty-seven times in twelve months. Infants of three days and men past eighty were thus depleted: the "peccant" humors had to be expelled. Venesection was supposed to be local in its effects and a vein was opened in the head for troubles in the head. The French when depleting 
generally opened a vein on each side of the body, supposing in their ignorance of the circulation that otherwise it would require twenty-four hours to restore by some process an equilibrium. The great surgeon Paré drew seven pounds of blood, troy weight, from a man in four days; and there was a case in England of almost as severe a treatment inflicted on a man seventy-six years of age. Bleeding was used by barbers and other humble practitioners. In the American colonies it was practiced by the half-taught chirurgeon, as well as by clergymen and other medical amateurs and dabblers, to whom the old almanacs pointed out the proper time of the moon for letting blood according to the age of the patient.

Chap. 11.

Comp.

C. Sprengell on the Sentences of Celsus, passim. Howell's Letters, i, 2, Letter xxi.

Note 6. Parey (Paré), works, lib. Io, c. xiv, and Deodati's Letter in Appx. to Hakewill. Compare Medicine in Mass., 43.

IV.

The great medical controversies which the early seventeenth century had received by way of legacy from past ages wakened few echoes in America. The Latin countries generally held to Greek and Arabian traditions, while the Germans were following the insurgent Paracelsus and the chemical school-doctors of fire, or pyrotechnics, as they called themselves. But the seventeenth century was a period of approach and attempted reconciliaMedical sects. tion. Pott, the English physician who was sent to Virginia in its early years, was thought all the better qualified because he had studied in the Low Countries, and was acquainted with chemistry. $\mathrm{He}$

Sprengel, Geschichte der Arzneikunde, iv, 34I, note. Browne's Vulgar Errors, 72. 
Chap. II.

Hakewill's Apol., iii, v, pp. 244, 245.

J. Clayton to Royal Society.

See Force's reprint.

William and Mary Qrly., ii, I 7o. MS. county records in $\mathrm{Va}$. State Library generally.

J. W.

Deane's

Sketch of Wigglesworth. Inventories of books generally. appears to have combined Galenical with the chemical methods, and there were other eclectics at the time. Some stiff Galenists in England were suspected of using spagyric methods surreptitiously. If any allusion to medical sects was made in the newly planted colonies, no record of it has come down to us ; the people, in their necessities, availed themselves eagerly of any science or promising quackery or ignorant folk-physic that offered relief, reserving all their polemics for theology. One finds remedies dating back to Galen and Hippocrates standing on the family medicine shelf of nearly every plantation house of Virginia; the Oriental bezoar stone of somebody in the middle ages and the ancient dittany of the Greeks were prescribed by colonial doctors. But in the little medical libraries Glauber's Chemistry holds up its head alongside of Galen's Art of Physic, and even the Unlearned Chemist ventures to keep company with Ambrose Paré's Surgery. In New England, as in Virginia, Barrough's Method of Phisicke was the accepted handbook for nearly a hundred years. Wigglesworth had Barrough with Harvey and Culpepper; but it is significant that several Paracelsian books, such as the Basilica Chymica, were their friendly shelf neighbors. One is forced to conclude from the collections of books that colonial medicine at least was rather inclusive. Governor Winthrop, of Connecticut, whose influence must have modified medical practice in New England, appears to have belonged to the chemical 
school, and to have held strongly to hermetic CHAP. II. medicine of various kinds.

V.

The doctrine of signatures, so often ascribed to Paracelsus and strongly upheld by him, pervaded medical theory in the colonies. The notion was, Signaturism. indeed, as old as Hippocrates himself, and probably yet more ancient, since it is found in the primitive medical theory of savages. But writers of the Paracelsian school of the sixteenth century amplified, emphasized, intricated, and mysticized the doctrine in such a way as to make it seem almost an original discovery of their own time. Theories were accepted in that day for poetic rather than scientific reasons. Whatever thought was reached by symbolism, or uttered obscurely or mystically, impressed the susceptible imagination of the age. The imagination then held the place of authority that rightly belongs to the judgment. The later and elaborate doctrine of signatures was a part of the prevalent philosophy of correspondences. It was related to the influence of the planets on plants and minerals, which influence was shown by color and other qualities and had to do with medical properties. It was a part also of an obscure theory of sympathy and antipathy existing in inanimate things-a doctrine suggested apparently by the magnet. It belonged to the overshadowing supernaturalism of the time, 
Chap. II.

De Cutis Apertionibus, folio * 62.

Dr. Stafford's paper.

and to the geocentric and homocentric notions of the universe that gave value to things only in their relation to man. The world was a cosmic pharmacy; God had placed a signature on each substance to indicate the disease it was good for. What was necessary was to read the label, to note the indications of odor, color, form, and other marks. The resemblance was often wholly external. "Like by like is to be cured-that is, similar ulcers by similar forms," says Paracelsus. The porosity of the leaves of St. John's-wort, and the spots which resembled perforations of the leaf, left no doubt of the value of the plant in all cases of abrasion, external or internal. The illusory appearance of holes in its leaves showed it good for hallucinations, madness, and assaults of the devil. This curious theory of medicine is to be detected in many of the remedies prescribed in the colonies, and is yet more evident in the popular modes of healing.

VI.

We may see the influence of the theory of signatures on English medicine in actual transit to the colonies by examining a paper sent by Dr. Stafford, of London, to Winthrop, Governor of Connecticut, the most noted master of medicine in the early colonial period. In this paper are remedies which must have been often prescribed in New England. Stafford cured "madnesse" with St. John's-wort "sometimes in five days." Paracelsus had treated 
the fibers of its leaves as a signature, showing that this plant was good to drive away "phantasms and specters." But the doctrine of "curing by the assimulate" was perhaps present even in superstitions before the time of Paracelsus; the water of St. John's-wort was used to drive away devils, and the herbs St. John's-wort and rue were blessed after a prescribed form, wrapped in a "hallowed paper," and carried about "to be smelled at" agrainst all "invasions of the devil." The inhabitants of North Wales put sprigs of it over their doors as an antidote to demons. 'Stafford gave sweet milk with salt for "jaunders." Milk, being white, cleared black humors. This was "contraries cured by contraries," but Stafford used both methods in one remedy; he added saffron to his milk and salt for jaundice, and this was "curing by the assimulate," a yellow remedy for a yellow disease. If a patient were torn by pains in the breast or limbs, Stafford cured like by like; he bade him wear a "wild catt's skin on the place grieved." But our London doctor's masterpiece, as communicated to Connecticut, appears to have been his "black powder" against smallpox and other eruptive diseases. It was made of toads because toads were believed to be poisonous, and all poison drew poison to itself, and thus cured disease, as the author of the Triumphal Chariot of Antimony had long before proved. This also was one mode of curing by the assimulate. But the warts on the toad were perhaps regarded as a specific divine indorsement

Chap. II.

Paracelsus, Opera, fol. IgI ff. The Book of Quinte Essence, E. E. Text Soc., p. r9.

Hall's Cases of Consc., Dec. 3, Case I, citing Thesaurum Exorcismorum. Barton's Med. and Phys. Journal, May, i, pt. ii, 60.

Note 9.

Compare Adams's Paulus Agineta, ii, 207. Basilius Valentinus. 
Chap. II. Of his value against eruptions. "In the month of March," says Stafford, with the usual particularity of time, "take toads as many as you will alive; putt them in an earthen pott, so that it may be half full; cover it with a broad tyle or Iron plate; then overwhelme the pott so that the bottome may be uppermost; putt charcoales round about it and over it. ... Sett it on fire and lett it burne out and extinguish of itselfe; when it is cold take out the toades; and in an Iron mortar pound them very Note ro. well." By a second roasting this brown toad powder was reduced to a black, innocuous animal charcoal. "Moderate the dose according to the strength of the partie," says Stafford gravely. A toad boiled in oil, "after the toad has fasted two or three days,"

O. W.

Holmes, Mass. Hist. Soc. Proc., x862, pp. 379-382.

Weapon ointment and sympathetic powder.
VII.

Beside the doctrine of signatures and a superstitious etiquette in the preparation of remedies, there were other curious results of the mystical tendency in the medicine of the time-the weapon ointment derived from the Rosicrucians, for example. It was compounded of many absurdities; there was pulverized bloodstone, a cure by likes, 
and there was also moss taken from the skull of a dead man unburied and other ghastly ingredients. Chap. II. Note 1 r. This precious unguent was applied, not to the wound, but to the weapon or implement that had produced it. The weapon was then carefully bandaged, to protect it from the air. It was the wound, however, that was healed; the cures are well attested, as impossible cures usually are. Experiment proved that "a more homely and familiar ointment" would serve the turn just as well, and moreover, in that day of emblemism, the ointment proved quite as efficacious when applied to an image of the offending weapon. To the Rosicrucians was attributed also a similar cure which came into great notoriety in England in the middle of the seventeenth century. This was the widely Sprengel, Geschichte der Arzneikunde, iv, 345 . famous sympathetic powder made of vitriol with much ceremonial precision. The powder stopped hæmorrhages either from disease or wounds. It was applied to the blood after it had issued from the wound or to the blood-stained garment. Winthrop, of Connecticut, imported the latest books on the subject of this powder, which may well have come into use in a new country where surgical cases were not infrequent. Before Winthrop's time, and after, German writers on medicine attempted to give a scientific basis to the weapon ointment and powder of sympathy by attributing their operation to magnetism, a term that has covered more ignorance than any other ever invented. The philosopher Kenelm Digby, a con- Note 12.

E. g., De Pulvere Sympathetica, I650.

Sprengel, as above, iv, 345,346 . 
CHap. II. temporary of Winthrop, made himself the protagonist of the powder in a treatise on the subject. Lord Bacon was in some doubt about the weapon ointment, but he rather inclined to believe in its cures, because a distinguished lady had similarly \begin{tabular}{l|l} 
Bacon's & relieved him of warts by rubbing them with a rind \\
Nat. Hist., &
\end{tabular} 997. of pork, which was then hung up, fat side to the sun, to waste vicariously away, carrying his warts into non-existence with it. Roberti, the Jesuit, believed that such cures took place, but ascribed them to the devil; all these cures that were wrought without "contaction," including the home-

Hall's

Cases of

Con-

science, 232 , note.

Note I3.

Potable gold.

Burton's Anat. of Melancholy, sec. I, 3 .

Note 14.

\section{VIII.}

The seventeenth century lay in the penumbra of the middle ages, and the long-sought potable gold of the alchemists was yet in request; it even enjoyed a revival. Almost everything precious and rare was accounted of medicinal virtue, and it was inferred that gold as the most precious metal would be the most valuable remedy if it could be taken in liquid form. The known usefulness of mercurial remedies was attributed to the fact that mercury was the densest of liquids. Gold was the densest metal then known, and it 
was easily decided, by the process of using fancy to grive fluidity to logic, that if it could be reduced to drinkable consistency it would be the most valuable of medicaments. There was a yet more convincing way of proving its medicinal value by the process of presumption, so much used by hermetic philosophers. The sun and gold were related in the mystical thought of the time; the sun as chief luminary was "lord in the property" of gold. "There is not found among things above or things beneath," says Glauber, "a greater harmony and friendship than that between the sun, gold, man, and wine." The easy logic of the time found in this transcendental fancy a "therefore" potent enough to make gold a universal remedy for human maladies, where the recovery was not "contrary to the unfathomable counsel of God." Gold Note 15. Glauber, De Auro Potabile, 3, and Georgius Phaedro, Vom Stein der Weisen, 1624, 394397. Note r6.

Note 7 . was even administered in its solid state; Arabic doctors had prescribed leaf gold, and it held place in several compounds. Fragments and leaves of gold were seethed with meats, and the broth used to clear the heart and raise the strength and vital spirits of invalids beyond all conception. But the Lemnius, De Miraculis Occult. Nat., r604, pp. 309, 3 Io.

hermetic writers thought the use of leaf gold a coarse application of a metal which they were fond of styling "the lower Sun." Preparations professing to be potable gold and tincture of gold were in much request and frequently administered in the seventeenth century. On the other hand, their efficacy was warmly debated. The alchemists held that three drops at the highest taken in wine or $\begin{aligned} & \text { Von Ro- } \\ & \text { dach. }\end{aligned}$ 
CHAP. II. beer would cure the most serious illness. Of its nature it is more than enough for us to know that it was triplex, being vegetable, animal, and min-

Geber, quoted in De Via Universali.

eral; it was one thing chosen out of all others, of a livid color, metallic, limpid and fluid, hot and moist, watery and swarthy, a living oil and a living tincture, a mineral stone and a water of life of wonderful efficacy. So spake the admiring alchemist.

John Winthrop the younger, of whom we have spoken, was a man of an eager and curious mind, fond of peering into the occult. He dabbled in alchemy as well as astrology, and on his shelves were many of the latest works on potable gold. A poet of his time says of him:

Were there a Balsam, which all wounds could cure, 'Twas in this Asculapian hand be sure.

Green's Medicine in Massachusetts, quoting Cotton Mather.

Note 18.
He left a son Wait who inherited his father's fondness for prescribing, and who like his father was an adept in panaceas, and was believed to have golden secrets and secrets more precious than gold, "unknown to Hippocrates and Helmont." Doubtless many New-Englanders were dosed by the revered Winthrops with the tincture of the sun, potable gold, made by marrying in some fashion the "masculine gold" to the "feminine mercury," and possessing all virtues-vegetable, mineral, and animal-"destroying the Root and Seminaries of all malignant and poisonous diseases." 
IX.

Weapon ointment, sympathetic powder, potable Theriac and remegold, were much thought of, but the authorized dies of serpharmacopœias ignored these Gothic medicines pent's that traced their origin to alchemists and Rosicruflesh. cians. Yet the notion of a universal antidote was in regular medicine as well. Primitive science, having no reins on the imagination, longs for perfection, seeks the universal, and dreams of great discoveries. Back through a long line of medical writers we may trace the belief in the virtues of theriac and mithridate to Galen and into the centuries before Galen. The accepted story of its origin is that Mithridates, King of Pontus, by a series of experiments on criminals, had found out, or thought he had found out, what medicaments would neutralize various poisons. These he put together for a universal antidote. Andromachus, physician to Nero, changed the constitution of the remedy somewhat, adding the flesh of the viper, probably on the principle of curing like by like. This remedy of Andromachus was the famous theriac which was so much lauded by Galen and which imposed itself even on modern times. It was expelled from the British Pharmacopœia only in the middle of the eighteenth century by a bare majority of one vote in the college. It contained more than sixty ingredients, and was commonly known in England as Venice treacle. Not only all poisons but many diseases were supposed to be

Galen, De Theriaca ad Pisonem, and De Antidotis Epitomes. Adams, Paulus Egineta, iii, 528 . 
Chap. II. Maranta, De Theriaca et Mithridatio, 1576 .

Note 19.

Comp. Adams on P. Agineta, iii, I2I. Judd's Hadley, 36r. Josselyn's

Two Voyages, II4.

Byrd's Westover Papers, 66. Juvenis, De Medicamentis, 240, and Salmon's Eng. Physician, 763

conquerable by this universal remedy. Numerous other preparations of viper's flesh were in use; things poisonous were thought to contain much virtue. What theriac was used in the colonies was no doubt made abroad. In less complicated preparations the American rattlesnake was made to take the place held for thousands of years by its rival in virulence, the European viper. The flesh of the rattlesnake was fed to the infirm, perhaps in broths as the viper was given for ages, and as the Scotch used the adder. His gall mixed with chalk was made into "snake balls" and given internally; his heart was dried and powdered and drunk in wine or beer to cure the venom of the snake, on the ancient principle of curing by likes. In Virginia the oil of the snake was recommended for gout, while in frosty New England the fat was, if we may believe Josselyn, "very sovraign for frozen limbs... and sprains." The American backwoodsman of to-day, perhaps unconsciously, uses a homely substitute for the viper wine or theriacal wine of other times when he soaks the flesh of the rattlesnake in spirits to make "bitters" against rheumatism.

X.

Bezoar.

There was yet another universal antidote recognized in the regular medicine of the time. The bezoar or bezar stone was a concretion taken from the intestines of wild goats and other animals. That brought from the Orient was accounted most 
valuable. It was used at first in the East as an Chap. II. amulet; there were other remedies of olden times that served their purpose just as well when worn about the person as when taken medicinally. A "stone" found in so unusual a place excited wonder, and there grew up a mythical notion of its origin. This particular wild goat, in the opinion of the sixteenth century, indulged itself on occasion in a diet of poisonous snakes. To cool the burning produced in its stomach by this debauch, the creature plunged into the water. On coming out it sought and ate of health-giving herbs, and as a result the bezoar was concreted in its vitals. The cost of the bezoar, the "queen of poisons," was great. "If you take too much, your purse will soon complain," says a medical writer in I66I. The concretions of the "mountain goat" were the original bezoar, but any intestinal formation of the kind came to be considered bezoar. In Java the viscera of the porcupine were Monardes, Eng. ed., page 3 , and Acosta, livre 4 , chap. xiii.

Tanner's Art of Physic, 515. eagerly searched for such deposits, and one of these worthless things called a pedro porco was sold for the price of pearls. There were ruminants in Chili and Peru that yielded bezoars, which ranked second to those of the East; Mexico Castrillo, chap. xxvi. contributed a lower grade still. Finding these Note 20. stones valuable, the shrewd Indians learned to counterfeit them, and as they were of all sizes, colors, and forms, and there was no test of fineness, there were others than natives who knew how to sophisticate, so that the famous powder magisterial 
Снар. II. of bezoar often probably contained nothing of the kind. The remedy was used in the colonies. Clayton, the parson who was in Virginia before I690, tells of a skillful woman physician there who gave pulverized "oriental bezoar stone" in the case of a man bitten by a rattlesnake and followed it with a decoction of dittany, the same at least in name with that ancient remedy which Venus apÆneid, xii, plied to the wound of her son Aneas, and to which 412.

the wild goats in those knowing times resorted when the winged arrows of the hunters were sticking in their sides. We get a notion of the persistNote 2x. ence of medical tradition when we find administered in Virginia an antidote brought into Eu-

Comp. Hatfield rope from the East in the middle ages and an orthodox simple derived from the remotest Greek antiquity, and both of them probably without merit.

\section{XI.}

American herbs.

This magic of dittany has much instruction for us who study the genesis of colonial medicine. Not only Cretan dittany, but white dittany as well, was esteemed efficacious against the poison of "serpents, mad dogs, and venomous beasts." Medical theory was very expansive. Because the plant that grew on the Cretan mountain sides was fabled to expel the barbed arrows that remained in the wounds of the wild goats, Cretan dittany and white dittany were accounted potent not only to cure poison, but to extract bits of wood or bone 
from wounds, and to remove foreign bodies of all Chap. II. sorts, and even to assist in parturition. Dittany was such an antagonist to poison that Gerarde is quoted as saying, "The very smell driveth away venomous beasts, and doth astonish them." Whether the Virginia doctors mentioned in the preceding section cured the rattlesnake's bite by using Cretan or white dittany, or perhaps by neither, is not certain, for by a curious process the name and virtues of dittany had before this time been transferred to American pennyroyal, which appears to have been still more astonishing to a snake than dittany. Captain Silas Taylor told the learned Royal Society, ever eager in that day to hear of marvelous discoveries from returning travelers, that in 1657 he had held to the nose of an unwilling rattlesnake the bruised leaves of "wild pennyroyal, or dittany, of Virginia." The serpent was killed by the antidote in half an hour. Other virtues of dittany were ascribed to pennyroyal in New York; here it was also used against rattlesnakes. But the name dittany, or American dittany, was presently settled by early Virginia botanists on Cunila Americana, and the miraculous virtues ascribed to Cretan dittany anciently, and later to European species and to pennyroyal, were finally

Royal Soc. Phil. Trans., Abridgment, ii, $8 \mathrm{II}$.

Gowan's Wooley, 43,44 . Meehan's Monthly, Nov., 1897, on American dittany. Glover in Phil. Trans., Abridgment, iii, 572. attached to the so-called American dittany.

It was by such processes that many American herbs became medicinal. A fancied resemblance caused the name of a European plant to be transferred, sometimes to more than one American spe- 
CHap. II. cies, and with the name was carried over the traNote 22.

Glover to Royal Society, Abridgment, iii, 570 .

Two Voyages to New England, $6 \mathbf{I}$. ditional virtues. Favorite herbs were transplanted from English gardens to those of colonial house mothers, who even took pains to cultivate in America the wild plants they had been wont to pluck for simples from English hedgerows. But the seeds of English weeds emigrated by smuggling themselves with better company, and the hardy vagabonds of English roadsides gained an easy advantage over the feebler natives of the American banks. Herbs from Europe soon put on the airs of native Americans. There was no lack, therefore, of old acquaintances for simples, and the wild woods were full of new plants and animals presumed to be of pharmaceutical value, for the idealism of the time denied that anything was superfluous. "We have the Scriptures to back it," says Josselyn, "that God created nothing in vain."

\section{XII.}

Botanical researches Comp.

Tiraboschi, Storia della Letteratura Italiana, xiv, 424,431 .

Note 23.

Compare

Latham's

Life of

Sydenham, in

The search for new remedies in the bewildering jumble of hitherto unknown plants revealed by the discovery of America gave a new interest to botany, which was the foremost of the biological sciences in the seventeenth and eighteenth centuries. Jesuit missionaries in South America learned from the natives the medicinal value of the bark of the cinchona tree, in $16_{32}$, and it was at length introduced into European medicine. This was the greatest trophy of botanical research in 
the New World, though the Old World met the discovery with stubborn prejudice and resistance. The brilliant results achieved in malarial diseases by the use of Jesuits' or Peruvian bark after its general introduction into Europe, about the middle of the century, probably awakened expectation of similar discoveries in North America. The traveler Josselyn, who arrived in New England in 1663, was an assiduous herb gatherer; he examined the weeds and woods and wild beasts to find novel remedies, and he has recorded for us the popular applications of many new substances. Glover, and Clayton the parson, and the botanist Bannister, were observing Virginia plants in the latter part of the seventeenth century. In the eighteenth there were several eminent native botanists, and others came from Europe. To three of these-Kalm, a Swede; Schöpf, a German; and Castiglione, an Italian-we owe the most careful observations, not only of the plants bet of social conditions in America.

XIII.

But the popular use of American plants and animals did not depend on botanical research. The general belief was that all things were made with reference to man. The wild woods were full of creatures whose value was written on each of them in the language of signatures, if the seeker for simples could only manage to decipher the

Chap. II. p. $\operatorname{lxxv} \mathrm{ff}$. Comp. CEuvres de Bayle, i, 267,268 .

Note 24 . Signaturis $m$ in America. 
Chap. II.

Two Voyages, 64 , 65,72 .

Two Voyages, 99.

Labadists' Journal, 83.

Glover in Phil. Trans., Abr., iii, 567.

Brickell's Carolina. label with which it had been considerately tagged at the creation. If we look into Josselyn's list of American remedies, we shall see how much painful observation and investigation had been saved by this shopkeeper scheme of Nature. The bark of the board-pine was naturally good for the skin; rosin gathered on the bark was used for outward application; turpentine procured by incisions was "excellent to heal wounds and cuts." Even cosmetic applications were probably suggested in the same way; green pine cones having a corrugated surface were good to remove wrinkles from the face; water distilled from them was "laid on with cloths." The familiar kidney bean, first known to Europeans in the gardens of the American savages, was "good to strengthen the kidneys," as anybody might know at sight. The signature might be "internal" as well as external, and very opposite deductions were sometimes made. The French thought that the mottled eggs of the American turkey bred leprosy, but the English colonists thought that the similar eggs of the turkey buzzard were able to "restore decayed nature exceedingly." From some association of symbolism the brains of the shark and jelly from the head of the drumfish were thought to assist in obstetric cases. Brickell, a medical man, records the fact that the pit of the Carolina haw was thought serviceable in cases of "the stone, gravel, and dropsy," and he recommends the brains of the screech owl for headache. As in Europe signatur- 
ism would seem to have had its first lodgment in the superstitious use of amulets, so in America like cured like when merely worn about the person. In New England the fangs of wolves were strung about the necks of children to save them from fright; and the cast-off skin of the rattlesnake was worn as a girdle to facilitate parturition. The practice must have been pretty general, since we find it in Connecticut and Pennsylvania. No doubt the custom which still obtains in malarial regions of wearing a necklace of caterpillars to cure ague by shuddering, antedates the discovery of Peruvian bark. In the seventeenth century a spider inclosed in a nutshell, wrapped in silk and hung about the neck so as to touch the skin, " did much to drive away intermittent fevers more quickly." In England the patient was sometimes dosed with the spider, and the practice is still known in English folk-medicine. In the valley of the Ohio, spider-web pills are given by rustics to cure ague. The use of spiders in some form against intermittents is more than two thousand years old; Greek physicians, before the beginning of the Christian era, put a plaster of them on the patient's forehead.

It is to be remembered that in the ages before science it was held that in case of recovery there must have been a remedy. Nothing got well of itself. Now we know that the great majority of ills will heal themselves. In every case of spontaneous healing in that time a remedy was looked

Chap. 11. Compare Monardes on bloodstone, ed. I 577 , folio I\&, reverse. Note 25.

König, Regnum Animale, I64. Gentleman's Mag. Library of Pop. Superstitions, 128.

Comp.

Longfellow's Evangeline, i, 3 . Lovell's Animals and Minerals, I66r. Adams's Paulus AEg., iii, 49. Compare also König, as above, , $164,165$. 

Снар. II. for, and so nearly everything was believed to be a remedy for something.

\section{XIV.}

Animal remedies.

Note 26.

Brickell's Carolina, passim. Green's Medicine in Mass., 22, and many others.

Note 27 .

Many remedies were in use in the early colonial practice and in Europe that seem to have had nothing to recommend them except an unconfessed notion that disgust was curative, and the belief that nothing was made in vain. Pulverized butterflies, crickets, and grasshoppers are not the worst of these by several degrees. Sowbugs were highly esteemed; earwigs and emmets, which sometimes crept into the ears, were good for deafness and were given in oil; tumblebugs for some reason cured rabies, and bedbugs were valuable in lyingin cases, perhaps from their clinical associations. Even more intimate vermin were given alone or put into compounds. The skins, the viscera, and the dejecta of animals were in use, and many of the most loathsome of these substances were found in the regular pharmacopoias. Human orts and ends were highly prized; the volatile salt of men's bones was especially "homogeneal to humane nature"; the scrapings of human skulls, human fat, and the liquid called mummy distilled from dead bodies were devoutly believed to have much effcacy. It was only as time wore on that organic chemistry arose to deliver the afflicted from the nauseous and the noxious by dumping whole pharmacopœias of vile medicament into the homogeneal sewers. 
XV.

I The colonists fell into a common error of unscientific men: they overestimated the value of the medical hocus-pocus of the savages. In Pennsylvania they were, in 1696 , pronounced "as able physicians as any in Europe." Indian physic was in great part empty jugglery against imaginary spirits, but in rough-and-ready surgery the savages had some arts useful in the exigencies of forest life. They had herbs for cathartics and emetics; they taught the colonists the use of various roots which they believed to be antidotes for the bite of the rattlesnake. Byrd is able to name nearly a dozen of these supposed antidotes. One of these, the so-called Seneca snakeroot, came into great reputation in Europe as a general medicine. John Clayton the clergyman collected three hundred species of plants used as remedies by the Indians. Quacks in the colonies soon learned the trick of claiming to have medical secrets from the medicine men of the Indians. As early as the beginning of the eighteenth century this cloak for ignorance and imposture was found convenient, and the "Indian" or "botanical" doctor was already plying his trade.

XVI.

It was the usual practice to send out with each "plantation" or settlement a surgeon who knew

Colonial medical some physic. One of these was allowed in I6I9

Watson's Annals, i, 69 .

Note 28 .

Westover Manuscripts, 42.

\section{Royal}

Phil.

Trans., xli, 143 and ff., 1687 . Lambert's Hist. of New Haven and Milford, II2. men. 
Chap. II.

Smith of Nibley MSS.
Comp., for example, Accomac Records, 1633-'39, passim, and York Records, 1638, 1639, and 1645 .

Note 29 .

MSS. Records, Accomac County. thirty shillings a month. As money then went, thirty shillings would be equal to nearly as many dollars now. Dr. Pott, a Master of Arts, and both chemist and Galenist in training, a somewhat reckless liver, a councilor, and for a short time a temporary governor, was the only physician in Virginia in 1630 . Involved in the factional intrigues of the time, only his medical skill saved him from being hanged out of hand for theft by the arbitrary Sir John Harvey. Harvey could not muster courage to put to death the only competent medical man in the whole colony in a time of epidemic. A like indispensableness probably saved Pratt, a surgeon of Cambridge, Mass., from banishment for free speaking. There were in Virginia a good many rough practitioners of one sort or another; in the manuscript county record books of this early period they are called "chirurgeons." The barber, who practiced minor surgery along with shaving and hairdressing, was a natural outgrowth of the conditions existing in the middle ages. But conditions had changed, and the barber surgeon was in a fair way of extinction from unsuitableness to environment when the colonies were settled. In ${ }_{1} 6_{3} 8$ a barber surgeon lost his life journeying from Boston to Roxbury in a snowstorm to pull a tooth. In a Virginia inventory of 1640 sixteen kinds of drugs are mixed up with a hone, a razor, a lancet, and four other implements of a surgical barber. In 1652 the surgeons of $\mathrm{New}$ Amsterdam petitioned for the exclusive right to 
shave. But a trade profession so widely bifurcated Chap. II. could not survive the first generation in a new country. The settler probably shaved himself in preference to seeking a surgeon to do it, and the barber improved his social rank by putting away his razor and hone and setting up in his medical capacity only. As the higher ranks of the profession were mostly unoccupied, the very word surgeon as a professional distinction disappeared from general use in America. Every smatterer breveted himself physician to fill the vacancy. The so-called bonesetters, of whom we hear very early in New England, must have had predecessors in the mother country. Men with no professional training and little education, they appear to have been expert in the mere joiner work of surgery, as their title implies. The art was often transmitted from father to son, and was sometimes believed to be a natural and hereditary gift. In 1652 the Connecticut General Court employed one of these men for the colony. This appointment of a bonesettergeneral indicates the rarity of surgeons in the country when those of the first generation had disappeared. Six years later Boston felt some alarm at the number of people resorting thither for " help in physic and surgery," and took measures to prevent the town from becoming responsible for the support of any of these patients. Clayton gives an unflattering account of Virginia physicians in the latter part of the century. They were, no doubt, like all the colonial medical men of the time, mere 
ChaP. II.

Clayton in Force's

Tracts.

Note 30 .

Medical parsons and medical women.

Compare Forsyth, Antiquary's Portfolio, i, 36. country-bred doctors, with the training that could be got from an apprenticeship to the half-educated surgeons, their predecessors. Their standard remedy was "crocus metallorum," which indeed, says Clayton, " every house keeps, and if their finger, as the saying is, ake but, they give three or four spoonfuls; if this fail, they give him a second dose, then purge them with fifteen or twenty grains of Rosin of Jalap, afterwards sweat them with Venice Treacle, Powder of Snake Root or Gascoin's Powder." These failing, the case was given up.

\section{XVII.}

From remote times it fell to the lot of the priest, as the only educated man in the parish, to give medical advice; so that medicine was at one time almost wholly in the hands of the clergy and women. This medireval usage cast its shadow across the following centuries, and some of the clergy who came to America had a fair acquaintance with the medical knowledge of the time. Robert Paulet, who was sent to Virginia as a parson in I6I9, appears to have been highly esteemed as a physician; he refused a place in the governor's council because he could not be spared by the people of his region. Many of the ministers in New England practiced physic, some of them professionally, others apparently gratuitously. There were few educated men in New England or Virginia who did not keep a few medical books and 
perhaps prescribe for their neighbors. Women had for ages practiced medicine. The dependents in the country houses and the tenants on the estates in England and in Europe generally looked to the wife of the master for medical advice. The same conditions persisted until recently on the large plantations in the Southern States, where the mistress was obliged to have her little stock of drugs and her ready traditional rule of prescription for the ordinary maladies. Professional women physicians were not uncommon. In country places in England the "good woman," as she was called, still lingered; she was "a pretended physician, chirurgeon, and blesser." She claimed especial skill in counteracting the mischief wrought by witches and demons, and this part of her art was sometimes called "white witchcraft." Obstetric cases were wholly in the hands of midwives in the earlier colonial period. It was just about this time that Dr. Peter Chamberlen attempted to organize women practitioners of midwifery in England into a company, with himself at their head as president and examiner. As early as 1655 a midwife was officially appointed in New Amsterdam and a house erected for her. The same class of practitioners were in the other colonies, and it was with difficulty that physicians could acquire a portion of the obstetric practice at a later time. There was also a class of women practitioners in many places who did not confine themselves to any one branch of practice and who gave the officinal remedies of

CHAP. II.

Roy.

Comm.

Gawdy MSS., p. I 44 and others.

Roll of Royal Coll. of Physicians, $i$, I95.

Calendar of Dutch MSS., 148 . O'Callaghan, New Netherland, 155. Comp. Sewall's Diary, i, preface, xiii, and page 166.

Comp. Watson's Annals of N. Y., 205 . 


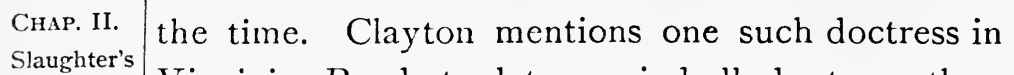
History of the Parish quoted in Anderson's

Col.

Church, iii, IIs.

Niles, French and Indian Wars, 3 . Mass. Hist. Soc. Coll., vi, 199 .

MSS.

Com. 14 Rep't, pt. ii, R.

Owen to $\mathrm{E}$. Harley, June, $166_{3} 8$. D'Ewes, Autob., i, 26.

Note 3 r.

Decline of medical knowledge.

Cireen's Medicine in MIass. Virginia ; Byrd at a later period alludes to another. There is a record that this latter, a Mrs. Livingston, of Fredericksburg, was paid a thousand pounds of tobacco by the parish of St. George "for salivating a poor woman, and promising to cure her again if she should be sick again in twe ve Months." In some cases like those of the famous Mrs. Hutchinson, of Boston, the services of a gentlewoman versed in obstetric practice were freely given to her neighbors; the professional doctress of Block Island at a later period was the wife of a rich man. The practice of general medicine by women prevailed in England at the time, and came down from it is hard to say what antiquity, for one of the most famous of all the medical professors of Europe in the eleventh century was a woman.

XVIII.

Colonial medicine declined in character from the beginning. The physicians of the second generation, like the magistrates and clergymen, had much less education than those who came from England. Besides their lack of general culture they had no proper training; the surgeon sent to Massachusetts in 1629 was obligated to take one or more apprentices to learn his art. This apprenticeship was probably all the teaching received by the native practitioners of the seventeenth century and the early eighteenth. It was 
complained, in 1647 , that medical students in Chap. II. Massachusetts were "forced to fall to practice before ever they saw an Anatomy made." The docThe same, 3 I. tors of America could hardly have ranked with the most rustic chirurgeons in England. As the first generation of the American born came on the stage, ignorant quacks and fanatics grew as rank as the English weeds that flourished in the forest mold of a new continent. "We ought by all means," says a Pennsylvania writer of 1684 , "to discountenance all Babylonical Letter-learned physitians both for the Soul and Body." The medicine of the age was bad enough at its best; worse than the Greek medicine whose traditions it revered and sometimes followed. The first influence of the chemical school had been mainly bad; it was only later that good results came from it. But the seventeenth century was none the less a century of advance; in that age modern scientific medicine was born. Harvey's discovery of the circulation of the blood is the starting point, not only of modern medicine, but of experimental science as well. His investigations on the subject of generation gave a philosophical basis to comparative anatomy, and thus broadened the field of human thought. In that century the skill of physicians first learned to cope with malarial disease as a result of the introduction of cinchona, the most important of all modern remedies. But the intellectual progress of the time was a narrow current perceptible in the mid-channel of a wide 
ChaP. II.

and sluggish river whose shore reaches were stagnant marshes and never-changing pools.

\title{
Elucidations.
}

Note I, page 50.

Note 2, page 50.

Note 3 , page 51 .

There is a pleasant sentence touching this rever $\checkmark$ e for the traditional in Harvey's lectures, in which he alludes to ne necessity for using the utmost precaution, because he is dealing with an error two thousand years old. "Hinc error 2,000 annorum pridem habitus quare egi obsequatis tabulis quia tam antiqua: a tantis viris culta." Prelectiones, 78.

\author{
But first they showed their high descent, \\ Each eldest daughter to each element, \\ Choler was owned by Fire and Blood by Air ; \\ Earth knew her black swarth child, Water her fair. \\ -Anne Bradstreet's Poems, 36.
}

There were other curious notions about the humors. For exam. ple, a physician, writing on Tunbridge water in 1670 , speaks of phlegm as "the private excrement of the brain at the mouth and nose." The opinion was no doubt generally held on the authority of Galen's Medical Definitions, in which the mucus from the nostrils is called "an excrement and sediment of the brain." Paré says phlegm is blood half concocted and is fit to nourish the brain. English edition, p. 9 .

This "numeral fetichism" may be plainly traced to Galen, and it is evident also in the theory of the "critical days" in disease which Hippocrates announced and which has been accepted in some form down almost to this day. See, for example, Aphorisms of Hippocrates, section ii, 24; iv, 59, 61, 64; and Adams's references to Galen on these in his edition. Sir Conrad Sprengell's comment on the former of these, in his English translation of the Aphorisms in 1735, shows the vitality of the notion at a late date. Conrad Sprengell reduces the days to periods, and he hesitates to accept the dictum of Hippocrates, that fevers are apt to return unless they leave the patient on odd days. Compare the short work that Kurt Sprengel, at a later day, makes of this very aphorism in his Apologie des Hippocrates, 1788. The ridicule of Molière has not missed a preciosity so delightful as this reverence for number. In the Malade Imaginaire the physician is asked how many grains of salt should be put into an egg. 
"Six, eight, ten," is the reply, " in even numbers, as the mediChap. II. cires are to be given in odd numbers." Act ii, sc. ix. Compare also what Philo Judæus says in eulogy of the number seven and its parts: Creation of the World, chap. xxx, and in chap. $x x x v$, his citation of an elegy by Solon the lawgiver, dividing life into ten periods of seven years. In the following chapter the division of human life by Hippocrates into seven periods is mentioned. This passion for numeration, thousands of years old, emigrated to America. Anne Bradstreet sings of The Four Humors in the Constitution of Man, The Four Ages of Man, The Four Seasons of the Year, and The Four Monarchies. The number four ran in the family; her father, Governor Dudley, wrote of The Four Parts of the World.

When the words of the text were written I did not know that Maurice Raynaud had remarked the same thing. " Il est digne Note 4, page 5 I. de remarque que la médecine humorale est restée celle des gens du peuple, dont la langage est si souvent ce qu'était deux cents ans auparavant, celui de la science." Les Médecins au Temps de Molière, I80, note. In I 580 Juan Huarte, a Spanish physician, published Examen de Ingenios para las Sciencias, a work of great popularity which was rendered into many tongues. The English version appeared in 1616 under the title A Triall of Wits. Huarte tried to do what modern phrenology has attempted-to indicate the aptitude of men for different occupations. In chaps. $v$ and vi he explains that all the difference in the character of men's minds is traceable to heat, dryness, and humidity. Dryness is favorable to understanding, heat to imagination, while moisture is essential to memory, which is therefore strongest in the morning.

In that strange series of notes which we know as Bacon's Natural History, the following remedies are mentioned as familiar cathartics and diuretics of that time : colquintidæ, agaric, black hellebore, scammony, antimony, mechoacan, rhubarb, senna, wormwood, myrobalanes, peach-tree bark, medicines of mercury, salt, oxymel, and pepper. Except mechoacan, peach-tree bark, and perhaps wormwood, all these remedies were known to the Arabians, and all the rest except senna, myrobalanes, and oxymel were, I believe, included in the ancient Greek materia medica. Compare Adams's Paulus Egineta, vol. iii, passim. Clysters and suppositories are mentioned by Bacon. It would seem that purgatives and their opposites were very important elements of Eng-

Note 5 , page 52. 
CHAP. II.

Note 6, page 53 .

Note 7 , page 55 .

lish medicine in the seventeenth century. Bacon repeats the jest of a famous Jewish physician, who said that English medical men were "like bishops that have the power of binding and loosing, but no more." Advancement of Learning, book ii. The use of cathartics to void humors that might send up vapors to the brain, recalls Vaughan's advice that one should sleep on the right side with the mouth open, and with a hole in the nightcap at the top. Fifteen Directions for Health, p. I3, 1602, Early ; glish Text Society.

Barrough's The Method of Phisicke directs in certain cases to draw blood out of the middle vein of the forehead, and in another case "you must cut the liuer veine on the arme." Third edition, I6oI, pp. 45 and 46 . I have also a copy of the seventh edition of this popular manual dated 1634. Its general use in America was probably matched by its authority in England. There is a round denunciation of the practice of venesection by an anti-Galenist in Thomson on the Plague, I666, pp. 50 and $5 \mathrm{I}$. Venesection was not nearly so common in England as in France. In the Historical MSS. Commission, Eleventh Report, Appendix, part v, p. 7, is a letter from Prince Rupert: "I am in noe small paine for our cosin since I heare she hath gott the small poxe. Pray God shee falle not into the Frenchifyed physician's hands, soe lett blode and dye."

That the doctrine of signatures is more ancient than Paracelsus I have no doubt. The treatise De Dynamdiis, usually enumerated among the works of Galen, and sometimes ascribed to Gariopontus, of the famous medical school of Salerno (a professed compiler from Galen), deduces the therapeutic virtue of substances from color, form, or other characteristics. Wuvres de Ambroise Paré, Introduction par Malgaigne, xxi. Compare also Henclerson's School of Salernum, ii. But the editor of Sydenham Society's edition of Paulus Ægineta has in part anticipated this remark, for he says that he has " detected a few traces of the singular doctrine of signatures, so-called, in the works of ancient authorities," iii, I6. Major J. W. Powell, Director of the Bureau of Ethnology of the Smithsonian Institution, tells me that the doctrine of curing by likes is a part of the medical theory of every tribe of American Indians, as it is very curiously of Chinese medicine. The conclusion is not a violent one that it is an element of primitive medicine generally. It was elaborated into an element of philosophy in the later middle ages. Basilius Valen- 
tinus, whose Triumph Wagen Antimonii, written about I 500 Chap. II. A. D., appears to have furnished Paracelsus with many germs of theory, pretends that a spider being poisonous can not get away if surrounded by a circle of unicorn's horn which was an ideal antidote to poison. But if any poisonous substance were added to the circle, the spell was broken and the spider escaped. Bread, on the other hand, was strongly attracted by unicorn's horn, both being free from poison, pp. 66 and 67, original edition, I624. His general principle is stated mystically-"Simile simili gaudet." Paracelsus probably derives from this his dictum "of likes with likes, not contraries against contraries" ("Ex qua recepta sibi proponuntur similium cum similibus non contrariorum ad contraria "), and he adds, "Salt therefore wishes to have its Salt, Mercury its Mercury, and Sulphur its Sulphur"-salt, mercury, and sulphur being the three principal elements in mystic philosophy. Paracelsus, De Cutis Apertionibus, chap. vii, p. 62. Compare Otto Tachenius, His Clavis, p. 2, and see the doctrine of the sympathy of similars stated with a ludicrous mimicry of logic by a learned Galenist, Maranta, in his De Theriaca, liber i, caput iii ( 1576 ). Adams, in his edition of the works of Hippocrates, i, 75 $\mathrm{ff}$., on the treatise anciently ascribed to Hippocrates and belonging to his period, On the Places in Man, says: "And he further makes the important remark that, although the general rule of treatment be 'contraria contrariis curantur,' the opposite rule also holds good in some cases, namely, 'Similia similibus curantur.'" Basilius Valentinus, p. 68, recognizes both methods as though this passage were before him, and Paracelsus appears to be denying the first half of it in the extract given above. It is not possible to separate this doctrine of curing by likes from the doctrine of signatures with which it was entangled. One of the best statements of this is to be found in the Magia Natural o Ciencia de Filosofia Secreta, a very intelligent work by Castrillo, a Spanish Jesuit, which bears date J649. He says that many " modern philosophers" have pretended to find in external forms indications of the occult qualities of things. Plants that show any resemblance to the human head are good for cephalic troubles, as are animals whose heads are remarkable in shape, such as the elephant, the beaver, and others. Animals with eyes notable in any way are remedies for the ills of that organ, and he instances among others the turtle that in dying was believed to shut one eye and open the other, and mentions a stone that showed a pupil within a circle which rendered the vision acute if held in 
Chap. II. the hand. The whole passage is interesting. Folios 16 and 17. The cure by similitudes is found in the treatment by amulets, and in that form is probably older than in medicine. There seems to be a trace of this mode of thinking in the ancient legend of Telephus, which has served so many poets, including Dante and Chaucer, and which gave anciently the name "telephean" to incurable ulcers. Wounded by Achilles, Telephus could be healed only by rust from the spear that inflicted the injury. A suggestion of the same feeling among the Semitic nations is perhaps to be found in the brazen serpent of Moses, and in the offering of the Philistines, I Samuel, vi.

Note 8 , page 55 .

From the English version of Jacob Behmen's De Signatura Rerum I quote the following: "Every root as it is in the Earth may be known by the signature for what it is good and profitable, ... and it is discerned in the leaves and stalk which Planet is Lord in the Property, much more in the Flower: for of what taste the Herb and Root is, even such an Hunger is in it, and such a cure lies therein, for it has such a Salt." Compare the term sulphur applied to rosin: "welchs des Baums Sulphur ist." Triumph Wagen, 230. There was a passion for the mystical and esoteric in science at the end of the middle ages. "Medicine," says Paracelsus, "is not otherwise a science than this that the will of God may be secret and secret may be the will of God." De Naturalibus Rebus, chap. v. Among the manuscripts in my collection is a very clever alchemical Poeme Sur l'elixir Royal in a handwriting of the late seventeenth century. In this, Nature, exhorting the poet to speak of the forces by which Heaven has extracted light from metals, enjoins him to speak esoterically "like a philosopher":

Parles, m-a-t-elle dit, de ces premiers agens

Dont la ciel des métaux a puise la lumiere,

Parles en Philosophe, afin que ma matière

Ne se laisse trouver qu'au plus intelligens.

Note 9, page 57 .

Bacon recommended the entrails and skin of a wolf for colic. A case recently occurred in the suburbs of New York city in which a mother administered boiled mice to cure a child of nervous timidity - no doubt a survival of some old English prescription based on "curing by the assimulate." Salmon, in his English Physician, 1693, p. 309, says, "The Flesh and the Liver of a Mad Dog dryed and beaten into Pouder are said to cure the biting of a Mad Dog." He prescribes the spleen of an ox for dis- 
eases of that organ, and the lungs of a fox for pulmonary diseases. Chap. II. The list of such remedies might be multiplied. In popular medicine yellow dock is still used for jaundice. In I 708 Lady Otway gives two recipes for curing jaundice made up mostly of yellow substances. In the one she put lemon, turmeric, and saffron; the other consisted of " 20 head-lice mixed with nutmeg and sugrar and powder of turmerick." Royal Historical MSS. Commission, Tenth Report, Appendix, part iv, 352.

Stafford appears to claim this as his own nostrum, but the process is given in Paracelsus, who no doubt found it in Basil Valentine, who differs from Stafford in the number of toads. One live poisonous toad-ein lebendige gifftige Kröte-is his prescription. The toad was dried in the sun and burned in a closed kettle, after which it was pulverized. He explains that calcination brought out the inner power or poison of the toad, which being applied, "like its like," drew out. Basil calls it a magnetic cure. Triumph Wagen, edition 1624,71 . See the allusions to this preparation in Emanuel König, Regnum Animale, 1683, 139, where various authorities are cited, and where a mode of preparing the toad for an amulet-nobilissimum amuletum-is given, following Paracelsus and the Basilica Chymica. On the medical uses to which the toad was applied in England compare History of Animals and Minerals, by Robert Lovell, Oxford, I66I, and Salmon's English Physician, I693. As an antidote to its own p jison the red toad was used anciently. See the authorities cited in Adams's Paulus Ægineta, ii, 207.

It must have been unfortunate to have a prescription of such value in controversy, but the authorities are not agreed as to its ingredients. Moss from the skull of a dead man, ari derelicta, was, however, a permanent element. Bacon gives some account of one prescription in his Natural History, section 998. But John Baptist Porta has the prescription given by Paracelsus to the Emperor Maximilian, and received through a courtier by Porta. I give it in English: Two ounces of skull moss, as above; of human flesh, the same; of mummy (a liquor reported to be clistilled from dead bodies) and of human blood, each half an ounce; of linseed oil, turpentine, and Armenian bole, each one ouncepound all together in mortar. Porta's Magia Naturalis, liber viii, caput xii. According to Porta, the weapon was left lying in the ointment. In the text I have followed a different prescription given in Bacon's Natural History. In the selection of ingredients

Note II, page 59. 
ChaP. II.

Note 12, page 59 .

Note $1_{3}$, page 60.

Note 14 , page 60 . for this preparation the mystical doctrine of curing by similitude is manifest.

"The operation of this ointment," says the author of a famous pharmacopœia, in $164 \mathrm{I}$, " is by the identity or sameness of the Balsamick spirit, which is the same in a Man and his Blood; for there is no difference but this, in a Man the Spirit actually lives, but in the Blood it is coagulated." Shröder, quoted by Salmon, English Physician, vii, 64. See also Sir Kenelm Digby's Sympathetic Powder generally, and a theory of the action of this powder, or "Zaphyrian Salt," in Howell's Familiar Letters. Jacob's edition, 645. An account of the cure of Howell by this remedy is in supplement ii, 673,674, and in Digby's A Late Discourse touching the Cure of Wounds by the Powder of Sympathy, 6-I I. The sympathetic powder was used for all hæmorrhages and even for other diseases, according to Sprengel. Compare Sir K. Digby on the cure of swelled feet in oxen, Discourse on Sympathetic Powder, I29-132. In the time of their greatest vogue these cures were probably never sanctioned by the strict Galenists. The subject was discussed before the Royal Society in its infancy in a paper intituled Relations of Sympathetic Cures and Trials. Sprat, 199.

Ambroise Paré, the famous surgeon, had the wholesome scientific-skepticism which was wanting in Lord Bacon and most other philosophers of the time. He denounced the weapon ointment as imposture. "Neither if any should let me see the truth of such juggling by the events themselves and my own eyes, would I therefore believe that it were done naturally and by reason, but rather by charms and Magick." Paré's works, old English version, 39. Paré also refused mummy, not knowing what it was made of. Compare the debate in the Glasgow Synod over the curative power of the famous Lee penny. Mitchell's Past in the Present, I 59.

Queen Elizabeth's ambassador to the French court in 1596 was attended in his illness by Lorrayne, a physician of the famous faculty of Montpellier, and another. "They gave him Confectio Alcarmas compounded of musk, amber, gold, pearl, and unicorn's horn," ingredients whose virtues seem to have been deduced from their rarity and costliness. The confectio alkermes, an Arabic remedy, varied in its ingredients. The amber was ambergris. See the formula in the Amsterdam Pharmacopœia of 1636, p. 61, and that in the London Dispensatory as quoted and 
discussed in Culpepper's Physitian's Library, 1675. The Arabic form of the confection appears to have been less complicated. In the well-known pharmaceutical work of Mesue the youngerJohn son of Mesue, son of Mech, son of Hely, son of Abdella, King of Damascus-the ingredients in this " confectione alkermes " are fewer, and there are no pearls or ambergris. The costly elenients are "good gold," "good musk," and lapis lazuli. My copy of this work is called Mesue Vulgare, perhaps because it is in Italian. It bears date Venice, 1493, and must have been one of the earliest of printed medical works. See K. Sprengel, vol. ii, $361-364$, on Mesue the younger. On the tendency to expensive remedies, compare Howell's Familiar Letters, 45. "More operativ then Bezar, of more virtue then Potable Gold or the Elixir of Amber." In Molière's Méclecin Malgré Lui, acte iii, scene 2, Sganarelle speaks of a medical preparation: "Oui, c'est un fromage préparé, où il entre de l'or, du corail, et cles perles, et quantité des autres choses précieuses." An English confection described by Bassompierre may have been the confectio alkermes spoken of above: "A pie of ambergrease magesterial, of pearl, musk," etc. Bassompierre's Embassy, 36. The bezoardick powder magisterial of the London Dispensatory contained sapphire, ruby, jacinth, emerald, pearls, unicorn's horn, Oriental and American bezoar, musk, ambergris, bone of a stag's heart, kermes, and sixteen other ingredients. "I am afraid to look upon it," says Culpepper. "'Tis a great cordial to revive the Body, but it will bring the purse into a consumption."

The application of a fowl freshly cut open, to cure erysipelas and other diseases, has been practiced in the valley of the Ohio and probably elsewhere within memory. Lorrayne, of the famous faculty of Montpellier, in his treatment of the English ambassador referred to above, made use of " pigeons applied to his side, and all other means that art could devise sufficient to expel the strongest poison and he be not bewicht withal." MSS. at Hatfield House, vi, I I2. Manuscripts Commission. "I never heard of but one person bitten in Pennsylvania and New Jersey with the Rattlesnake," says Budd, " and he was helpt of it by two chickens slit assunder and apply'd to the place, which drew out the Poyson." Gowan's edition, p. $7 \mathrm{r}$.

Gold is said by the alchemist to have its origin in the sun. It is called " the under sun," and " an earthly sun endowed by God with an incredible potency, for in it are inclucled all vegetable, animal, and mineral virtues." Potable gold is the "tincture of

Chap. II. 
Chap. II. the sun," and the enthusiastic Glauber talks of " partaking of the fruit of the Sun tree." Compare Phaedro and Glauber passim. A large volume would not be sufficient to recount all the virtues of this powerful remedy, in Glauber's opinion. Compare Evelyn's Diary, i, 271 .

Note 16 , page 6r.

The curious and scientific reader may follow if he can the process for making potable gold, the "True tincture of the Sun," in the various works of Glauber, or in De Via Universali he may learn to get both potable gold and the philosopher's stone by " the dry process " or by " the wet process." He may get directions for making the tincture in Glauber's De Auri Tinctura sive Auro Potabili, a German work with a Latin title, dated 1652. Or he may read the Panaceæ Hermeticæ seu Medicinæ Universalis of Johann Gerhard, I640; but he will find the " most secret mode of compounding the Universal Medicine" in the Arcamun Lullianum. There is a rare tractate, Vom Stein der Weisen, written in the middle of the sixteenth century, by Phaedro von Rodach. These and others are before me, but, after some wearying of the mind with esoteric phrases in a compound of old German and Latin, I prefer to leave the question of the actual constitution of the most potent universal remedy to special investigators. Fonssagrives, in the Dictionnaire Encyclopédique des Sciences Médicales, under the word "Or," says that a preparation of mercury and chloride of gold constituted the so-called potable gold of the seventeenth century-I do not know on what authority. I am in some doubt whether, after all the complicated hugger-mugger, the alchemists got any gold in their final decoctions. According to Phaedro, it was not so much gold they sought as the subtile spirit of gold that freed men and metals from impurities. Glauber, in his De Auri Tinctura, 1652, took pains to explain how the true could be known from the false and sophisticated potable gold, some of which was nothing but colored water, p. 24. Angelus Sala, though of the Paracelsian school, ricliculed the notion of drinkable gold, and declared that fulminating gold (knallgold) was the only preparation of that metal that had ever been made. Sprengel, Geschichte der Arzneikunde, iv, 557. It has been conjectured that some of the so-called potable gold offered for sale was merely a preparation of mercury. The two metals were allied, in the fancy of the time. In the Ehralter Ritterkrieg Gold calls Mercury “Mein Bruder Mercurio," and yet says that mercury was the female and gold the male. Salmon's English Physician, p. Io, has two recipes for making tincture of gold, one 
with, the other without mercury. More than one writer intimates that there is as much gold left after the liquid essence is drawn off. "Aurum decoctione non atteritur," says Lemnius. But the mere looking at gold coins or at rings, especially if adorned with "stones and lovely gems," recreated the eyes and heart, and a man might be brought to himself when in a collapse by applying gold and saffron to the region of the heart with the third finger of the left hand. Lemnius, Occvltis Naturæ Miraculis, 309, 310.

An English manuscript in my possession in the handwriting of the seventeenth century gives many directions for alchemical processes to attain the "quintessence" so much sought. Some of these had to be conducted in the earth. Under the title The Essence of wine whereby to Dissolue Gold this occurs: "To the Essence of wine twice circulated (as is elsewhere taught), add (rold \& Sett it in digestion in Sand wth a Lamp For 3 months \& yu shall finde the Gold dissolued but not irreducibly, never the lesse a quarter of a Spoonfull given at a time to a dying man, tho he be insensible, it will restore him half an hour to perfect sence, as ever he was in all his life."

The library of Winthrop the younger consisted of more than a thousand volumes. The fraction of it now in the Society Library Note 18 , page 62. in New York is less than half. Among these is Hercules Chymicus sive Aurum Potabile, I641, and Traicte de la Vraye Unique Grand et Universelle Médecine des Anciens, dite des Recens, Or Potabile, 1633 . There was also Glauber's Latin Treatise of 1658 on Potable Gold. These were new books. The revival of interest in potable gold in the seventeenth century awakened opposition. Burton, in his Anatomy of Melancholy, says: "Some take it upon them to cure all maladies by one medicine severally applyed, as that Panacea, Aurum potabile, so much controverted in these days." In $\mathrm{I}_{403}$ an English statute had been passed making it felony to "use any craft of multiplication " to increase the quantity of gold and silver. Statutes at Large, ii, 448. Robert Boyle, in the serenteenth century, in spite of his having written The Sceptical Chemist, thought he had discovered the forgotten secret of the fifteenth century, but he did not print his discovery. Sir Isaac Newton wrote to the Royal Society in praise of Boyle's reticence, fearing that the full disclosure of what the hermetics knew was " not to be communicated without immense damage to the world." In 1689 , however, Boyle secured the repeal of the statute forbidding the making of gold. Thus did the dark

Chap. II.

Note 17 , page $6 r$. . 
Chap. II.

shadow of mediæval credulity still fall upon the most enlightened minds. Compare Chalmer's Dictionary of Biography, vi, 348, 349.

Note 19 , page 64 .

The multitudinousness of ancient compounds was perhaps a trait derived from primitive medicine. The Iroquois had a sort of theriac, a cure for all bodily injuries, made from the dried and pulverized skin of every known bird, beast, and fish. Erminnie A. Smith, in Powell's Second Bureau of Ethnology Report, 73.

Note 20, page 65.

"In that country [Java] but very seldome there grows a Stone in the Stomach of a Porkapine, called Pedro Porco: of whose virtue there are large discriptions: and the Hollanders are now so fond that I have seen 400 dollars of $\frac{8}{8}$ given for cne no bigger than a Pidgeon's Egg. There is sophistication as well in that as in the Bezoar, Musk, \&c., and every day new falsehood." Sir P. Vernatti, in Sprat's Royal Society, I7I. There was exhibited in the University of Leyden "the horne of a goat in whosse ventrikle the bezar stone is found." Marmaduke Rawdon, Camden Society, 105. Compare the accounts in Monardes and Acosta and the discussion in Castrillo's Magia Natural, last chapter. Castrillo calls the bezoar "Regna de los Venenos," and says that it cured pestiferous fevers and other diseases caused by melancholy humors. Joannes Juvenis, in his essay De Medicamentis Bezoardicis, published in Antwerp in the latter part of the sixteenth century, treats the bezoar very mystically. A disease of an occult and divine origin-divinus et Secretus morbus-like the plague, exacts a medicine of a heavenly and concealed faculty, and, as he said, with a blind and hidden potency. The plague, he says, "is a mysterious disease of the heart caught by inhalation from poison dispersed in the air by a malign conjunction of the planets." It requires a bezoardic remedy. Under this head he includes alexipharmical mixtures and remedies whose supposed virtues have no rational basis, as well as amulets. $\mathrm{He}$ describes an amulet of gold, silver, and arsenic made into the shape of a heart and worn next that organ by Pope Adrian, and he recommends the wearing of six precious stones and some brilliant pearls in finger rings or about the neck. They are to be frequently looked on, for in them resides "the hidden bezoar" against all poisons and the plague. There is here the sense of alexipharmical in the word bezoar. Compare the citations of Adams in Paulus Ægineta, iii, 247. Beguin's Élémens de Chymie, edited by Lucas de Roy, 1632, describes seven kinds of "bezoart "- to wit, mineral, solar, lunar, martial, jovial, metallic, 
and solar of Harthmannus. None of these have anything to ChaP. II. do with the bezoar stone. Paré says that it is called by the Arabians bedezabar. But he quotes Garcias ab Horto as saying that the goat is called pazain, wherefore the stone should be called pazar. Paré's (Parey's) works in English, book xxi, chap. xxxvi.

The colonists were cut off by distance from that most potent remedy for king's evil, the royal touch, by which thousands of English people were healed, and the administration of which the Church of England sanctioned by a form of prayer. See in Sparrow's Collection, 1671. In I684 six or seven people were literally crushed to death in the mad eagerness of the crowd to secure the blessing of the royal touch. Evelyn's Diary, 571. It is remarked by Aubrey with his wonted innocency that "whether cur kings were of the house of York or Lancaster" the touch "did the cure (i. e.) for the most part." Worse than all, in the time of Monmouth's rebellion, the illegitimate touch of the pretender cured some of his believing partisans. Castrillo, the Spanish Jesuit, declared in 1649 that the intercessions of Joseph of Arimathea, the first missionary to England, had secured to its monarchs " el cura de la gota." The Spanish kings, on the other hand, had the gift of exorcism. "Los reges de España tienen gracia de ahuyentor demonios por auer sus antecessores professado la propagacion de la Fé," etc. Magia Natural, folio 81. The miraculous touch of the English kings was believed to date from the Confessor. The touch of a seventh son- "a seventh son and no daughter between, and in pure wedlock "-was almost as good as the king's perhaps. Aubrey's Miscellanies, fourth edition, 124, 125. Seventh sons were to be reached in America sometimes. Faith in the virtue of their touch is not yet quite extinct in America or in England. Compare Diary of Walter Yonge, I3, note. In I688 a man afflicted with ulcers petitioned the Governor of Massachusetts to give him a brief to solicit money in Massachusetts to defray the expense of a trip to England to crave the royal touch. Green's Medicine in Massachusetts, 48.

I am indebted to Miss S. F. Price, the well-known botanist of Bowling Green, Ky., for technical information regarding dittany. The authorities on dittany are too numerous for citation. Virgil perpetuated the memory of the wild goats of Candia, and old medical books continued to refer to them. See Parés works in English, I600, p. 41 .

Note 22, page 68. 
Chap. II.

Note 23, page 68.

Note 24, page 69 .

Note 25, page $7 \mathbf{r}$.
As early as I 568 André Thevet's New found World or Antarctike appeared in an English version. Although quite vague, and on many accounts untrustworthy, it probably awakened curiosity regarding the medicinal value of American plants. The far more significant and much-esteemed work of Monardes, a Spanish physician, was probably read in England on its first appearance in Spanish in 1565. Fourteen years later, in 1577 , the first English edition was issued, and its influence can be traced in the account which Hariot gave of Virginia in De Bry. Through Monardes the English public first became familiar with the extraordinary medicinal virtues attributed to tobacco, and in his pages sarsaparilla and sassafras, strongholds of quackery to this day, were first made known to a public that soon became enamored of two plants which had the virtue of innocuousness. In the estimation of Monardes the "leaves, plants, herbs, roots, blossoms, gums, fruits, seeds, liquors, and stones of great medicinal virtues" which had come from America were of as much greater value than all other wealth of the New World as " bodily health is worth more than temporal good." First Spanish edition, 1565 , p. 3 .

Books of reference and most writers on Virginia confound John Clayton, author of various papers in the Transactions of the Royal Society, with Clayton the botanist, whose observations in the eighteenth century supplied the foundation for the Flora Virginica of Gronovius. A writer in the National Dictionary of Biography, with bibliographical detail, ascribes all the writings of John Clayton, the seventeenth century clergyman, to John Clayton the botanist in the eighteenth century, making the latter the precocious author of papers published five years before the date of his birth as given in the same work. John Clayton, the parson, was also the author of a posthumous paper in volume xli of the Transactions of the Royal Society. Neill calls him "the parson of Jamestown," but, so far as I know, without any authority.

I am unable to identify the little creatures found on oak leaves which proved a remedy in some diseases when worn about the neck in taffetie bags by New England women. Josselyn's Two Voyages, 63. Increase Mather gives a popular cure for ague in New England, aimed at its periodicity. Five pieces of bread having letters written on them were given into the custody of the patient, who was to write in succession on one of these 
exch day the word kalend (ant) for five days. Toothache was cured in Boston by giving a sealed piece of paper on which was written, "In nomine Patris, Filii, et Spiritus Sancti, preserve thy servant," etc. Illustrious Providences, I85. In Queen Elizabeth's time there was a curious remedy, which is alluded to as follows :

Gellia wore a velvet mastick-patch

Upon her temples when no tooth did ach.

-Hall's Satires, vi, i.

A belief in the value of perfumes for sickness, and especially for the plague, prevailed in Elizabeth's reign. See Bullein's Dialogue against the Fever Pestilence, passim, and the remark of Mulcaster on perfumes: "It is wonderful that is written and strange that we see, what is wrought thereby in nature of Physick, for the remedying of some desperate diseases." Positions, 37. I have not chanced to note anything of the sort in the seventeenth century writers, whose nostrums were far from sweetsmelling.

The curious reader may consult on the use of animal substances the regular pharmacopœias of the time. See also such works as Emanuel König's Regnum Animale, and in particular his chapter De Insectorum in Medecina utilitatibus. Culpepper's Commentary on the London Dispensatory, I675, contains lists of these animal substances in undisguised English. Cotton Mather said of Wait Winthrop, the third of the family to practice medicine on his neighbors, that he turned nearly all Nature to medicine:

Et pene omnem Naturam fecit Medicam.

Clayton, in the Transactions of the Royal Society for 1687 , xli, I 49, describes the Indian method curing wounds by sucking them and then using the mouth as a syringe to inject a biting decoction. Instead of cupping, the savages cauterized with lighted punk.

The practice of surgeons was not held in high esteem in England in the sixteenth and seventeenth centuries. John Halle, in the preface to Lanfranke's Chirurgerie, I 565 , says: "Whereas there is one Chirurgien that was apprentice to his arte, or one phisicien that hath trauayled in the true Studie and Exercise of Phisique, there are tenne that are presumptious Smearers, Smaterers, or Abusers of the same, yea, Smythes, Cutlers, Carters, Coblers, Copers, Coriars of lether, Carpenters, and a great rable of women, which forsake their handle Craftes and for filthy lucre
ChaP. II.

Note 26 , page 72. Note 27, page 72.

Note 28 , page 73 .

Note 29, page 74 . 
Chap. II. abuse Phisick and Chirurgerie." After lauding the medical profession, Peacham says: "I here intend no common Chirurgians, Mountebanks, unlettered Empericks, and women-Doctors ... whose practice is infamous, Mechanick, and base." Compleat Gentleman, II. See in Malgaine's Introduction to Paré's works, pp. 124 and $138 \mathrm{ff}$., decrees and ordinances for the regulation of barber-surgeons in the middle ages, with an account of the struggle of the surgeons to abase the barbers. In England matters had come to such a pass in the sixteenth century that Sir $\mathrm{H}$. Gilbert, in his Queen Elizabeth's Achademy, says that "Chirurgie is not now to be learned in any other place then in a Barbors Shoppe." To the practice of barbers, and surgeons little better, the colonists were usually shut up by circumstances. One early Virginia surgeon was a Dutch bond servant. A library consisting of The Surgeon's Mate or of Barrough's Method of Phisicke, rarely of several books, gave the suffering what comfort can be had from quackery that is self-reliant from mere ignorance.

Note 30 , page 76 .

Crocus Metallorum, the favorite Virginia remedy, was an officinal preparation used in several formulæ by Sydenham at that time. The editor of the works of Sydenham (Sydenham Opera Omnia, I 844) makes it "Antimonii Sesquioxyd cum Antimon. Sequisulphur." It was emetic. See Sydenham's Epistle I, works in English, ii, I9. It was prepared according to the London Dispensatory by calcining together equal parts of antimony and saltpeter. On the use of sulphuret of antimony by the Jews, Greeks, Romans, and Arabs, see an interesting note in Adams's Paulus Egineta, iii, 356. The curious reader may also consult Basil Valentine, p. 37, who makes antimony "one of the seven wonders of the world." The tract Von den Particular Vnd Vniversal-Tincturen, appended to the Triumph Wagen, Thölden's issue, I624, contains a section "De Crocis Metallorum, et eorum Salibus," written in alchemical style. Venice treacle was the world-famed theriac, which, according to the English formula, contained about sixty-five ingredients, and was given as a universal antidote. Gascoin's powder was the compound powder of calcined crab's claws, so called. I do not know what it was, but not literal crab's claws. Snakeroot is the only American remedy in the list, and this had been accepted in Europe. Evidently the Virginia doctors were old-fashioned, and, according to their slender knowledge, Galenist. Medicines of the other school and simples were perhaps used in domestic and irregular practice. 
Forsyth's Antiquary's Portfolio, i, 36, has the broad statement that in the Heptarchy and to the time of Richard II physic was in the hands of old women and the clergy. It was taught in the nunneries to girls before the Reformation as a womanly accomplishment, ibid., 238. The sense of its appropriateness to women, and the habit of prescription by accomplished women, survived in the seventeenth century and later. Clayton said of the Indians in 1687, "Every one according to his skill is a doctor (as some women are in England)." Transactions of the Royal Society, xli, 143. Tiraboschi, in his Storia della Litteratura Italiana, iii, lib. iv, sect. ii, cites from Odericus Vitalis a passage implying that the most skillful physician in the world-famous school of Salerno in 1059 was a woman. Of Rodolfo he says: "Nella medecina ancora egli era cosi versato, che in Salerno . . . non si trovo chi es uqualiasse fuor di una dotta matrona." This is supposed to refer to Trotula, some of whose writings have come down to our time. The wording of the decree of $128 \mathrm{I}$ cited in Astruc's Histoire de la Faculté de Médecine de Montpellier, p. 20 , is considered by Malgaigne to imply the habitual practice of medicine by women in the middle ages. In this decree Jacques " defend . . . à toutes personnes tant aux Chrétiens qu'aux Juifs," to practice without degrees. Compare Malgaigne's inference from this in his preface to Euvres d'Ambroise Paré, but Malgaigne's reference to Astruc and his date are both slightly inaccurate. On the women professors of the school of Salerno, Henderson's pamphlet on that school and Ordronneaux's Code of Health of Salerno. As late as 1691 Cotton Mather, in "Ornaments for the Laughters of Zion," mentions " chirurgery" as an appropriate study for women. It is said that in colonial New Jersey women engrossed a considerable share of the medical art, such as it was. This is no doubt true of all the colonies.

ChaP. II. Note $3 \mathbf{r}$ page 78 . 
CHAPTER THE THIRD.

MOTHER ENGLISH, FOLK-SPEECH, FOLK-LORE, AND LITERA TURE.

I.

Chap. III. AT the beginning of English emigration to The language of the time.

America the language was the narrow speech of an island people not much given to foreign enterprise. This stay-at-home tongue was very different from the comprehensive English spoken now in many climes and antipodal countries, and heard more world-widely than any other language since speech began. It is the implement of two most powerful, adventurous, and versatile peoples. Then

Note I. it was held in contempt of scholars, who preferred to use imperial Latin, which made the learned men of Europe one nation and distinguished them from the vulgar. Long after the religious unity of the Western world had ceased, the Roman Empire dominated the language of philosophy and law and religion. English was an insular speech, but it was not by any means the language of the whole island. To the Scottish Highlanders and to the Welshmen it was a foreign tongue; Cornishmen had violently Diary of opposed the Reformation mainly because they W. Yonge,
Camden Soc., p.xiv. their Bible printed in English, to them a jargon 
more unintelligible than the Latin they had been wont to hear in church from childhood. Even in what may be called English England the language was everywhere cleft into dialects and subdialects. It was still a matter of discussion where standard English could be found. The rugged forms of the shires north of the Trent were accounted the purer English; there the language had absorbed a smaller number of French and Latin words than it had in the south. On the other hand, the speech of London and its environs was preferred, because it was "more courtly and more current." This courtly speech, the language of poetry and the playhouse and the forerunner of our modern English, prevailed in the region that lay within about sixty miles of London "and not much above." There were gentlemen in all the shires that could "speak good Southerne," but most of the gentlemen and men of learning - the "learned clarkes," as they were called-habitually spoke the dialects of the common people of their counties. Even the "good Southerne" of the court was not yet fixed by rule, but was in a state of flux. This gave an advantage to the writer of first-rate power; he might select from the varied and ever-varying storehouse of common speech, and even from homelier dialect sometimes, such vital words and vivid proverbial phrases as fitted his thought. He could bend the yet supple language to his purpose untrammeled by conventional restraint and without. fear of the grammarian. The language has never been more

Chap. III.

Compare also Symonds's Diary, Camden Society.

Note 2.

Putten-

ham's Arte of English Poesie, I589.

Note 3 . 


\section{The Transit of Civilization.}

Снар. III. fresh and effective than it was in the hands of the masters of the Elizabethan time. But the great body of writers, being men of mediocrity, found in it no well-worn grooves through which commonplace utterance might flow smoothly without expert guidance.

\section{II.}

The exigency of English.

Puttenham's Arte of English Poesie, A. D. $15^{8} 9$. Arber's ed., 158 .

Note 4 .

On the side of poetic and imaginative expression English had been enriched before the sailing of the first Virginia emigrants, and it was further enriched in the years immediately following, chiefly through the drama and prose works in theology. But almost the only refining and enlarging influence of that time of literary activity that reached the speech of the common people, to which class most of the emigrants belonged, was the authorized translation of the Bible, which was published in 16II, and which by degrees took the place of the older and ruder versions. The language may have acquired something from the sea ventures of the time to Turkey and Russia and the Spanish main. "Secretaries Marchaunts and trauailours" were already introducing alien words, but England possessed little foreign commerce and did not yet promise to take rank as a sea power. The sudden demand upon this close-cabined island speech in the seventeenth century for means to represent the endless objects, actions, and experiences of the New World and of a widening commerce was one of the most efficient forces for developing modern English. 
III.

A language carried into a new environment brings with it preconceived notions not in harMisapprehensions mony with the surroundings; the ideas that are imbedded in our ordinary speech seem to us a part of the original constitution of the universe, and the traditional notions associated with common words serve to fortify local and national prejudice. In the wilderness of America English speech was a misfit; an Indian chief, however squalid and beggarly, was forthwith translated into a king; the stark-naked little squaw child Pocahontas, turning herself into a wheel in imitation of the boys with whom she played at Jamestown, bore in English the incongruous title of princess. We hear of an "Indian king" in New Jersey who was hired to carry a traveler's baggage ; and after encountering many scrubby royalties, it is a relief to find in New England one chief who was only a duke. The early adoption into colonial speech of the discriminating Indian titles - werowance, sachem, sagamore, and cockerouse-and the application at last of the generic English word chief, helped to dissipate a swarm of erroneous notions. More specific terms were the result of fuller knowledge; the compound bark house in which an "emperor," like Powhatan, dwelt as co-tenant with numerous families of his wife's totem, ceased to be a palace and became a wigwam. It was thus that English by degrees adjusted itself to a new environment. 
Chap. III.

Naming the animals.

For example, Clayton, in Miscell. Curiosa, iii, 338 .

Comp. A Perfect Description of Va., I649. Statutes of S. C., I726. W. Bartram's Travels, 46 .

Perfect Descr. of Va., I649, and Bullock's Va., I649, p. 6. Josselyn, iii, Mass. Hist. Coll., iii, 278 . Campa-
IV.

The settler in America, like Adam in the newmade world, was called upon to give names "to the fowl of the air and to every beast of the field." This was done in some cases most naturally by descriptive epithets, such as bluebird, mockingbird, catbird, canvas-back duck, flying squirrel, black bear. But the newcomer was sure to think he recognized in the primitive woods the plants and birds and beasts known or half known to him in the Old World. American creatures thus got second-hand names from real or supposed resemblances. The bison became a buffalo; the plantigrade raccoon does duty in some accounts as an ape or a monkey; the puma, as the largest American cat, became a "lyon" in Virginia, a panther and a catamount in various places, while it remained a "tyger" in South Carolina for more than a hundred years. The ear of the homesick emigrant caught the melody of bird songs that reminded him of the delicious vespers of the nightingale which he was nevermore to hear. Various birds were thus brevetted with the name of the European songster. In Virginia this substitute nightingale was the voluble redbird, according to Clayton, though in earlier lists both redbird and nightingale appear. In New England there were also so-called nightingales " painted with orient colorsblack, white, blew, yellow, green, and scarlet," according to Josselyn's multitudinous description. 
The Delaware region had its nightingale. The brown-throated song sparrow is unhesitatingly identified with the nightingale of Europe by French Chap. III. nius, New Sweden, Canadians to this day. With one accord English settlers north and south endowed a migratory redbreasted thrush with the name and all the traditional sentiment that belonged to the smaller and more domestic "robin redbreast" of England. The mistake did not go unsuspected, for in some northern regions there is an attempt to rectify it by calling the Baltimore bird "the old-England robin," a name that misses the mark again, but that from its form must have been set agoing in the earliest colonial time.

v.

In popular thought at the period of American settlement every place beyond the countries of EuThe turkey. rope was a region of outer darkness dominated by devils who were worshiped as deities. The typical infidel was the Turk, the ancient foe of Christendom ; an idol was therefore called a mawmet, that is to say, a Mahomet, from a notion that the Arabian prophet was a false god. It may have been from this general confounding of all the world that lay without Christendom that some plants and animals from the New World easily got the name of Turkey or Turkish attached to them. The fowl we call by that name was in French a coq $d$ Inde or Indian cock, whence the modern French dinde and dindon. The confusion between the East and 
Chap. III. West Indies led no doubt to the curious German

Pennypacker's

Historical Sketches, r 88 .

Note 5 .

Note 6.

Indian corn and beans.

Lane to

Walsingham.

Sainsbury's Calendar, i, 4 .

Acosta, Hist. Nat., etc., 1. iv, chap. xvi. name "Calcutta hen," though even in German "Indian cocks and hens" appear. In England the turkey was sometimes called the Indish peacock or the "peacock of Inde" in the sixteenth century, so that the peacock pies on which judges and others were sometimes feasted at the time may have been concocted of turkeys. If the English name of turkey did not come from a general disposition to trace all outlandish things to the home of the Eastern infidel, it perhaps was borrowed from the bustard, with which the turkey was suposed to be allied in the easy natural history of the time.

VI.

Indian corn, an American plant in origin, cultivated throughout almost the whole western hemisphere, was early called Turkish corn by the Italians. The name seems to have been transplanted from Italian into other Continental languages, and in English speech it was also sometimes Turkish wheat. Ralph Lane, Ralegh's commander in North Carolina, calls it "Gynneye wheat." From the time of Acosta there have been those who have sought with futile ingenuity to deduce an Oriental origin for maize, founding their argument mainly on the blunder in the Italian name. This prolific mistake may have sprung from a confusion of maize with buckwheat, which on account of its Asiatic origin bore the name of Saracen corn. Maize, 
as another sort of coarse grain, was also called Saracen corn, but usually Turkish corn. Other nations were wont in the sixteenth century to take fashions of all sorts from Italy, and the name there given to maize became common. Even the kidney bean, which was one of the most valued contributious of the American Indians to European food products, was called the Turkish bean, for no other reason perhaps than that it twined about the socalled Turkish corn. It was mistakenly identified with the "Turkish garavance," the chick pea. The word maize did not come into use in the English colonies; a letter of the Virginia Company calls the plant "maes" and "mace" ; but maize remains to-day only a book word in America. In I65 I a Virginia writer calls the plant Indian wheat, and later it appears as Virginia wheat. It gradually came to be called in all the colonies Indian corn, to distinguish it from other cereals. The natural abridgment of the word in popular use has made the generic word corn stand for a particular kind of corn unknown in England. In New England, where the phrase English corn long survived, the other end of the word was dropped, and "Indian" very early came to stand for maize even after it Comp. John Hull's Diary, 22I. had been ground and cooked. Grotesque combinations like "fried Indian" have lingered in dialect to our time. The season for reaping the familiar English grains was called by the emigrants the English harvest, the later ingathering of maize was the Indian harvest. From this distinction, perhaps, Note 9. 
CHAP. III.

The parts of maize and dishes made from it.

Virginia Britannia, p. 1 II.

came the name Indian summer for the season of balmy weather that befalls in the autumn when a halcyon stillness pervades the hazy air and the whole landscape lies enchanted. The name was probably of merely agricultural origin, but is nowadays full of poetic associations with the delicious season and a vanished people.

VII.

Indian corn became the staple food product of the colonists, and English was put to all its makeshifts to find names for its parts and products and the novel processes attending its culture and uses. Stalk, blade, and ear were easily transferred from other sorts of corn, but for the blossoms the words silk and tassel were felicitous tropes. The envelope of the ear gave trouble. Megapolensis, an early Dutch writer, calls the husks "leaves." Strachey, in speaking of "a kind of wheat" which the Indians call "poketawes," describes the ears as growing each "with a great hose or pill about it." The Virginians applied an English dialect word, "shuck," to the "hose" about the ear, the New England colonist adopted husk, and in the extreme South the infelicitous phrase "corn trash" came into use, and all three are still living. Husk, which in New England expressed the outer covering of the ear, was in the middle and in some southern regions quite as fittingly given to the bran, the covering of the grain, while in certain regions of Virginia the same word, usually pronounced 
" huss," meant the cob on which the grains grew; ChaP. III. nor is this use yet obsolete. This cob was at first called "the coare of the ear," the word cob was in New England at first used for the whole ear, as it was in English dialect for ears of wheat or barley. It has at last come to mean in America the spike Comp. Mather's Illustrious Providences, $x_{3}$, ed. 1850 . on which the grains stand. In all this effort of the English language to stretch its vocabulary to embrace the new plant and its parts it strangely disdained to borrow a word from the Indian tongues. But when we come to the dishes prepared from maize, the Indian words incorporated in our speech are living witnesses to the adoption of aboriginal cookery. Bread was called ponap in the dialect of the James River Indians; from this word we get "pone," variously applied in American English to several sorts of maize bread. Ustatahamen, a name for the grits or coarser parts of the crushed corn, gives us the word hominy. Samp, supawn, succotash are Indian dishes which brought their ancient names with them as a convenient mode of distinguishing them from food preparations of other cereals.

\section{VIII.}

The animals were not easily fitted with English titles; their skins and flesh were objects of trade between the two races, and many kept a semblance of their ancient names. The Virginia mussascus of Captain Smith is the

Smith's Oxford Tract of 1612.

Compare Sot-weed Factor, I 708. Shea's reprint, 5 .

Note ro.

American animals.

Tract of r6r2.

Civet-scented musquash smelling ever, of New England poetry, and his skin appears by 
Chap. III.

Wood's

Prospect.

Claypole's MS. Letters. Penn Hist. Society. British Empire, i, 187.

Purchase,

945.

Perfect

Description of Va. Clayton to Royal Society. Compare Smith's Tract of 1612.

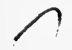

Note II. this title in the dull prose of English custorns returns. A Pennsylvania form, "musquasses," appears to be midway between the Virginia and the New England names. With a gravitation toward English forms the word is musquagh in Oldmixon, but it changed more swiftly in America; it was sometimes muscat, a name given to the civet, and as early as I649 it was "a muske Rat so-called for his great sweetnesse and shape," as though the Indian original had been forgotten. As early as 1688 Clayton called it mush-rat, a form still generally used in rustic speech. Other Indian words put on bits of English toggery; matchcore was $a^{*}$ word in Algonkin dialects meaning a deerskin. When the Indian accepted a colored blanket from the white man in exchange for his matchcore, he gave the same name to his blanket. The colonial trader was impelled to put a semblance of sense into the word by calling it matchcoat, and the word in this form was widely used by the colonists. Copyists of old handwriting, not suspecting that it was only a blanket, have made it watch-coat, and in this misleading, form it will puzzle posterity in Irving's prose. The general repulsion to the use of aboriginal words was no doubt increased by the polysyllabic prolixity of the agglutinated vocables that gave stateliness to the intervals of utterance with which a savage broke the monotony of his native taciturnity. Indian words were unhandy vehicles for the ideas of a colloquial and gossiping race. Usta- 
tahamen had to be reduced to hominy to match ChaP. III. the corresponding English word furmity, applied at first to corn. Pawscohicora was split through the middle to get the English word hickory, and the last syllable of isquontersquash was all that could be transplanted into New England English. Chechinquamen was a hard nut in English mouths until the Virginians made it chinkapin. Wampumpeak, the Indian name for white shell beads used for money, was divided; wampum passed current in one region, and peak or peague in another. The New York Dutch called the shell money sewant from another Indian word, while Virginia shell beads were known as roenoke from the Indian rawrenock. In the course of traffic and friendship between the two races a sort of pidgin English was formed as a medium, a half-breed speech only partly intelligible nowadays. Certain words of greeting, like "netop," friend, came into temporary use among the colonists along with honorary titles of leadership, such as the "cockerouse" of Maryland and Virginia, and the "mugwump" of parts of New England. Much of it was See example in Ames's Almanac, I730. local and temporary, and the residuum is small. To-day the English language, with the tolerance of a cosmopolitan, begs or borrows from barbarous sources the world over, but the home-bred speech of the period of American settlement seems to have cherished fastidious prejudices against foreign words without Latin ancestry to back them.

E. g., Sotweed Factor, 19. Note 13. 
Chap. III.

Engl:1sh d..alects.

Table-talk, I61.

Doc. Hist. of N. Y., i, 678 .

Dorch.

Records, I6 33, p. 3 .

Private letter from I)r. S. A. Green.

IX.

The absence of a well-established standard for English speech in the early Stuart period produced confusion in the colonies. Travel was not frequent between the several parts of England, and local feeling had the intensity of patriotism. Selden tells us that societies of men from a particular shire were formed in London. The men from a given county might thus allay the homesickness of their exile by meeting those who held to the same customs and sauced their speech with the same local words and accents. When an American region, larger or smaller, was settled by a body of emigrants from the same English neighborhood, many of the words and much of the twang of their ancient dialect would survive for generations. We have here a probable explanation of a marked difference of speech between two adjacent communities. John Lyon Gardiner recorded, in 1798 , that on Long Island an Easthampton man might be known from a Southampton man "as well as a native of Kent may be distinguished from a Yorkshire man." The two towns adjoin and the two communities had been living side by side for more than a hundred and fifty years when this wide difference of speech was found still persisting. In Dorchester, Massachusetts, the land measures retained a local English trait; one finds the old Dorsetshire meas. ure of a goad in the early records. In Groton there are heard to this day " some little expressions 
and quaint uses of words" not known twenty-five miles away. In yet another Massachusetts town such unusual survivals as "dafter" for daughter Note ${ }_{4}$. have been noted in recent years. In some regions the English dialects must have been neutralized by interference; there were many colonial families in which the mother tongue varied from the father's speech. In a single Virginia parish register between 1660 and 1670 emigrants from Yorkshire, on the one hand, and from Kent and Surrey, on the other, rub shoulders with men and women from the midland of England. Now and then the word "native" against a name in the marriage register marks the young Virginian bred in this babellian confusion of English diversities. It is hard to say how his speech would be affected by the varieties of vocabulary and the contrarieties of pronunciation about him. The peculiarities known in his descendants of to-day as Americanisms, or localisms, he might readily have borrowed from both ends of England without leaving his parish, possibly without leaving his own doorstone.

$\mathrm{x}$.

American rustic lingoes show innumerable expressions detached from the ancient dialects and rearranged not by hazard, but as the result of influences too obscure to be traced. There have been

natural selection, modification by intermingling, Note 15. and changes of use produced by environment; no

Chap. III.

Register of Christ's Ch. Parish, Middlesex Co., Va.

American dialect. 
Chap. III. English dialect has bodily survived removal. But the English origin of our rustic words and accents is generally evident. For example, the twang longest associated with America by dialect writers is the distortion of certain words imperfectly represented in the spelling of heouse, teown, and keow, for house, town, and cow. Franklin long ago set down in Poor Richard's Almanac his observation that the residents of Connecticut and Cape May called a cow a keow "by a certain involuntary twist at the root of the tongue." This crescendo vowel is the recognized tag of the burlesque Yankee of the stage and comic literature. Its feline drawl may yet be caught in a state of nature in some of the mountain districts of New England, but it also exists far to the southward. There are London small shopkeepers who, along with a mock Latin "dies" for days, have an unmistakable mew in "heouse" and "teown" and "abeout." There is nothing in English dialect more evidently ancient, for it was a trait of the archaic patois of a portion of County Wexford, in Ireland, which was settled by a colony of English people who crossed St. George's Channel in the middle ages under Strongbow, full two hundred years before Chaucer's Canterbury Tales were written. These mediæval emigrants took out of England with them

Poole's

Dialect of Forth and Bargy. in A. D. I 169 and a little later such Yankee forms as "greoune" for ground, "pleough" for plow, and "teown" for town. They had other words found in American rustic dialects so widely distributed 
as not to be local, such as "kotch" for caught, Chap. III. "kiver" for cover, "man" for husband. These and other words were transplanted from England Note 16. to America four or five hundred years after the species had taken root in Ireland. Take another of the many examples of tough survival. The farmer in some parts of northern New York and elsewhere calls a fraction of a wagon load a jag. The word was colonial; in a diary of 1763 a New England parson takes pains to set down among the srnall doings of his farm that he had "gott in 2 MS. in my possession. jaggs of Rowens." This and other bits of American dialect can be explained only by going to the mother country. In Yorkshire some primitive modes of transportation still survive. The pack horse that climbs the steep moor side laden with coals for the limekilns in the mountains that overlook the Dale of the Wharfe is known as the jagging horse and the burden under which he reels is a jag. The American settlers used the jagging or pack horse on narrow forest trails throughout the colonial period. When wheels in summer and sleds in winter took the place of packing or " jagging," a small load of hay or wheat or rowen, suitable for a horse's back or to be drawn by a single horse, was still called a jag.

XI.

Negro speech in the early colonies was of as many varieties perhaps as there were tribes, and 
Снар. III. this may be one reason why there remains no considerable admixture of African words. Broken English, some grotesque examples of which are recorded, succeeded to the African tongues, and as there were large bodies of new negroes it is likely that some habitual distortions persisted in negro speech. Now and then an African word survived for a while. There was "quaqua," an instrument of music or of noise, but the word and the thing went down together. Buckra, a name for the white man on the African coast, reappeared in the West Indies and in the Carolinas. Perhaps the only old negro word surviving now is "juba," to Note 17. which no definable sense attaches. The negro "hit" was court English in Elizabeth's time; the supposed negro words “den," "dey," "dat," for them, they, that, appear in verses written in the modern dialect of Surrey. African speech has left hardly a trace even upon dialect in the United States. Slave speech caught its first accents from the bond servants and convicts who worked alongside the negro and from illiterate overseers. It probably preserved much that was worst in the English of the seventeenth century.

Social conditions.

XII.

Social conditions in America affected speech; the environment produced practical changes. The old labels applied but imperfectly to new classifications. In England a gentleman did not object 
to the title of servant, which in some cases was even an honorable distinction. But the large number of bond people sold into America to pay their passage, or as a penalty for petty crimes, seem to have gradually brought the word servant into disrepute. The bondage of a redemptioner, who might be sold from owner to owner, was degrading and his treatment was sometimes oppressive. Those who were employed not bound were at pains to be known by a distinctive term; hence the frequent recurrence of the words "hired servant." When negro slaves were added in large Note 18. numbers to the servile class, the name of servant was naturally rendered more odious by English race pride and Christian detestation of the heathen. As early as 1651 the phrase "any servant or other helpe in the family" occurs in the Massachusetts Records. "Hired man," "hand," and "hired girl " have come into use later from the same disposition to avoid the word servant. This dislike, which seems to have been half latent in the colonies, was greatly helped perhaps by that strange and widespread irruption of democratic sentiment which occurred in the later colonial and Revolutionary times. The distinction between a "Groodman" and a "Mr." or gentleman had not disappeared in the seventeenth century; it was in general use at Salem in the time of the witchcraft.

Ruggles's Hist. of Guilford, Conn., quoted in Judd's Hadley, 252. Note 19. 
Chap. III.

Proverbs and proverbial lore.

Hugh

Rode's

Boke of

Nurture,

E. E. T.S.,

lines 420 , 545,577 ,

625 .

Hist. MSS. Comm., Hatfield House, passim.

Royal Hist. MSS. Comm., Hatfield House, pt. v, p. 20I, I595.

\section{XIII.}

Along with words the early emigrant ships brought a supply of proverbs, the accepted coin of popular wisdom and almost as long-enduring as words. A writer for children in 1583 has phrases which are familiar to Americans often in a somewhat changed form. He says to his reader "looke before thou leape" and "thinke or you speake," and he says "A byrd in hand as some men say is worth ten flye at large." He says "not worth a pin" at a time when a hand-made pin was worth much more than one of those ground out now in myriads. The modern phrase "as plain as a pikestaff " appears in its older form in Hall's Satires as "pack-staff plaine," the allusion being perhaps to the rough stick which a pedestrian traveler laid over his shoulders to hang his pack upon. Lord Hunsdon writes to Cecil in 1596 that "beggars may be no chusers," and two years later he remarks that a "burnt child dreads the fire." "Down with his dust" in the modern sense is used by Fuller, the quaint church historian. When the birth of a young prince who became Louis XIV took the world by surprise twenty years after the marriage of his parents, an English letter writer alluded to the overthrow of the hopes of the displaced heir by saying, "Monsieurs cake is dough." "Thereby lies a tale" is older than Shakespeare, who gave the phrase a punning form. In a simple life with little literature sen- 
tentious proverbs abound, and the English of the CHap. III. period of settlement had many more of such allusions than have survived. An Cotton, in her account of Bacon's rebellion in Virginia, compares the soldiers besieging a camp from which Indians had already escaped to Scoggin's wife "brooding the eggs which the fox had sucked," an allusion to a "merry song" of that time. "Fair play from foule gamesters" is another of her phrases. When she says that certain events put Bacon " and those with him shrodly to their trumps believing that a few such deals or shufles... might quickly ring both cards and game out of his hands," she shows us familiar games and popular phrases in primitive forms. "Like the corn, light between the stones which might grind him to powder," reminds one of the current phrase "between the upper and the nether millstone." "Resolving with the Persians to go and worship the rising sun," is an everyday acquaintance very slightly changed more than two centuries after this clever woman wrote in the racy colonial English. (Almost all our most current proverbial philosophy has come down to us from the period when people liked to shape their thoughts into epigrams, and lacking light literature were fain to spice their speech with quaint allusions,) Proverbs abounded for other reasons in communities where utterance was trammeled and phrases with quaint outshinings were sent from man to man to carry denunciation in enigmas. "No bullets can pierce beaver 
Chap. III. skins" was short and crisp and ambiguous if reported to the authorities, but the angry Virginians expressed in these words their estimate of Berkeley's motives in not making war on the murdering Indians lest the fur trade from which he levied an enormous personal tribute should be interrupted. Believing at last that their oppressions were made heavier in order to incite them to rebellion, another proverb with a more sinister meaning went like a courier of discontent up and down the river settlements. "Rebel's forfeitures will be loyal inheritances" was the prophetic phrase repeated from one indignant planter to his next neighbor. Such proverbs do not become folk-lore, they express political passion smothered but ready to burst into flame. There is another sort of readymade traditional speech that is neither proverb nor politics. Friday was of old a marked day among the credulous rulgar as it is now, but the ancient notion had to do with weather. They called it either king or worling (worlding) "bicause it is

Harrison in Holinshed, i, $37^{8}$.

Harl. Miscell., viii, $33^{8}$. either the fairest or foulest of the seauen." "Oisters," says Harrison, in 1577 , "are generallie foreborne in the foure hot moneths of the yeare, .. . which are void of the letter R." This rule for oysters must have been much older and prevalent beyond England. The Dutch over their tankards had a humorous variant of it, to the effect that water was to be taken only in months without an $r$. The familiar mnemonic jingle that begins with "thirty days hath September," in its older form 
" hath November," was recited in the days of Elizabeth; its pedigree runs far back to an ancient Latin calendar verse about ideas and nones. CHAP. III. Trivial as these instances seem, they enable us to imagine the motley assortment of antique mental furniture with which the emigrants were outfitted for homely thinking and everyday talking in a new hemisphere.

\section{XIV.}

Cotton Mather accounts the visitation of witches in 1692 a retribution for the little sorceries of the superstiyoung people who "would often cure hurts and tions. spells and practice detestable conjurations with sieves and keys and peas and nails and horseshoes to learn things for which they had a forbidden and impious curiosity." Such minor "conjurations" are still known in by-places, and this mode of pretending to satisfy "an impious curiosity" must have been very ancient. That a knife, fork, or a pair of scissors which sticks in the floor is lucky was an article of folk-faith in the good old colony time, and for how long before no one knows. Journal of Sarah Eve. Certain texts of Scripture were in use for divination in colonial New Jersey, perhaps by the same kind of charm that has been used down to our own time, to tell whom the rustic swain or the curious Harrison, i, 409, 410 . pean tradition that the horned cattle uttered audible prayers at midnight on each return of the anniversary of Christ's birth in a stable was still handed

\section{Barber's} New Jersey Collection, r49. 
СнAP. III. down to children in the up-country and elsewhere in the first half of the nineteenth century. The American back-country man, finding his horse's mane almost hopelessly tangled in the morning, remarks as he tries to extricate it that the "witches" have done it. This faded relic of a picturesque superstition that came down through a long line of English ancestors from the middle ages Shakespeare touched into poetry:

Romeo and

Juliet, i, 4 .

Comp.

Douce, Illustrations of Shaks., ii, 180 .
Folkliterature.
... The very Mab

That plats the manes of horses in the night, And bakes the elf-locks into foul sluttish hairs, Which once untangled much misfortune bodes.

The same ancient belief in small deviltries is embalmed in the name "feather-bed witches" yet applied to the knotted feathers in a bed. Countless other bits of folk-wisdom were transported to American shores as part of the intellectual kit of uncritical people. To call such surviving mediæval and ancient beliefs quite useless would be rash; they at least supplied material to the imagination and rudely served as substitutes for literature.

\section{XV.}

The higher forms of folk-lore may be called folk-literature. The rustic classic of other days was carried in the memory as folk-tale and ballad and transmitted orally from generation to generation. Legends of place and fairy myths, the achievement of giant-killing Jack, and the roman- 
tic tale of lucky Cinderella, now relegated to the Chap. III. nursery, delighted men and women for thousands of years. For ages in one form and another innocent simplicity, wearing a red riding hood, and crafty ferocity in the form of a wolf, afforded a needed excitement in the long wintry evenings. Ballads of love and bloody ballads of slaughter were sung while the flicker of failing firelight on the wide hearth peopled the remote corners of the room with grotesque shadows in motion. Chevy Chase and other ballads, the heritage of the English generations, were chanted to young people, keeping alive British tradition and feeling in the American woods. The merry mirth-provoking old English songs of primitive humor reappear in Virginia. One of these, the Song of Scoggin, is preserved to us by title only in a proscription of it by the eminent and godly Mr. Perkins. As the ideas and feelings embodied in the old unwritten ballads brought over the sea grew dim and remote, these same ballads absorbed by degrees, and with no more change than was necessary, a flavor of America. The highly interesting Scottish-English ballad of Young Beichan, or Lord Bateman, for example, the versions of which in Great Britain are many, became American when repeated by generations who had forgotten the crusades. Susan Pye, the Saracen girl, became Suky Fry, an American, who, having cared for an English nobleman in prison, goes to England to have the same incredible adventure that befalls the heroine of the older $\begin{aligned} & \text { Child's } \\ & \text { Version } L \text {, }\end{aligned}$ 
Chap. III. and see note $a$.

Note 20.

Literature in the colonies.

ballad, and she wears the same jewels and is described in almost the same lines. Other ballads and songs, manifestly of English origin, were current with slight changes in the older States until recent times. But American events sometimes gave birth to American rhymes: Bacon's rebellion was versified in Virginia, and Lovewell's gallant but disastrous fight in Maine gave rise to a gory ballad that put Chevy Chase out of countenance, and became "the most beloved of all" in New England. Very curious and perhaps very antique forms of English folk-tales were brought to America. For example, there was in New England a version of the world-old tale of Cinderella known as Rose, Pink, and Piney (or Peony), a version apparently unknown to collectors of English folklore, and yet other traditional tales were long preserved in ancient forms that have been lost in the mother country.

\section{XVI.}

Some collections of books were brought to the colonies at the outset that might be called large libraries in a time when entire libraries of average size were often kept in a single chest. Elder Brewster, of Plymouth, who had been a printer in Holland, left some hundreds of books. John Eliot, Stiles MS., the Indian apostle, if one may trust family tradiItinerary, Yale College. tion, brought twenty-three barrels of literature with him. "Worshipful Mr. Winthrop," of Connecticut, had the most princely library of the time 
in the colonies, though it contained but about a thousand volumes. He prized alchemical, astrological, and other esoteric trumpery; some of his books of this character that yet remain are bound in sheets of ancient black-letter with illuminated initials and in bits of manuscript missals in color. Antiques were thus sacrificed as superstitious, perhaps, and used to wrap up favorite essays on the philosopher's stone and potable gold, superstitions dear to the heart of the learned fellow of the Royal Society. Winthrop had also many unpractical works on practical themesbooks on agriculture and medicine by followers of Pliny and Paracelsus. John Harvard had a library which was a part of his gift to Harvard College. There were a considerable number of books in the colonies, but in the first period there was very little literature in the strict sense of the word. Theology dominated in every collection. If George Sandys, the traveler and poet, consoled his lonely hours in Virginia with a few books of English literature we have no record of it, but he brought with him a copy of "the sweet-tong'd Ovid," which he rendered into English verse in Jamestown "by that imperfect light which was snatcht from the hours of night and repose," while the unhappy colony of which he was an officer was agitated by the alarms of Indian war and pestilence. Most of the books read in the colonies were far removed from the "never-discontinued rhymes" of Ovid. There is ever a literature below literature

Chap. III.

The remains of Winthrop's library in N. Y. Society Library. 
CHAP. III. that has to do with the hopes and fears, the beliefs and aspirations of uncritical people. In 1619 many little sub-colonies were fitting out for Virginia. With one of these there were sent by the shareholders, along with arms and armor, axes and beetle rings and provisions, certain necessary books.

Smith of Nibley MSS., N. Y. Pub. Library.

Note 2 r.

Note 22. The original list is preserved. There were two church Bibles and two books of common prayer. The literary outfit was completed by " 2 books of the practice of piety, 3 books of the playne man's pathway," and "halfe a reme of paper." Bishop Bayly's "Practice of Piety directing a Christian how to walke that he may please God" is at once half mediæval and wholly Puritan in tone. Its popularity and its almost divine authority with the men of that age is a remarkable literary phenomenon. It turns up in almost every Virginia probate inventory, and is found far into the eighteenth century, often associated with its running mate, Dent's “Plaine Man's Pathway to Heaven wherein every man may clearly see whether he shall be saved or damned." At the urgent request of the eminent Robert Boyle, the Practice of Piety was translated into the Indian tongue of Massachusetts. In a Virginia library of five volumes, in 1648, the inevitable Practice of Piety has for companions "Mr. Calvin's Institutions"- that is, Calvin's Institutes-" the true watch," "Christ's combat with Satan," and "effectual Calling." A Virginia clergyman three years earlier left "thirty great books in folio, most of them old authors," 
and "about fifty books in quarto, most of them being lattin books." We have here two typical libraries-the cumbrous folios and the handy square small quartos, mostly Latin, of the scholar, on the one hand, and the half dozen more or less guide books to piety, sound doctrine, and paradise which gave a sense of security to a reputable family. It was not until the latter half of the century that one finds among the richer planters those encyclopedic books on various subjects that gave their owners an air of general information, and it is only in the last quarter of the century that we can trace in the houses of a few educated Virginians such masterpieces of real literature as Ralegh's History of the World and Bacon's Advancement of Learning. There were also the Essays of Montaigne, who figures in the inventories as "Michael, Lord Montague," and the Religio Medici. In an inventory of 1699 a copy of Macbeth turns up opportunely to give notice that the slowly widening fame of Shakespeare had reached the New World before the century closed.

XVII.

Nothing that can properly be called American literature was produced in the colonies in the early American literature. seventeenth century-nothing worthy of the name in its later time. Narratives of American travel were written by Captain John Smith and others. George Sandys, an English poet, translated Ovid while sojourning in Virginia; and Anne Bradstreet; 
Cнар. III. whose birth and education were wholly English, wrote in Massachusetts some clever verses in imiNote 24. tation of Sylvester's translation of Du Bartas"divine Du Bartas," as he was called, translated by "silver-tongued Sylvester," admiration for whom was the literary vogue in England in the seventeenth century. But all such productions in the first generation belong to English letters; they have no relation of any kind to American literature ; and all have gone into an oblivion as profound as that which has enveloped the admired Du Bartas himself. Vigorous works of polemical theology were produced by the great lights of English Puritanism exiled to New England, but they were addressed to an English audience, and were mostly printed in the mother country, where they were part of the current debates on church government and theology. Notwithstanding the ability of their authors, these books have no permanent value except as documents of historical reference.

The Day of Doom, and other poems.

\section{XVIII.}

Nor can much be said for the writings of the period following, when the valetudinarian Wigglesworth produced his Day of Doom, in which the Christ is alternately a country judge and a fierce Moloch, and where the pious reader confronts such scenes as the damnation of non-elect infants for the guilt of Adam's sin, though they are assigned to "the easiest room in hell." The poem 
is done in the characteristic doggerel of the Bay Chap. III. Psalm Book, without taste or humor. Its hideous descriptions, irresistibly comic to a modern reader, were suited to the temper of the time; they seemed realistic forecasts of the almost imminent final catastrophe, and edition after edition was sold. Only ten years before the outbreak of the American Revolution a Boston paper could speak of Michael Wigglesworth's "divine poems." Versification was an unreproved amusement in all the colonies, but most of the wooden rhymes of the time rested in manuscript. In New England the habitual use of the printing press gave opportunity for prolific facility to win something like distinction. Benjamin Tompson was a later and less lugubrious writer than Wigglesworth, and he achieved fame enough to have it graven on his tombstone that he was the "renowned poet of New England." The histories of the Indian wars of New England, the political tractates, and the accounts of Bacon's rebellion in Virginia and the poems about it, the indigestible tales with which Increase Mather filled his books on illustrious providences and ominous comets, the Quaker and anti-Quaker diatribes of gall and wormwood, as indeed all the writings in all the colonies during the seventeenth century, are almost without exception utterly non-luminous. Their lack of any inspiration is witness to the truth that notwithstanding intellectual activity artistic creation is impossible in an unsympathetic environment. Life was too material,

Dr. S. A. Green in Mass. Hist. Soc. Proc., June, I895. 
CHAP. III. human energy and thought were spent in the battle with circumstances and the more bootless struggle of petty religious and theological debate. There were no detached minds, there could be no production of true literature. The odds would have been against Shakespeare himself.

The antinaturalistic sentiment of the time.

Compare Hakewill's Declaration of the Providence of God, 1627, passim, et al.

Howell's Letters.

\section{XIX.}

The age was partly responsible. If there had been any love of Nature in the seventeenth century, American settlers would have shown some appreciation of its aspects in a new world. But the prevailing sentiment of the time was that Nature had long been steadily deteriorating, and that the everlasting frame of the universe was in a state of rack and decay. For the sublime in external Nature there was no taste. An accomplished English traveler in 162I describes the "hideous" Alps, which he had crossed, as "uncouth, huge, monstrous excrescences of Nature." This, we may suppose, represents the sentiment of English settlers toward the grand primeval wilderness about them. "Uncouth" is Captain John Smith's only epithet for the picturesque wilderness trails through which he marched; and George Sandys, though a poet, never seems to look upon the wilderness except as an obstruction and an enemy. The colonial verse writer does not suffer any intrusion into his meditations of the over-awing effects of Natare, primitive and unsubdued, as he encountered it. What 
contemplation there is in the books and letters of the time expends itself on the supernatural or revels in the merely grewsome.

\section{$\mathrm{xx}$.}

This "uncouth, huge, monstrous" wilderness puts its thumb mark on the character of the people otherwise than by contemplation. They grew up in the earlier generations woodsmen. $<$ Distinctively English characteristics fell away from them.) The exigencies of a new country made them quickwitted and shifty. The dignity and repose of bearing that belong to a fixed position in an older civilization were lost, for the time at least. The American was pushing, aggressive, inquisitive. $\mathrm{He}$ was also more open-minded than his ancestors; $\{\mathrm{a}$ change of circumstances broke up the conservative crust of centuries of English life.> The "go" of a new country came into the new life and a hundred years after the early settlement of the colonies an English clergyman in Virginia sketches the American as we have known him-nimble-witted, but less patient and profound than the Englishman.

Men of the woods.

Hugh Jones, Present State of Virginia, pt. ii, chap. v.

XXI.

The survivors of seventeenth century libraries The old books. let us know what the old books were like. They varied greatly in size. There was the princely tome in folio, sometimes at least stoutly corded 
Chap. III. and honestly bound in good leather, now and then it was gilded and richly tooled. Then there were small quartos thick and small quartos thin, some bound and tooled, but many stitched and homebound by the owner in parchment sewed through and through by strings of sheepskin or clad in scraps of old missals or merely covered with leaves of old books. Below this the sizes and shapes are too various and often too nondescript to be set down, running all the way to twenty-fourmos or something of the sort. Regularity in size or shape was not important in libraries that usually were not shelved but stored in chests. If there were Latin works, there would be many in parchment cover, or if from the Rhine country some would be elaborately stamped in pigskin and held together by ockumy clasps. A few manuscripts one would be pretty sure to find-a diary or a journal of travel, or a controversial tract, or some poems innocent of print. From college the owner brought in his own handwriting a carefully copied digest of logic, metaphysics, divinity, with arithmetic, or geometry. He may have added some rules and diagrams for land surveying. Many of the manuscripts were transcripts of printed books not easily come by in those days. Some professional men of the time saved money and learned their texts by transcribing from books borrowed from others; and lawyers bound later laws in manuscript in the same volume with printed statutes. Works on alchemy, with some on the art of war, have come 
to us in transcripts. The elegance of the old CHAP. III. decorative "secretary's hand," learned by patient application under a writing master or his usher, shames the slovenliness of modern scribbling, and sometimes excels in beauty the fine old typography which carried over the traditional taste and painstaking of the mediæval copyist into a rare mechanical art.

\section{ElUCIDATIONS.}

James Laing, a Scottish writer of the Reformation period, expresses this contempt for vulgar tongues as proper only to barbarians and heretics: "Tres sunt linguæ elegantes et ingenuæ, Hebraica, Greca, et Latina quæ nobilibus principibus sunt dignæ:-Ceteras linguas cum sint barbaræ barbaris et hæreticis tanquam propriis relinqux." Quoted in McCrie's Life of Knox, 472.

Puttenham's Arte of English Poesie, published in 1589, is a principal authority, but the condition of the language may be mainly deduced from the literature of the period. One of the sources of corruption noticed and lamented is "the peevish affectation of words out of primative languages" by "schollers." Many "inkhorne termes" were brought in by preachers and schoolmasters. The words " penetrate," "penetrable," and "indignitie" are examples of these fresh intruders. Arber's Puttenham, I56-159. In Alexander Gill's grammar of 1619 , quoted in Masson's Milton, i, 55, is a denunciation of the intrusion of words of Latin origin, such as " common, vices, envy, malice" and "virtue, study, justice, pity, mercy, compassion, profit, commodity, color, grave, favor, acceptance." " But whither pray," demands Gill, "in all the world have you banished those words which our forefathers used for these new fangled ones? Are our words to be exiled like our citizens?" The enriching of the language with Latin and French terms was inevitable; the three languages had been in juxtaposition in England for centuries, and they were sometimes jumbled together unconsciously. In Brayley and Britton's History of Hertfordshire is an example of a three-ply interweaving of the languages in an old Description of the Manor and

Note I, page 96.

Note 2, page 97. 
Chap. III. Manor House of Rye: “ Item granarum, 16 equi et vaccæ, cum le storehous mercandizarum 2000 marcae, Item le byldyng de le inner court edificat cum bryke," etc. Many such triple macaroni passages could be accumulated.

Note 3, page 97.

Note 4, page 98 .

Note 5, page 102.

Note 6, page 102.
"And certaynly our langage now vsed varyeth ferre from that whiche was vsed and spoken whan I was borne. For we englysshe men ben borne vnder the domynacon of the mone which is neuer stedfaste. . . . And that comyn englysshe that is spoken in one shyre varyeth from a nother." Caxton's Prologue to the Eneydos, A. D. 1490. The changes in speech in the sixteenth and early seventeenth centuries were nearly as rapid as in the time of Caxton. Take this intimation from Evelyn's Diary in the year 1654: "Here [at Beverly] a very old woman shew'd us the monuments, and being above one hundred years old spake the language of Queen Marie's daies, in whose time she was born."

"Victories, plantations, frontieres, staples of commerce," etc., are enumerated by John Evelyn as "reasons both of additions and corruptions, of the English Language." All changes of usage were accounted corruptions, and stay-at-home men have grieved for three centuries over the "corruptions " introduced into the tongue from the various offshoots of the mother country.

The word "turkish" had perhaps come to signify "foreign" or "outlandish" in European tongues. It is to be noted that a third German name for the turkey was wälsches $h u h n$, the foreign fowl. This may indeed be sufficient reason for "turkish corn" in several languages, as wälsch-korn or foreign corn is one of the designations of maize in German.

John Clayton, the parson, says in a letter to the Royal Society in the seventeenth century about Virginia: "There's a great sort of ravenous Bird that feeds apon Carrion as big very nigh as an Eagle, which they call a Turkey Bustard, . . . whence its name; it is nothing of the same sort of Bird as our Turkey Bustard." Johnson's Dictionary of 1755 defines "bustard" by " a wild turkey." We may not conclude from Clayton's term that the great vulture was called a turkey bustard before he became a buzzard, for a dozen years earlier in these Transactions, xi, 63I, Glover writes "Turkie Buzzard," and very much earlier yet, in 1614, Hamor has "Turkie Bussards." The author of the True Declaration of Virginia, I6Io, does not know either name; he calls the birds "cormerants." One might suspect that the name is a corruption of "bastard turkey" (compare "bastard plover" in the 
regulations of Henry VIII's household, Forsyth's Antiquary's Chap. III. Portfolio, i, 187), or that it has some relation to the French dindon batard, but there is no evidence in favor of such a conjecture. The vulture was often mistaken for the turkey. Castiglioni Viaggio negli Stati Uniti, i, 225. We have indeed a tangle of the names of two large European birds, the buzzard and the bustard, with the American turkey and turkey buzzard. It is with pleasure that I pass the puzzle to philologists. Apropos of the possible confusion one way or the other between dindon bastard and turkey bustard or buzzard, there is in Le Page du Pratz, Histoire de la Louisiane, 1738, ii, 418, a curious distortion of another English name of this same vulture, which he calls "Carencro" [that is, carrion crow], " qui est aussi noir qu'un Merle \& aussi gros qu'un Dindon."

The suggestion of Acosta is that since the Italians call maize grano turco, Pliny's description of millet may have been intended Note 7, for maize, and that the plant may have been known to the ancients. It was as hard to believe in that day that there was anything of value unknown to Pliny as that there could be any truth of philosophy not deducible from Aristotle. The confusion between buckwheat, or "saracen wheat" as it was called, and the newer maize, though not heretofore suspected, is almost beyond doubt. Lescarbot, in La Conversion des Savvages, 16 Io, gives a list of plants cultivated by the Iroquois. In it there appears "du ble mahis (ou Sarazin)." In the Burrows reprint of the Jesuit Relations, i, 85, this passage is Englished by " maize wheat (or Buckwheat)." If this rendering were correct, it would still show the confusion of the two, but Lescarbot did not suppose any grain but maize to exist among the Indians. "Sarazin" is here but another name for maize, in explanation of the less familiar "blé mahis," or more properly "mays." The name in French or Italian was conferred, no doubt, when it was yet not well distinguished from buckwheat, and it was probably used at first interchangeably with ble de turquie, the notion of origin conveyed being identical in the two names. "Grano saraceno" appears to be still applied in Italian to both maize and buckwheat. Baretti's Italian-English Dictionary, edition of 1854 , has no other definition of "grano saraceno" than maize, while it defines maize by "fromentone, grano saraceno, grano turco." Yet Castiglioni adheres to "frumento saraceno" or "grano saraceno" for buckwheat, and "grano turco" for maize. Viaggio negli Stati Uniti (1785, 1787), i, $36 ;$ ii, 7 , and passim.

page 102. 
CHAP. III.

Note 8 , page 103.

Note 9, page I03.

Note 10, page 105.
Strachey, in his account of Virginia in the "yearely daies " of the colony, to imitate his expression, says of the beans of the Indians, "Their beanes . . . are the same which the Turks call garvances," an identification as wide of the mark as most of those on which names of American plants are founded. In $1633 \mathrm{De}$ Vries, the Dutch explorer, was making his way up the Delaware to secure some of the "Boonen van de Wilde," or Indian beans, and these on the next page he calls "Turchse Boonen "- that is, Turkish beans. Korte Historael, etc., IOI, 102. In the English version of Acrelius "Turkish beans" and "large beans " appear as two of the garden vegetables cultivated in New Sweden. The original Swedish at p. 167 has “Turskska Bönor" and "störa Bonor," which in our common speech would be Turkish beans and pole beans, indicating that the so-called Turkish beans were not grown on poles, but, as we know, twined themselves about the growing corn stalks. In the papers reviewing and, it might be said, enriching De Candolle's Origin of Cultivated Plants, the learned authors, Gray and Trumbull, have missed the passage above in De Vries, which would have shown the error in Van der Donck that they suspect. See American Journal of Science for August, 1883, p. 134. Van der Donck is so far misled by the name "Turkish" as to suppose the Indian bean to have been introduced by the Dutch. The name gallivance is applied to some plant in Pennsylvania soon after Penn's settlement, and in a Complete Discovery of the state of Carolina, 1682 , the name appears as "Callavance," from which we need not infer the presence of the garabanzo as cultivated in Spain, Mexico, etc., but merely a confusion of very different plants by people who had not seen both.

The New England "rye and Indian" was known in the eighteenth century, and perhaps earlier; it figures strangely in Castiglioni's Italian as "grano turco misto con segale formano delle crescenze senza lievito." The phrases "English grain" and "English grass" appear to have survived in New England until the American Revolution abolished all things English, in name at least. In a manuscript diary of Rev. Justus Forward, of Belchertown, Mass, in my possession, it is set down, under date of June 15, 1763, that "grass and English grain look extraordinary well"; and on the preceding May I Ith the diarist notes that there is "considerable feed in English pasture."

The use of husk for the bran or covering of the grain was in accordance with English usage at the time. A Virginia writer, 
in the Transactions of the Royal Society for 1666 , uses the verb CHAP. III. " un-husk" in speaking of rice and barley. Clayton, the clergyman, in writing of Virginia in the Philosophical Transactions, speaks of husks of the kermes or little galls on oak trees. The application of the word to the bran of the corn, the skin or husk of the grain, was thus very natural. In some doggerel by Davy Crockett when a boy these lines occur :

She sifted the meal, she give me the huss;

She baked the bread, she give me the crus.

This use of husk I found still extant in Charleston, S. C., in I 884. " Nubbin," used in English provincial dialects for the stump of a tree, came into general use in America for a dwarfed ear of corn, and I suspect that some analogous use of the word existed in colloquial English at the time. Roasting ears, an early name for green corn in the Chesapeake and middle colonies, is yet applied to green corn however cooked, and whether cooked or not, over a large part of the United States. Compare Beverley's Virginia, book iii, I 5, and Rush's letter in Castiglioni, Viaggio negli Stati Uniti, ii, 44. Acosta speaks of a large round variety of corn that the Spaniards ate roasted " as a delicious food, more savory than roast beans or peas." Livre iv, chap. xvi.

The aroughcun of John Smith goes through innumerable forms. There is raconne very early in Morton's New English Canaan, p. 79, and in the perfect Description of Virginia of $1649 ;$ ratoons in Wilson's Account of Carolina, I682; and roacoans in the State of England, I683, p. 63. Barrett's maps, of about I775, have three forms-“ Aroughena, a sort of badger," and "roscones," in the same Virginia list ; in the New England list the animal is "rackoon."

It is pohickory in some early writings, as in Baltimore's " $\mathrm{Re}$. lation " of 1634 , where it is said to be a "wild sweet wall-nut." The hickory nut is still called a walnut in parts of New England and New York ; it is the white walnut in contradistinction to the black. But Gronovius's Flora Virginica, I 50, calls the butternut white walnut thus: "Juglans alba . . Anglice white walnut, Clayton "- that is, on the authority of Clayton, the Virginia botanist. It is still usually so called in communities of Virginia derivation.

Barbecue is generally accounted a West Indian word, but it was in general use in the colonies, and may have been known to

Note II, page 106.

Note 12, page 107.

Note $\mathbf{1 3}_{3}$ page 107. 
CHAP. III. some of the Indians of the mainland. Beverley, in his history of Virginia, 1705, says that the Virginia Indians have a second way of "broyling . . . by laying it upon Sticks raised upon Forks at some distance above the live Coals, which heats more gently . . . this they, and we also from them, call Barbacueing." The word is elsewhere among the colonists " barbecute," and is applied to the roasting of venison wrapped in leaves in thie ashes. Compare also Bossu's Nouveaux Voyages, I777, where barbecue is traced to an Indian word, barboka, which signified the wickerwork"les claies"- on which the meat was laid. Page 178 and footnote.

Note 14 , page rog.

Note 15 , page Iog.

Note 16 , page III.

Note 17 , page II2.

Compare this word dafter, for daughter, with the old pronunciation "oft," for ought. In the Order of Orthography, by Joseph Prat, London, 1622, the word ought is thus given "oft." Prat lays it down as a rule that where " $\mathrm{s}$ " precedes the terminal " tion," the sound shun must not be given, by which rule the accepted form of such words in good speech would be, for example, combus-ti-on. Honor and honour, favor and favour, are "indifferently written," says Prat. The word mile is unchanged in the plural, as " one mile, twenty mile." As an example of the " barbarous speech of the common people," he has "yerbs" for herbs, "dater" for daughter, "twonty" for twenty, "feale" and "finegar" for "veale and vineger."

This mixing of variant forms of rustic English was kept up by fresh arrivals from England, and in the eighteenth century it was complicated by the great exodus of people to some of the colonies from the north of Ireland. Manifest traces of this ScotchIrish admixture may be found in Pennsylvania, in the Ohio Valley and westward, and along another line of emigration in the Appalachian valleys and the table-lands of Virginia and the Carolinas.

"Gom," in this dialect of the Forth and Bargy, means a simpleton; in other local English it is, as in America, "gump." "Goss" in various dialects means gorse or furze. As gorse is not known in the United States the word has no popular meaning, but it has survived in the single dialect phrase often heard in certain places, "Give him goss!" - that is, a chastisement as with gorse or furze.

The following nonsensical verse was remembered by my father as sung by the Virginia slaves in his boyhood-that is to say, in the first quarter of the nineteenth century : 
Juba dis an' juba dat,

An' juba roun' de kittle o' fat ;

Juba heah, an' juba dah,

An' juba, juba ebry whah.

In the coast region of South Carolina, where the negroes are much the larger part of the population, and where "new negroes" were run in from Africa at a late period, the corrupt speech is called the Gullah dialect, from the Gullah or Angola negroes. The vocabulary has few words that are not evidently English in origin, The effect is somewhat that of English badly spoken by a foreigner, who ignores the natural quantity of the vowels. There is a French nasal in the sound of final $n-$ fine, for example, takes the sound of the French fin.

In Smyth's Tour, i, 235, he remarks on the unwillingness to be called a servant by the frontiersman of the late colonial period. The use of the word servant was evidently narrower in the colonies than in England, though Mr. Albert Matthews has furnished me with several references to " hired servant" and " hired servant man " in the first half of the eighteenth century. As some of these were in advertisements of runaways, the hired servant must have been bound by contract for a year, according to the custom at $t$ lat time. Even in such advertisements for runaways in New Jersey, Mr. Matthews notes the term “an Irish hired man," and te has furnished me with a number of instances of the modern use of the word " help" in England for a person employed in a capacity a little above that of a domestic servant. Under date of Philadelphia, December 6, 1748, Kalm says that a distinction was made by the English inhabitants of Pennsylvania between a servant and a "serving or bond servant" for a term of years. As the phrase does not occur in any advertisement of runaways or elsewhere, so far as I know, its use must have been local. Servant was applied to a slave, and thus the depth of infamy was reached.

In Halliwell's English Dialects, 28, there is a Lovers' Dialogue, a Wiltshire piece. " Hold not so breach now," says the maiden to her wooer. The word is in the exact sense of the popular American word "brash," and sheds some light on its derivation, regarding which both the Oxford Dictionary and the Century Dictionary grope a little for want of this instance. In a fifteenth century Essex poem in Halliwell-

Be thou never to smert

To her mennys consayle-

is an older form of an Americanism - " too smart to take advice."

Note 18 , page ir3.

Note 19, page Ir 3 . 
Chap. III. Chief-Justice Morris, of New York, in 1737 said in the Zenger trial, "An ingenious man has smartly enough observed," etc. In the couplet-

Tharefore y wylle me holly halde

To that language that Englisch ys calde-

quoted in Halliwell's Dialects, p. 7, from a MS., the word " holly," for wholly, suggests the "New England umlaut," as it has been called. In Hearne's works there is an extract from a version of Pierce the Ploughman's Crede which closes with the words-

And in the heighe holy gost holly I beleue,

where the difference between the words " holy" and "wholly" appears to be that which one often hears in New England, even among educated people. I have pointed out in a previous note, on the authority of Franklin, the early existence in parts of Pennsylvania of what are now deemed New England peculiarities. John Bartram, the Pennsylvania botanist, probably used the umlaut pronunciation like a Vermonter. In his Observations he writes, "We rod over middling land," p. 66. " To get shut of," for to get rid of, appears in various English and American dialects. "Bail" for the handle of a pail or kettle is still used in dialect in England. It appears in a will of 1463 , where the English editor finds it needful to explain it. Compare Bury Wills, 23, 242. It is in general use in the southern and western parts of the United States, and accounted a preferable word. "My woman " appears more than once in Braithwayt's Drunken Barnaby, 124, 171, as a respectful equivalent for my wife, with " uxor" on the opposite page as the Latin. This is precisely the usage of the rustic people in New England; farther south the farmer says "my old woman," though his wife be never so young. "Party" for person, which modern purists account recent and reprehensible slang, was in abundant use in older times. Increase Mather has the " sick party recovered," Providences, 192, and one even hears of dear parties. The Camden Miscellany, vol. iii, quotes from MS. :

The partie nowe is gone and closelie clade in clay.

In northern regions of the United States a sick person is said by the country people to be "handled" by his disease. In Howard's Collection of Letters, 273, the Duke of Norfolk writes to Henry VIII, "I have ben so sore handeled with myne old Disease," and there are other examples. "Fall " for autumn is now mainly American, but there are English precedents enough for it, and it would be a pity to lose from literary use so good a word. 
There are instances of its early use in the colonies sometimes in Chap. III. the full form, as " this last fall of the leafe." Virginia Calendar, I688. (But what is "the fall of the leafe" directed to be taken out in drawing a fowl in the Compleat Cook of 1658 ?) Parson Clayton, writing of Virginia, says, "When they go a Shooting or Hunting, as they call it," etc. He marks here an early difference of usage that has persisted. It has been asserted that " rooster" is a word produced by American mock modesty. But " roost-fowl," at least, was a form that appeared as early as I 701 , Sewall's Diary, vi, 33, and I have seen " roost-cock" in English use earlier than the beginning of colony planting. "Toat railes" appears in the Remonstrance of Gloucester County, Virginia, as early as 1677. State Paper Office, Virginia Papers, 62. Tote must have been of English origin. It appears in a Boston paper before the Revolution, and is found in the old "tote roads" of Maine. But there are words of distinctly colonial origin. "Gum " for beehive in some local dialects, came from the use of a section of a hollow gum tree for hiving bees and other purposes. Com1 rare "a large cask or gum " in Virginia Gazette, June 21, I744, and the Western pioneer's proverbial boast that he was cradled in a "bee-gum." The number of illustrative instances that might be given from my own notes alone would require a volume. See two papers in Century Magazine, April and October, 1894.

For Sukey Fry and other ballads I am indebted to my daughter, Mrs. Elizabeth Eggleston Seelye. They were taken from the lips of an old lady of New England birth and lineage who may have been the last person treasuring these bits of colonial folklore. She could remember only a few verses of Sukey Fry, supplying the rest by narrative. "A young nobleman coming to America met a young girl, Sukey Fry, and they fell in love. He was put into prison, and she visited him and carried him things to eat. He agreed, when released, to wait for her seven years unmarried. He returned to England:

"Seven years passed away,

And seven years more followed on.

$\mathrm{He}$ at length married some one else. The scene is at the wedding. The servant at the door says :

" ' At your gate, sir, stands the fairest creature

That ever my two eyes did see ;

On every finger she has a diamond,

And on her breast plates one, two, three.

Note 20, page 120. 
Chap. III.

The golden ringlets on her shoulders,

Are worth more than you and your bride too.'

"Lord Bateman smote his hand upon the table, And split the leaf in pieces three,

' I'll stake my life and all my living

That Sukey Fry has crossed the sea !'

The father of the bride says :

" 'Oh, cursed be that Sukey Fry,

I wish she had on the ocean died!'

Lord Bateman replies :

“ 'I married your daughter to-day 'tis true,

I'm sure she's none the worse for me;

She rode here on my horse and saddle,

She may go home in her coaches free.' "

See the many versions of the ballad in Child's Scottish and English Ballads, and especially Child's learned treatment of its variations in the quarto edition, part ii, 454-483. One can not but regret that Professor Child did not have the pleasure of knowing that the "Isbel," "Dame Essels," "Susy Pye," and "Sophia," of other versions had emigrated with the colonists and assumed the name of Sukey Fry. Many comparisons with the Scottish and the English versions suggest themselves, but they must be left for folk-lorists. But is it on account of the name "Susy Pye" in the ballad, or perhaps on account of the sense of colored or painted in the word " pie," or " pye " that this seems to have been a name for a Moor? In the Records of Massachusetts Colony, I638, p. 239, "George Pye, a Moor," appears. Rose, Pink, and Piney is among the tales collected by Mrs. Seelye. Piney is the most frequent pronunciation of peony in rustic speech. There is an allied story in the little collection referred to called Pussy Catskin. It is substantially the same story as that given in Catskin's Garland in Child's Ballads, but the American version is in prose and much more antique than the ballad as Child gives it. The word trencher is preserved in it, though the meaning of the word must have been very obscure to those who recited it last. The tale is known in many tongues. See Child's English and Scottish Ballads, viii, I 72 ff. See also Marian Roalfe Cox's Cinclerella.

Note 21 , page r22.

In I697 All Faith's Parish received a library from " the Honorable Kenellem Chiseldene." It was composed as follows: "foure Bibles, one booke called the whole duty of man, three bookes in defence of the Common prayer, three Catekisme, and one lecton 
booke"-that is, a "lecture" book as it is elsewhere called, perhaps a book of homilies. Vestry Book of All Faith's, Manuscript in Maryland Historical Society. We have here, and in the instance cited in the text, traces of the ancient custom of keeping certain books in the churches, sometimes chained. Compare Marsden's early Puritans, 236. See the seventeen books provided for the use of the first clergyman in New Netherlands, O'Callaghan's History of New Netherlands, i, 454.

After much seeking I found a copy of the Practice of Piety where it was least to be expected, in the Graham Library at the Century Club, New York. It owes its preservation from the destruction that has befallen a myriad other copies to the chance that Samuel Butler once owned it and wrote some lines in it.

Prof. C. E. Norton, in his Life of Anne Bradstreet prefixed to a modern edition of her poems, says, "There is, I believe, no evidence that there was a copy of Shakespeare's plays in Massachusetts during the seventeenth century." Apropos of a line of Mrs. Bradstreet's which resembles the line in Hamlet, v, ii, 337, 388 , this remark is made. But, as Mrs. Bradstreet was an inmate of the family of the Earl of Lincoln in her youth, and a late and reluctant adherent to New England Puritanism, she may have seen Hamlet on the stage in England. Shakespeare was never mentioned or quoted by any American writer in the seventeenth century, so far as I know. Even in England his fame was of slow growth. Peacham's Compleat Gentleman, 1660, calls George Buchanan, whose fame rests on his Latin poems, "the prince of poets of our time," and he does not think Shakespeare worth naming at all. The bare word " Macbeth" in the Virginia inventory of Captain Arthur Spicer, 1699, is the first allusion to his work from an American source that I know. Another Virginian, Edmund Berkeley, who died in 1718 , had Shakespeare's works. William and Mary Quarterly, ii, 134, 250, and passim.

Nathaniel Ward, a contemporary, says of Anne Bradstreet that she is "a right Du Bartas girle." A single verse of hers will serve to illustrate her method and her admiration for her model :

But when my wondering eyes and curious heart

Great Bartas sugared lines do but read o'er,

Fool do I grudge the muses did not part

Twix him and me the overfluent store.

The reader who cares to see what the so-called American literature of this time was, may consult Mr. Tyler's History of

CHAP. III.

Note 22, page 122 .

Note 23, page r23.

Note 24, page 124. 
Chap. III. American Literature, or Mr. Stedman's Library of American Literature.

Note 25, page r25.

The custom of making a library by transcription prevailed among the lawyers in Edward I's day, according to Lord Campbell. Lives of the Chancellors, i, chap. xi, cited in Allibone's Dictionary, p. 1993. The Reverend Edward Taylor, of Westfield, Mass., in the last quarter of the seventeenth and the early eighteenth century, copied more than a hundred borrowed books. Nearly all his professional books were copied by himself, and " his manuscripts were all handsomely bound by himself in parchment." Sibley's Harvard Graduates, ii, 4ro. There are volumes of old Virginia statutes in the Library of Congress partly manuscript. As late as I7I 5 (chap. xxv) Maryland enacted that all acts pdssed should be transcribed on parchment and sent to each county, to be lodged with the clerk after they had been "published and proclaimed in court.". A like $\mu$ sage prevailed in other colonies. The Mennonites in Pennsylvania were advised from Europe to transcribe the colossal Martyr Book for their own edification. Many examples of books written which were never destined for print might be given. President Stiles's manuscripts and those by William Byrd, of Westover, are notable examples. In my own collection are manuscripts some of which seem to be sixteenth century copies of books probably in print, others are manuscripts of the seventeenth century not intended for print. There are also manuscript books on various studies, especially geometry and surveying, that appear to have belonged to old New York families. The custom of college students making manuscripts came with the first settlers. Massachusetts Historical Society Collections, vi, I02, I03. 
CHAPTER THE FOURTH.

WEIGHTS AND MEASURES OF CONDUCT.

I.

IN recent times the preconception that gives its color to moral judgment is the belief in an equality of rights for all. To do justice to the weak, to defend the helpless, to free the enthralled-this, in a nutshell, is the moral passion of the present age; a passion which sometimes obscures other phases of human duty. But when English settlers first broke ground in the New World the prevalent notions of life and obligation were everywhere monarchical and aristocratic. Primary duties were to those above you-to God, to the king, to the magistrate, to the social superior. Special privileges and exemptions rightfully belonged to the man of high birth and official position; worship and authority were theirs by divine right. "Noble or Gentle-men," says the author of The Compleat Gentleman, "ought to be prefered in Fees, Honors, Offices, and other dignities of command and government, before the common people." This Comp., for example, Cotton's Abstract of Laws, I64I, i, r, and iv, 3 . was the voice of the age, which even thought that rank exempted its possessor from challenge when he cheated or bore false witness. "We ought to give credit to a Noble or Gentle-man before any

Chap. IV. The aristocratic conception in morals.

Peacham's Compleat Gentleman, ed. I66r, pp. I4, 15 . 
Chap. IV. of the inferior sort. He must not be arrested or pleaded against on Cosenage." The intrusions of gentlefolk with hawk or hound into the fields of poor men were not to be resisted, however ruinous they might be. "They ought to take their recreations of hunting and hawking, etc., freely without controul in all places." This rather abject reverence for superiors extended to domestic life.

Comp.

The Husband's Authority Unvailed, 1650, p. 77 .

Conn.

Records, i, 72, 1642 . Comp. p. 80 and Mass. Rec., passim.

Reverence for rank.
The shining virtue of a wife was obedience ; resistance to a husband was rebellion against God. The son served his parents in menial subjection; in some houses he was required to attend them at table as a servant. He was often sent to play serving man to some greater kinsman, in order to learn the etiquette of subjection to superiors. When the well-trained lad encountered his father or mother he did them reverence and said, "Sir," or "Madam, I crave your blessing." In such an age it was easy for New England lawgivers to revert to the severity of the Mosaic law against disobedient children. Harsh penalties were denounced against " child or servant convict of any stubborne or rebellious caridge against their parents or governors," and incorrigibleness was "adiudged to be a sin of death" by Puritan lawmakers.

II.

Not only reverence for parents and masters, but the sentiment of reverence for rank was brought to America, and cherished as an inseparable element 
of piety. Subordination to social superiors was CHAP. IV. accounted the only basis of order. Distinctions were nicely marked; it has been estimated that of the emigrants to New England before I649, about Judd's Hadley, one in fourteen was entitled to the prefix of "Mr.," the rest were called simply "Goodman So-and so." Harvard students took their place in the catalogue according to the social position of their parents as appraised by the academic authorities, and the lad of humbler birth yielded the baluster side of the stairs to one conventionally his superior. The seats in New England meeting-houses were formally "dignified," a process by which their relative value as a mark of rank was fixed, and it was then decided by carefully weighing against one another the various offices in town and church and trainband, as well as by comparison of estates, who should sit in the places of honor. Social aspirants seeking to advance themselves by intruding into seats higher than those assigned to them, created disturbance in the meeting-house, and their ambitions had to be repressed by fines. In the Chesapeake colonies emblems of rank were sometimes attached to the pew of a governor or other officer, and the great families of the parishthose from whom justices of the peace and vestrymen were chosen-were wont to lend the countenance of good society to divine worship from exclusive pews perched high in the gallery under the roof, like swallows' nests, or placed at some point of conspicuity on the floor below. For 
Chap. IV. humble people to dress "above their degree" was clearly sinful, because "they that wear soft clothResults of ing are in kings' houses," according to Scripture. Three

Synods, 95, 97. Comp.

Perkins,

Cases of

Con-

science, I39, 140 .

Note $\mathbf{r}$.

Maryland Archives, i, 7 r.

Mass. Liberties, 43.

So declared the New England Synod of 1679 , which stigmatized the rising of a democratic spirit at that time as "a refusing to be subject to order, according to Divine Appointment." It was even in accordance with the notions of the time that the scales of justice should slant a little toward a plaintiff or defendant of dignity, and a high-born felon did not lose the benefit of his birth. In Maryland, for example, the criminal of quality was to be beheaded according to English precedent, and not hanged like a vulgar rogue, while Massachusetts politely refused to send "any true gentleman" to the whipping-post.

In the colonies generally the dignity of a ruler was guarded like the ark of the Lord, and a spectacular show of reverence was made to judges and governors by means of escorts of gentlemen or sergeants with halberds. Criticism of magistrates in the early colonial period was little less than blasphemy. Pitiful was the case of a Mrs. Oliver, whose opinions were too large for a narrow time. Publicly whipped for reproaching the Massachusetts magistrates, this brave woman of rare gifts Savage's bore her cruel chastisement without binding. Winthrop's Journal, i, 232, 233.

Clap's Memoir.

Years afterward her animadversions on the clergy were cleverly refuted by pinching her tongue for half an hour between the forks of a cleft stick. A poor devil of a servant, who ventured to reproach 
the magistrates in 1631 , had his plebeian ears cropped. "I saw it done," says Roger Clap with righteous exultation. If Cotton's scheme had been adopted in $164 \mathrm{I}$, all unpleasant criticisms of God's appointed would have been strangled outright by the hangman's rope.

\section{III.}

This upward trend of moral obligation was associated with a more fundamental notion. The age summed up its body of ethical doctrine in the compact statement that "the chief end of man is to glorify God." This doctrine, lisped by babes and sucklings, found its counterpart in the declaration of the famous Westminster Assembly, that the only living and true God "works all things according to the Counsell of his owne . . . Will for his owne glory." Men were taught to be good, not from any aspiration for honesty or goodness, nor out of any regard for the rights and welfare of others, but solely with reference to the will and pleasure of God. "This Good Pleasure or Will of God is the rule of Righteousness," says John Norton, the Massachusetts Calvin. The moral law was made moral by divine command; theft would not have been wrong had there been no commandment. "That the moral law should be a constant rule of manners," says Norton, " is from the Meer Will of God."

IV.

We have intruded here into the region where "reason builds beyond Nature, but into emptiness

Chap. IV. Cotton's Abstract, vii, $\mathbf{I}_{3}, \mathrm{I} 4$. Mass. Hist. Coll., vol.i. Comp. Code of MIass., 1649, 143 .

Theocratic ethics.

The Humble Advice of the Assembly of Divines concerning a Confession of Faith, chap. iv.

Note 3. king. 
GHAP. IV.

only," as Schiller has it. But many practical consequences were deduced from the speculative notion of God as a despot who was the arbitrary source of right and wrong and who sought nothing but his own glory. It was the period of emblemism in theology, the period of the doctrine of correspondences in philosophy and of signaturism in medicine. To the mind of the time a clever metaphor was more convincing than an argument, and

Compare

T. B.'s

Royal

Charter granted unto Kings by God Himself, I649.
The state secondary to the Church. an analogy was almost irrefutable. Passive obedience to the reigning sovereign was fortified by the prevailing conception of right and wrong as dependent solely on the pleasure of the Deity. But the great leaders of Puritanism, finding their plans opposed by royal authority, cleverly succeeded in making the rule work the other way. From the notion of God's relation to morals they evolved an ideal of theocracy. Divine sovereignty became a cover for latent disobedience to the king. "The allegiance we owe to our dread sovereign lord King Charles" is the courtly phrase of Cotton, but while he thus doffs his hat to the king with his right hand, he furtively opens a back door of escape with the left, by adding the ambiguous saving clause, "whilst he is pleased to protect us as his loyal subjects."

V.

Puritan theory was strangely akin to ultramontanism in one regard. It made the state secondary and subordinate to the Church. Cartwright, the 
great Puritan of Elizabeth's reign, had embodied CHAP. IV. this in the maxim, "No man fashioneth his house to his hangings, but his hangings to his house"; and Hooker, the founder of Connecticut, was fond of repeating the proverb. When he shaped the Note 4. Constitution of that colony in 1638 he made the government an humble auxiliary of the churches. Cotton found in the Scriptures a complete and infallible platform of politics, and of half a dozen other things besides. By what picking and snipping of texts he succeeded in getting whatever was desirable from the Bible we may see in his proposed code, to many of the provisions of which he appended Scripture references. That a court of law should have a clerk seems clear enough without a proof text, but Cotton must needs bolster this obvious expedient of common sense by citing the fact that there was a scribe's chamber in the court of the king's house in the time of the prophet Jeremiah.

VI.

The analogy between monarchy and divinity was so strongly felt that one is not surprised to find in the last will of Hooker, the founder of Connecticut, that God is called "His Majestie," and the same term occurs in more than one local record of the time in England. It was to conciliate this Abstract of Laws, i, 6. Jeremiah, xxxvi, Io, I2.

Defense of divine dignity.

Conn.

Rec., i, 500. Royal Hist. MSS. Com. Reports. dread potentate that blasphemy was suppressed in laws and military orders, and the prevailing notion of the austere despotism of God had much to do 
CHAP. IV. with the unrelenting persecution of heretics as his sworn foes. This cringing attitude toward a jealous God appears in the fine-spun inhibitions of constructive idolatry. The success of difficult enterNote 6. prises was thought to be secured by the suppression of heresy and blasphemy. Captain John Smith undertook to abolish swearing even among the rude and calamity-smitten Jamestown emigrants; but he did it not by Puritan severities, but in a jolly, rough-and-ready way by pouring cold water into the sleeve of the swearer. Varying penalties were denounced against swearing in $\mathrm{New}$ England; the profane man was fined and set in the

Conn.

Rec., 1640, I649.

MS.

Records Accomac Co., Virginia.

Sewall's Diary, i, 4. stocks. One Connecticut blasphemer was to have his second whipping in the January following his first, "except the governor judges the weather unseasonable." In early Virginia records the fines for swearing are from one to three shillings, and in one case, in 1634 , the parson is the prosecutor. A Harvard student, who had spoken words regarding the Holy Ghost which were thought blasphemous, was publicly solemnly beaten; the punishment was preceded and followed by prayer, a kind of grace before and after. The student's offense lay probably in the expression of unorthodox opinions, the most atrocious kind of blasphemy. He was subjected to other indignities after the beating, either to convince him of error or to propitiate an offended Deity. It was an accepted theory with ardent religionists, whether Catholic or Protestant, that heretical opinions regarding God 
should be punished with death. A denial of the Chap. IV. divinity of Christ was a capital offense under the early law of Catholic Maryland, and in later Protestant Maryland any objection offered to the doctrine of the Trinity was to be punished by boring the objector's tongue; for a second offense the Unitarian was branded on the forehead with $B$ for blasphemy; the third time he was to be put to silence forever by the last resort of the law. New York, in its first year under English authority, denounced death against him who should deny "the true God and his attributes." Inhumanity and injustice were not absent from the colonial codes, but the "rights, immunities, and privileges" of Almighty God were always guarded.

\section{VII.}

This apparent excess of reverence has ever a basis of self-interest, quite cold-blooded and undisguised. The very buccaneers of that age went to prayer and confessed their sins whenever a rich prize hove in sight ; and early Virginians sent expeditions against the Indians with general orders which usually began with a prohibition of profanity, or some other precaution for securing the favor of Heaven. The Virginia Company thought the Indian massacre of 1622 due to the "sins of drunkenness and excess of apparell" in the colony. The Massachusetts Company in London wrote to Endecott, in charge of their pioneer, settlement, to "make good laws for the punishing of swearers" Self-interest in morals.

Comp. Hist. des Filibustiers, pp. $45,54,55$.

Bacon's Laws of Md., I 726, xvi, i.

Duke of York's Laws, so called, i664.

Note 7.

Randolph MSS. in Va. Hist. Society. Young's Chronicles of Mass., I89. Compare 
CHAP. IV. and other offenders "if you ever expect a comfort Vaughan's Directions for Health, I602.

E. E. T. Society, $\mathrm{v}$, $25 \mathrm{I}$.

Letter in Bradford's Plymouth, 277.

Plymouth Rec., v, I77. or blessing of God upon our plantation." The first church was organized in Massachusetts during an epidemic, "to pacify the Lord's wrath." Winthrop, in his journal, is able to point out the particular sin that provoked almost every calamity of fire, illness, death, and financial loss that befell any individual. One man, for example, ventured to work too late on Saturday evening, the beginning of the Puritan Sabbath, and his child forthwith fell into a cistern on Sunday night and was drowned. In the time of King Philip's Indian war the obliteration of a town by firebrand and tomahawk was traced, not to the lack of a blockhouse and a vigilant garrison, but to the doomed town's neglect to secure "an able, faithfull dispenser of the word of God." The blight of 1665 that extinguished all hope of wealth from the growth of wheat in Massachusetts was attributed by the common people to the execution of the Quaker martyrs, and the Indian wars of 1676 and 1677 were thought a punishment for persecuting laws. But the conservative

Mass. Rec., v, 59 .

Archdale's Carolina, 30.
Scruples about idolatry. party proceeded in the latter year to make the laws against Quakers more stringent. Archdale, the tolerant Quaker Governor of South Carolina, thought that a pestilential fever in that colony was due to the persecution of dissenters.

\section{VIII.}

In the seventeenth century there was much fear of lapsing into idolatry by inadvertence. Lord 
Bacon recommends the pouring of wine into newly Chap. IV. dug earth for the remedial effect of the vapor, but he adds the caution "that it be not taken for a heathen sacrifice or libation to the earth." The clause in the Massachusetts Body of Liberties of 164I which made it a capital offense to have "any other god but the Lord God," could have had no practical aim unless it was the suppression of constructive idolatry. Many members of the trainbands in that colony regarded the English ensign as a gross idol, and refused to march behind it, because it had a cross in it. Endecott, the New England Jehu, thinking three fourths of a cross no cross at all, cut off one arm of it in the Salem colors. Hooker wrote a paper to prove the ensign harmless; but the rising zeal against idolatry obliterated the cross of St. George from the colors of the trainbands in 1635 . After this reformation the red flag had only a white field in the upper corner for a union. For similar reasons the early Puritan settlers omitted the prefix "Saint" from familiar geographical names. Fór long generations Englishmen had paid rents and wages on the penultimate day of September, when the harvest was fully in hand. For such purposes it had been the habit for ages to count the year from Michaelmas to Michaelmas, and the term could hardly be spared. In Connecticut it was Protestantized into Miheltide, so that neither mass nor archangel might get any good of it. In the first half of the seventeenth century, and later, there were scruples iii, 2.

Win-

throp's

Journal, i,

I86, 189 , note, 224, 225. Mass. Records, 224 and elsewhere. Stoughton's letter in Mass. Hist. Soc. Proc., r86r, $\mathrm{x} 35$.

Sewall's Diary, ii, I2. Danker's Journal, L. 1. Hist. Soc., i, 393.

Conn. Rec., i, I82, x649. Comp. Ben Jonson's Alchemist, 
Chap. IV.

against using the ordinary names of months and

Win-

throp's

Journal

and others.

days of the week on account of their pagan deriva-

tion. Ordinal numbers were introduced instead to

avoid etymological idolatry. "In Boston," said the royal commissioners of Charles II, "neither days, months, seasons, churches, nor inns are known by

Sewall's

Diary, $1696, \mathrm{i}, 428$. their English names." The practice of numbering the days gradually passed out of fashion, after it became a badge of Quakerism. Efforts to revive it in the last years of the century were vain. The pinch of the inconvenient scruple was got over by a trick of words: the names of the days were

Mather's

Ratio

Disciplinæ.

Bozman's Maryland, ii, 403, 404 . purified from idolatry by being called "planetary names"; but colonial New England continued to refuse to speak of "the Lord's Day" as Sunday. Puritan refugees from Protestant persecution in Virginia refused to take an oath of fidelity to the government of Maryland, because the officers of Maryland had sworn not to molest Roman Catholics, and what was that but swearing to countenance and uphold Anti-Christ? And so by many links, through their oaths to the government and Church and through the governors and their oaths, and through the unmolested Catholics with their saints and images, these tender consciences would at last be drawn into a long-distance paganism.

Not only was there danger in those perilous times that the individual might fall into damnable idolatry without knowing it, but the Puritan governments were ever on the alert to keep the land 
from being polluted by heathenism. Soon after CHAP. IV. the earliest settlement of Massachusetts, Governor Endecott cut down one false god, the maypole at Merrymount. A few years later, in $16_{33}$, the Massachusetts General Court went further and prohibited the natives from practicing their ancient custom of powwowing in the land of their forefathers. Weird dances, accompanied by gourd rattles and punctuated with grunts and inarticulate cries, were naturally taken for worship of a false god or of a devil. The Virginia Company had much earlier proposed to capture the Indian medicine men and thus put an end to such heathen mysteries. The ancient maxim that "dominion hath its foundation in grace" was accepted in the earliest colonies, and hence Christians dominated pagans by right divine. One writer intimates that some of the Virginia planters, about the middle of the century, carried their Christianity so far as to believe that a pagan had no right to property for which a Christian might have use.

Gatford's

Public

Good without Private Interest, I657. Comp. Young's Chron. of Mass., 387.

IX.

The sense of moral proportion was obscured and confused in a reverent dread of offending God. The prevalent English custom of drinking healths was deemed "an abominable practice," and put under ban in New England, and later in Note 8 . Pennsylvania, not for the promotion of temperance alone, but mainly because it was a profane mixing

Trifling offenses magnified. 
CHap. IV. of prayer and drinking and "a vain custom." It was also "an occation of the wasting of the good creature" at which the Creator might take umbrage. In 1643 the Virginia law made the evil of Hening, i, 240.

Conn.

Rec., i, 289. "the loathsome sinne of drunkennesse" to consist partly "in the abuse of God's good creatures," and this pious phrase has left its trace down to our time in a cant name for strong drink, "the creature." In modern times the objections urged against gaming turn upon the supposed danger of falling into the vice of gambling. The Puritans were at much pains to explain that the chief sin in games of chance was one of profanity. The lot was "an appeal unto God," and games of chance were therefore declared by the Connecticut General Court to be "altogether unlawful in the very nature of them," since in cards and dice "that great and sollemne ordinance of a Lott is expressly and directly abused and prophaned." Cotton even unlimbered his scholastic logic to prove that the merry nonsense of choosing mates on Valentine's day by drawing papers from a hat was an appeal Hutchin- to God's “immediate providence for dispensing son Pprs., I 82,183 . Code of 1672, 37, 38. Comp. Mass. Rec., 163I, p. 184 , and these ludicra," and hence " a taking God's name in vain." To check "the great dishonor of God" that was wrought by games, the Massachusetts Legislature, in 1670 , excluded cards and dice from the colony as things pernicious in their very nature. The observing of Christmas was objectionJudd's Hadley,98. able because it was an occasion for the profanity of playing games. But Christmas observance 
was iniquitous on its own account, for all honoring of times and seasons other than the Sabbath seemed to the finespun Puritan mind a masked idolatry. It was ordained in Massachusetts, in 1670, that the mere abstaining from labor on the $25^{\text {th }}$ of December should be a penal offense. By this system of far-fetched deduction innocent acts were made technically superstitious, while intolerance and superstition, with consequent cruelty to "heretics" and "witches," walked abroad unabashed in garments of sanctity.

$\mathrm{x}$.

When the early English settlements were made in America, the observance of a strict Sabbath was a newly discovered virtue brought to light in the later Reformation period. Never before was a new obligation so swiftly and widely accepted as was strict Sabbath keeping in England and Scotland. Several things had prepared for this acceptance; nothing had done more than the recoil of religious people from the coarse and brutal amusements that made the English Sunday of Elizabeth's reign a school of frivolity and cruelty. From morris dancing, from intolerably coarse interludes, and from the pitiless baiting of bulls and bears, the reaction to severe restraint was natural. Like all other novelties of the new century Sabbath keeping was impatiently exported to be tried in the virgin communities of the New World. A severe

Chap. 1V.

Note 9 .

Sunday in pioneer Virginia. Note ro. Note $\mathbf{r}$. See The Beginners of a Nation, book ii, chap. i, sec. $\mathbf{x x}$. 
Chap. IV.

Stith's Virginia, 148 .

1618.

Smith of Nibley MSS., folio $6 \mathrm{I}$.

Note 12.

Sabbath was imposed on the infant Virginia colony in the relentless military code under which De la Warr, Gates, Dale, and Argall ruled. Argall, though a tyrant, a semi-pirate, and a finished despoiler of other men's estates, was religious none the less; the combination was not uncommon in that time. Under this versatile master of rapine the colonists were required to be religious willy nilly. He who did not go to church on Sunday must "lye neck and heels"- - that is, with chin and knees drawn close together - " on the corps du gard " the following night and be reduced to slavery for a week. If this did not take the atheism out of the culprit, a harsher penalty was visited on succeeding offenses. The sub-colony sent to Virginia in 1619 by the estimable Smith of Nibley and his associates was provided with instructions which required that "vain sports bee refrained" on the Lord's Day, which was to be observed with "divine exercises according to the common prayer." James I had tried to check the tide of Sabbatarianism, but his so-called Book of Sports had precisely as much effect as the memorable command of his remote predecessor Knut against the incoming sea. He never learned that great lesson of statesmanship that once Humpty Dumpty is down the king himself can not replace him. James tried to compel Englishmen to amuse themselves on Sunday as in former times, but we find this company of good churchmen spurning his "vain sports" in their general orders, and sending copies of the 
"Practice of Piety" along with the prayer book to ChaP. IV. teach the emigrant subjects of the king an opposite doctrine. Bishop Bayly's Practice of Piety was much read in Virginia during the seventeenth century, and it gives seventy-five pages of its small bulk to enforcing the duty of sanctifying the first day of the week. Beside the forbidding of all business and burden carrying, it is particularly severe on the "trimming, painting, and pampering" of one's self on Sunday, which is "doing the divel's work vpon Grod's Day." Bayly also forbids "Studying any Bookes of Science but the holy Scripture and Divinitie," and "all recreations and Sports which at other times are lawful," with "all grosse feeding" and "all talking about worldly things." This view of duty was enforced by arraying the very same horrible examples that had served in Bownd's famous treatise on the Sabbath. See Beginners of a Nation, pp. 124Did not the scaffolding fall like the tower in I33. Siloam and kill the people at a Sunday bear baiting in London? And this not at all on account of their inhumanity to the bear, but solely because they were enjoying "carnall Sports on the Lord's Day." Dr. Bownd's nobleman whose hunting on Sunday caused his child to come into the world with a dog's face reappears in Bayly. A disas. trous conflagration in Stratford-on-Avon and a peculiar combustibility in other towns with Sunday fairs were also edifying examples of the danger of obeying King James in this regard. But whatever effect such dire examples may have had on the seri-

Twentyfifth edition Delft, p. $303 \mathrm{ff}$. 
Chap. IV.

Secular culture in Virginia.
IIammond's Leah and Rachel, I656. ous minds of pious men and women, the great majority of early Virginians took their Sundays without fear of divine judgments and without regard to the Sabbath law of the colony passed in $\mathbf{I} 643$. Many of them spent the day in gregarious and demoralizing idleness.

XI.

Here we come upon those forces that made the culture of Virginia as distinctively secular as that of New England was dominantly theological. There were physical difficulties obstructing religious observance in the Chesapeake region, where habitations were thinly strung out along the estuaries, rivers, and tributary creeks-mere sinuous lines of water side settlement with only forest behind. There were plantations that had never an entrance or exit by land. Some parishes were thirty miles and more in shore length, and when the web-footed pioneers would attend church they must commonly do it by sailing in their sloops or by laborious paddling in dugouts. After the passing of Hunt and Whittaker and other brave missionaries of the first generation there came a different race of clergymen, "such as wore Plack Coats, and could babble in a Pulpet, roar in a Tavern, ... and rather, by their dissolutenesse, destroy then feed their Flocks." The church was far away, the parson contemptible, but no doubt some of the isolated settlers resorted to service to meet their neighbors and relieve the tedium of loneliness. 
But many of the younger Virginians, and those of CHap. IV. the rougher class, generally preferred to spend the idle day of the week at the nearest Indian village in rude amusements and intercourse with the barbarians. There was a considerable betterment of manners in the times of the English Commonwealth, when exiled Cavaliers brought in a more dignified way of living and a better regulated Sunday. Throughout the colonial period the Virginia Sunday was never a rigorous Sabbath, but mainly a day of leisure, of sport, and of social enjoyment, with resort to the Church service when convenient. The typical country squire of the Chesapeake region treated religion as a mere propriety, by no means to be taken too seriously; there were many in the eighteenth century who rejected it altogether It came to pass, thus, that tiae Virginia mind was coolly secular and unspeculative-an intellect trained to affairs, and above all to politics and social intercourse. Virginia's early contribution to the intellectual life of the country was naturally a political one. The difference between the outcome of colonial Virginia and that of colonial New England might almost be anticipated by observing the wide difference between the early Virginia Sunday and the Puritan Sabbath. New England was cradled in religious enthusiasms that gave tone to life in the whole northern belt of the United States. If Virginia and the States of her planting have lacked that reformatory zeal which has made New England so generally serviceable, 
Chap. IV. and sometimes so tedious, it is probably because Note 13. Virginia was almost untouched by any strong religious sentiment, until it was at length stirred by the evangelical movement in the middle of the eighteenth century.

\section{XII.}

The New England Sabbath.

Note 14.

Mass.

Records, I653, vol. iii, 316.
Although the keeping of Sunday with sabbatical strictness began soon after the Reformation in some parts of England, the doctrine made no great stir until Dr. Bownd's elaborate work on the Sabbath of the Old and New Testament burst upon an astonished public in 1595 , and by its boldness brought down upon itself condemnation to the flames and the prohibition of further issue. Ecclesiastical and governmental interference helped to make a painfully rigorous repose on Sunday a distinctive badge of Puritanism. The Sabbath in the superlative degree crossed the high seas with the Puritan migration. In New England it was argued that, as the Sabbath was the principal outward means of honoring God, it stood for the whole duty of man toward God. And a right divine reverence was paid to it. Contrary to English custom, the greatest Puritan divines, Cotton and Hooker, maintained with consistent literalness that the consecrated time began at sunset on Saturday evening, because the Jewish Sabbath began on Friday, and the evening and the morning made a day in the first chapter of Genesis. Judaism sat hard on the Puritan conscience in many ways; 
even the Jewish preparation for the Sabbath was imposed on the people in the first years of New England. "All that inhabit the Plantation" were ordered, in 1629, to "surcease their labors every Saturday throughout the year at three o'clock." The rest of the day was given to catechising and other painful preparations of the soul for the irksome austerities of the Sabbath. In mediaval times mortifications of the Hesh were sometimes savagely severe, but they were voluntary and affected only the individual inflicting them upon himself. Puritan austerities were imposed by family authority on servants and little children, and enforced with ruthless severity on a whole community by the magistrate. On the Sabbath cattle might not be pastured in the common field where they would have to be watched, food must not be prepared, nor must one pay a visit or walk in the streets or the fields except to meeting, nor might one stay at home from meeting without danger of fine or whipping-post. In New Haven, and probably elsewhere, indulgence in eating an apple or cracking a nut was accounted reprehensible. In solemn awe of the Sabbath the innocent gambols of the children were repressed as something particularly heinous. "We should rest from labor, much more from play," says Cotton in a catechism ludicrously entitled Milk for Babes. The aged Increase Mather, as late as I712, urged that children must not be suffered to play on the Lord's Day. Of rest the Puritan mind had no
Chap. IV.

Instructions to Endecott in Young's Chron. Mass., $16_{3}$, with note and authorities there cited.

Lambert's New Haven, I88 and elsewhere.

Milk for Babes, in Prince Library, Boston. Mather's Meditations on the Sanctification of the Lord's Day. 
CHAP. IV. conception; it was a technical term that included the attending to public prayers, stretching sometimes to a full hour in length, and to sermons of yet greater prolixity, interspersed with home exercises to fill up the time and banish repose. The leaders were generally sincere enthusiasts bent on pleasing God and not even comprehending what a huge burden of unbearable Pharisaism they were binding on the backs of men. Probably nothing else in Puritanism, not even its hatred of heretics and its horror of witches, caused so much human unhappiness in the aggregate as did its effort to transform the Christian Sunday into a punctilious Hebrew Sabbath. For the attainment of this end almost every sort of outrage on personal liberty was perpetrated by the magistrates

Cal. Col. Papers,

State Paper

Office, 1660-'68, No. $5 \mathbf{I}$.

Lambert's New Haven, I93, note. and by domestic authority. Even foreigners presumably ignorant of the law were liable to arrest and other indignities, if caught strolling in the streets of Boston on Saturday evening after sunset. Ambassadors from a French Catholic colony were shut into Winthrop's house the entire Sunday for fear of collision with public opinion and the constables. This polite incarceration was mitigated by "the liberty of a private walk in the garden." In New Haven, in I647, a young man was sent to the whipping-post on Monday for not going to meeting on Sunday, and two brothers were beaten by their father for visiting young women on Saturday after sunset. They lived unmarried to their deaths from mortification. Much of the 
torture proceeding from the Puritan Sabbath was self-inflicted. There is a pitiful story of Wigglesworth, the author of the popular Day of Doom, sitting long on a windy Sunday in an agony of scrupulous uncertainty, unable to decide whether he might with a good conscience venture to go and shut a neighbor's swinging stable door and so save it from wreck. He ended by leaving the door to its fate for the Lord's sake.

The yoke of bondage enforced by law galled the necks of those who were less religious or who held to the easier habits of the Church of England. There were many in the first generation who "accounted it their happiness to live in the wast howling wilderness" to escape this unblinking supervision, giving up many advantages to preserve that liberty so dear to men not broken by oppression. Later in the century there was a party that denied the right of the colonial government to enforce the Sabbath and prescribe modes of worship. An election sermon was leveled at this uprising, and the Synod of 1679 even shakes at it the old superstition used by Dr. Bownd in I 595, and later in the Practice of Piety, that conflagrations are intimately connected with lax Sabbath observance. And indeed the New England Sabbath, though almost too much for flesh and blood, had by this time become a fixed tradition, good for yet more than a hundred years of survival before it should begin to show signs of decline. In 1740 we find it still the custom to shut the gates of the Boston peninsula and to put

Chap. IV.

Sibley's Harvard Craduates, i, 268,26 ).

Chauncey's Commencement Sermon, Cambridge, I655.

James Allen's Election Sermon, I679. Results of Three Synods, I00. Note 15. 
CHAP, IV.

Bennett MS. in Mass. Hist. Soc. Proc., I86I, II5.

Sunday in Maryland.

Md.

Archives, i, $83,1639$.

a guard at the ferry, that no one might go forth on Sunday. And the traveler who gives us this account of the state of siege in which Boston put itself once a week adds that if " they could escape out of the town, it wouldn't answer their end; for the same care is taken, all the country over, to prevent travelling on Sundays . . . They will not suffer any one to walk down to the water side, though some of the houses are adjoining to the several wharfs, nor even in the hottest days of summer will they admit any one to take the air on the Common... The justices, attended with a posse of constables, go about every week to compel obedience to this law." Even a group of two or three might not talk together in the street on Sunday. Thus uneasily with wearisome diligence and infinite watchfulness did the New England metropolis take its rest. There is a reverse to this picture of strait-laced government that is more agreeable. The traveler just quoted tells us "it is a rare thing to meet with any drunken people, or to hear an oath sworn, in their streets."

\section{XIII.}

In Maryland the early law regarding Sunday was Catholic in tone ; work was forbidden on " the Lord's Day or other holy days." This modest prohibition may have been tolerably well observed, for the roistering settlers were ready enough to abstain from work on any day of the week when 
excitement could be found. But the law probably Chap. IV. bound them little; certainly they freely disregarded the act passed at the same time against "drinking to a notable perturbation of any organ of sense or motion." There were pious Catholics who spent their Sundays becomingly, no doubt, and there were many Puritans in Maryland whose Sabbaths were characteristically strict.

In the Dutch colony of New Netherlands many laws were made regulating the sale of liquor on Sunday, and in 1663 a bill was passed in favor of a strict Sabbath, but against this New Amsterdam protested, and refused to proclaim the law, as contrary to the freedoms of Holland. It would have been impossible to enforce a strict Sabbath on the mixed population of residents and the yet more varied comers and goers in New Amsterdam. The Dutch, says Sir George Mackenzie, have "few Merchants and Tradesmen who do not sell and work freely on the Sunday."

Note 6.

In the

Dutch colony.

Dutch Manuscripts, vol. $\mathrm{x}, \mathrm{pt}$. iii, rig. O'Callaghan's Laws of N. N., 448. Moral Hist. of Frugality, $\mathrm{x} 690$, p. 20.

XIV.

Religious zeal was abundant in the seventeenth century among devout people of all creeds, but it Zeal without pity. lacked that touch of generous pity that in more recent times would fain convert men for their own benefit. It was a zeal for church, for party, for faction-a zeal for sound doctrine as each sect understood sound doctrine. There was a disinterested zeal for the glory of God, or, as the devoted Catho- 
CHAP. IV. lic missionaries of Maryland phrased it, "for the glory of the Blood of our Redeemer." But men of all shades of opinion took pleasure in the disasters of obstinate opponents and unbelievers. Roger Clap does not conceal the pleasure it gives him that one of the gainsayers of the Massachusetts theocracy had probably been roasted alive by the Indians; and the same religious but ruthless spirit crops out in all churches and parties of the time in England and

Abbot's Letters in Egerton Pprs., 447, 448.

The religious societies.

Woodward's Rise of the

America. It was not Laud, but his predecessor and opponent, Archbishop Abbot, who took pains to secure the burning of two heretics by packing the court with judges already pledged to decide against the accused. The undertone of philanthropy that we confidently expect to find in religious feeling in recent times was lacking in the fiercer and, if we must say so, more religious spirit of that day.

\section{XV.}

In order better to mark the distinction between that age and this later time, let us digress to trace, along one of several more or less obscure lines of cause and effect, the evolution of altruistic zeal. When that tide of frivolity and scoffing profligacy that overflowed English life at the fall of the Commonwealth and the return of Charles II to the throne had swelled to the full, there sprang up in some London parishes, about 1679, "religious societies." By whose agency the first were planted, or whence came the seed-thought, we shall prob- 
ably never know. Intended only to promote devoutness of spirit and seriousness of life in individuals, these little groups of brethren pledged to one another, and, solemnly taking the communion together in their own parishes, offered a warm and sheltered soil in which germinated those ideas that formed the religious life of the eighteenth century. By a gradual modification some of these associations appeared in $169 \mathrm{I}$ as the famous societies for the reformation of manners by appeal to the law. Their most effective work was done in Queen Anne's time. This' tendency to do by means of societies what the half-palsied English Church of that time could not do, resulted in 1699 and the following years in the establishment of societies for religious propagandism-both by printed publications and the sending of missionaries-a device by which Protestantism has sought to supply the loss of the mediæval religious orders. The outgrowth of the devout societies did not weaken their organizations. One of these nurseries of pietism at a much later time bore the nickname of the Holy Club of Oxford, and out of it issued the WesleyWhitefield revival-a revival that primarily sought not to build up any Church or sect, but to benefit the brutal and neglected by means of religious influences. Thus a zeal for pity's sake took the place of the old stern and pitiless passion for what was thought to promote the glory of God. White-hot agitations that assume wide proportions are gradually changed by the resistance they encounter, and

CHAP. IV.

Religious

Societies, $3^{d}$ ed., I 7 OI.

A Short Acct. of Several Kinds of Societies, 1700. WhiteKennett Library, London.

Acct. of Foundation of Soc. for Prop. Gospel, Appx. to the sermon of 1706 . 
Снар. IV. are modified by cross-forces, until their momentum spends itself in achieving what the first promoters Note 17. did not have in mind. Religious movements in this way become at length political and social forces. The "Great Awakening" in the eighteenth century was presently metamorphosed, in part, at least, into philanthropic and reformatory agitations. The wish to save men's souls became an aspiration to deliver them from oppression, to educate them, and free them from the hardships Note 18. of poverty. This outcome of the religious movement coincided with the philosophical and political tendency toward democracy, that played so conspicuous a part in the transformation of ideas that took place in the wonderful eighteenth century.

Plan of salvation in the Practice of Piety.

Comp. sect. ix above.

Wood's Athen. Oxon., i, 567.

\section{XVI.}

We shall not understand the age of colonization unless we look into its schemes of salvation which are in some sort an index of moral stress. Bishop Bayly's now forgotten Practice of Piety, "Directing a Christian how to walke that he may please God," shall inform us, as it instructed nearly all men in that time. Its teaching regarding the Sabbath we have already noted. Editions of this guide to godliness tumbled headlong from the press in a succession so rapid that the booksellers of the time became confused in attempting to number them. A minister complained in 1656 that the "generality of the Plebeians" held its authority to 
be "equal with that of the Scripture." Bunyan's watchdog conscience was awakened by it and Ben Jonson's mocking humor laughs at the veneration for it. Colonists frequently carried it to Virginia and elsewhere, sometimes in company with the Bible, the prayer book, and Barrough's Method of Phisicke, and throughout the seventeenth century it turns up frequently among heirlooms left to descendants by deceased planters, and in New England it was even translated into the Indian tongue by the apostle Eliot. A Virginian of the early period, while wrestling with the unsubdued wilderness for bread and meat, and trying to decide whether or not his malarial fever was to be treated as an "intermitting tertian" or " a continuing quotidian," or whether it was both of these combined according to the systematic Barrough, must also pick out in the intervals of business and the pauses between ague fits the proper way of saving his soul. The Practice of Piety explained it in such a fashion that no wayfaring man, be he ever so wise, could by any chance understand it. It was also complicated by a folding diagram. In order to please God the plain man must know "the essence of God in respect of the divers manner of being therein," and also the "attributes which are either Nominall or Real." That is to say, he must appreciate the "absoluteness," " simpleness," and "infiniteness " of Divine existence, and then must know five "relative attributes" besides. If the acclimating fever has not haply carried him off while he is mastering these

Chap. IV.

Jonson's

Gypsies, quoted in Int. to Braithwaite's Barnaby, I818, p. 77 .

Edition "Printed at Delfthaven for the good of Great Britain." 
Chap. IV. complexities and perplexities, he finds that he must

Note 19. likewise "competently know and necessarily beleeve" other scholastic propositions, finespun to invisibility all of them, regarding the nature of God. He is also required to know himself-not himself actually, but only himself as John Doe in certain theological relations and in a wholly impersonal way. Having now glorified God by knowing him analytically, he comes to the second branch, which is to glorify God by serving him. One looks for a treatise on moral duties, but we are in the seventeenth century. This service of God begins and ends in acts of devotion performed "privately," "domestically," and "publicly," with remembrance of feasts and a yet more scrupulous observance of fasts. Religious etiquette all! For closing so futile a life there are directions for dying with proper devoutness. Duties to one's fellows, such as fill the Sermon on the Mount, find no place in the outspread diagram of duties with which the book begins, and it is with difficulty that they find standing room in a few subsidiary parts of the work. The mediæval virtue of almsgiving, with an eye to the welfare of the giver in the next world, appears in traditional form with a Protestant tag to it: "Liberalitie in alms-deeds is our surest foundation that we shall obtaine in eternall life a liberall reward through the Mercie and Merits of Christ." It was with this end in view no doubt that well-to-do Virginians kept up a custom of Vestries. leaving exactly ten pounds to the poor of the par- 
ish, and this was the only bequest that was in every case described not in colonial currency or tobacco, but in sterling money. If we inquire into the reason for the marvelous popularity of Bishop Bayly's Practice of Piety we shall find it in the fact that the book was the fullest expression of the religious sentiment of the people in an age of transition. It was, besides, written with considerable vigor. So much was it esteemed in England that in some instances at least it was read aloud by those who watched witches as a counter sorcery to ChaP. IV. confound the devil. A change in the sense of moral proportion, the waning of a belief in diabolism, with a growing notion that the heavens are not wholly unpropitious even to men who do not understand all about divine existence and attributes, and keep fasts, have caused this once utterly popular book to fall into a fathomless oblivion. When with difficulty, after tedious searching of public libraries, one finds by good luck a copy of the Practice of Piety that has escaped the wastebasket, it is worn and torn by seventeenth century thumbing.

\section{XVII.}

“We han't glorified Grod as Grod," laments the preacher of the Massachusetts Election Sermon in Gentleman's Magazine, I83o, p. 26. I704. In the effort to please an austere God wholly intent on securing his own glory, the age lost in some measure what it could ill spare, the propulsion of religious sentiment in the putting forward

"Effectual Calling." 
Chap. IV. of civilization and the uplifting of the individual. Puritan writers made holiness merely relative, the result of a mysterious transaction between God and the soul, in which transaction the soul had little part. This holiness, according to Cotton, was so persistent that it might survive much base living.

Cotton's

Holiness of Church Members, I65o.

Day of Doom, strophe 92 . $\mathrm{He}$ instances Solomon. On the other hand, uprightness of life, not preceded by "effectual calling," was mere sin. Wigglesworth in his Day of Doom marshals at the bar of God a company of

\section{That loved true Dealing and hated Stealing,} Ne'er wronged their Brethren.

But these worthy men, whose like is none too common, are summoned only to be scorned and damned. "The Ninevites and Sodomites," they are told, had no such sin as theirs. "Their righteousness is sin," the Judge tells them, "whereas the same deserveth Shame and meriteth Damnation."

- Thus the ideal of morality itself is abrogated in order to "glorify God as God" in the damnation of civil honest men. Fortunately for the world, theories that controvert fundamental intuitions are likely to be only speculatively believed. Neither Cotton nor Wigglesworth could have been as bad as his theory; in practice they probably respected honest men and detested scoundrels regardless of Note 2o. theological considerations. But such speculations when they reached weaker natures would serve as pretexts for immorality. 
ChaP. IV.

XVIII.

"Take heed," wrote Herbert of Cherbury to a friend, in 1617 , "of superstition and blasphemy, The God of that and above all that you make not a worse God than yourself." (In these words he touched the weakness of the age: moral judgments were off their center when men adored a God worse than the worshipers. ) It seems like a paradox, yet it is true, that the more intensely religious a people were in that time the worse was their representation of the Deity. The great and long-continued popularity of Wigglesworth's Day of Doom in New England makes it good evidence in this case. His damnation scene is mediævally horrible:

They cry, they roar, for anguish sore and gnash their Tongues for horror:

But get away without delay, Christ pities not your cry,

Depart to Hell, there you may yell and roar eternally.

There are passages more ghastly than this, but why disfigure white paper with them? God is made the direct ruthless agent of physical torture everlasting, kept up for no conceivable end but his own glory. . . . "God's direful wrath, their bodies hath forever immortal made ... And live they must while God is just, that he may Plague them so." A popular versifier like Wigglesworth, and he bred up among pioneers and Puritans, may be thought to hold views more extreme than those of his age. But Archdeacon Hakewill, much esteemed 
Chap. IV. for learning and philosophy, could write the same Apologie,
etc., 1627, p. 572 . hath neede to be fed continually with wood and fewell. ... that burneth eternally without feed ... for that the breath of the Lords owne mouth doth blow and nourish it." The monarchical idea dominates the thought of the time. Hakewill does not shrink from comparing the ingeniously cruel torments which vengeful kings had inflicted on The same, their foes to God's punishment of sinners, and says 513.

Comp. also Tymme's

Silver

Watch

Bell, I625, pp. 90,91 , and many others.

Damnation of unbaptized infants.

Note 2I.

\section{XIX.}

Irresponsible infants were condemned to perdition by the ruthlessly systematic theology of the seventeenth century, and this also for the glory of the God who made them. The mediæval churchly doctrine that none could be saved without the sacrament of baptism had carried with it the harsh corollary that many infants were damned, some of them lost through mere accident or inadvertence. Cranmer's Catechism of 1548 declares that the children of heathen parents will be "damned everlastingly" for want of baptism, and in this he follows the Lutherans of the same period. In the next century Archbishop Laud, while affirming that baptism 
is necessary to salvation, declines to bind God to the sacrament, probably from his habitual dislike of constitutional limitations to sovereign power. But the popular belief remained, after the Reformation as before, that a child dying unbaptized was doomed. In the dark ages of Virginia and Maryland the parishes were very long-suffering in their dealings with tavern-haunting, brawling, and sometimes almost criminal parsons, apparently from fear of having their children grow up nameless heathens or die heirs of perdition for want of baptism. North Carolina had few clergymen even in the eighteenth century, and one finds the settlers plodding many rough miles, each with his covey of offspring, to intercept a wayfaring parson at some wayside spring and thus secure a chance of salvation for the young natives. Grovernor Eden of that colony wrote to the Propagation Society lamenting especially that "above fourscore" infants had perished unbaptized in the massacre by the Tuscaroras in 1712. This view of the massacre is rendered more picturesque when we remember that Eden was the governor who sheltered Blackbeard the pirate, and almost certainly shared his plunder.

\section{$\mathrm{xx}$.}

The Church of England divines feared that unbaptized infants might be damned because of some one else's fault, but the Calvinistic portion of the religious world was certain of the damna-

CHAP. IV. Laud's Conference with Fisher, ed. $x^{6} 73$, p. $3^{6}$

Byrd's Dividing Line, 1728 , passim.

Damnation of non-elect infants. 
Chap. IV. tion of non-elect infants, baptized or unbaptized. Even John Robinson, of Leyden, the sweet-hearted pastor of the Pilgrims, could not escape this horrible conclusion, though he seems to accept it with Note 22. a sore heart and averted face. It was the misery of religion in that day that good men worshiped a God less just and merciful than themselves. As The Prin- late as 1690 "the ministers of the Gospel in Bosciples of the Protestant Religion maintained agt. Geo. Keith. ton" published a defense of infant damnation in reply to a Quaker who disliked the doctrine. The Boston ministers did not, as the Anglicans did, leave a narrow fringe of uncertainty. They averred, as others of their school of thought had done long before, that an obscure phrase in St. Paul's most obscure epistle rendered it certain that some infants had already been damned for eating Note 23. the forbidden fruit by proxy before they were born. On the other hand, Wigglesworth, the doggerel Dante of pioneer New England, reserved the damnation of unlucky babes to make an effective Note 24. scene at the day of doom. The widespread circulation of his verses must have sown broadcast notions out of which every bereaved mother could build a tabernacle of perdition for her desolate soul. Minds so simply serious failed to see the bouffe grotesqueness of the speeches put into the mouth of the Divine Judge, whom Wigglesworth makes a little lower than a pettifogging country justice. The foredoomed infants argue their case rather cleverly, and, from a modern point of view, they get the best of it. But Christ, the Judge, has 
the last word, and when they remind him that while Chap. IV. Adam is saved they are damned for Adam's sin-

Then answered the Judge most dread,

God doth such doom forbid,

That men should die Eternally

for what they never did ;

But what you call Old Adam's Fall

and only his Trespass,

You call amiss to call it his, both his and yours it was.

This is followed by a disquisition on original sin, delivered by the Judge for the edification of the lost infants or to clear the minds of the assem. bled universe. The infants are assured that they are sinners, and can expect only a sinner's share, "for I do save none but mine own elect." The Strophe I65. colloquy, evidently growing embarrassing, is cut short by a verdict which reverts to the Judge's only reliance-the sin of Adam:

A crime it is, therefore in bliss you may not hope to dwell:

But unto you I shall allow

the easiest room in hell.

XXI.

Beautiful and merciful lives have blossomed and borne fruit under the shadow of harsh and repulsive beliefs. It would be easy to fall into the error of exaggerating the evil effects of creeds of iron. (At a certain stage of social development the severity of a dominant creed sometimes serves a useful purpose of repression where repression is needed.) The seventeenth century had inherited

Strophe I8I.

Note 26. devotion. 
CHAP. IV.

most of its harsh doctrines in some shape from the schoolmen or the Church fathers, and it set itself to forge them into formal creeds for its own enthrallment. The welding of doctrines into elaborate and systematic confessions and the writing of concise expressions of the quintessence of dogmatic theology in innumerable catechisms were regarded as a sort of heavenly vocation. Antique doctrines tinged with the barbarism of older ages, when thus formally propounded and authoritatively imposed, served to blur the ideal of even-handed justice and arrest the growth of humane sentiments. The gentler side of Scripture teaching was more or less obscured in an age when master teachers insisted on giving a perpetual divine authority to the sternest laws of the early Hebrews. It was an age that embittered its devotions by singing unsoftened the imprecatory psalms. It was a matter of obligaNote 27. tion to sing all the psalms, even such vindictive verses as these in the New England Bay Psalm Book of 1640 :

And let the prayer that he doth make

be turned into sinne;

Ps. cix.

His children let be fatherless and's wife a widow make.

Let's children still be vagabonds, begge they their bread also;

Out of their places desolate let them a seeking go.

The primitive ferocity of such prayers is not chargeable to Puritanism; the versifiers of the Bay Psalm Book had heard the Sternhold and 
Hopkins version sung in English churches from infancy, and had probably used it for their primary reading book in school. It had accustomed them to such lines as these:

Yea blessed shall that man be cald that takes thy children yong

To dash their bones against hard stones that lye the streets among.

Thus sang the Virginia and the Maryland churchmen, and thus also the New York and Carolina churchmen. The metrical version made by the poet George Sandys, once Secretary of the Virginia Colony, was far more elegant and was "set to new tunes for private devotion." But even Sandys will have the Christian in his closet pronounce a blessing on the men

That dash thy children's brains against the stones

And without pity hear their dying groans.

This non-Christian commingling of revenge and religion gave force to the hatred for heretics and embittered persecution and religious contests. Hear the bitter words of Ward, a New England minister, against the Irish rebels: "Cursed be he that holdeth back his sword from blood, yea cursed be he that maketh not his sword starke drunk with Irish blood," and so on breathlessly to the end. These words of Nathaniel Ward were printed in London in 1647 ; two years later Cromwell translated them into ghastly fact by the pitiless slaughters of Drogheda and Wexford. 


\section{The Transit of Civilization.}

Chap. IV.

Brutality in sports.

Note 28.

\section{XXII.}

The dash of fanaticism in the religion of the time and the narrow and literal adherence to the precedents found in the most ancient Hebrew Scriptures had something to do with the lack of humaneness in the law and its administration.' For this reason ecclesiastics of all schools were often more ruthless than laymen; they carried their pitiless severity up to the credit of their piety. Massachusetts clergymen protested in 1635 against Winthrop for a leniency that to the modern man seems severe. In the controversy with the Gortonists the Massachusetts clergy advised that men not properly subject to the colony should be hanged for constructive blasphemy, but the magistrates were wiser or less zealous. "The clerical profession, by its very nature, is more dominated by ideal considerations than others, and the severity of clergymen in governmental affairs is not necessarily from harshness of spirit, but rather from devotion to an ideal of conduct.] The pressure of religious feeling in former ages was often distinctly opposed to the sentiment of humanity. But the seventeenth century needed no religious persuasion to severity; it was not at all a humane age. Traces of mediæval barbarism are found in the laws, in the customs, and in the brutal sports of the people, as well as in the sermons and other ecclesiastical deliverances. For generations the thoughtless populace had taken a savage delight in seeing bulls and 
bears baited to the death with fierce dogs; in an Chap. IV. exceptional case a horse was turned over to be torn by mastiffs for the delight of the people. Bear baiting was the favorite way of spending the Sunday afternoon in Elizabeth's reign. One finds in a vicw of London in 1574 two buildings on the Bankside, "The Bowll Baytinge" and "The Bear Baytingre," carefully indicated as places of chief interest. After the scaffolding fell with fatal results at the bear baiting on Sunday in 1583 the people became superstitiously afraid of such sports on Sunday, but they were enjoyed on week days without suspicion of wrongdoing. Some of the later Puritans argued that as the animosity of animals to one another was the result of man's sin, men ought not to make sport out of it. The suffering of the animal is rarely alluded to in these debates; theology did not care for bulls and bears. Cockfighting had been for ages a reputable sport, highly praised by such men as Ascham, the tender-hearted school reformer, and it was practiced (annually or oftener) in schoolrooms apparently as a part of education. Against this also some later Puritans protested. As late as 1737 an English traveler says that Continental people were accustomed to complain of the cruelty of "the sports of our vulgar"-the very charge Anglo-Saxons are wont to make against the Spaniards to-day. Bull baiting and the tormenting of tame bears were not imported to America; bulls were too scarce and valuable, and bears were too plentiful and fierce. But the relish for inhumane

Beschreibung und Contrefacture der Vornehmster Statt der Welte, I574.

Compare the opinion of $\mathrm{Mr}$.

Perkins and $\mathrm{Mr}$. Bolton ... . concerning ... cockfighting, 1660. Harl. Miscell., vol. vi, 122.

Note 29. 
Chap. IV.

sports remained. Entrapped wolves were made to sell their lives in a bloody fray with mastiffs, or were tied to the tail of a wild horse to be kicked and dragged to death. Josselyn speaks of some large New England bird, which he calls a "cormorant," as making rare sport when wounded and turned loose to be badgered by dogs. Animals appear to have been preferably put to death by dogs. One finds Archbishop Sandys in Elizabeth's time trying to recover a "brinded dog," and complaining that he had never a dog with which to kill some bucks that had lately been given him. Puritanism was reformatory, though it could never go far beyond its age, and did not break the tether by which the great Cartwright in the sixteenth century had tied it to the temporal laws of the Jews. Massachusetts had gone to the limit by its creditable and ungrammatical law of I64I against "CruLiberty, eltie to any bruite creature which are usuallie kept 92. Comp. also 93 .

for man's use." The wild creatures were left without the pale for want of Mosaic precedent, no doubt. In Virginia and Maryland cockfighting was a gentlemanly and Christian amusement throughout the colonial time. The laws of the Puritan colonies show that the reformatory spirit in Puritanism had begun to soften a little the harsh cruelty of law and its administration at the time, but notwithstanding prohibitions against cruel and

Paige, Hist. of Cambridge, 217. unusual punishments, burning to death took place in Boston and Cambridge and pressing to death was resorted to in the witchcraft trials in Salem. 
Punishments more barbarous, if possible, were inCHAP. IV. flicted in other colonies. Legal torture to produce confession was in use in New Netherlands under Dutch rule. In Pennsylvania a gradual translation of Quaker theories of non-resistance into milder laws took place, and the administration of the law was less severe than the law.

\section{XXIII.}

The obligation of worship, as we have seen, was thought to be infinitely greater than moral duty. "The languishing and improsperous condition" of the Virginians after the Restoration was not attributed to the strangling of their commerce by the enforcement of the Navigation Act, but to the neglect of the people, mainly on account of physical impediments, to render to God with regularity "that publicke Worship and Service which is a Homage due to his great name." For this "sacriledge" the people were believed to be under a curse. In 1677 the Bishop of London took Virginia in hand and set about reforming a colony that by all accounts needed attention. He proposed that the thinly settled planters should be compelled to renounce the "profane custom of burying in their gardens and orchards," and forced to give up their habit of accepting such marriage as they could get from men not ordained, in a land where men in orders were exceedingly few, often dissolute, and frequently so far away as to be

Obligation of worship.

Virginia's Cure, r662, p. 4. Force, iii.

Cal. Col. Pprs., Nos. 337-339. Comp. 123. 
CHAp. IV. reached only by a tedious sloop voyage, down one river and up another. There were things in the colony infinitely worse than the Virginia graveyard at the back of the garden to preserve it from prowling wolves, and the conservation of social order by marriage at the hands of clerks and lay

Comp. Gatford's

Public

Good without Private Int., I657. Morgan Godwyn's Negro's and Indian's Advocate, r68o and many others.

Hugh

Jones,

Present

State of

Va., 1724 , pp. 68,69 .

MS. Records York Co., Va., p. 6r, Va. State Library. readers, failing a better. But to Bishop Compton, as to others in that antique world, ecclesiastical impropriety, even when well-nigh unavoidable, was a sin more heinous than the oppression of bondsmen and unregulated morals.

Virginia had been settled when no hard-andfast line had yet been drawn between Puritan and non-Puritan churchmen, and its church cherished both, retaining down to the Revolution the partycolor of the transition period in which it was planted. Its clergy wore no surplices for more than a hundred years after the settlement, and in some parishes the eucharist was taken in a sitting posture. In New England the sacraments were hard to come by ; in some parts of Virginia they could not be refused. One Virginian, in 1645 , was threatened for refusing to go to communion in his parish church and required to bring to the next session of the court a certificate that he had reformed in this particular. In New England the baptism of babes was not always to be had for the asking; Virginians who declined baptism for their children were sometimes dealt with. 


\section{XXIV.}

In the Puritan attempt to reconstruct the Church on a scriptural model, all sorts of scruples had an opportunity to crystallize. The coupling of pastors and teachers in Paul's writings was a source of trouble and debate. The notion that the pastoral office was dual appeared in the ferments among the excited English Protestants at Frankfort before the accession of Elizabeth, it was a trait of the Dutch church life in the seventeenth century, and it was elaborated among the English Separatists before I582. In New England each church undertook to sustain two ministers in the hard conditions of pioneer life where the burden of one might have been thought too much. A ruling elder and several deacons shared authority with the "pastor" and the "teacher"; to complete the hierarchy, "ancient widows" were concluded to be church officers from their position in the Pauline epistles. This system in five tiers, originally separatist, was brought to America, in theory at least, by the Pilgrims, and, after discussion, came to be adopted by most of the Massachusetts churches. No plan could well have suited less with frontier conditions. The support of two ministers was an irksome financial burden; a double leadership promoted factions; ministers in the second generation were scarce; and the dual system, unsuited to the environment, went into swift obsolescence in spite of the lament of ideal-
Chap. IV.

Eccentricities of Church government. 


\section{The Transit of Civilization.}

CHap. IV. ists and the futile efforts of the Synod of 1679 to

Win-

throp's

Journal.

vol. i, 38,

note.

Note 32.

Scruples about psalm restore the double pastorate of the founders. The unnecessary ruling elder went out more gradually, and the proposed ecclesiastical widows were found impossible from the first, in a new country where every woman not decrepit was sure to be sought in marriage.

\section{$\mathrm{XXV}$.}

singing.

Cotton's

Singing of

Psalms a

Gospel

Ordinance.

Compare

Gospel

Musick or

the singing of David's

Psalms,

I644, with

Preface to

New England Psalm Book and

Wm.

Ames's A

Sound out of Zion

and others.

Barclay's

Inner Life, 106.

John Cotton says Satan has "mightily bestirred himself" in suggesting doubts about psalm singing. It was a question whether psalm singing was to be allowed at all. It was held that Scripture psalms were not to be sung, but only songs " indited by some personall spirituall gift of some officer or member of the church." Then there were other scruple-breeders who thought that one should sing and all the rest content themselves with saying "Amen." It was a question whether women should be suffered to sing, and it was proposed to confine vocal music to godly men regardless of their voices, not allowing "carnall men and Pagans" to join in public singing. There were other propositions of the sort, but as Cotton opposed them and attributed them to Satan, we need not drag them out of their centuries of oblivion. One that Cotton does not mention was that of the saintly Separatist and master scruple-monger, Smyth, of Amsterdam, who regarded it as "unlawful to have the book before the eye in the time of singing a psalm." The Pilgrims of Leyden, on the 
other hand, would not read the psalm line by line as sung, until at length they adopted the common mode of the time out of regard for a brother who could not read. To such extremes did anti-ritualism go. A scruple against using music books in service time caused musical notation to be forgotten almost throughout New England in the seventeenth century. The number of tunes in general use was about eight or ten, and in certain congregations but half that number. In some places the worship was without singing, failing any one who could "take the run of the tune," as the phrase was. Familiar tunes were corrupted in oral transmission; the same tune varied essentially in congregations a few miles apart; in some places the name of an old tune was all that could be recognized, the music having been "miserably tortured and twisted and quavered into a horrible medley of confused and disorderly noises." A writer of I72I declares that the music was so "dragged " that it was necessary sometimes to take breath twice in one note. Psalm singing in the other colonies was probably not better than that in New England. In the Anglican churches, as in Puritan worship, the psalm to be sung was read off line by line before the several lines were sung. One of the reforms advocated by Commissary Bray during his brief dash into Maryland in 1700 was the teaching of catechumens to sing the psalm "artificially." Even at the beginning of the Revolution Boucher declares that the psalmody was everywhere "ordinary and mean."

Chap. IV.

Note 33 . 
CHap. IV. There were not six organs in Maryland and Virginia, and there were churches in which there was no singing at all. Scruples aside, the obsolescence of music in New England was probably inevitable. But when soon after 1700 efforts were made to introduce music books into Puritan meeting-houses a sol-fa controversy arose, the conservative mind imagining that devotion itself would perish if Conn. written music displaced the barbarous discord that Valley Hist.

Society

Collections, 42.

N. E.

Chronicle, passim.

Preface to New England version of the Psalms, 1640. The so-called

"Bay

Psalm Book."

Mulcaster's Positions, 38.

The multitude of scruples. harmonized with bare and square architecture. In the preface to the New England Psalm Book the versifiers wind their logic through a sinuous argument to prove that the use of instrumental music in Jewish worship was "ceremoniall," while the psalm singing itself was "morall" and of perpetual obligation. The preface makes a merit of the roughhewn literalness of the version urging that "God's altar needs not our pollietys." Beneath this ostensible argument lay an element of all austere systems of morality, a notion that pleasure had something reprehensible about it. People opposed church music on this ground, accusing it of "bewitching the mind with syrenes sound." But colonial psalm singing could hardly be charged with such perilous seductions.

XXVI.

New England did not stop with forbidding music books; in spite of Cotton's judgment to the contrary, the Bible itself was excluded from the 
service for fear of ritualism, except where the reading was for immediate exposition. In I699, when Puritanism was fast losing its vigor, the new Brattle Street Church in Boston took the bold step of having passages from the Bible read as a part of public worship. Colman, the Brattle Street pastor, was so bold a ritualist as to repeat the Lord's Prayer after his own. Very slowly these new decencies of worship made their way. A church organ was too "ceremonial" even for the innovating Brattle Street Church, which refused a proffered gift of one. Not only must music be sung by rote and prayers not be read, but sermons must be given without notes. Warham, the first to use notes in the pulpit, was " much faulted for it." Puritanism habitually regarded religion and beauty as antagonists. Its leaders in England condemned the use of rhetorical ornaments, particularly those drawn from heathen sources. The bare hardness of expression and the absence of anything like style in early New England sermons was probably voluntary at first. Little conventional decorums, like the ring in marriage and marriage by a minister, and receiving the eucharist without gloves on, were the butt of scruples. At their first coming the New-Englanders called their places of worship churches, but here was a fine opening for scrupulosity. In order not to ascribe sacredness to a building, the merely descriptive term meeting-house was substituted, that being wholly free from any pleasant or decorous associa-

Chap. IV.

Mather's

Ratio

Discipl.,

65. Lewis's

Lynn, 106.

Turell's

Life of

Coleman,

pp. 42,178 .

Compare

Sewall's

Diary, ii,

394.

Magnalia, iii, I2I, folio ed. Nugæ Antiq., passim.

Lewis's Lynn, ro8. Sewall, iii, 279. Prince's Annals under Oct. 15, 1629 . 
Chap. IV. tion. A minister might not pray over a newmade grave; it would grow into prayer for the I Mass. dead. As there was no axe or hammer heard Hist. Soc. Col., iv, 138.

Note 34 . in the Jewish temple work, the Plymouth Pilgrims refused to take the negative in asking the assent of the church to a conclusion of the elders, and perhaps for the same reason the early Massachusetts churches formally confirmed the choice of a pastor by "silent votes" of some sort in the presence of the magistrates. Strangest of all was the scruple generally accepted at first that obliged women to wear veils during public worship. After Cotton's arrival and opposition, it was only in Salem, where Endecott was the chief upholder of the practice, that all the women went to meeting veiled, as if to deprive public worship of its last element of extraneous interest.

Minor scruples.

\section{XXVII.}

Many scruples of that age must pass unnoticed; a few others we may select for their bric-a-brac interest. The giving to children pious and significant names was not primarily a Puritan notion; Bishop Jewell has a whole page of black letter in favor of it, and he derives it from Chrysostom, the Church father. Cartwright, the Puritan leader of Elizabeth's time, also opposed the giving of pagan names to children. The scruple was too congenial to the Puritan mind not to find a place in New England, and the early Latin canons, already quoted, 
forbade the giving of "barbarous and siperstitious Chap. IV. names," and recommended those that are "ex- Note 35. pressed in sacred letters." New England accordingly blossomed, not only with Hebrew names whose frequent incongruity with Saxon surnames was not then felt, but also with nouns, verbs, and participles, such as Love, Hope, Unite, Increase, Seaborn, Preserved, Wrastle, Humility, Supply, Hopestill, Waitstill, and other significant and hortatory words, some of them given indifferently to either sex. But the practice did not take deep root, and it was one of the first peculiarities to disappear with the relaxing of Puritanism when New England life began to line up again with English traditions in the second half of the century. (The scruple against taking interest on money prevailed widely among religious people generally, and the matter was much debated, but New England seems to have escaped thralldom to a precept so illogical, In a new country where capital is lacking and opportunities for its profitable use are many, the reasonableness of an interest charge is evident, and a scruple about usury is too expensive to be afforded. Under the circumstances, the law forbidding the Jews to lend on interest to one another became ceremonial, on what ground does not appear.

Another instance of this narrow scripturism is found in the aversion to a census. In 1634 , when the population of Massachusetts was estimated at four thousand, the magistrates did not dare enu-

Winthrop's letter to Sir N. Rich. merate them on account of "David's example," and 
CHAP. IV. it is probably owing to this fear that we are without trustworthy information regarding the growth of population in the colonies. In I7I2 Hunter, Governor of New York, proposed to ignore David's example, but the fear of the people defeated his attempt to secure a census of that colony, there having been an epidemic after an earlier count. By numbering the freemen not in the militia, and adding in the already known number of militiamen, he learned the number of men. The women and children were afterward taken separately, and the inquisitive governor found means of counting, probably from tax lists, the white and Docs. rel. black bondsmen. Simple addition did the rest, and to N. Y., v, 339, 459 .

there was no pestilence. The inhabitants of New Jersey, "being generally of New England extraction, and thereby enthusiasts," as Governor Hunter Smith's said, "were more difficult to count." In a later Hist. N. Y., 302. census of New York, females above sixty years of age were omitted. This bit of chicane practiced against Omniscience allayed the pious fears of the people. New-Englanders were not the only enthusiasts on this subject. Even after the Revolution, Pennsylvanians attributed an epidemic of yellow fever to the first United States census.

The supremacy of conscience.

\section{XXVIII.}

Puritanism made one great contribution to human culture. More emphatically than any other movement of modern times, it taught the suprem- 
acy of conscience. There were instances of men who slew their natural affections in a sublime devotion to duty as they understood it. A minister felt bound to report the seditious speeches of his son, and a magistrate sentenced his own daughter to the whipping-post. Conscience could not long remain at high tide, the ebb was inevitable. The last half of the seventeenth century saw a swift declension from primitive Puritan ideals. But/through such temporary and aberrant exercises the moral nature of the race is developed $>$ by such efforts to attain a visionary and impossible excellence is the sense of right and wrong made strenuous enough to refuse the bribes of sensuality and of worldly ambition. The successors of those who exercised their consciences on frivolous judgments about apparel, psalm singing, and imaginary idolatries in the names of islands and days, may put their hereditary strenuousness or their traditional preference for ethical considerations into the promotion of substantial social betterments. The ferment may not be pleasant, but the brew is good at the last. The weakness of Puritanism was the weakness of its age. The Virginia justice, like the New England magistrate, toiled at the task of reformation by punishing with fines, and stocks, and branks, and ducking stool, and whipping-post, offenders for lying, swearing, scolding, drunkenness, and other sins. Such was the English method in the Stuart period. Neither among Puritans nor among Anglicans was Comp. Nichol's Eng. Poor Law, i, 2 rg. there any clear vision of the spiritual advantage of

CHAP. IV.

Winthrop's Journal, i, I 58 ; ii, II4.

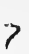




\begin{tabular}{|c|c|}
\hline CHAP. IV. & $\begin{array}{l}\text { morality. It was the outside of the cup and platter } \\
\text { that got all this rubbing. } \text { But Pharisaism is a stage } \\
\text { in human progress. More objectionable than the } \\
\text { externalism was the absence of humanity. The } \\
\text { pitiless penalties, the punishments inflicted on mere } \\
\text { children and on half-insane women for hysterical } \\
\text { words and acts, the ruthless creeds, the ferocious } \\
\text { pursuit of the weak and defenseless accused of } \\
\text { witchcraft or heresy, the unreproved delight of the } \\
\text { mob in seeing brutes torn to pieces by dogs, pro- } \\
\text { voke something like execration. But condemna- } \\
\text { tion dies upon the lips when we reflect that ages } \\
\text { to come may find many things damnable in the } \\
\text { civilization of a more modern time. }\end{array}$ \\
\hline
\end{tabular}

Note $\mathbf{I}$ page 144.

\section{Elucidations.}

Down to the Revolution class distinctions were sharply marked, especially in New York and Virginia. Compare Castiglioni, Viaggi negli Stati Uniti, passim, Pictet's Tableau des États Unis, ii, I8I, and the remarks in Virginia Calender, i, p. ix, with many other well-known authorities. The maintenance of social distinctions in the assignment of seats in church was of course English. There is an instance of elaborate classification according to the rank in the Assembly Books of the Borough of Eye in 1650, in the Tenth Report of the Royal Historical MSS. Commission, part iv, p. 534, where both the northern and southern colonial ways are exemplified. The twenty-four common councilmen of Eye sat together, as the burgesses did at Annapolis in the eighteenth century. On the effect of the aristocratic preconception in law, compare Cotton's proposed laws of I64I, where three punishments are prescribed for slander. The third is, "By stripes if the slander be gross, or odious against such persons whom a man ought to honor and cherish, whether they be his superiors or in some degree of equality with himself or his wife." Ward, who wrote the code preferred to Cotton's, did not 
like the referendum by which his code was sent to be considered Chap. IV. in the several towns. "I question," he writes, "whether it be of God to interest the inferior sort in that which should be reserved inter optimates penes quos est sancire leges." Whitmore's Introduction to Code of 1660, p. 19 . There have been in every age those who demanded justice for the lowly in the name of religion. In an Anglo-Saxon manuscript of the tenth century a bishop is enjoined not to suffer " any Christian man too greatly to injure another; nor the powerful the weak, nor the higher the lower, . . . not even his thralls, because they and those that are free are equally dear to God." Institutes Civil and Ecclesiastical, published by the Record Commission.

The notion expressed in this beginning of the Assembly's Catechism was perhaps suggested by the first question and anNote 2, swer in Calvin's Catechism:

M. Quis humanæ vitæ præcipuus est finis ?

P. Ut Deum, a quo conditi sunt homines ipsi noverint.

Compare the Select Cases of Conscience, by Shephard, of Cambridge, Mass., p. I4, and his Treatise on the Sabbath. A more moral theism than that of the Westminster Assembly was held in that time by Sir Kenelm Digby, who says, "Man is governed by God alwaies for the good of Man himself."

By the Constitution of 1638 the several plantations in Connecticut agreed to "conjoyne our selves to be one Publike State cr Comonwelth," and entered into "Combination and Confederation together, to mayntayne and presearve the liberty and the purity of the Gospell of our Lord Jesus which we now professe, as also the disciplyne of the churches which, according to the truth of the said gospell, is now practiced amoungst vs." Connecticut Records, i, 2o. On this subordination of the State compare Cotton's Abstract of Laws, iv, 4.

Cotton appeals to the favorite casuist of the Puritans, Dr. Perkins, who held that the Scripture contains a "platforme, not onely of theology, but also of other sacred sciences (as he calls them), . . . ethiks, oeconomicks, politicks, church government, prophecy, academy." It was characteristic of the age that this conclusion was not deduced from the subject-matter of the Bible, but from the fitness of things. "It is very suitable to God's all-sufficient wisdome," argues Cotton. Letter written in 1636 to Lord Say and Seal in Hutchinson's Massachusetts, i, 497. In the same letter Cotton writes: "Democracy, I do not conceyve that ever God did

Note 5 , page 147. 
CHAP. IV. ordeyne as a fitt government eyther for church or commonwealth. If the people be governors, who shall be governed ? As for monarchy and aristocracy, they are both of them clearly approoved, and directed in scripture, yet so as referreth the soveraigntie to himselfe, and setteth up Theocracy in both, as the best form of government in the commonwealth, as well as in the church."

Note 6, page 148 .

Note 7 , page 149.

Note 8 , page 153 .

About the same period Samuel Danforth, a student, afterward a well-known minister and one of the earliest mathematicians in New England, refused to recite the praises of the gods in heathen poetry, but saved the point by amending his classics as he proceeded, to the disgust of his tutor. Cotton Mather adds a marvelous ending to this anecdote, to the effect that the tutor was smitten with convulsions for reproving the lad; but we may in turn take the liberty to revise Mather before believing. Magnalia iv, c. iii, 2.

Punishment for blaspheming was derived from the mediæval codes. Antonius Matthæus the second, in his De Criminibus, published in 1644, p. 643 , says that in Holland the old rubric against blaspheming " the Mother of God, the saints or saintesses" (Moeder Gods, oft den sancten, of sanctinnen), was changed at the Reformation to a law against blasphemy of Almighty God or his holy word. But Matthæus quotes Plato's Minos that it is an indignity to the Deity to speak evil of a "man like himself" - that is, any good man.

There were those apparently who evaded the law against health drinking by merely drinking to one another. This is condemned in a Massachusetts act of September, I639, Records, i, 271. Compare the Pennsylvania law of 1682 and that of 1705 "Against Health Drinking," in which the tendency to intemperance is made the ostensible reason. See also Winthrop's Journal in various places. Practical reasons, such as the danger of excess, probably lay below all the objections to health drinking, but it was characteristic of the age that the religious reasons were sent to the fore, especialiy by the earlier objectors. In the "Great Evil of Health Drinking," published in 1684, the profaneness of the practice and its danger are both urged. Retrospective Review, xii, 322. Health drinking was thought to have been introduced into England at the time of Sir John Norris's expedition to the Netherlands - that is, after 1585 .

" Every shred of Gold drawn out of a wedge of Gold is as much Gold as the whole lumpe and wedge. Whatever is drawn 
out of the scripture by just consequence and deduction is as well the word of God as that which is an expresse Commandment." Cotton's Grounds and Ends of the Baptisme of the Children, p. 4.

Ninth Report of Royal Commission on Hist. MSS., part i, appendix, p. 1 55, Records of City of Canterbury, I 554-5: “ Rec of Rich. Orchardson, Shomaker, for openyng his wyndowes on a Sonday in servyce tyme, and for that his chymney was on fyre by nyght, and for that he was very poore he was forgevyn payment for the whole." This is said to be the first record of indictment for Sabbath breaking.

Archdeacon Hakewill says in I627 : "Common swearing, simple fornication, prophaning the Lord's Day and the like, in former times were scarce knowne to be sinnes; but being now by the light of the Gospell discovered to be such, and that in a high degree, as they are straitly forbidden by God's Law, so is the edge of our Lawes turned against them." Apologie, 466.

" Our pleasure likewise is, that the bishop of that diocesse take the like straight order with all the Puritans and Precisians within thie same, either constraining them to conform themselves, or to leave the countrey according to the lawes of the kingdome and canons of our church, and so to strike equally on both hands a gainst the contemners of our authority and adversaries of our church. And as for our good people's lawfull recreation, our pleasure likewise is, that, after the end of divine service, our good people be not disturbed, letted or discouraged from any lawful recreation, such as dancing, either men or women, archerie, for men, leaping, vaulting or any other harmless recreation, nor from having May games, Whitson ales, and Morris dances, and the setting of May-poles and other sports therewith used, so as the same be had in due and convenient time, without impediment or neglect of divine service; and that women shall have leave to carry rushes to the church for the decoring of it, according to their old custom." The King's Majesties Declaration to his Subjects concerning lawful Sports to be used.

The allusions to the early Virginia life in the text are based on the whole literature relating to colonial Virginia in print and manuscript, and the authorities are too numerous for specification. The multitude of documents of all sorts relating to Virginia life in the eighteenth century throw a strong backward light on the earlier and ruder period, but there is no lack of seventeenth
Chap. IV.

Note 10, page 155 .

Note II, page 155 .

Note 12. page 156 . page 160. 
Chap. IV.

century writings from which to make up a picture of the times. The period has usually been misapprehended. It is necessary to remember that until the last fifteen years of the seventeenth century negro slavery was an insignificant element of Virginia life. This is one of the great points of difference from the later period.

Note 14 , page 160 .

Note 15 , page $16_{3}$.

Note 16 , page 165.

The reader is referred to my tracing of this early rise of Sabbathism in The Beginners of a Nation. To the authorities there cited I here add Cranmer's Catechism, so called, which I had not seen when that work appeared. Its date is about 1548 . "And therefore that this Christian libertie maye be kepte and mainteyned, we now kepe no more the saboth on Saturday as the Jews do, but we observe the Sondaye and certayne other daies as the maistrates do iudge it convenient." This catechism was rendered from a Latin version made by Justus Jonas of a German catechism. The Lutheran catechism adds "the pastors of the churches" to the magistrates in the passage quoted above. In both catechisms these Sabbaths and holy days of human appointment are to be rather strictly devoted to religious duties and not to idleness and " ungodly works." Compare Catechism of Thomas Becon, chaplain to Cranmer, pp. 82,83 , where the ground is substantially the same.

Laxity in Sabbath keeping brought "Wrath Fires and other judgments upon a professing people," declared the Synod of 1679. There are traces of this association of fires with neglect of the Sabbath or divine worship in several places. Compare Plymouth Records, v, I77. Penhallow, writing in 1725 of the eastern Indian wars, says very ambiguously, "It is remarkably observable that among all the settlements and towns of figure and distinction, not one of them have been utterly destroyed wherever a church was gathered." Perhaps churches were rarely "gathered" in pioneer towns. Compare the "nede and povertie" anciently believed to befall Sabbath breakers, as in Cranmer's Catechism of $\mathrm{I} 548$ on the "thircle precepte," Oxford edition, 1829 , p. 43, and the corresponding Latin of Justus Jonas, I 539, in the same volume, p. 33.

During Puritan domination in Maryland a man was arrested in 1656 , the charge being " that hee shott and kild a turkey upon Sunday Contrairie to the said Act " of Assembly, but he was allowed to go free on declaring himself " sorie for his Offense." Hanson's Old Kent, 2 I 2. 
Something like the principle I have formulated, though not quite the same, may be traced in Beccaria, when in his Dei Delitti e delle Pene, he says that strong emotions, born of enthusiasm, when they become enfeebled and wasted by time, gradually become the wisdom of the age and a useful instrument in strong and expert hands. "Le passioni forti, figle del fanatismo e del en:usiasmo indebolite e rose, diro cosi, dal tempo, che riduce tutti i fenomeni fisici e morali all' equilibrio diventano, a poco a poco, la prudenza del secolo, e lo stromento utile in mano forte e dell' accorto."

Earlier than the change of evangelicalism to philanthropy came the outgrowth of a similar altruism from the enthusiasm of the early Quakers. I have reserved the treatment of this development of the reformatory spirit for a future volume of this series, in which there will be occasion to study the origins and results of Q.rakerism in examining the rise of the West Jersey and Pennsylvannia colonies.

On pp. 4 and 5 of the Practice of Piety some of the things that must be known are thus set forth for a hair-splitting generation: "In the Vnity of the Godhead there is a plurality which is not accidentall (for God is a most pure act and admits no accidents) nor essentiall (for God is one Essence only) but personall." There are pages of this ethereal verbalism. In the Select Cases of Conscience, by Shephard, of Cambridge, Mass., there is an abstruse disquisition "Of Conceiving aright of the Holy Trinity," and another "Of Ordering the thoughts aright in Civil Employments." From one on "Sinful Distractions" this example of the absence of a discriminating sense of proportion will serve: "You do not onely deserve, but are under the sentence of death and curse of God, immediately after the least hairs-breadth swarving from the Law by the smallest Sinne, and most involuntary accidentall infirmity," "the least sinne being (ex parte objecti), in respect of God against whom it is committed, as horrible and as great as the greatest." There were those who maintained that ringing chimes on Sunday was as great an offense as parricide, any sin being, in Shephard's phrase, " the dishonoring of infinite Majesty," pp. I3, I4.

The Westminster Assembly, in trying to avoid the incongruity of condemning a man for good works, takes the dilemma by both horns. "Works done by unregenerate men although for the matter of them . . . they are sinful, . . . yet their neglect

Chap. IV.

Note 17 , page $r 68$.

Note 18 , page 168 .

Note 19, page 170. 
Chap. IV.

of them is more sinful and displeasing with God." The Humble Advice of the Assembly of Divines, etc.

Note 2I, page 174 .

Cranmer's Catechism of 1548 , edition of 1829 , p. 51 , says, "If we should have heathen parents and dye without baptisme, we should be damned everlastingly." Cranmer here follows closely the Lutheran version, which reads: "Quando autem Ethnicos et impios parentes haberemus, et sine baptisme moreremur, in æternum damnaremur." The phrases of the catechism of Nowell, such as "digni æterna damnative," as applied to the unbaptized, have the inclusiveness of the church catechism, of which Nowell was probably the author. Thomas Becon, chaplain to Cranmer, in his elaborate catechism, vehemently repudiates the notion that Christian children dying without baptism are damned, but his arguments leave no room for the salvation of the infants of heathen parents. Parker Society edition, p. 22 and following. Bishop Jewell admits the possible salvation of men without the sacrament, and cites the penitent thief, but such cases he treats as exceptional. Works, I6I I, p. 26I and following. Anglican theologians in the seventeenth century generally content themselves with ascribing saving virtue to baptism, but they seem to shrink from the converse, that all children unbaptized will be damned, which was yet the general belief. Jeremy Taylor, in his Life of the Holy Jesus, section ix, discourse vi, pt. ii, 24, does not follow the " hard father of the children," Augustine, in denying salvation to unbaptized infants, but he can not escape from the prevailing ambiguity of his class. He says "well may we lament the death of poor babes" unbaptized, because if it is due to the parents' neglect " we may weep as those that have no hope." He throws the matter on God's goodness, but with much dubiety. This narrow admission of unauthorized hope made the Anglican by so much more modern and humane than such fathers as Ambrose and Augustine on the one hand, and the Calvinist divines of the time on the other. The value attached to baptism by the people is very evident. There is somewhere an anecdote of two scapegrace parsons from Virginia, who paid the expenses of a junketing tour in North Carolina by fees for baptism. Story, the Quaker preacher, in I699, heard a woman publicly reproach Lillingston, the incumbent of a Maryland parish, with having demanded a hogshead of tobacco for baptizing each of her five children. Story's Journal, 229. It was believed in Virginia that a son of a chief of the Doegs, who had been "pawewawd" or bewitched, was disenchanted and healed by the administration of 
baptism, and this miracle "was taken for a convincing proof Chap. IV. against infidelity.” T. M.’s Beginning, etc., of Bacon's Rebellion, in Force, i, 9. Traditional notions about the saving efficacy of baptism were not wholly eradicated from the minds of the first generation of New Englanders. "The people begin to complain," writes Lechford about a dozen years after Winthrop's migration, that "their children for the most part remain unbaptized: and so have little more priviledge than Heathens." Plaine Dealing, 89. The exclusion from baptism of the children of parents not in covenant with the church led to much correspondence between New England divines and Puritans in England, and tractates appeared on both sides. An Apologie of the Church in New England, . . . sent over in answer to Mr. Barnard in the year I639, I saw in the White-Kennett Library in London, and there now lies before me Church Government and Church Covenant Discussed, etc., I643. This is Richard Mather's reply to thirty-two questions sent him by ministers known to him in Lancashire and Cheshire. There is also before me a little volume dated 1643 , with a long title beginning, "A Letter of Many Ministers in Old England." It contains two letters from England and two from New England, the dates running from 1637 to 1640 . The sore question of the exclusion of many children from baptism is treated in all these publications and in others of the same period, notably Cotton's Way of Churches, 1645, and Hooker's Summe of Church Discipline, I648. While Cotton and Hooker lived, New England made no concession to the clamor of those whose children were excluded, and the United Colonies, Plymouth reserving its opinion, demanded that "Baptisme, the seale of the Covenant, be administered only" to covenant members of the churches "and their ymediate seed." Hazard State Papers, ii, 73, 74. The Cambridge Platform, adopted in I648, did not relax this proscription. But the younger generation was by this time coming to the lead, the example of Puritans in England was on the side of inclusion, and Quakers and Baptists were a little later making inroads. Puritanism in New England also felt the recoil of the Restoration in 1660 . The fifth proposition, adopted in 1662, indicates a sweeping change in policy. Of the two old leaders still surviving, Richard Mather favored the change and John Norton was temporarily absent in England. Compare the Platform of 1648 , largely the work of Norton, in Results of Three Synods (1725), pp. I-49, with the deliverance of 1662 in the same, 74-88. On certain conditions baptized persons were, after I662, 
CHap. IV. allowed to bring their children to the font. This was known as the halfway covenant. Having served its purpose for two or three generations, this "halfway covenant plan" went to pieces in the religious excitement under Whitefield and others after 1740 . Perhaps its disappearance was favored by the gradual decay of the old English notion of the indispensability of baptism to salvation.

Note 22 , page 176 .

Note 23, page 176 .

Note 24, page 176 .

"I desire if such were the will of God, and so could gladly" believe if the scriptures taught it, that all [infants] were saved." It is with these words that Robinson qualifies his acceptance of the doctrine of infant damnation. Works, iii, 233.

John Cotton, whose first thought was of the integrity of his theological system, maintained in his Grounds and Ends of the Baptisme of the Children of the Faithfull, that elect infants have faith given to them and are saved by faith. But the commoner opinion was perhaps expressed by Wigglesworth, that they were sanctified "by ways unknown to men." Day of Doom, xxv. One gets the notion that in the unwritten creed of New England the elect infants were to be found among the baptized children of the faithful. A young man of Connecticut told Story, the Quaker, that unbaptized infants were all lost, but he did not think that all baptized infants would be saved, and this was perhaps the popular feeling. Story's Journal, 308. Cotton attached so much importance to baptism that in the work cited above he expresses the opinion that a house was burned on account of the owner's honest scruples regarding infant baptism. The Confession of Dort, the most authoritative of Calvinist creeds, perhaps, declares that the children of the faithful are holy by the free benefit of the covenant in which they are included with their parents, and says that pious parents ought not to doubt concerning the salvation of their children taken away in infancy-" pii parentes de Electione et Salute suorum liberorum, quos Deus in infantia ex hac vita evocat, dubitare non debent." I Doctrinæ, caput xvii, in Sylloge Confessionum sub tempus Reformandæ Ecclesia, p. 376. This giving a kind of certainty in the case of the children of religious parents, took the place of the old dependence on baptism.

Of Wigglesworth's Day of Doom, Sibley says: “This work represented the theology of the day, and for a century, with the exception perhaps of the Bible, was more popular throughout New England than any other that can be named. It passed 
through several editions in book form, and was also printed on broadsides and hawked about the country. As late as the early part of the present (nineteenth) century many persons could repeat the whole or large portions of it." Harvard Graduates, i, 272.

Cotton Mather recounts an incident of a New England minister exhorting a criminal condemned to death to repent of Adam's sin-" the guilt of the First Sin committed by Adam was justly charged upon" him. Magnalia, book vi, p. 44, origina? edition. On this tendency of the time to give a merely legal character to sin, compare in Fuller's Good Thoughts for Bad Times, p. 277, "Imprimis, the sin of his conception."

So much of the mediaval limbo survived in New England Calvinism. Compare Wigglesworth's "the easiest room in hell" with Dante's " primo cerchio che l'abisso cigne," that circle lying round the abyss, in which are heard no lamentations save sighs that made the eternal air to palpitate, and where were a great throng "of infants, of women, and mature men," who had not sinned, but had missed of heaven for want of baptism.

\section{... e s'elli hanno mercedi,}

Non basta, perch'ei non ebber battesmo

Ch'e', porta.

This notion of baptism as "the gate" survived in the Anglican colonies, and no doubt the limbo, or "easiest room in hell," was also a popular survival elsewhere than in New England. It is noteworthy that Quakerism, having no system to complete, refused to admit the damnation of infants, or to impute "the sin of Adam to all the little children, so as to effect their Eternal State." Story's Journal, 1699, pp. 218, 219. Compare p. 308. This milder theology and the doctrine of non-resistance seem to have affected the administration of law in the Quaker colony. See Colonial Records of Pennsylvania, iii, 45, and elsewhere for instances.

The preface to the New England Psalm Book of I640 maintains that it is a moral and perpetual duty to sing every sort of David's psalms. And "the book of psalms is so compleat a system of psalms which the . . infinite wisdome hath made to suit all the conditions, necessityes, affections, etc., of men in all ages," as to "stoppe all men's mouths and mindes" from writing or singing any other psalms or hymns.

Cotton held that because the "temple should be filled with smoke" at a certain period described in the Apocalypse, there page r8o.
CHAP. IV.

Note 25 , page 177 .

Note 26 , page 177 . page 178. 
Chap. IV. could be no general conversion of the Indians. Of the apostle Eliot Sewall records this: "Mr. Eliot in his first attempt to make them [the Indians] Christian was much concerned to find out some Promise in the Scriptures relating to them. . . . But afterward he concluded that the Thirty-seventh chapter of Ezekiel was written principally for their sakes." Phenomena quædam Apocalyptica, Dedicatory Letter.

Note 29 , page 18 ז.

Note 30 , page $18 \mathrm{r}$.

In the little summary of opinions against cockfighting published in 1660 by Edmond Ellis and to be found in the Harleian Miscellany, as cited in the margin of the text, one reads, "The baiting of the bull hath its use, and therefore is commended of civil authority." Was there ever any sport so reprehensible that this defense of utility was not set up in its favor? From Perkins's Cases of Conscience, 1632, Ellis quotes: "The antipathy and cruelty, which one beast showeth to another, is the fruit of our rebellion against God, and should rather move us to mourn than to rejoice." He quotes a similar argument from Bolton's General Directions for a comfortable walking with God. From Dod and Cleaver he quotes a clirect appeal to humane feeling against cruel sports, which uses the theological argument only subordinately. "This proceedeth not of a tender heart. ... Have our sins in Adam brought such calamities upon them and shall we add unto them by cruelty in our own persons."

But the colony of East Jersey, predominantly Puritan, forbade bull baiting and cockfighting as sports "which excite people to rudeness, cruelty, looseness, and irreligion." Barber's Historical Collections of New Jersey, 36, under "Early Moral Laws," said to be for the most part extracted from a series of articles published in the Newark Daily Advertiser. The date of the act is not given, but others in the same section range from 1675 to I697. Bull baiting was probably mentioned only to guard against its introduction.

Note 3 , page 185.

Quatuor potissimum Ministerii ordines Ministrii, Doctores, Seniores, Diaconi. Nor do these words take either side of the controversy of the time on the position of apostolic teachers, whether they were ministers or not. Evidently there was a division on the question. The section concerning them is frankly inconclusive-De Doctoribus nondum visum est aliquid constituere. The Barrowist system prevailed generally, but not universally, in New England. Compare Lechford's Plaine Dealing, pp. 4 and 15, and The Temple Measured, by James Noyes, 
teacher of the church at Newbury, in New England (WhiteChap. IV. Kennett Library, West Indies, M), with various allusions in other works implying the presence of one or more churches, Presbyterian in form. The early records of the Dedham Church define church officers to be "Pastours, Teachers, rulers, Deacons, and widdowes." On the difficulty of getting widows old enough and vigorous enough, see a passage in Cotton's Way of the Churches, 1645. See also the Cambridge Platform of I648, chap. viii, sec. 7, where the duties of " ancient widows" are defined. The New England Synod of 1679 sought to restore the twofold pastorate, already hopelessly gone to decay. Question II. "Plebeian ordination" by the laying on of the hands of the people was practiced at first, but went out after the Synod of I648. Dexter's Congregationalism, 482, citing Magnalia, v. John Hull, in his Diary, 189, considers that the birth of a living male child of a woman who had joined the church, though her parents were Quakers, and whose other children had been still-born, was evidence that she "owned church order."

The system was full-fledged among Separatists in I 582 . Barclay's Inner Life of the sects of the Commonwealth cites A true Discription out of the Word of God of the visible Church. No doubt Barrow, the Separatist, who was executed at Tyburn, was the propounder of the completed scheme, though parts of it had appeared earlier among the exiles at Frankfort. John Robinson's Catechism, printed in 1642 , but of course written much earlier, elaborates this subject carefully. I am indebted to Barclay as above, p. I04, note, for this reference. On the double pastorate in Holland, see The Dutch Drawne to the Life, I664, chap. iii. What I take to be the earliest New England church constitution is the Latin paper in the State Paper Office, with Laud's indorsement dated 3 March, I634-that is, I635 N. S. The authorship, origin, and date of this paper are obscure, but internal evidence shows that its origin probably preceded the arrival of Cotton in 1633. After Cotton's ascendency began there was no general requirement that women should wear veils at public worship, as in this paper. The Latin is in places incorrect and badly spelled, and the paper could not have come from New England after such good Latinists as Norton and others arrived. In this early document ancient widows are not mentioned among the servants of the church, but they are not excluded by its phraseology.

Note 32, page 186. 
Chap. IV.

Note 33, page 187 .

Note 34, page 190.

Note 35 , page r9I.

Note 36 , page rgr.
"It is a custom generally used in most, if not in all parish churches of this kingdom, as well as among Presbyterians and others, that the Clerk alone reads aloud every verse, one after another, of the Psalm that is sung before and after the Sermon, and that all the people sing it after him." A View of the Government and Public Worship . . . in the Reformed Churches, etc., by John Durell, 1662. In New England this custom persisted generally in 1726 , though some churches by this time had books, and sang without waiting for the hymn to be " deaconed." Compare Cotton Mather's Ratio Disciplinæ, 52. Of the disappearance of the custom in the Anglican churches I can give no account.

The last two points are on the authority of the important Latin Canons and Constitutions, indorsed, as stated heretofore, 3 March, 1634 . This is no doubt the date of Laud's reception of them. The title is Canones Regiminis Ecclesiastici constituti et in reformatis Ecclesiis Novo-Anglicanus observati, breviter in ordinem digesti. I have made no attempt to control the errors in the original paper. On the silent vote the words of this document are: "Sistatur coram Magistratu et tota ecclesia, ut intra dies quatuor decim tacitis fidelium suffragis comprobetur." On the wearing of veils in meeting: "Ne quæ Mulier prœsumat sacris cœtilus adesse nisi capite Velamine tecto." See, further, Winthrop's Life and Letters, ii, ıo9, Winthrop's Journal, i, I 49 ; and Hubbard's Massachusetts, 204, 205.

"Infantibus non sunt danda nomina barbara vel superstitiosa, sed in sacris literis expressa." Latin Canons as above.

D'Ewes attributes his father's loss of property to his having been guilty of the "controversial sin" of taking interest on money. Autobiography i, 43, 44. Comp. Knight's Questio Quodlibetica, whether lawful to take use for money, 1657 , and others. 


\section{CHAPTER THE FIFTH.}

THE TRADITION OF EDUCATION.

I.

THE history of human life and institutions is inwrought of two principles running crisscross to one another. Athwart the warp of traditional conCHAP. V. Continuity of tinuity there is woven the woof of variation; the pattern changes by degrees, but the web is without break or seam. Our system of education is sometimes supposed to come from some fountain head in America, or at most to be a Protestant device dating from the Reformation. But the schools that sprang, up after the change of religion in England marked the persistence of an ancient tradition that even such an upheaval could not destroy. To find a logical point of beginning we must ascend to the early Christian centuries, when the work of religious teaching and proselytism marched abreast. Education was carried on in primitive monasteries and in cathedral chapters of a monastic type. These far-back monastic schools for teaching religion only are connected by an unbroken pedigree with our complicated modern systems of child training. We may account the ancient missionary schools a place of beginning because it would tax patience to little purpose to education.

Comp. Rept. of Royal Cath. Com., p. iv. 
Chap. V.

Early Christian schools.
Bede's

Eccl. Hist., b. iii, ch. xxvii and elsewhere.

Compare Collier's Eccl. Hist., Lathbury's ed., i, r1o, III.

grope uncertainly in the gray dawn of tradition for a connection with sources yet higher up.

II.

The instruction given in places of resort for the study of early Christian doctrine and observance seems to be whole millenniums away from the modern conception of education. There were schools or at least throngs of scholars about popular Christian teachers in England in the fifth century. Later than that the English youth even of the nobility were crossing the channel to the renowned monasteries of Ireland "for the sake of divine studies and a more continent life, ... going about from one master's cell to another," as Bede tells us. By this voyage to a foreign land these young Englishmen learned the Latin of the service book and church song, and they acquired also the elements of the wisdom of that age, such as the excellence of celibacy and the purifying effect of selfimposed hunger, which was efficient even to the sanctifying of the polluted ground on which crimes had been committed. They learned the keeping of three Lents a year, and they were taught that it was an act of superior devotion in seasons of fasting to eat daily only a little bread and milk after sunset, the milk being carefully skimmed. The proper order of singing the psalter and a method of fixing the true date of Easter were also taught, along with Note r. the doctrine of the damnation of infants unbaptized, 
and much other lore now at last happily obsolete. These early schools with their skimmed-milk asceticism at least show the human soul in insurrection against the sordidness of barbarism, but they interest us here because from them is plainly traceable across the ages for nearly fifteen hundred years the long line of a tradition and habit of education. There have been variation and evolution, but there has been no break. The monastery school became a cathedral school in some cases, and the semimonastic free school grew up alongside them both. The rudimentary school in the house of the detached priest got its impulse and direction from the higher schools in the cathedrals, and by slow changes the local priest's school became the parish school, and in prosaic modern times, by a series of transformations, the American district school, which last retains few traces of its remote ecclesias- Note 2. tical ancestry.

Chap. V.

III.

Before the Reformation the main reliance for education was on the convent schools. Young Founding of Latin women were sent to the nunneries to learn to "work and reade." Sometimes girls were given a little Latin also. Boys learned Latin in their hornbooks and other "abcees." English in black-letter characters came after. The barbarous mediæval Latin, often grotesquely macaronied with the vulgar speech, was widely used in records and account books of the time. When the monasteries were 
Chap. V.

suppressed by Henry VIII most of the higher schools went down into the abyss with the religious houses, and the English nation was faced by the ugly fact that it had pretty nearly abolished Note 3. the education of the times, such as it was.' For remedy the old cathedral schools were supplied with lay teachers, and new cathedral trusts with provisions for educating choristers and other boys for holy orders were established. Now that all the religious houses with their schools had been ingulfed, efforts were made to found free grammar schools in addition to those that had survived. Sixteen such schools were established in the time of Edward VI in as many months. But the reign of the boy king was brief; the hungry courtiers had tasted the savory spoils of the monasteries, and they grudged every morsel of it that was given to the new free schools. The reactionary rule of Mary followed, and soon after the accession of Elizabeth the Speaker of the Commons reminded the young queen of the disastrous decay of learning in her kingdom. A general zeal was aroused, not for the primary and popular education so much in favor in later times,

Positions, chap. $\mathrm{xl}$.

but for the founding of free Latin schools. Mulcaster, a schoolmaster of the time, relates that the schools established in Elizabeth's reign were more " than all the rest be that were before her time in

Harrison's Description of Britaine in Holinshed, i, 254 . the whole Realme." Another writer of 1577 says that "there are not manie corporat townes now vnder the queens dominion that hain not one Grammar Schoole at the least." The tide wave of zeal 
for founding new Latin schools reached its flood about the time that emigration to America began, and the impulse was felt in all the early colonies.

IV.

Much of the primary teaching was done at Rudimenhome. There was a great temptation to put this tary
teaching. burden on the grammar schools, and one finds many complaints in England and America regarding the disposition of parents to be rid of their little children, "whereby the usher is overburdened." Efforts were made from time to time to repel from the Latin school children who were stumbling through "the Horne Booke, the A. B. C., and the Primer." In New Haven the children who "bothered the master by spelling in English" were to be forthwith sent home. To supply the place of home An order touchinge the Free

School in Kendall, $164 \mathrm{I}$. MSS. Commisinstruction in the rudiments the dame school had grown up. This gatehouse of learning was kept sometimes by a busy housewife, sometimes by a young woman a little better taught than other women. Schoolmasters' daughters were purposely fitted to keep such schools in which the alphabet, spelling, and primary reading were taught along with the catechism, and in which girls learned to sew. "Mary goes to Mrs. Thair's to learn to Read and Knit" is a significant entry in a Boston diary. In Holland at this period there were dame schools in the care of women who were themselves unable to read, but who taught the children the catechism $\mid \begin{aligned} & \text { Huisgezin. } \\ & \text { Huin }\end{aligned}$

Sewall's Diary, I696, i, 436. Oud Hollan- 
Cнap. v. only, and that orally. Nothing so bad as this is recorded of English schools of the sort, but the dame was, no doubt, sometimes poorly qualified even to give instruction as far as the primer.

First books.

Quoted in New English Dict.

Tuer's History of the Hornbook, passion.

E. g., MS. Invoice in Mass. Archives, I6go.
V.

In the middle ages education was begun with the rudiments written probably on parchment, which was for security nailed to a wooden board, or, as an old poem puts it, "Naylyd on a brede of tre." Perhaps when paper, a much more perishable substance than parchment, came into use, the sheet thus attached to "a board of tree" was thought to require an overlay of a thin bit of horn to protect it from the destructive fumbling of the child. Such hornbooks seem to have become more common in the seventeenth century than before, and there was a disposition to make them pleasing to the eye. Both plain hornbooks and gilt ones were imported into the colonies in the seventeenth century. The hornbook contained the alphabet in capitals and in løwer-case letters, with those easy syllables in twø letters known at least in later days as the "a b abs." The alphabet had been from remote times preceded by a cross, from which the first line had come to be called the crisscross (or Christ's cross) row. The advent of Protestantism did not drive out all Catholic usages; some English children still commended their beds to "Matthew, Mark, Luke, and 
John," and in country places as late as 1618 alphabetical studies were begun at the crisscross row with the ancient prayer, or perhaps one might say charm, "Christ's cross be my spede and the Holy Ghost," "For feare the Divell should be in the letters of the Alphabet," adds the chronicler. But the first hornbooks taken to the new Puritan settlement in New England are said to have had the cross obliterated. After the hornbook came the "abce" or the "abcie," spelled also in several other ways. It comprised a series of little verses turning each on some word, which key words began with the several letters of the alphabet in succession. The device is well known in our later times. There were of old "latten abeesees" as well as English ones; the Latin were no doubt the more ancient. The primer, notwithstanding its name, was the third implement for learning put into the hands of a child. It contained at the Reformation prayers and religious meditations, but in some of its later forms it was much like a modern catechism. The primer came at last to include the contents of the hornbook and the "abcie"; such was the famous New England Primer which had its rise at the close of the seventeenth and passed through innumerable editions in the eightcenth century. The usual course was to pass the child out of the primer into the psalter-that is, to set him to reading Sternhold and Hopkins's version of the Psalms in meter. The rugged Bay Psalm Book was used as a reader in the days when don, 395.

Chap. V.

The Court and Country, 1618.

Roxburghe Libr., p. 188 .

Note 4 .

Comp. Introduction to Ford's Reprint.

Comp. Caulkin's New Lon- 
Chap. V.

approximate rhymes and a rough rhythm were the only alleviations of the child's task. But reading was also taught from little books "full of precepts of ciuilitie" done into verse "such as children will soone learne and take delight in thorow the roundnesse of the meter," as Schoolmaster Brinsley assures us. Rules of politeness in verse were centuries old in Latin, and were by this time common in English; one of these books was "The Schoole

Brinsley, passim.

Caulkin's Hist. of New London.

The grammar of Vertue," and there was a "Newe Schoole of Vertue" of French origin. To be polite, to "make his manners" by bow or courtesy to superiors, to stand reverently and modestly aside in the street when elders or people of dignity passed by, was one of the first and most important steps in early American education-it was the virtue of childhood, as it had been from the middle ages. But when the lad could read in the psalter without spelling the words, he bade adieu to school dame and English and was ready to be "entered" in Latin, as the phrase went.

\section{VI.}

By the term grammar school was meant in that day a school for beginners in Latin. One might learn some paradigms, and even more than this of Greek, in the higher grammar schools, and there were masters who added some driblets of preliminary Hebrew, the school thus including all the three learned tongues. But virtually its whole 
force was spent on Latin, which was still the CHap. v. sacred language of religion and learning. Many of the pupils in the grammar schools had to be taught their English rudiments; beyond this the Note 5 . instruction was almost whelly in Latin. Lilly's grammar, with a ponderous and forbidding title, was in that language. The difficulty of this had at length brought forth some recognized English helps for beginners, such as posing books, or, as we should say nowadays, question books, on the accidence, and there were ponies intended for surreptitious use, in the shape of helps to construe Lilly's rules; but English was ostensibly left behind. The lad must understand when the master taught him in Latin, and he was supposed to converse only in Latin during school hours. Yet in spite of "ferula" and birch switches, and the risk of being distinguished as the "asinus" or donkey of his form, the pupil still contrived to speak much to his fellows in his mother tongue. The attempt to compel conversation in Latin was not wholly successful in England, and it always failed in America, even in Harvard College. Disputation had been for centuries the favorite means of rendering scholars expert in Latin and of vitiating their general education. The taste for polemics had pervaded the universities, and even the grammar schools, from the earliest times. Lads under fifteen were set to dispute in school Latin, often "thieving" their arguments on grave questions of philosophy or intricate points of grammar, and Note 8.

Brinsley's Ludus, 215. Wigglesworth in Sibley's Harvard Graduates, i, 267 . Danker's Journal, 385. Note 7. 
Chap. V.

Brinsley's

Ludus,

passim.

In the grammar school.

mingling their disputations with boyish sarcasms and rude ridicule, in the spirit of the gamecocks, in which masters and pupils took delight.

VII.

After seven or eight years in what Milton styles "the grammatical flats and shallows," the boy left the grammar school for deeper waters. Unless he had had an unusually good master the chances were that he could read his mother tongue but stammeringly-there were pupils who at some stage of their early Latin studies lost the art of reading English entirely. The lad of fifteen or more, on leaving the grammar school, was ignorant of numbers; some boys advanced in Latin did not know the numerals, Roman or Arabic, and could not find the chapter in the Bible, "much less the verse." The boy from the grammar school had learned to write and to make his own quill pens with the point next the middle finger slightly thinner and shorter than the other, and to make a ruling pen as well, "with a nock like that of an arrow." With this he could make two parallel lines, and he ruled his own paper thus and wrote between the two lines. "Penne, inke, paper, rular, plummet, ruling pen, pen-knife," were all included Brinsley's in the outfit for learning to write, and there was Ludus Literarius, 29,47 , and elsewhere. "a blotting paper" to keep the book clean. For doing his exercises the pupil used a piece of lead thrust into a quill, and he kept a piece of new 
wheat bread at hand for use in erasing pencil Chap. V. marks. The grammar-school boy rarely had occasion to write English, and many scholars from early neglect in the grammar schools were "too backwards to their dying day" in the art of writing the vernacular. The master and his usher were often inexpert in writing; in such cases a scrivener was sometimes engaged to teach the "Roman hand" and the beautiful "secretary hand" so puzzling nowadays to unpracticed eyes. There were also traveling scriveners who taught penmanship. The lad might be weak in his English when he left school, but he made amends for it by knowing how to write themes and even verses in Latin. The producing of Latin verses was a rather wooden handicraft; the grammar scholar used his Flores Poetarum for models, and he could borrow elegant ready-made locutions from a thesaurus of poetical phrases by Bucklerius. The Sylva Synonimorum was also very handy for "schollars of iudgement." When the word in mind would not scan properly, the verse carpenter could select another with the same meaning from this Forest of Synonyms. The ambitious young poet rummaged in Textor's Epitheta after decorative adjectives; for epithets, "if they be choyse, are a singular ornament," as Master Brinsley assures us. "Descriptions by periphrases" were to be had in Holyoke's Dictionary, and there was "Master Draxe his Phrases" and other books "to see how many wayes they can vtter anything in good

Ludus Literarius, Ig6. 
Cнар. v. phrase." One Latin verse was admired because Comp. D'Ewes's Autobiog., four ways, perhaps all equally prosaic.

Writing schools.

Comp. Ciuile and vnciuile Life, p. 2 I. its nine words could be arranged in a hundred and

\section{VIII.}

A boy from the grammar school unable to write his mother tongue with any fluency and igporant of the multiplication table was not fitted for the counting house, where his dexterity in cobbling Latin verses would avail nothing. For lads destined to these employments there were English schools of various sorts, including many old-fashioned "common schools" for all classes, which debarbarized their rudimentary English by teaching youths also to "congrue Latine." When appearing alongside the free schools such were sometimes called "inferior schools" or "trivial schools." With the rising importance of trade in the seventeenth century, "writing schools," so called, came into prominence. Lads, even of good families, who showed more aptitude for money-making than for learning Latin were sent to the writing school to learn "good hands and accounts." In these Comp. schools were taught an elaborate penmanship, Willsford's Scales of Commerce, 1660 , and arithmetics of the time. arithmetic in forms somewhat fantastic, and the science of bookkeeping, complicated and intricated in that day by the multitude of varying monetary and metrical systems. Writing schools were private ventures, and in contrast to the severity practiced in the grammar school the writing school enforced 
no discipline whatever. Until the close of the seventeenth century such homely and useful schools were rarely if ever endowed. It was only by founding a Latin school that one could hope to gain the blessedness of a saint or the glory of a patriot. Such was the faith of Englishmen and of the founders of the early colonies in America. The vulgar utilities of English reading and writing. and multiplying and dividing were much more suited to pioneers in America than Lilly's Latin grammar or even than what was esteemed the "rare and almost divine matter" of "Tullies Offices." But necessary and mercenary arts could not be made objects of sentiment by enthusiastic benefactors who wrote long letters to the Virginia Company ostentatiously subscribing them "Dust and Ashes," or laid their money when they were done with it at last on the altar of the venerated dead languages for the benefit of "poor scholars" who had been traditional objects of benevolence for centuries.

IX.

Valued at first as a means of producing clergymen, we find the grammar school in the fifteenth century esteemed in Scotland as a training place for public officials "for the king's use." After the Reformation it came to be regarded in England, Scotland, and Holland as a means for propagating Protestant doctrines and eradicating heresy. But as potable gold was the universal medicine and

Chap. V. Lives of the Norths, ii, 293. Note 10. tions. Comp.
Brinsley's
Consola-
tions. Comp.
Brinsley's
Consola-
tions. Comp.
Brinsley's
Consola-
tions.

\section{)}

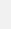

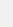

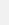

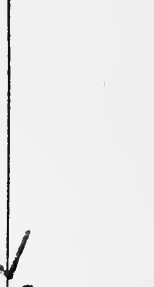
Grammar school the universal remedy. 
CHAP. V. Venice treacle the antidote to innumerable poisons, so the grammar school in that age of idealism became a cure for all heresy, heathenism, and barbarism. The greatest schoolmaster of James's reign, John Brinsley, laid at the feet of the Virginia Company the manuscript of his "Consolations for Ovr Published Grammar Schooles," intended especially for " all 1622 . ruder places, namely for Ireland, Wales, Virginia," etc., "God having ordained schooles of learning," he declares, "to be a principall meanes to reduce a barbarous people to ciuilities." It was in this spirit that the Virginia Company allotted land for a college at Henrico to bring Indian children to a saving knowledge of Christianity and Latin gram-

Brinsley's Consolations, 15 .

MS.

Records, passim.

Broadside, cited MSS. Comm., iii, 66.

Records of Company, Oct. 24, 1621. Comp. Declaration of mar. For barbarous places "so nuzled vp in rudeness and superstition" it was thought there could be no help but in a Latin school. Benefactors seeking the conversion of the "infidell's children" sent books and maps and money for the new Indian college in Virginia. This was done dramatically after the manner of the time. A mysterious well-dressed stranger appeared in the open court of the Virginia Company, depositing there a box in which were found bags of "new gold" for the education of the Indians. Passengers on a returning East Indiaman, hearing news of religious destitution in Virginia, forthwith collected money; this, with other sums, was devoted to the founding of a collegiate school at Charles City. The students were to pass out of this "East India School," as it was called, to the college at Henrico, from the 
privileges of which baptized youth were not to be quite shut out. To the endowment of the Charles City school the Virginia Company added a thousand acres of land and five apprenticed servants. The overthrow of the Company in 1624 involved the destruction of these schemes for transplanting the education then in vogue to America. Of all these benevolent projects there was a few years later not a bit of flotsam anywhere to be seen.

$\mathrm{x}$.

Benjamin Symmes, a settler in Virginia, was the first of emigrant Englishmen to bequeath an educational endowment after the pattern set by English philanthropists in the ages before him. To found a free school in Elizabeth County, Symmes, who died in 1634, gave by will two hundred and fifty acres of land with an adjacent hay marsh and a herd of eight milch cows, which by 1649 had increased to forty. Interest-bearing and profit-sharing investments were not to be had. The usufruct of land and cattle, and sometimes the income from cattle alone, had been for centuries the commonest form of bequest for benevolent, religious, or superstitious purposes. One Henry Peasley founded a Virginia free school in 1675 with a gift of six hundred acres of land, ten cows, and a brood mare. Other public-spirited people gave to Peasley's school negro slaves in place of the obsolete tenants of old English endowments and the bond servants

Chap. V. Col. of Va., 1622, pp. $5 \mathrm{I}, 53$.

Note 11 .

Symmes's and other free schools in Virginia.

Note 12.

Hening, vii, 4I. Comp. also Neill's Educational Development of Va., 26. 
Chap. V. Note 13.

Note I4.

given by the Virginia Company for educational uses. In the remaining parish records the existence of yet other free-school endowments in colonial Virginia can be traced. But the free Latin school of England was an exotic in Virginia. There was no town life, and there was small need of dispensing gratuitous Latin to thriving tobacco planters in a new country, whose clergy, such as they were, were imported ready made, and whose laymen at least did their talking and reading in mother English. The College of William and Mary did not get under way until the last years of the seventeenth century; there was no bishop on this side of the sea to induct men into holy orders; the primitive statecraft of the colony needed no other tongue than the vernacular, aided occasionally by Indian interpreters, so that the free Lating school of early Virginia was a short ladder with nothing but empty space at the top of it. Latin was studied merely as a gentleman's accomplishment. The abundant wild land, the cheap bondservant labor, and yet cheaper slave labor, which became common in the last quarter of the century, tempted the young provincial of the Chesapeake colonies to land ownership and that culture of the soil by the hands of others that had been for ages the pursuit of the gentry of the mother country. Comp. Of the character of the teaching in the few early Reports of Clergy in Perry's Collections Virginia grammar schools we know nothing. Little private schools early began to spring up at convenient points in the growing settlements which 
were stretched in a narrow, sinuous line along the margins of the watercourses and estuaries of the Chesapeake region. One may infer from the record that there were such schools before 1644 , and it appears that the cost of a year's "scoleing" at that time was equal to that of two pairs of shoes. Forty years later, in 1684 , there were so many of these little country schools that the mercenary governor, Lord Howard of Effingham, thought it worth while to exact a license fee from every schoolmaster. These schools had no relation to the parish authorities, but were established and conducted by the people spontaneously. "The children's fathers hire those schools and pay you out of their own pocket" is the quaint statement of a clergyman in a report to the Bishop of London in 1724. "To read, write, and cipher" was usually the whole course. "Care is generally taken by parents that their children be taught to read" certifies Parson Brunskill.

Chap. V. and Hugh Jones's Va., 70. MS. Records of York Co., $\mathrm{Va}$.

Beverly's Va., pt. i, 89.

Perry's Coll. Va., 268.

As above, 279.

\section{XI.}

The schools in Virginia being thus the offspring of the law of demand and supply, some of the endowed schools seem to have taught arithmetic instead of the dead languages, and one excellent education. private school in 1724 combined numbers with Latin and Greek. Virginia life in the first century after the settlement was extremely rural, not to say rustic; most of the planters had never seen a

Note 15. 
Chap. v. town, and even members of the House of BurHartwell, gesses could not conceive of life as tolerable to Chilton's

Present

State of

Va., about 1697.

people cooped up in a village where neighbors were so near that there was no range for a herd of cattle. The development of large landholdings began to produce a class of pretty rich planters in the last half of the seventeenth century who naturally wished to give their sons better advantages than they could get in the rough old field schools or the struggling free schools. Imitating the landed proprietors of England, these men brought their sons up under private tutors. The natural way to accomplish this in Virginia at that time was to buy a man trained in an English Latin school from among the redemptioners who were sold off the ship's deck for a term of years to pay their passage. This method of hiring a private tutor was in use in 1669 and probably earlier, and it seems to have prevailed in the Chesapeake region throughout the colonial period. No doubt some of the teachers who emigrated in considerable numbers in the prevalent fashion at the cost Note 16. of a temporary loss of liberty were better instructed than many of the ordinary country teachers of the time. Before 1683 the brilliant William Byrd, who was perhaps the first man born in any of the colonies with a natural gift for felicitous lit-

Capt.

Byrd's letter. Va. erary expression, had been sent to England for education. As time went on, this recurrence to Hist. Reg., the sources of learning in the Old World was frei, 64 . quent among the rich in the Southern colonies. 
In New England the Latin school found an environment distinctly more friendly than was that of the colonies to the southward. The settlers were Latin schools in New England. in the first freshness of their Utopian enthusiasm, and their church establishment was the very heart of their enterprise. In the Puritan mind preaching was really a sacrament above sacraments, though it was called "an ordinance." G®d was held tø be present "in his holy ordinances" when they had " binn setled in a way of gospel praler." It became therefore a matter of primary importance t $₫$ educate preachers. For ages preparation for the ministry had consisted mainly in acquiring a knowledge of Latin, the sacred tongue of Western Christendom. Though the Latin service was no longer used by Protestants, and the Vulgate Bible had been dethroned by the original text, and though the main stream of English theology was by this time flowing in the channel of the mother tongue, the notion that all ministers should know Latin had still some centuries of tough life in it. The first professed aim of university and secondary education in that time was to raise up ministers; to fit men for the service of the state followed close after. In all early projects for schools and colleges in America these two were somewhat grotesquely intertwined, with a notion that a first step toward converting the heathen tribes was to make some of them bachelors of art. For this purpose the en-

Mass.

Records, May, 1671. 
CHap. v. dowment of the abortive Henrico College was undertaken in Virginia, and in 1666, after no little travail, Harvard succeeded in graduating an Indian.

\section{XIII.}

Mode of $y$ The English liking for free grammar schools, grammar schools in

New

England.

New

Haven

Records, 25th of I2th month, I64I, p. 127.

re-enforced by the Puritan passion for securing "teaching elders," caused Latin schools to be set up in many places "for the better trayning vpp of youth, .... and that through God's blessing they may be fitted for publique service hereafter either in church or commonweale." The ancient Englishx cow-and-calf endowment of education, which had been already introduced into Virginia, reappears in the Northern colonies. Of the many plans trace-

New Haven and Boston Records, passim.

Tolman's Education in Rhode lsland, p. 25.

Comp. Dorchester Records, 54,55 , I645. able in early New England, it is probable that nearly all had English precedents. In New Haven, Boston, Newport, and elsewhere one finds early proposals to sustain schools by the rental or usufruct of town lands, a method used in England and incorporated in grants to early Virginia plantations. John Eliot, the apostle to the Indians, had been a grammar-school usher in England, and his parish in Roxbury appears to have contemplated a free school as early as 1642 , in which year ten shilNote 7 . lings of rental was bequeathed toward its support. In 1645 all the householders in Roxbury made a perpetual annual subscription, amounting in all to twenty pounds a year, to sustain a free school for their children, "to fitt them for publike service 
both in churche and Commonwealthe." These rentals were made a lien on " not only their houses, but also their yardes, orchards, gardenings, outhouses, and homesteads." The few resources of a new country for a fixed income were probably all tried in turn by founders of New England schools. One finds among other things the rent of a ferry, of a wharf, of a shop, of a house, and of a gristmill devoted to education. The early Virginia tenant and servant endowment finds something like a parallel in the contribution to Harvard College of a hundred and fifty pounds, apparently out of a fund produced by the sale of indigent children sent out of England as apprentices. After trying other means, deficiencies were made up in some towns by a tax rate, and this method of sustaining town schools proved the most practicable and developed after generations into the modern system. In some New England communities the school tax was levied at first on schoolable children in the several families; often the rate was shared between property and progeny. In all these expedients there appears to be a resort to methods known in England.

\section{XIV.}

The zeal for schools was somewhat more effective in New England than in the colonies farther south, because the communities were more compact and the local governments more vigorous. But it was also probably more effective, because

Chap. V.

Winthrop, ii, 264.

Mass. Records, passim. Ellis's Roxbury Town, chap. iv.

Mass. Rec., 13, Nov., 1644 . Quincy's Harvard Coll., i, 473.
The religious motive. 
Снар. v. the main body of the people was religious, and schools in the seventeenth century were a part of Note r8. the religious establishment This trait education $t$ had inherited from the ages preceding. In some way even rough and rudimentary education took on a religious color in the eyes of the people of that day. Massachusetts ordained in 1642 that every child should be taught enough "to read and understand the principles of religion \& the capitall lawes of the country." The preamble of the Massachusetts school law of 1647 makes it the motive of the act to thwart "the ould deluder Satan" by keeping the Scriptures accessible in the original tongues, that "the true Sence and meaning" might not "be clouded by false glosses of saint seeming deceivers." This law passed into the Connecticut code of 1650 , preceded by this preamble with its uncouth rhetoric; the old deluder Satan still marches at the front, followed by the Papists, the saint-seeming deceivers walking softly in the rear, "false glosses" in hand. The broad and secular uses of education were not recognized as yet.

Motive of the school law.

\section{XV.}

By this curious law of 1647 the Puritan government of Massachusetts rendered probably its greatest service to the future. The act was not modern in aim, and for a long time it was inefficient, but from that quaint act there has been slowly evolved the school system that now ob- 
tains in the United States. The rush of Puritan CHAP. V. immigration had virtually ceased about 1640 , and the attention of the New England leaders was turned toward the thronging children in the prolific families of the settlers. The religious Utopia, such as the founders had imagined when they heard the voice of the Lord calling upon them to arise and depart out of the land of their fathers, was to be realized by the children born in "these ends of the earth." As early as 1642 there was alarm at the educational decline. Before 1645 there were agitations in favor of free schools in New Haven, Dedham, Roxbury, and other towns. In 1644 the Commissioners of the United Colonies of New England bestirred themselves to collect a peck of corn from each family for Harvard College, that the supply of preachers might not fail. But the graduates of Harvard were now finding benefices in England, where, since the rise of the Puritans to power, ministers with Puritan antecedents were much sought after. In 1646 the Massachusetts General Court sadly confesses "the fewness of persons accomplished to such imployments" as required education, and looks to the future with something like consternation. Six years later the records testify that Harvard students "as soone as they are growne vpp, ready for public vse ... leave the country." Meantime "the first found-

Mass. Records, I652.

ers weare away apace." It was in the face of this disheartening exigency that the school law of I647 was adopted. 
Chap. V.

Theschool law of 1647 .

\section{XVI.}

This law, which has produced such far-reaching and unforeseen results, was confessedly a dam against the rising tide of ignorance. It was passed "that learning may not be buried in the grave of our fathers in the church and commonwealth." It ordained "that every township in this furisdiction, after the Lord hath increased them to the number of fifty householders, shall then forthwith appointe one within their towne to teach to write and to reade." This ungrammatical sentence is the vital part of the law. Towns having a hundred householders were to establish grammar schools to teach Latin, or to pay a fine to the nearest towns having such a school. This provision for Note 19. grammar schools, as the preamble implies, was intended to be the capital feature of the law, but it could not be enforced. On the other hand, the rude little schools for mere reading and writing, to be taught usually by some resident farmer, were possible in a new country, and they were realized in many townships during the next half century. Those country schools that pretended to the dignity of grammar schools were most of them shams or makeshifts to satisfy the law by such devices as covenanting that an incompetent master should teach Latin "as far as he was able," or that he should "teach English and carry them on in Latin as far as he could." Even where the teacher was fairly competent those desiring Latin came to be 
distressingly few. In the matter of rudimentary Chap. V. schools a law could not achieve much. Townships might have something less than fifty householders with perhaps a hundred and fifty children, and yet have no school. One school in a territory of six or eight miles square was but a lean provision. Considering the number of voluntary schools already in existence the first effect of the law must have been slight indeed. Popular education under its provisions was rough and scant, as the surviving documents of the succeeding age testify all unconsciously. No new kind of school was introduced by the act, and the question of support was still left with each township, "as the maior part of those that order the prudentials of the towne shall appoint." Its importance lay in the requirement by a central authority that each local community of a certain population should sustain a school in some way, and its historical value consists in the principle thus established. The outcome of this law adopted, in what was the most religious as it was the most intolerant period of New England history, has been the development of a national system of secular education for many millions of children professing nearly every creed known in the wide world.

XVII.

In human history nothing is educed from nothing; that which is exists by virtue of far-reaching roots struck deep into the mold of that which was. 
CHap. v. Pioneers especially have no time to invent; necessity rarely brings forth anything better than imitation and adaptation. What makes the school act of 1647 of consequence is the legal obligation im$J$ posed on local communities to provide opportunity for education. For this England afforded no example. But New England was quite as likely to fetch a precedent from some Presbyterian country as to follow the tradition of England. She did not need to go farther than to Scotland. At the Reformation Knox desired "to purge the Churche of God from all superstition" and to disseminate the new doctrines in the remotest corners of Scotland. 1560. In his Buke of Discipline he demanded "That everie severall churche have a schoolmaister appointed, such a one as is able at least to teach Grammar and the Latin tung, yf the Town be of any reputation. If it be upaland... then must either the Reider or the Minister take cayre over the children . . . to instruct them in their first rudimentie and especially in the catechisme." Knox proposed this system sixty-seven years before the law of 1647 ; in both we have the same Latin schools in larger towns and rudimentary teaching in obscurer places. The Synod of Dort repeated the attempt in Holland in I6r8. Knox's scheme and the Dutch imitation of it were but an expansion of the

Note 2I. parish and cathedral schools existing for centuries before. 
XVIII.

The educational decline in all the colonies was inevitable and it was universal as we may see by the extant letters, wills, and records painfully writeducation. ten by men of the second and third generations. The violent aberrations of orthography from even the rather free standards of the time, the vagrant capital letters, the halting and confused march of sentences, suggest that brains, as well as hands, were numbed by the rude toil from which pioneers may not escape. The trees of the forest were a hostile phalanx to be broken, fields beset with stumps that defied the plow were to be subdued to culture; there were savages to fight and to flee from, towns and ships to build, with tasks of Hercules beside that left small room for learning. Frontiersmen find the Latin accidence dispensable. The generations of bad spellers and clumsy writers born to a new-world battle were much better trained for their environment than the most accomplished of the first comers. They had learned from boyhood to take bearings and lay a true course through labyrinthine woods, to handle with steady sureness the heavy firelock musket or the newer snaphance, and the long-barreled fowling piece, to swing true the felling axe, and to wield the heavy beetle, to hew a puncheon floor, to build a cabin of rough logs. They could balance and paddle on salt water and fresh in wind and wild weather the tottling canoe. Patience, courage, enterprise, and 
Chap. V.

a nimble mental shiftiness could not but result from such a curriculum. But these men hardly knew more of literature than did the Greek heroes

Divers parish records of r 7 th century in original MS., Fairfax Seminary.

Printed records of several towns before I 700 .

or the Hebrew patriarchs. In the rather wellwritten manuscript records of Virginia parishes of that time "the clarkes" record that the vestry "has made choyse on" one R. M. for a church warden; that the parson has "affeciated"; that A. B. has been "opoynted overseyear" of the highways; processioning of bounds is spelled "persestioning," sufficient is "sofitiant," and so on. It is entered that a certain person has been "making his redress to this vestry for helpe." A Maryland vestry clerk had no notion of mental reservation; he records that the vestrymen took the oath of abjuration "without equivocation or governmentall reservation." In New England it is amusingly pathetic to read the records of covenants with teachers written by town clerks who doubled the $\mathrm{n}$ in English or stipulated that the pupils should learn to "rite" or "wright." The awkward pronunciation of the pioneer scribe shows through his phonetic spelling when those to be taught appear as "childeringe," and one of the three r's in a contract with a teacher is sometimes "refmetick," sometimes "retmitick." Even the Boston clerk of 1652 bewrays his speech when he writes of the "pore scollers of Hervert College." Local government has its petty side; the New England towns had "tricks and shifts to evade the school laws." Few towns escaped fine for neglect of 
school laws in those days. In some of the towns there were children that traveled long roads to school; in one case it was eight miles. In New England, as in Virginia, many children learned to read in the old English way by home instruction. In Virginia the ability to read was perhaps about as common as in England at the same period, but there are cases of a man holding local office who was obliged to make his "signum" or mark in subscribing to a document; in Andover, Mass., in 1664, five out of eleven on a coroner's jury made marks. In other colonies than Massachusetts, Connecticut, and Virginia there was yet greater illiteracy. In Maryland half the adult males were probably unable to write their names during the whole seventeenth century. Harvard College ran down in the general decline. "The greater part of the people were devoted to the Plow," as a writer of the time explains, and "learning was forced to plod out a way to live." In the last quarter of the seventeenth century Harvard was a Latin and divinity school, slim in attendance, and inefficient in teaching, while it was kicked about as a political football in the strife between the factions of the Mathers and their rivals.

Compare Quincy's Hist. Harvard, passim, and Danker's Journal, $3^{84}, 3^{85}$. Note 23.

\section{XIX.}

Through all this period of darkness and decline the colonies of Massachusetts and Connecticut, and in a less degree the other New England 
Chap. V.

governments, except Rhode Island, preserved in form and something more that which has proved an invaluable legacy for the future-a system of schools sustained in part by enforced local taxation. The school that survived "the dark ages" of New England was no longer that brought from England. Supported partly by town rates the so-called Latin school was less able even than the English school to resist the intrusion of younger children. Such pupils gave trouble at

Town Records in Livermore's Republic of New Haven, $33^{2}$.

Atwater's New Haven, I50. Harvard, and at New Haven they "bothered the master of the grammar school by learning to spell English." Yielding to the demand of supporters, grammar schools came to give more attention to writing and arithmetic. But this innovation was admitted grudgingly at first. "It is scarce known in any place to have a free school for English and writing "was the objection raised in New Haven, but even New Haven only grumbled in yielding, and so by slow degrees it came to pass that the English studies at last drove the sacred Latin from the free school founded at first for it alone. In vain did the town meeting exhort the master to "bring his boys on to latting as fast as they were capable." Latin teaching barely survived at all by the aid of such hortation and of repeated legislation, local and general. Other important changes came by the irresistible pressure of circumstances. The remoter townsmen were taxpayers also, and they tired of sending their children over weary miles of snowdrifts to the town- 
ship schools or of teaching them at home. Thus as time went on "outskirt schools" grew up. In many cases, over the whole region covered by township communities the schools were rotated so as to be kept first in one neighborhood and then in another. In the eighteenth century we find New Jersey appointing men to look after the schools, and see that they rotated properly, so that all the inhabitants might have a fair chance. By such processes the town school gradually became the modern district school. An obligation to establish and to support schools, in part at least, from the public fund having once become traditional, one finds in the eighteenth century even came schools and many writing schools maintained in part or wholly at public expense. Taking our stand at the point where the half-mediæval seventeenth gives place to the far more modern Temple's North Brookfield, 200. Judd's Hadley, 65. Boston Town Records, passim. eighteenth century, we can see that the thousandyear-old exclusive instruction of the few was in process of slow transformation into a scheme of popular and universal education. As usual in such a metamorphosis, the change was made by insensible gradations; the continuity was without apparent seam.

\section{$\mathrm{xx}$.}

No such thing as public education not dominated by religion was known in the seventeenth century. From dame school to university all was ostensibly, perhaps ostentatiously, religious. In 
CHAP. V.

such a state of society, governments freely tolerating more than one form of religious belief could do little or nothing by state initiative for education; and in communities where there was a division of sentiment voluntary co-operation in schools

Compare Bozman, ii, 99. Md. Hist. Soc. Pub., No. 9. Johnson's Old Md. Manors, p. 6.
Sollers, in Steiner's Education in Md., 16. was almost impossible. In Maryland the poor little arts of reading and writing were hardly known in some parts of the province, and it has been estimated that in the seventeenth century half of the adult males were unable to write their names. There were efforts to establish schools in the lifetime of the first generation; these were kept by one Ralphe Crouch, who was in some way connected with the Jesuits. Thirty-seven years after the first settlement the Catholic upper House of the Legislature proposed to found a government school, but the Protestant lower House promptly barricaded the way by proposing as a condition that all the teachers should be Protestants or that there should be at least one Protestant master in the school. The notion of a wholly secular and impartial rudimentary instruction had not entered the minds of men in any part of Christendom. One of those "schools for humanities" for which the Jesuit order was famous was begun "in the center of the country" in 1677 , but without aid from the Maryland government. Rhode Island was similarly embarrassed, and there is no mention of schools in the early colony records. There were schools nevertheless. The early New England system of town schools came into Rhode 
Island by induction. Bristol, in 1682 , established a school by dividing the expense between the parents of the pupils and the taxpayers, a method common in the adjacent colonies. But a retardation of educational development was the natural penalty of religious impartiality. One of the results of the English Revolution of 1688 was to make Maryland for a while a crown colony and rather intensely Protestant. In 1692 and in years following laws were passed for the promotion of "free schools" of the old Latin school kind, intended to produce candidates for holy orders who were to complete their training at the new College of William and Mary in Virginia.

CHAP, V. Johnson's Higher Ed'n in K. I., p. 2 r.

Bacon's Laws, I692-'94, xxxi ; $16 g 6$, xvii ; 1699 , $\mathrm{xvi} ; \mathrm{r} 704$, xxvii.

MS. Brit. Mus. H., II 5 .

XXI.

By comparison of such notices as we have of American schools with the English schools of School and breakfast. the period, we can form a fairly clear conception of the outward traits of school life in the age of American settlement. We may dimly see the unwilling boy "with shining morning face" and a lambskin satchel setting out for school, breakfastless, in the dark winter mornings in time to begin his studies at the unchristian hour of six o'clock. Some schools postponed the hour of beginning until seven. The session ended at eleven, when the famished pupils went home to their first meal, though in a few schools there was a recess of fifteen minutes at nine o'clock, in order that those 
CHAP. v. who lived near the school might snatch a hurried Mulcaster's Positions, chap. xl. Brinsley's Ludus Lit., passim.

Report on Burgh and Middle Class Schools in Scotland, 1867, p. I5. Knight's Colet, p. 362 .

Note 25. Note 26.

Bailey's Andover, 519.

Pennypacker's Hist. and Biog. Sketches.

Laws, Liberties, and Orders. breakfast, a meal not generally reckoned with at that time. There was a custom in earlier times of allowing the fasting pupils to take some light food in school with bottles of drink, but if the custom survived into the seventeenth century it left no trace in educational literature. The session was resumed for the afternoon when the master rapped on the doorpost at one o'clock, and it continued until "well-nigh six at night," when the scholars, who must have been stupefied by an all-day confinement, heard the welcome word of dismission, "Exeatis." In a new country the rough roads and long distances must have made it next to impossible to begin in the dark at six in the winter. By r 7 Ig the hour had fallen away in one place to "three quarters past seven." One finds the pupils of Christopher Dock, the Pennsylvania Dutch teacher, munching their "breakfast bread" along the road as they hurried to school at some unearthly time, and back-country schools in America retained cruelly long hours, with other cherished and venerable abuses brought from Europe, until the middle of the nineteenth century. In the early years of Harvard an hour was allowed at some time in the middle of the forenoon for morning bever, a light snack preceded by no breakfast. Half an hour was given to the afternoon bever, and an hour and a half each to dinner and supper. Small allowance was made for the activity of youth. There were no regular recesses for play 
in any of the schools. On occasion a great man would lend his countenance to the school by a CHAP. V. Quincy's formal visit; at such a time he might crave a little i, 517 . grace for the prisoners of learning; a half holiday was granted at his request and in honor of his advent. Such playtimes were of old called "remedyes," but austere Dean Colet would not allow to the pupils of his new foundation of St. Paul's a playday at the request of anybody less than a king

Statutes, Knight's Colet, 308. or a prelate. It was thought best to cut off this ancient privilege wholly at the little Virginia college; there were probably too many visitors of distinction; but one afternoon a month was set apart for play, and whenever a new student was enrolled "an afternoon extraordinary" was granted, "and Ludwell MSS., i, p. I. Comp. D'Ewes's Autobiog., no more."

\section{XXII.}

On a certain day in $156_{3}$, during the prevalence of "the fever pestilence" in London, there sat at Ascham and dinner in Secretary Cecil's chamber at Windsor Castle a group of distinguished men. Cecil turned the table talk to the recent flight of some lads from the neighboring school of Eton "for fear of beating," and condemned the harshness of schoolmasters. There were in the company of course some of those conservatives who rise up to defend any old-fashioned practice. But, as good luck would have it, there sat among the dignitaries of state Roger Ascham, the archery-loving, cockfighting, learned and gifted schoolmaster, who 
Chap. V: had come to Windsor that day to read in Greek with the young Queen Elizabeth one of the orations of Demosthenes. Without title or political position it is fair to suppose that he sat far down near the foot of the table; but Cecil encouraged him to speak to the question, and Ascham gave his opinion strongly and no doubt eloquently against the barbarity of schoolmasters. Dinner ended, Sir Richard Sackville, who had held his peace while the debate went on, led Ascham away to a window for private speech with him. Sackville confessed to Ascham that the beatings of a "lewde Schoolmaster" had brought him to hate learning before he was fourteen years old. He entreated the queen's schoolmaster to write out what he had just spoken at the table. By this conversation Ascham was set on writing his famous work The Scholemaster. But neither the authority of Ascham nor of any other could at once abate the unsparing severity of school discipline which was popularly believed to be eminently beneficial to boys and of scriptural authority. Thomas Becon, the reformer, had complained that schoolmasters beat their pupils "like stockfishes." Mulcaster, the successor of Ascham, had no hesitation about flogging: he speaks somewhat Note 27. gayly of "my lady birchely." Brinsley, the able and zealous advocate of school reform in the reign of James I, suggests several practical ways of avoiding brutal punishments, such as the use of rewards, and the keeping of a "black bill," or, 
as we should now say, a black list; the unlucky Chap. V. scholars set down in this list were to be deprived of their rare playtimes. But even the humane Brinsley did not once dream of sparing the rod for serious offenders; he thought "ferula" a necessary remedy for bad Latin, and he used what he calls "little ierkes" with a small switch of "red

Ludus Literarius, passim. Comp. D'Ewes, i, 63,64 . willow." When little jerks with little switches would not serve, he recommends more serious flogging; the young rebel to be held over a form or up against a post "by three or four of his fellows," making sure " to hold him fast as they are enforced to do who are to shove or tame an vnbroken colt." This was the method of a conscientious and humane master; the brutalities of the unfeeling are not pleasant to imagine. There were others than Sir Richard Sackville who cursed some "lewde schoolmaster" for a failure to get learning, and some who attributed deafness to blows received in school. "It's a general plague and complaint of the whole land," writes Peacham, "that for one discreet and able teacher you shall find twenty ignorant and carelesse." The first Brinsley's Consolations for Our Grammar Schooles, p. 43 . In Compleat Gentleman, 1660. master at Harvard went too far even for that age; it is not certain that he would have been dismissed for his barbarous punishment of students and the exceedingly short commons on which he fed them, but when he ferociously drubbed even his usher, beating him mercilessly with a hickory stick while two of his servants held the man fast, he lost his place, and set on 
Chap. V.

Quick, app. to Mulcaster, p. 300. Note 28 .

Education of girls.

Note 29.

Dedham Historical Register, Jan., I897, p. 18. Judd's Hadley, 64.

foot a reform in college discipline. A law was made limiting the punishment of students. If a student were not yet "adultus" he might get ten stripes for each offense. This was very mild; at Eton fifty-three stripes are recorded as given for a trivial fault at an earlier period, and the young John Milton had to suffer a beating from his tutor at Cambridge not very long before this. At Harvard an older student was not to be beaten at all.

\section{XXIII.}

Sometimes, though rarely, such a phrase as "male childeringe" appears in a contract with a teacher, but it was always understood that children were boys only, girls did not count. There were no girls in the schools sustained by towns or by endowment at the period of American settlement. To read her Bible and psalm-book devoutly and to use her needle deftly were the only necessary accomplishments for a woman, and these could be got in a dame school or at home. The illiterate "her mark" is signed to papers in the probate office by many women whose fathers were men of education. "Probably not one woman in a dozen could write," says a well-informed New England antiquary. In England only "the first elementarie" was taught to a girl, and Governor Winthrop was convinced that much learning was dangerous to a woman's wits. The education of the most favored girl ceased at thirteen or four- 
teen, at which age she began to assume the responsibilities of a young woman and to blossom into a waiting candidate for wifehood.

XXIV.

An English writer recommends the middle of the day for teaching writing, because the fingers would then be warmer and nimbler, which suggests schoolrooms with no fire. In New England one finds the summer school sometimes kept in "the unfinished room" of a house which is spoken of as though a room unfinished was a normal part of a new-country house. The kitchen of a dwelling, with its great fireplace, was sometimes made a schoolroom in winter, or in its stead the "parlor"; the best room reserved for weddings and funerals, on which occasions the bare floor would be neatly strewn with sand. Even where there was a schoolhouse, as at Dedham in 1658 , the schoolmaster was allowed to assemble the school in his own house "if the weather be extreme and unfit to travaill." In that climate there early grew up a custom of exacting a half cord or a "wayne load of wood for fewell" for each pupil. This was to be delivered at the schoolhouse in November, for no man of English origin in the first two or three generations after settlement knew that wood could be drawn much more easily on sleds over the snow.

Chap. V.

Traits of schools. 
CHAP. V.

College ideals.

Masson's Life of Milton, i, 197.

\section{$\mathrm{XXV}$.}

The direct influence in America of the advanced education of the seventeenth century was not great. No one with any sense of historic perspective will believe that the university men who lived or sojourned in Virginia in the early seventeenth century had any traceable relation to the group of Virginia statesmen that grew as from a congenial soil in the later eighteenth; it is equally fanciful to suppose that the existence of a considerable body of Cambridge men in early New England had anything to do with producing the literary forwardness of that region two hundred years later. But the university ideals of the time influenced directly the course of thought in the new provinces. Logic was the main study in all higher institutions, and the logic bequeathed by the schoolmen meant merely incessant practice of the art of dialectical disputation as a means of acquiring universal truth. In sermons and in conversation this verbal sword play was much affected and it rendered the wits nimble. But this highly valued "Aristotelian method" had for ages retarded the advance toward larger learning and broader views. Milton's disappointment in the university was great, and his contempt for its studies is delightfully Miltonic if not always discriminating. In his vehement complaint he ransacks "lofts of piléd thunder" for missiles with which to assail the curriculum of his time. It is "a pure trifling at grammar and sophistry," "an 
asinine feast of sow thistles and brambles"; the Chap. V. students are "mocked and deluded" "with ragged notions and babblements while they expect worthy and delightful knowledge." The universities in his opinion were "not yet well recovered from the scholastic grossness of the barbaric ages." There were university students of sound intellectual appetite, like Milton himself, who contrived to find fruit in fields set thick with the sow thistles of scholastic logic and the brambles of medireval metaphysics. Others, on being abruptly thrust at fifteen years of age into these studies, took "such a distaste of what seemed to them a mere rattle of words, that they were very slowly, if ever, reconciled."

\section{XXVI.}

In 1636 the Massachusetts General Court voted two hundred pounds toward "a schoole or colHarvard College. ledge," and the next year selected Newton, the present Cambridge, as the place for it. This proposition might have proved as futile as the early proposals for a college in Virginia had it not been that John Harvard, a minister, dying in 1638 , left a legacy for the proposed institution which thus had the breath of life breathed into it and became Harvard College. It was established on the most religious plan possible. The study of divinity was made the chief end of a student, prayer and religious consecration were prescribed academic duties; Bible reading twice a day and the faithful reporting of

\section{1}

Quincy's

History of Harvard College, i, 515, 517. 
Chap. V.

Letter of Leonard Hoar, in Mass.

Coll., vi. sermons were enjoined. The test for the first degree was a student's ability to render the Old and New Testaments out of Hebrew and Greek into Latin " and to resolve them logically." For the second degree a summary knowledge of logic, natural and moral philosophy, arithmetic, geometry, and astronomy were added. There was here a slender recognition of mathematics in advance of the English universities. The modes of study seem to have been mechanical after the manner of the time. In the earlier years of the college each student was accustomed to transcribe for himself certain treatises in manuscript on logic and other studies made by Alexander Richardson of Oxford. In examining the list of subjects for graduating theses we are now and then refreshed by the intrusion of a question that has to do with human progress; the question of the circulation of the blood was discussed in 1660 , and was again mooted in I699, more than seventy years after Harvey had announced his discovery. For the most part the themes with which college graduates in that day busied themselves are grotesquely futile as, "whether privation is the cause of anything in Nature," "whether genus exists outside of intellect," and "whether a shadow moves." Behold philosophy! It was proved at Harvard commencements by reasoners with youth and courage on their side that the starry heaven is made of fire; that there is a stone which produces gold; and that the quadrature of the circle is possible. 
The lawfulness and the possibility of curing wounds by sympathetic powder excited attention just before and after 1700 , and the existence of a universal remedy was a question equally belated in agitating scholastic minds in America. We have in these questions the everlasting mark-time of mediæval philosophy, marching ostentatiously, but never moving out of its tracks.

\section{XXVII.}

After the Restoration Virginia began to feel an alarm like that which had startled Massachusetts earlier. It is probable that the deprived churchmen who occupied Virginia parishes during the Commonwealth were now returning to England to reap the reward of their fidelity to the king. It was feared that the "want of able \& faithful Ministers" would deprive the colonists of "those great Blessings and Mercies that allwaies attend upon the Service of God," and the Assembly passed an act in $166 \mathrm{I}$, and again in 1662 , to found "a colledge and free schoole." But Sir IVilliam Berkeley, the governor, did not want either a college or a free school, and Berkeley, with a salary independent of the good will of the people, was more absolute in Virginia than his master Charles was in England. This pinchbeck Stuart detested ministers who were able to preach, and he abhorred printing presses. But the Virginia educational movement at the time of the Restoration was not

William and Mary College.

Purvis's Laws of Va., 1662 . Comp. Hening, I66I and 1662, pp. 25,56 . 
CHAP. V.

Comp.

Hening's

Statutes, ii, 3 .

I69I.

1693.

Note $3 \mathbf{I}$.

wholly without result. If the proposed subscription for the college was ever taken, it probably was not collected, and the "houseing" ordered to be erected for the college is not again heard of. But at least two bequests to found new free schools were made in Berkeley's depressing reign. After the disorders and despotisms which followed the failure of Nathaniel Bacon's bold stroke for freedom in 1676 had passed away, a college subscription was set on foot in 1688 and 1689, and sums amounting to twenty-five hundred pounds were promised by wealthy Virginians and a few English merchants. The confusion resulting from the English Revolution of 1688 probably caused delay. Two years more elapsed before the Assembly took action by ordaining an institution in three departments-a grammar school, a school of philosophy, and a school of Oriental languages and divinity. A charter was secured from the sovereigns. William and Mary, whose names the college took, gave freely out of the wild lands of the province, out of the royal revenues from tobacco, and gave outright the income from the fees for surveying land. The Virginia Assembly added an import duty on furs. In I 700 , while the building designed by Sir Christopher Wren was yet unfinished, the college at the close of its first year held a commencement. The novelty of such an exercise attracted a large concourse of people to the new town of Williamsburg. Some of the great planters came in coaches, which vehicles were yet rare enough 
in America to be noticeable. Other visitors arChap. V. rived in their own sloops, sailing in some instances from the upper waters of the Chesapeake, and in other cases on the open ocean from Pennsylvania and New York. Some even of the Indians gathered their blankets round them and strolled into the little capital to lend picturesqueness to this powwow of white men. The opening of an infant college was a notable break in the rather eventless monotony of a half-settled coast, remote from the great world.

The so-called college, thus hopefully launched, drifted inevitably into the whirlpools and eddies of petty provincial politics; its revenues were a tempting bait to the ring of predatory colonial magnates and ambitious sycophants that surrounded a royal grovernor in that day. William and Mary College was but a grammar school for years after its start, and its development was tediously slow. But most of its resources were saved from plunder and waste, and at the outbreak of the Revolution it was said to be the richest institution of learning in America-for all of which it was primarily indebted to a single man.

\section{XXVIII.}

While Scottish example, as we have conjectured, had its influence in the founding of Harvard, the influence was more direct in Virginia, where the final success of the college was due to a Scotch-

Compare Hugh Jones's Present State of Va., 1724, 83,84 .

Dr. Blair.

Charles Campbell's Hist. of Virginia, 361,362 .

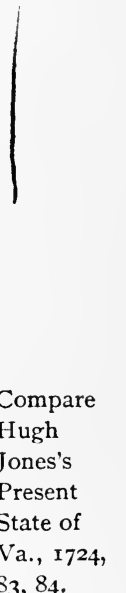


Chap. V.

Am. and W. Inds., bundle 637.

man. Behind the measures taken to advance the project by the Assembly and governor in Virginia, by the king and queen, by the Primate and the Bishop of London, by Locke the philosopher, and by the executors of Robert Boyle, there is the moving hand of James Blair, one of the most pertinacious men ever born in a land of obstinate pertinacity. Having seen the subscription well made up in Virginia, Blair went to England in 1691 with a commission from the Assembly to procure the best charter possible and a royal endowment. The traditions of the court were dead against him. The government of Charles II had made a point of discouraging in Virginia printing presses, education, and other influences that unfit people for docile submission to tyranny. The colony was to buy English wares, to swell the customs revenues by producing the heavily taxed tobacco, and to buy negroes from the Royal African Company, in which not only great courtiers but royalty itself had held shares. When Blair argued the need of a college for the sake of the souls of the people, Seymour, the attorney general, replied contemptuously, "Damn your souls, make tobacco!" A less contentious man than Blair would have given up and gone home, a man less canny and persistent must have failed. He contrived to secure William's attention in the midst of the exigent affairs of a critical time, and he managed to gain the support of both the sovereigns. His manœuvres were worthy of an expert courtier; he played Archbishop Ten- 
nison and the Bishop of London and Queen Mary Chap. V. herself with skill, and won his suit handsomely. He carried back a charter for a studium generale, a place of universal study. After his return he fought triumphantly with petty courtiers and successive governors, breaking Sir Edmund Andros himself, who had contrived to survive for many years the infamy of a great variety of disgraceful conduct in his various governments. Dr. Blair was a man of versatile ability; his printed sermons passed through several editions, and he held his place as bishop's commissary at the head of the Virginia clergy for half a century. His discipline was mild, and he fought the battles of his order against encroachments, but his clergy disliked and opposed him. He resisted the oppressions of the royal governors, but the people were never attracted to him. He had no arts of conciliation, and he had no lubricating humor. He delighted to carry a measure by mere push of pike, and to his contemporaries he was a bundle of pugnacities. Every man born north of the Tweed was an object of prejudice, and Blair was accused, moreover, of having received nothing better than a Presbyterian ordination. Though no one seems to have questioned his honesty, it was complained that he "had large worldly concerns." He lived to an advanced age, and died rich in a land where many thriftless and often dissipated parsons got on but meanly. $\mathrm{He}$ was one of the chief benefactors of a colony that never showed him, young or old, living or 
Chap. V. dead, the slightest gratitude of which there is any record. A single noble legacy made the obscure John Harvard immortal, but fifty years of resolute service and a liberal legacy to the college brought no honors to the founder of William and Mary. A good and public-spirited man, he was personally unlikable. But had Blair been less rugged, there might have been no "College Royal of William and Mary."

\section{XXIX.}

Colonies without colleges.
At the end of the seventeenth century there were efficient beginnings of higher education only in Massachusetts, Connecticut, and Virginia. New York was too much divided by the various nationalities of its people and too deeply interested in a trade reaching from Lake Ontario to the pirate settlements of Madagascar to have advanced beyond rudimentary schools. Pennsylvania and the Carolinas were too new, Maryland and Rhode Island too much subdivided in religion, and the eastward settlements of New England were too backward in development. Massachusetts had firmly established a college destined to an illustrious career, Connecticut was about to start into the new century with her Yale College, and Virginia was flushed with hope of a time when the grammar school at IVilliamsburg should grow into " a certaine place of universall study," as its charter proposed. These small beginnings were enough to mark the persistence in the Western world of the 
English tradition in favor of higher education. In communities like the expanding English-American colonies of that time, necessarily materialistic in ideals and schemes of life, the mere existence of schools whose principal studies had no value that could be balanced against tobacco and codfish, pipe staves and beaver skins-studies whose value could not be reckoned in pine-tree shillings and pieces of eight-was of high import.

\section{Elucidations.}

"In the same year of our Lord's incarnation, 664," says Bede, Note I, " a sudden pestilence ... ravaged the country far and near. . . . 'This pestilence did no less harm in the island of Ireland. Many of the nobility and of the lower ranks of the English nation were there at that time,... either for the sake of Divine studies or of a more continent life; and some of them presently devoted themselves to a monastic life, others chose rather to apply themselves to study, going about from one master's cell to another." Egbert, one of the Englishmen among the Culdees in Ireland, succeeded in escaping from the plague by vowing that he would say the whole psalter daily to the praise of God, and that he would every week fast one whole day and night. The account of his austerities in Bede, book iii, chap. xxvii, throws light on the ideals of life taught in the monasteries of the seventh century. In Tanner's Notitia Monastica he says of the Culdees: "The ancient British, Irish, and Saxon Monasteries, we find, were Schools and Universities of those times; they were not only Cells of Devotion, but also Nurseries of Learned Men for the use of the Church." To imagine anything like modern school or university instruction or learning in the monasteries of that early age would be misleading. In the Catholic monasteries and cathedral establishments organization was perhaps more perfect than among the Culdees. We get a view of higher and lower instruction as already established in a canon of A. D. 747, number 7 , in Johnson's Ecclesiastical Laws. Some curious traits of the schools in the houses of the priests may be deduced from the canons in the

Schools before the Reformation. 
same work under A. D 960, numbers IO, I I, 5 I, and A. D. 994, numbers 19 and 20. "When the Monks were rooted out by the Danish wars," says Tanner, “ an universal ignorance overspread the land, insomuch that there was scarce any one in England that could read or write Latin. But when, by the care of King Edgar and Archbishop Dunstan, Monasteries were restored, Learning found its former encouragement." Preface to Notitia Monastica. Fitzstephen relates that there were famous schools in three principal churches of London in the twelfth century. Furnivall cites a saying of Roger Bacon that there were schools in every city, town, burgh, and castle in the thirteenth century. Compare also Wright's Domestic Manners and Sentiments in the Middle Ages, $33^{8}$ and $\mathrm{ff}$. There is evidence of the survival of the teaching of children by the mass priest in the action of the corporation of Bridgenorth. When a more modern "Comyn Scole" was substituted at the beginning of the sixteenth century, a by-law was adopted which ordained that "there schall no priste kepe no scole save oonly oon child to helpe hym to sey masse." MSS. Commission, $x$, part iv, 425. There is an instance as late as Mary's reign of the restoration of an ancient endowment by town lands for the support of a priest " Habill to teache Grammar." Ibid., 533. In Collier's Ecclesiastical History, part ii, book iii, I65 (Lathbury's edition, vol. v, 29), we read: “'The abbeys were very serviceable places for the education of young people; every convent had one person or more assigned for this business. Thus the children of the neighborhood were taught [Latin] grammar and music without any charge to their parents: and in the nunneries those of the other sex learned to work and read English, with some advances into Latin." Stow, in his Survey of London, notes that the Lateran Council in I 176 recognized cathedral schools, but in the Capitularies of Theodolf they are carried back to the end of the eighth century, and were, beyond doubt, still older. Johnson's Ecclesiastical Laws, 994, 19. Down to the end of the tenth century almost the only seminaries in Charlemagne's dominions appear to have been in cathedrals and convents. First Report of Cathedral Commission, xxv. It is to be noted that many of the English cathedrals were monastic institutions; in eight out of seventeen in the twelfth century the chapters were composed entirely of monks. Collier's Ecclesiastical History, book iv, cent. xii, 34 I (vol. ii, 232, of Lathbury). On the origin of cathedrals and the colleges in the early Episcopia, see Report of Cathedral Commission, p. iv. 
Schotel, in his Oud Hollandsch Huisgezin der Zeventiende ChaP. V. Eeuw, p. 75, says of education in Holland: "In the earliest time most of the parish churches had their schools. . . The school of the cathedral church [hoofdkerk] took the name of the great school. . . . In these last were taught not only Greek and Latin, but Dutch-that is, reading, writing, and ciphering, and not alone to the children of the well-to-do, but to the poor as well. They were all comrades in the school as in the street." Roger's Work and Wages, 165, I66, remarks on the widely diffused knowledge of Latin in the middle ages. Until the fourteenth century English was not even suffered to play tender to Latin in the schools, but in 1363 "it was ordeined that schoolemasters should teach their scholers to construe their lessons in English $\&$ not in French, as before they had beene vsed." Holinshed, ii, 678. Down to the Reformation Latin was taught before the reading of English, as we learn from Mulcaster, an Elizabethan schoolmaster. "Now," he adds, "we are returned home to cur English abce." Positions, chap. v.

A definite number of scholars were to be sustained in each cathedral while living in commons. Whiston's Cathedral Trusts and Harrison's Description of Britaine, i, 235. The First CatheIral Report, p. xxiv, cites Cranmers Reformatio Legum that every cathedral should maintain a school for the mature education of youth. Chantry priests, whose support came from endowments for prayers for the dead, found their occupation gone when the government had forbidden all praying for the dead, and had indeed abolished purgatory. It was therefore ordained that such priests should "exercise themselves in teaching youth to read and write and bring them up in good manners and vertuous exercises." Bills were brought into Parliament in Edward VI's reign "for incouraging men to give lands for the maintenance of schools." Tanner's Notitia Monastica, preface, citing MS. authority.

By suppressing the alien priories, which were but offshoots of foreign monasteries, Henry $\mathrm{V}$ made a tempting precedent for Henry VIII, but Henry VI supplied the place of the schools lost with the suppressed priories in the preceding reign by founding various free schools in I 393 and I 394. See the section on Schooles and Houses of Learning in Stow's Survey of London, and Collier's treatment of this period in his Ecclesiastical History. Dean Colet's foundation of St. Pauls School in 1512 was " in place of an old ruined house," says Stow, and Christ's Hospital, in 1553,

Note 2, page 209.

Note 3, page 2 Io. 
Chap. V.

was planted in the "late dissolved house of the Grey Friars," and " a school was ordained there." Many of the new free schools of the Reformation period were endowed out of the spoils of the monasteries. "For the most part the endowments were out of the tithes formerly belonging to the religious houses or out of chantry lands given to the king in the first of his reign, according to the intent of parliament therein, which was to convert them from superstitious uses into more godly, as in erecting great schools for the education of youth in virtue and godliness." Strype's Memorials (1822), vii, part ii, pp. 50, 51. Thomas Williarns, Speaker of the House of Commons, in 1562 " took notice of the Want of Schools; that at least an Hundred were wanting in England which before his time had been." In giving this passage Strype adds, "being destroyed (I suppose he meant) by the Dissolution of Monasteries and Religious Houses." Annals of the Reformation, i, 292. The demand for Latin schools was no doubt increased by the growing ambition of the people in the new social conditions. No means were so convenient "to make Jack a gentleman " as to send him to the university to win the coveted title of "Mr." Even cobblers sought education for their sons. Hall's Satires, iv, II ; Howell's Letters, 405, 406. Mulcaster thought that every child should learn to read English and also to write for his "necessary dealings." Positions, chap. 36. He refuses Latin to the common people because of the prevailing ambition to rise in England, but he adds significantly that "both clownes in the countrie and artificers in townes be allowed lattine in well gouerned states, who yet rest in their callings." "Factors or Marchants and the like, going beyond seas find it necessary and convenient to speak Latin," says Brinsley, Ludus Literarius, 2 II .

Note 4 , page 213.
There was published in 1538 an A B C book, and it has been reprinted. The editor writes a preface wherein he says the Ten Commandments are not included. But they are included in rhyme-rhyme was the only amelioration of reading in that day. This is the authorized primer of 1538 , though the editor says it is not. It has the A B C and the " a b abs," the Lord's Prayer in Latin and English, the Hail Mary in both tongues, and the Creed in both. Then there are parts of songs in Latin, " to help a priest to sing "- that is, for the child to help him to sing. This is followed, wholly in English, by an extended grace before and grace after "dyner." Then there is a grace for " fysshe dayes " and grace after dinner, and a short grace to be said be- 
fore dinner and another to be said before "dyner" or " souper," a short grace after dinner and another after dinner or supper, then two graces after supper, then an Easter grace before and after dinner, then a prayer, then the Ten Commandments in rhyme, and then a series of rhyming precepts. The great number of graces before and after meat came from the habit of having children say grace. There were no breakfasts in Henry VIII's time, and no graces for such a meal.

One may be permitted to doubt the unbroken continuity of the master's Latin in many cases. The language in which the celebrated Harvey lectured to medical students on the circulation of the blood was probably better Latin than an ordinary schoolmaster's, but it is intentionally mottled throughout with English. Take this phrase for one example of a thousand: "Exempto corde frogg scipp eele crawle dogg ambulat." Prelectiones, 7. But Bacon says that pupils are to make paper books and to note the best sentences of the Roman tongue, and practice them in speaking and writing.

I have referred in the margin to Wigglesworth's complaint of the "boldness to transgress the college law in speaking English." Brinsley laments the remissness of his time in teaching English. Some colleges in the English universities made the constant use of Latin obligatory (Brinsley's Ludus, 2II), but in all lectures and exercises were in Latin. Harvard students were quite unable to speak Latin when Dankers met them in 1689 . It may safely be said that the colloquial use of Latin never found a lodgment in America.

Brinsley had " laboured and striven by Ferula and all meanes of severity" to improve the Latin of his boys, but he says, "I have not been able to make Schollers to vtter their mindes in any tollerable manner of ordinary things," etc., " without great severity." He confesses " they will not be brought to give overspeaking English." Ludus Literarius, 215. Theoretically, students admitted to Harvard could all speak Latin, but the requirements for admission were probably not strictly exacted. "When any scholar is able to read Tully or such like classical Latin author extempore, and to make and speak true Latin in verse and prose Suo (ut aiunt) Marte, and decline perfectly the paradigms of nouns and verbs in the Greek tongue, then may he be admitted into the college." Laws, etc., of Harvard, 1642-1646. Quincy's Harvard College, i, 515. Note 7 , page 215. Note 8 , page 215 .

Chap. V.

Note 5 , page 215 .

Note 6, page 215 . Page 
Chap. V.

Note 9, page 217.
The rage for disputation in the schools had been even greater in earlier times before logic had been mainly relegated to the universities. Fitzstephen says in the twelfth century that upon holy days assemblies gather in the churches to hear these disputaitons of scholars, in which all the technical forms of reasoning and rhetoric taught by the schoolmen are practiced for display, and boys of the different schools "wrangle together in the art of versifying, and canvase the principles of Grammar." Stow's Survey, 705, with his quaint translation, 710, 799, edition 1633 . In the sixteenth century this had been done away with, but Stow himself had seen assemblies of boys from various schools gathered in a churchyard to dispute on an improvised platform about the principles of grammar for the fun of the thing. As above, 64 . When these gatherings ceased the boys from the rival schools of St. Pauls and St. Anthonys would provoke one another in the open street with the challenge to debate "Salve tu quoque, placet tibi mecum disputare?" To which the reply "Placet" being given, they fell to wrangling over tenses and constructions until often there ensued a general scrimmage of the two parties laden with satchels of books and piling themselves on one another in heaps to the obstruction of the streets.

The usher who was ultimately to be master of the free school at Charles City, Va., was apparently incompetent to teach writing and arithmetic. The Company gave him permission to take with him "an expert writer," who should be able to teach "the grounds of arithmetic, whereby to instruct the children in matters of account." But no other provision was made for such a man than to give him his passage free, leaving him to be paid by the parents. Abstract of Records, ii, 167. The form proposed for the organization of the school at Charles City, Va., was identical with that carried out in the grammar school of William and Mary College, nearly a hundred years later. There was in both a master, an usher, and a writing master. Compare Ingle's Letter, I705, in Historical Collections relating to the Colonial Church, Virginia, I40. See the statute regulating the mendicancy of scholars of the university in 1388. Statutes at Large, ii, 302. Students appear to have continued to beg until forbidden by the statute of 1572 in the reign of Elizabeth. Compare also Jusseraud's English Wayfaring Life, 232, 233, and Wright's Domestic Manners, 339. The "poor scholars" were still made prominent in early appeals for Harvard College, and one is tempted to suspect, from the prominence given to Indian education at Harvard 
and in the early Virginia projects, that the "infidel " was substituted in part for the poor scholar as a means of stimulating liberality. A kind of mixed school, in which plebeian arithmetic jostled Latin grammar, existed in England and appeared early in America. For example, Dedham Records for 1663,1670 , iv, 67, 133 . Bailey's Andover, 517. Compare p. 520 of Bailey, where there is a sort of confession that English studies are intruders in a Latin school, for a schoolmaster in 1723 is specifically bound as an additional duty " that he wold Teach boys to Read, Rite, and Cypher." Comp. MSS. Commission X, part iv, I38-I40, where in 1695 a so-called writing school endowed by Sir John Moore is expected to fit boys for the university.

The old conception of education is struggling with the new. (Of old higher education was the property of the few. In 1559 one of the measures suggested to Parliament was that the study of the laws, temporal or civil, be restricted to the sons of noblemen or gentlemen. Seven years later Knox sought to teach everybody their " first rudimentie" in order to render them Protestant. In I6I6 the Synod of Dort tried to teach the catechism to all for purposes of religious indoctrination. In 1622 we find Brinsley struggling blindly with the principles of education, " God having ordained schooles of learning to be a principall meanes to reduce a barbarous people to ciuilities." It was just twenty-five years later that Massachusetts proposed to confound " the ould deluder Satan" by schools especially in Latin and Greek and Hebrew, but English schools were finally almost the only outcome of the act, the practical sense of the people gradually doing away with the superannuated Latin school. Of course, the clergy were educated in Latin. Justus Forward, of Belchertown, Mass., so late as 1763 , writes D. D. (dies dominica) for Sunday, and several other days appear in their Latin dress. He says "studiebam" and "occupatus studiendo," "occupatus de iisdem," and "Daniel dragged ibidem," in his English diary. MS. in my possession.

The first Virginia Assembly, in 1619, petitioned in favor of the erection of a proposed " university and college." New York Historical Collections, iii, i, 342. The Company, with wise forethought, reserved liberal tracts of land for the support of churches and a local school in each plantation. Smith of Nibley MSS., New York Public Library. In Fuller's Worthies, i, 566, 567, it is said that Edward Palmer (whom Camden, in his Britannia, I6ro,

Chap. V.

Note ro, page 219. 
Chap. V.

folio 366 , calls " a curious and diligent antiquarie," and who died in 1625) purchased an island in Virginia, called "Palmer's Island unto this day," and that he spent several thousand pounds in a fruitless endeavor to plant an academy upon it. Neill, in his Virginia Vetusta, says that the island in question was at the mouth of the Susquehanna, and gives for authority the Hermans-Faithorne map. I had the unique copy of this map in the British Museum examined, and received this report: "There is no island marked Palmer's Island on the map indicated at the embouchure of the Susquehanna or at any other point. There are marks of islands, but no name attached." That the island at the mouth of the Susquehanna was called Palmer's Island is to be deduced from the Proceedings of the Council in Maryland Archives, where an observation of its longitude is recorded in 1683 . It was a wild and solitary place for a school.

Note 12 , page $22 \mathrm{I}$.

Note 13 , page 222 .

Note 14, page 222 .

In 1467 a testator left a cow to keep wax candles burning before the image of the Virgin in Felsham Church. In I 530 two cows were bequeathed " to the sepulchre light in Ampton Church to continew for evyr." In such cases the increase of the kine went to make the bequest perpetual. Bury wills, Camden Society, pp. 44 and 249. Dr. Fuller, the physician of the Pilgrims, gave "the first cow calf that my brown cow shall have to the church of God at Plymouth," and a ewe lamb was a common bequest to that church. Brigham, in Lowell Institute Lectures, I74, 175 .

In the manuscript records of Christ Church parish, Middlesex County, Va., I find allusion to a free school already existing, for the benefit of which two cows have been bequeathed in 1691 . As early as 1655 four cows were left in Isle of Wight County for maintaining and schooling orphans. In I669 King Free School, in the same county, was established by bequest, and some other endowments can be traced, while there were those probably of which no record has been found. See two papers on this subject in the William and Mary Quarterly for 1897.

The boast of Sir William Berkeley, in $167 \mathrm{I}$, that there were no free schools in Virginia-Hening, ii, $5 \mathrm{I}$ I and ff., and Virginia Historical Register, iii, 12-has been repeated by superficial writers on the period. Berkeley adds, "Learning has brought disobedience and heresy and sects into the world." The passage is but a vivacious revelation of the state of mind of a willful and avaricious dotard, in whom contempt for the popular rights and the 
wishes of the people was hardening into that brutality which Chap. V. made his last years so terrible for Virginia, and brought about his own ignominious downfall. In $167 \mathrm{I}$, when Berkeley wrote, the Symmes free school was in existence, the Eaton school was founded before 1646 probably, the King Free School endowment was made two years before, and four years later Peasley's liberal bequest was given for another free school. Both the Symmes and Eaton schools were in existence more than a century after their planting. An act had been passed in $166 \mathrm{I}$ for the founding of a college which involved a free school. Berkeley probably krew better than any other person why the project slumbered. Se:e section $x x v$ of the present chapter. But the English system of free schools did not and could not obtain to any considerable extent in Virginia in $167 \mathrm{I}$ or even later; physical and social conditions were against it. Compare Foote's Virginia, i, I I. In colony times the only Virginia school that rose to the dignity of the English free schools was the one attached to William and Mary College. Compare the inhibitions of printing in Virginia in I 682, Virginia Historical Register, iii, I3, and the utter prohibition of printing presses in Effingham's instructions of 1685 . The allusions to schools in the seventeenth century that can be picked up from the remaining local records of Virginia are not many, but by comparing them with Beverley's statement of Effingham's course in licensing teachers about 1684 , and then examining the replies of the Virginia clergy in 1724 to the Queries of the Bishop of London, we can form some notion of the voluntary education by means of "old field schools" that early grew up among the Virginians. As the bishop's query asks only about parish schools, some of the replies give negative information; but wherever the clergyman mentions the rustic schools they seem to be fairly numerous for a new country, to be taught by men and not women, and not to be above the level of the rough country school of the period elsewhere. “In most parishes," says Hugh Jones, "are schools in Little Houses built on purpose, where are taught English and writing." One private school for Latin and Greek flourishes in the same parish with two endowed schools of a lower grade. In one case a plantation was given to the incumbent of the parish on condition that he should sustain "a sufficient person" to teach reading, writing, and arithmetic. In Maryland, the ideal of Bray was a free school in every county, and one or two in the province for Indians. This does not account for the little schools. General View of the Colonies, prefixed to sermon of 1697, p. 7. 
Chap. V.

Note 15 , page 223.

Note 16 , page 224.

Note 17 , page 226 .

Note 18 , page 228 .
In Ciuile and Vnciuile Life, 1579, 1586, Roxburghe edition, p. 21 , the country gentleman is made to say, "Wee gentlemen in the Country, vnlesse our sonnes proceed in the study of the common lawes, Diunitie, or Phisicke, doo hold them learned ynough if they can write and read English, and congrue Latine." Note that he must "congrue Latine" - that is, after a fashion put it together. This probably represents the education thought fit for his son by the Virginia planter a hundred years later. Even so much Latin probably could not always be had.

There were some convicts who were capable of teaching, but the convicts were not usually of the kind to supply teachers, and in Virginia in the seventeenth century there were fewer of these than of indentured servants known as "free-willers" who had embarked of their own accord, and the "kids" who had been " trapanned " aboard ship by craft or force. The schoolmasters no doubt usually belonged to the class of voluntary or involuntary redemptioners, and not among the petty criminals who were sold for seven years. The will of Colonel John Carter, in 1669, specifically provides for the purchase of a bond servant who had been "brought up in the Latin school," to teach his son Robert, afterward the famous King Carter of Virginia. See quotations from the records at Lancaster Court House in a letter from Mr. Wilson Miles Cary in The Nation of April 22, 1897. Boucher long afterward says that two thirds of the schools in Maryland were taught either by indentured servants or by convicts. Causes, 184, I89. I think the convicts much the smaller of the two classes. Boucher would have mentioned the fact had it been the other way.

The general responsibility of a corporate town as such for the support of its school, where there was one, was a trait of English life, carried over to the rustic municipalities or "towns" of New England, and gradually changed to our more local system. Compare, for example, what Brinsley says in 1622 in speaking of badly managed schools: "That it were better to turne the maintenance given to the schoole to bear the charges of the towne for other duties and seruices then so vnprofitably to employ it." Consolations for Our Grammar Schooles, 43.

The rough life of the frontier has always been dangerous to morals and manners. The remedy proposed in Massachusetts was rather traditional than practical. It was ordained in 1642 that children when tending cattle were to employ their time at spinning on the rock or distaff and knitting tape, and boys and 
girs were forbidden to converse together. Such an order was Cinap. V. doubtless without any result. In 1645, after the news of the great Virginia massacre had startled New England, boys were orclered to learn the use of small guns, half pikes, and bows and arrows, thus reviving old English customs and customs as old as the Roman law, no longer of any value. Compare Ridley's View of the Law, 1634, p. 48.

In President Chauncy's Commencement Sermon of 1655, p. Note 19, 38. what may be called the unattainable ideal of the tinie is page 23 . thus expressed: "In cittyes and greater towns schools should teach the Latin and Greek tongues, and Hebrew also, which ought to be had in great account with us for the Old Testament sake."

In the platform of Church Discipline adopted in 1648 , vi, 6 , the school is regarded as "lawful, profitable, \& necessary for training of such in good Literature or Learning as may afterward be: called forth unto office of Pastor or Teacher in the Church." This hesitating indorsement of the school is backed up by half a dozen texts of Scripture. In re-enacting the school law the Connecticut General Court of 1673 omitted the epithet "old deluder" before Satan, whose character was well enough known by this time, and in 1692 the diabolical preamble clisappeared entirely from the laws of Massachusetts. Compare also the New Hampshire law of 1715 . In 1673 Connecticut made it obligatory on county towns to have a grammar school, "for the use of the county," under penalty (after I677) of ten pounds. In I678 Connecticut took the lead of Massachusetts by making it obligatory on every town of thirty families to have an English school. In $168+$ the surplus money of the treasury was to go to the grammar schools. All this legislation testifies to the increasing difficulty of maintaining the so-called Latin school. Massachusetts in 167 I increased the fine for neglecting schools to ten pounds, and ordered it paid to the nearest town having a grammar school. To cite no other evidence of the struggle to keep alive grammar schools, the New Hampshire law of $\mathbf{5} 7 \mathbf{2 1}$, in something like desperation, makes the failure for a single month on the part of a town of one hundred families to provide a Latin school punishable by a fine of twenty pounds, to be collected from the personal estate of the selectmen. This was no doubt in depreciated currency. See Weeden's Economic History of New England on the decline, and in some cases the extinction, of New England Schools. 
Chap. V.

Note 2I, page 232 .

From the Third Report for the Commissioners on Education in Scotland for I 867-'68 we learn that schools for Latin, to which were subsequently added " Lecture" schools for English, existed in the chief towns from a very early period. Several of these schools are known to date from the twelfth century. All the chief towns had schools before the beginning of the sixteenth century. "The statute of James IV (I496), which ordains that barons and freeholders who were of substance should put their eldest sons and heirs to the 'scholes fra they be six or nine year of age, and to remain at the Grammar Schools quill they be competentlie founded and have perfite Latine,' is conclusive on this point." These schools were closely connected with the cathedrals, monasteries, and religious establishments ; the teachers were ecclesiastics "or in some way connected with the cathedrals and monasteries," and they were sometimes sustained by altarages. "The scholars . . . were no doubt originally those destined for the church. Gradually, however, sons of gentry and of barons . . . were sent . . . to these schools, and from the beginning of the second or more flourishing period of the history all the higher middle classes took advantage of them." It is interesting to find that not only the grammar but the elementary schools existed in Scotland in I494. In that year the chancellor of the diocese of Glasgow orders that no one without his license should teach "scholares in grammatica aut juvenes in puerilibus." Light is thrown on the condition of Scottish schools just before the Reformation by Andrew Melville's account in McCrie's Life of Knox, 475, 476. The repeated legislation in $1616,1633,1646$, and finally in 1696 , shows how slowly the plan was put in force. Report of Commissioners, p. 8. It is worth remarking as illustrating the force of historic continuity, even in time of revolution, that Knox's reader or minister teaching the rudiments in an "upaland " town is only a Protestant reproduction of the older priest in small parishes combining teaching with "praying for the people," such as we have already mentioned above as existing in former ages in England. It would carry us too far afield to note here the rather futile efforts made in the seventeenth century to make Knox's ideal actual in Scotland, or to discuss the Scotch school establishment of 1696 , etc. It is sufficient that the plan set forth in 1560 remained a fixed ideal and tradition in Scotland, as the plan of 1647 did in New England. In 1704 most of the parishes in Scotland had each a Latin school in name, but the masters were nearly all incompetent. The schools were not free, but, as in many New England 
towns, the fees of the scholars eked out the teacher's living. Proposals, etc., in Harleian Miscellany, Park's edition, i, 500 and ff. Some towns, as Polworth in 1652 , had no salary for the teacher except his "quarter payments" from the pupils. MSS. Commission, xiv, App. iii, p. 94. Comp. p. 128. As in Scotland, so in Holland, the reformed clergy early sought to strengthen their position by means of schools and a system of catechetical instruction. The plan proposed by the Synod of Dort in 1618, probably with a purpose of extirpating Arminianism as well as Romanism, was to establish schools for teaching "Christian doctrine" " in towns and country places where none have existed." In these schools the children of the poor were to be gratuitously instructed by orthodox teachers, well versed in the catechism. Two whole days in the week were to be given up to teaching the catechism. The resolutions are translated in De Witt's Historical Sketch of the Parochial School System of Holland preceding Dunshee's History of the Dutch Church School in New York. Of the state of the schools of Holland in the seventeenth century a notion may be formed from Schotel's Oud Hollandsch Huisgezin, Hoofdstuk, $\mathrm{x}$, from which I have quoted in a preceding note. Compare also a brief summary in English of Schotel's chapter in Geddes's History of the Administration of John De Witt, 33-37. Some of the mistresses of Dutch bye schools or shop schools (byscholen, winkelscholen) could not read, but taught the catechism orally, and the school teaching was generally of a primitive sort. But the Synod of Dort had made a declaration resembling that of Knox in favor of schools in every parish, and this unattained Dutch ideal would be likely to have weight also in New England. Rude and imperfect as was the system launched by the Massachusetts law of $\mathrm{I} 647$, it made "writeing and reading," not the catechism, as in Holland, the corner stone of the country school.

A letter written by Governor Dudley to the Society for the Propagation of the Gospel in r7or says of Massachusetts, Connecticut, New Hampshire, and Maine, “I am of opinion that there are no children to be found ten years old who do not read well, nor men of twenty that do not write tolerably." Such a condition probably has never existed among the people of so large a region in any part of America from the Glacial epoch to the present time, and, considering the character of the astute politician who expressed this opinion, one should not take it too seriously. It is said by Upham, the industrious historian of Salem, that very

Chap. V. 
Cinap. V.

many people could not read in the ancient capital only nine years earlier, and that schools were in a bad condition.

Note 23, page 235 .

Note 24, page 237 .

In the Blue Book for 1867 the Report on Burgh and Middle Class Schools in Scotland, from which I have already quoted, referring to the Buke of Discipline, says that by the colleges which Knox proposed for every notable town he intended "grammar schools on the model of those more ancient seminaries in which the "trivium ' or course of three sciences were taught," p. 5. A passage in the same report on p. 7 suggests the source of John Harvard's inspiration: "Cambuslang, where the Rev. John Harrison, minister of the parish, endowed a Grammar School in I602; with Prestonpans, where a trilingual school for the teaching of Latin, Greek, and Hebrew was founded about the same time by the Rev. John Davidson, who endowed it with all his fortune, including his books." That it was early found difficult to exact Hebrew of the Harvard students is apparent from the extracts from Wigglesworth's diary in 1653, given in Sibley's Harvard Graduates, vol. i, under the name of the diarist.

A multitude of illustrations might be cited. "That ye education of youth may be carried on sutably to Christs ends, by ye counsail of the teaching elders in this colony," is the phrase of the New Haven Colony Records in I66o, vol. ii, 373. A very notable entry in the town records of New Haven in 1723 directs that a certain piece of land be used "for the educating of children of Congregational or Presbyterian parents only, and for no other use whatever, forever, hereafter." Atwater's New Haven, I $5 \mathrm{I}$.

Note 25, Meals were hard to reckon with in the reigns of Elizabeth and page 240. James. It seems clear that most people of position in Elizabeth's reign ate their first meal at about noon. Harrison, in Holinshed, i, 287, says: "Heretofore there hath beene much more time spent in eating and drinking than commonlie is in these daies, for whereas of old we had breakfasts in the forenoone, beverages or nuntions after dinner, and thereto reare suppers generallie when it was time to go to rest. . . . Now these od repasts thanked be God are verie well left, and ech one in a maner, (except here and there some yoong hungrie stomach that cannot fast till dinner time) contentes himself with dinner and supper onelie."

Note 26 , page 240 .

In 555 the burgh school in Aberdeen began at seven o'clock, according to the report on Burgh and Middle Class Schools in Scotland. There was an intermission of an hour at nine, "when all 
were directed to hasten to breakfast." The school was then resumed from ten to twelve, and again from two to six. But most English schools were held unbrokenly from six to eleven and from one to six, and even at a later period, as we may infer from Brinsley. In another Scottish school, that at Elgin in 1649, work began at six and continued till six, with two hours' intermissionone for breakfast and one for dinner. Report as above, p. I 5 . I can find no trace in later schools of the bever taken in the schoolroom, which must have been the custom in the reign of Henry VIII. The statutes of St. Paul's School, as drawn by Colet, say: “ Also I will they bring no meate nor drinke, nor bottel, nor use in the school no breakfasts, nor drinkings in the tyme of learnynge in no wise," etc. Knight's Life of Colet, 308. The r.ours of St. Paul's School were from seven to eleven and from one to five. This, with the difference between Aberdeen in 1553 and Elgin in 1649, as given above, and some other facts I have noted, cause me to suspect that the longest hours came in only with the new zeal of the Reformation period. But Colet's statutes are very severe in refusal of holidays, etc. " Yf the master grantth any remedyes he shall forfeit xl s. totiens quotiens," etc. The holy days of the Church were interruption enough in Colet's time. As late as 1763 I find in Justin Forward's diary that he visited Hatfield's school, and advised a "vacancy," which was granted. Manuscript in my possession.

John Brinsley was a clergyman of Puritan tendencies, and a brother-in-law to the famous Bishop Hall. He has been less cited than his forerunners Ascham or Mulcaster, but he appears to have had practical ideas on the subject of school management in advance of both, and his books are most instructive to the student of the history of education, especially his Ludus Literarius and his Consolations for Our Grammar Schooles. The latter has a special interest for us, because it was written to promote the welfare of the schools projected for Virginia, as well as those in Ireland and Wales. It was submitted to the Virginia Company for approval before its publication. Among the reforms advocated by Brinsley were a somewhat later hour of beginning schools, a recess for breakfast in the middle of the forenoon, and another in the middle of the afternoon, and a large attention to the teaching of English.

The passage in Brinsley's Consolations, p. 43, is suggestive : "When our scholars coming to man's estate shall curse vs for page 244. 


\section{The Transit of Civilization.}

ChaP. V.

that by our blowes they were made dunses or deafe . . . or to hate all learning." "They think themselves the best schoolmasters when they teach little and beat much," says Becon. He says one might think them "vexed with some infernal fury." It should be remembered, in mitigation of censure on the schoolmasters, that in a civilization like that of the sixteenth and seventeenth centuries, discipline without corporal punishment would have been more difficult than in our later time. The pupils regarded their master as a natural enemy. This was hit off by a Dutch schoolmaster of that time, whose sign before his door showed a portrait of himself sitting in the midst of his uproarious and unruly scholars with a crown on his head and this legend be low: "Het gekroonde hoofd-sweer" ('The crowned headache). Schotel's Oud Hollandsch Huisgezin, 76. From this antagonism came the practice of "barring out," or, as it was called in this country, "turning the master out." There was an early instance of this turning out at William and Mary, in which the boys received encouragement from Governor Nicholson himself, and fired blank cartridges at Dr. Blair, the president. This custom seems to have died in England only in the nineteenth century. It lingered long enough in this country for the present writer to have partaken of a " treat " of apples served by one master to buy exemption from it, and to have had the bitter experience when about twelve years old of leading in an actual conflict of the kind, when the resolute master with stalwart help from without broke down the door casing and carried the house by storm. Addison at the same age was more successful at Litchfield in an enterprise of the kind, according to Dr. Johnson. The practice was very common in the seventeenth century. See the Gentleman's Magazine of 1828 , part ii, pp. 402-408. The custom of "taking the school" was set down as an old one in Aberdeen in 1568 , when the boys secured three days of vacation. In I604 the boys again "took the school " with guns and other weapons, and foraged for "puir folke's geir," such as "geisse, foullis, and ultheris vivaris." Burgh Records of Aberdeen, xxviii.

Note 29, Mulcaster, like his predecessor Ascham, was an admirer of page 244. the classical attainments of Queen Elizabeth, and so inclined to advise a higher education for women than was customary. But tradition was against hin. "I set not yong maidens to publike grammar Schooles," he says, "a thing not used in my countrie, I send them not to the vniversities, having no president thereof in my countrie." He says that maidens " taught to read and write, 
to sing and play, to speak daily spoken tongues, and of best $r \in$ putations in our times" compared well with men. Positions, I66. The Puritans naturally regarded Elizabeth's rule with disfavor, and her masculine acquirements seemed to them rather unscriptural. Anne Bradstreet was an example, however, of an educated woman in New England, though a reluctant Puritan, and An Cotton of a cultivated woman in Virginia. "For the first fifty years after the settlement very little is on record in respect to schools, and from the numerous instances of persons of the second generation who could not write their names, it is evident that education was at a low ebb. Female instruction in Farticular must have been greatly neglected, when the daughters cf men who occupied important offices in the town and church were obliged to make a mark for their signature. Yet the busiriess of teaching was then chiefly performed by women. ... Every quarter of the town had its mistress, who taught children to behave, to ply the needle through all the mysteries of hemming, overhand stitching, and darning up to the sampler, and to read from $\mathrm{A} B \mathrm{C}$ through the spelling book to the psalter. Children were taught to be mannered and pay respect to their elders, especially to dignitaries. In the street they stood aside when they met any respectable person or stranger, and saluted him with a bow or courtesy, stopping modestly until he had passed. This was called 'making their manners.' "' Miss Caulkin's History of New London, 395. "Children who did not attend school were taught to read at home, and nearly all could read, females as xvell as males. Writing was considered much less important, and it was not judged necessary that females in common life should learn to write." Judd's History of Hadley, 64. Compare Bailey's Andover, 13, footnote. Judd adds that girls were not permitted to attend public schools in Boston until 1790, and that the permission was not granted in Northampton until 1802. Mrs. Grant says that in Albany women could usually read in Dutch the Bible and a few Calvinistic tracts, but not English in 1704. Memoirs of an American Lady, 1, 33. Needlework was added to this. She adds with unnecessary detail, "This confined education prevented elegance." In Philadelphia in 1722 "flourishing on muslin and embroidering petticoats" was taught to young ladies along with French.

D'Ewes complains of the morals of the university: "Swearing, drinking, rioting, and hatred of all piety ... did abound Note 30 , page 247 . .. generally in the university ... so as I was fain to live al-

CHAP. V. 
CHap. V. |most a recluses life." It.is characteristic of the age that D'Ewes finds consolation in reflecting that the religious opinions of his licentious, riotous, and impious fellow-scholars were uncorrupted by " Anabaptisticall or Pelagian heresies," and that there was no bowing toward the altar. Autobiography, i, I4I. Libertines and blackguards in abundance, but no Baptists, Arminians, or Highchurchmen, thank God!

Note 3r, page 250.

The charter of William and Mary College in English is recorded in a beautiful contemporary handwriting in the manuscript book of Virginia Instructions, in the Library of Congress. It is printed with Hartwell, Blair, and Chilton's account of Virginia, and the copy of the latter in the Library of Congress is annotated by some critic, who notes slight variations in the sense of the English version of the charter from the Latin original. The phrase "studium generale" has a sense hardly appreciated by those who copied it from the ancient charter for William and Mary. See Heinrich Denifle, Die Universitäten des Mittelalters bis $1400, I-29$, for an exhaustive study of this word. On page 15 he says: "Der Dominicaner Ricoldus, de Montecrucis schreibt an der Wende des 13 und 14 Jhs. in seinem Werke gegen den Alchoran, er sei zu den Sarazenen nach Bagdad gereist, ' ubi generale ipsorum sollempne habeter studium.' Wie im Occident der Ausdruck studium generale im Sinne von Lehren Austalt für die studierenden der Christenheit genommen wurde, So wendete der Dominicaner derselben für das Hauptstudium der Sarazenen an." Blair's instructions from the General Assembly read: "You shall make it your business to peruse the best Charters in England ... having Regard alwaies to the Constitutions of this Government." P. R. O. Am. and W. Ind. Bundle 637. 
CHAPTER THE SIXTH.

LAND AND LABOR IN TIE EARLY COLONIES.

I.

Englishmen were accustomed to a land system the most intricate the world has ever seen. The feudal law in its passing had left behind a mass of technicalities, and the evasions of that law had given birth to a multitude of fictions. In many cases instruments of conveyance were ostensibly instruments to do something else, and they were often not registered, but kept secret. There was a jargon of land-law terms mastered by conveyancers, that made it sometimes difficult to transfer land. In the century preceding colonization there came in the custom of piling up whole vocabularies of conveyance in one deed, with endless tediousness of repetition of clauses and provisos. The statutes were stuffed at the same time until the reader "was made giddy by a continual recurrence of the same form of words in the same endless period." Law

came into disrepute as something hardly comprehensible, and a source of endless entanglements to the lay mind. Lawyers were forbidden in the colonial courts. In Virginia mercenary lawyers-

that is, lawyers who took fees-were almost wholly Note 2. forbidden until 1658 , when they were totally ejected.

Reeves, iv, 560.

Note I. 
Chap. VI. The New England colonies had a like prejudice, and would not suffer a single lawyer to becloud the acts of the early courts. When Massachusetts came to framing a working Constitution in $\mathrm{I}_{4} \mathrm{I}$ there was a rivalry between Ward and Winthrop, educated as lawyers, and Cotton, who wished to proceed on a theological basis. The lawyers triumphed, but they did so by holding to the severe simplicity of old English law. The laws were not even called laws, but liberties; a man had the liberty of being hanged in certain cases. Somebody saw the absurdity, and appended a note explaining that liberty meant law, and the experiment of using this term for laws was not again tried in Massachusetts. The Dutch had but one lawyer among them, and they pretended to be unwilling to give either side in a case the exclusive benefit of his skill. They refused him permission to practice. Thus it came to pass that the earliest laws were simple and direct. Decisions were based on common sense and the merits of the case, as seen by the magistrate. There were other forces that held land laws to simplicity. There was little land in America that had come through feudal tenure. Even the king as a source of title did not usually appear in the deed. In the later seventeenth century lawyers and conveyancers began to be sought after; their services could no longer be dispensed with. The colonial laws and deeds after the Restoration became somewhat more intricate, and affected the English in their style. But the habit of passing 
land easily had become fixed, and though deeds $\mid$ CHap. VI. might take on English forms and abound in repetitions, landholding remained substantially the same, the simple and direct ownership of the soil.

II.

There was one trait of land law that had survived from the middle ages-that had survived apparently from nobody knows what remote antiquity. It made so dry a matter as the transfer of land picturesque and dramatic. This was called livery of seizin-the delivery of possession. The seller stood on the tract to be conveyed and taking a bit of turf from the land, and, if there were trees, plucking a twig and thrusting it into the turf, passed it into the hands of the buyer. The custom was capable of many variations. Judge Sewall, of Boston, received seizin of six hundred acres of forest by "turf, twig, and splinter," as if to embrace all the possibilities of timber land. In the H. B. Adams, Cape Ann history of Salem it is recorded that John Rush took a twig from a growing tree and a bit of and Salem, 78. green turf and said, "Here, son Thomas, I do before these two men give you possession of this land by turffe and twigg." In turning over the primitive records in Virginia one finds that "livery and MS. York Records, 1645 . sesen was made of a turffe of the earth of the within written land." In other cases "twigg and Ibid., 164 I. turff" marks another form. Sometimes the livery is marked by a different form and personal estate is Note 3 . 
Chap. VI. included. One Colonel Henry Browne, wishing Surrey, Va., MS. Records, 1652 .

Note 4 . to give his whole estate for the benefit of his wife and creditors, delivers to them "one silver spoone, part of premises as a voucher to lead to intent, purport," etc. When a house was to be delivered the seller took hold of the ring of the house door and formally gave it into the hands of the new owner. The ground with its appurtenances was thus handed over in a manner suitable to illiterate times and restricted territories. But land in a new country became an article of frequent merchandise. Tracts of wilderness, remote and sometimes unsurveyed, could not be given by livery of seizin. In Maryland the mere certificate-the warrant entitling the holder to take up land-came presently to be passed about as current money. And, indeed, the custom of livery of seizin probably went out of use in America more rapidly than in England. In Virginia, the most conservative of the colonies, it was still somewhat in vogue in 1748 , when it is recognized in a statute. Perhaps this was a mark of oncoming decrepitude. For a thousand years and more it had existed without legislation; when it became necessary to mention it in statute law the usage had passed its prime. In England to-day the seller often passes a ferule into the hands of the buyer of land without leaving the court room. So does the faint shadow of ancient custom stretch itself across modern life, growing more attenuated until at length it vanishes, no one perceiving where it left its last trace. 
Chap. VI.

\section{III.}

One mode of holding land, the oldest known to the English world, dating far back of the feudal

system, seems very curious to modern eyes. It did not much attract the attention of lawyers in its time. Questions regarding it were settled almost wholly in the petty court of manor or township, and the great jurists had no call to discuss it. As a general rule it was a subordinate kind of landholding. The town community was tenant, as a whole, to the owner of the manor. The manor ownership might be litigated, might be taken away by violence, but the town held of the lord of the manor, whoever he might be, from time to which the memory of man runs not. If the ownership of the land came into question, it was as a whole. In this way it escaped almost entirely the notice of the land courts and of the older writers on the law of land. But as it went out of existence the township community began to attract the attention of the learned. Who should have the commons? What rights had the lord of the manor and the people under new conditions? And then inquiries were made by the curious into the origin of the commune, and presently a great literature has grown up about it mostly in a lifetime. Efforts have been made to connect it with similar forms in other countries. The great fact coming out in all this discussion is that the town commune was very primitive. It can be traced in 
Chap. VI. England back to the fifth century. It disappears in the prehistoric past in its full vigor. A considerable portion of the surface of England was cultivated in this way in the seventeenth century, and it shows how far human development can be carried without breaking an ancient shell of society.

The

village commune.

Note 5 .

IV.

What was this village commune? Setting aside the disputed points in its ancient history-whether the commune was a combination at first of serfs, or whether it was a free mark-it seems probable that it once held all its territory in common, and that at the earliest period the arable land was allotted annually. The advancement of civilization relaxed the severity of this communism. Little patches were dealt out permanently to residents, or at least to shareholders, but the division of land retained marks of the older order. The land of a single owner was scattered over the lands of the town apparently as last divided. The meadow, the pasture, the mast land, and the woodland remained an undivided common when William Marshall began the study of it in the latter part of the eighteenth century. The fences and gates were kept up by the proportionate care of the several cultivators, and the rents of the lord were paid by the "town" as a whole. In New England, where there was no lord, a town registry was established, and the town held the disposal of land in 
its own hands. "The furlongs"- - that is, the "furChap. VI. row-longs" - were held by each household, were fenced in a common field, and often for the first years of settlement were held undivided and allotted year by year. Each person had his "homelot right" and "acre right" in the undivided meadow, forest, and upland. These were at first sold as a unit, and were termed "an accommodation." The times of planting and of turning in of cattle were sometimes regulated in "field meetings" or "side meetings," after the immemorial usage of the English township. The common fields were in primitive towns but three. Two were in different sorts of grain, the third was taking its year of rest as a sheep and cow pasture. Each cultivator had to raise the crop decided on by the majority in the side meeting or field meeting. It was an animated Note 6. scene in a common field when all the commune was planting or harvesting. There were New England towns that went back to the original norm of the town, and cultivated the land by dividing it annually until the town should fill up. Then when the town was fuller, they divided their arable land, giving each an equal chance. Society was prone to fall apart in a new country. The town community held it together in common helpfulness.

V.

Agricultural villages were yet flourishing in The comEngland in the seventeenth century. Very many $\mid \begin{aligned} & \text { mune in } \\ & \text { England. }\end{aligned}$ 
Снар. VI. had gone down before the cupidity of sheep-raising landlords, but the greater part were yet in full vigor under one and another shelter. Some seem to have kept a stiff proportion of their ancient Gomme,
English Village Communities, 163 . rustic town; in Queen Mary's days there remained a prison and gallows in another. Persons seeking justice outside the borough for any matter occurring in the borough should lose their entire Ibid., 77. freedom-that is, their right of property in the community. Even in Connecticut one finds the right to appeal to higher courts was hampered and Ibid., 79. jealously watched. In England the townships in James I's time looked to overlords for protection. Some were resolutely independent.

The commune in America.

Note 7 .

\section{VI.}

That the New-Englanders were largely born to the commune is evident. They were mostly farmers, and farmers in that time were frequently found in village communes. Perhaps the small farmer was more susceptible to Puritanism; perhaps the condition of the towns was favorable to the spread of Puritanism. Threatened with inclosure of their "wastes" - their mast land, their woodland, and their meadow-these villagers embraced the religion of the discontented. In New England the origin of the commune was soon forgotten. In the time of the Revolution we find John Adams proposing to inquire who among the 
fathers of Massachusetts suggested this mode of Chap. VI. settlement. He had no notion of its English origin. From the first, Plymouth was organized somewhat on the communal model. Salem, after trying independent holdings awhile, adopted the same plan. The great migration of Winthrop seems to have brought along with it the plan of the village community as the very best one on which to settle Puritan churches and congregations. If it was predetermined, it was a masterstroke of policy; but whether it was a matter of forethought or not, the townsmen must many of them have been acquainted with it. Nearly the whole of New England adopted the same plan. From I know not how far east clear down the coast to Connecticut and Long Island, and down the Jersey coast to Delaware, the people organized in this way. One never hears any other plan proposed. The phraseology of the town community was theirs. The swineherd or hogreeve went through the town blowing an early morning horn, the cowherd, the goatherd, the gooseherd, the shepherd were all present, as needed in various New England towns. There were water bailiffs, there were drummers to call people to meeting and to make announcements, there were overseers of chimneys and of chimney sweepers, perambulators, cullers of staves and corders of wood, firewards and haywards or hedgewards, and all the half a hundred other occasional officers of the town. Their names passed easily from one to 
Chap. VI. another, like coins worn smooth. One thing they Note 8. missed-it was the lord and his rents. But when a Connecticut town moved to Newark they easily spoke of the quitrents as the lord's half-penny. It would have been the lord's penny in England.

Distribution of land.
Note 9.

Conn.

Rec., i, 30.
VII.

The land was distributed with more or less equality in some towns and with more or less inequality in others. The houses stood rather compactly about the meeting-house. Every man had his home lot, his share in the cultivated field, his right to feed his cows in the common pasture and in common fields when crops were off, and so on, duly awarded him. A part of the fence or a gate, a pair of bars or "a lift" was assigned to him to keep up. The town owned the realty and divided it according to its by-laws and its own good pleasure. There were town cows sometimes, there was always a town bull, and a town horse was kept at Salem. Town sheep were not uncommon; a herd of two thousand paid all the corporate expenses of a certain town in Connecticut. The town sometimes kept packs of dogs to hunt wolves with. The tradespeople who wished to settle within the bounds of the town made bargains with the "selectmen" or others having charge of "the prudentials of the town" for a monopoly. Its mill sites and other privileges were disposed of in this way, the townspeople agreeing 
to help build the mill; to a blacksmith they gave a monopoly. The ideas prevailing were rustic; Note 1 . we read of one village which had reached a transition stage and which was alarmed lest the community should be "ruinated" by the influx of people. It is to be remembered that no New-Englander, unless from choice, was solitary. He was always a member of a community and therefore civilized. Thus grew New England.

\section{VIII.}

The word town underwent a change in New England, or at least a provincial sense became the main sense of the word. It did not mean at first a town, but a group of farmers engaged in agriculture on a particular plan. The New England village was almost precisely the same at the outset as the English farming community. But it was in a new country where there is a chance to change, where change is inevitable. In the first place, the township in Massachusetts took on governmental functions. It became the political unit; this was its capital change. Deputies were elected to the Legislature from the "towns," large and small. The counties sank into insignificance, the towns were the sources of power. In the next place, the town boundary was also the boundary of the parish. The parish in Massachusetts was of primary importance. And, in the third place, the rulers, finding themselves freed from some of the cares of

Political importance of the town. 
CHAP. VI.

government by the autonomy of the towns, made even the farms attachments to the several towns. The town meeting, from being a side meeting to assign a date for the putting in and out of cows, became a place where the very sources of political power lay. The leading magistrates were outvoted by the representatives of the towns over and over. This was unexpected in a day when the magistrate was reverenced as the appointed of the Lord. The magistrates offered strong resistance, but the stronger resistance of the commons would not down. Efforts were made to overrule the lower House, but the deputies, having got the bit in their teeth, carried things their own way, and then the government fell into the hands of the towns, or rather, as has been said, into the hands of the churches, whose members did all the voting.

\section{IX.}

Society in the South.
The custom of granting farms in the first generation to prominent citizens in return for the assistance given in colony planting was discontinued. In the rivalry between independent towns and farms the towns by natural selection won the day. The prominent man, a little more eminent than the others, was content to take a larger share in the town instead of a separate grant. After the first generation there were fewer men of distinction engaged in planting towns, and hence fewer occasions for special 
grants. The New-Englander became exceed- Cнap. VI. ingly fond of the town system; he did not think of doing without it. Everywhere that New-Englanders went in the first and later generations the town system went with them. But it did not elsewhere acquire any such prominence as in Massachusetts and Connecticut. There were no political privileges, and the church was not of the prevailing order. Long Island, New Jersey, and certain regions in the Delaware Bay all had the inevi- Note rr. table town plan. One or two churches moved away into South Carolina and Georgia, where their village plan was lost in the larger agriculture of the South. If we had the evidence that is Note 12. perhaps lost, we should find that the township or village community could be found germinating in the Southern colonies. Such a sub-colony as that Smith of Nibley MSS., 57. of Barkly or Berkley, to which an "incorporacion by some vsuall or fit name" was promised, must Note r3. have contemplated common lands and other elements of the commune. That and its rustic ally the hundred, and its civic type the borough, were the form in which nearly all the local government of England was cast. But nearly all the men of Barkly perished at the hands of the Indians or otherwise. Indian massacres, the growth of a staple demanding much land, and the consequent rapid development of territorial greed, soon destroyed every vestige of the town in Virginia. A "hundred" in I660 proved that a "commons" had been granted to it in I631. If we look to Maryland it is hard 
CHAP. VI.

Johnson's

Old Md.

Manors.

Kilty's

Landholder's Assistant, ch. v.

De Vries and Geo. Donne's MS.

Bodleian Library.

Contrast between the North and South. to make out whether manors with "courts leet" established there very early had jurisdiction of commons, as is probable from the usual organization of a manor. But the circumstances were most unfavorable to the community; the great staple of tobacco set people's teeth on edge to become rich out of it. Cultivation almost from the start began to change its character. Great and greater shiploads of bond servants, free-willers, kids, and convicts were unloaded in Virginia and Maryland and sold for four years' service. For half a century or more large estates with white bond servants were the rule. In 1670 there were three times as many white bond servants as blacks in Virginia. Within ten or fifteen years after that, as the century drew to a close, Virginia ceased to buy white servants in any numbers, and plantations worked by black servants became the rule.

$\mathrm{x}$.

A very usual method of holding land in England was by the manorial system. The manors were entailed to the eldest son or other heir of the manor lord. But parts of these manors were village communities from the most ancient times. In New England they made village communities without any lord of the manor, and quitrents were left out of the count. The granting of farms quite independent of the town contemplated another English mode of landholding. But just as agri- 
cultural villages were crowded out in Virginia, so CHAP. VI. were independent farms driven to the wall in the Northeast. An order went forth that farms should belong to the towns in which they were situated. It was inconvenient to have them separate. The Church was the drilling ground to keep the people strictly in line with advanced Protestantism. The farmer could have no rights in common fields, his cattle were foreign to the pasture, his pigs had no right to pick up nuts from the common woodland, he had no acre rights when dividends were made, but he must attend the town church and pay the dues levied upon him for the clergy and other town burdens, and all burdens were put directly on the town. Individuals were unknown, the town was the taxpayer and the landowner. Sometimes, as at Salem, the town bought out a man's holdings, his "accommodation," exchanging therefor a farmstead carved out of the great unappropriated wilderness. But the favorite method of settling land came to be in a colony or town. By this means the ecclesiastical power was greatly augmented. The minister was usually the one educated man in the parish. He knew some Latin and Greek, and he had even a smattering of Hebrew. He was educated in what was the only branch of knowledge affected by minister or layman-theology. His dominance over the unlettered was tolerably complete. On the other hand, the Southern planter, with long stretches of woodland between him and his neighbors, could 
Chap. VI. cultivate his wide fields in almost entire independence; his code of morals even was mostly his own, but his public interests were as extensive as his county or his province. This state of society begot self-reliance, and produced more leading statesmen than the other; but the people lacked the New England cohesion and susceptibility to organization, without which the statesmanship of the Revolution would have been vain. The Southerner, from his isolation and from other causes, became hospitable, eager for society, and in general spontaneously friendly and generous; the New England people became close-fisted and shrewd in trade; it is a trait of village life. But the benevolence of New England was more effective than that of the South, because it was organized and systematic. The village life of the extreme North trained the people to trade, and led to commercial development, and it made popular education possible. The sons of the great planters at the South were averse to commerce; they were also the most liberally educated and polished in manners of all the colonists; but the scattered common people could have few schools, and were generally rude and ignorant, even when compared with the lower class of New-Englanders, who stood a chance of getting some rough schooling, besides a certain education from the meeting-house and the everrecurring town debates. 
XI.

A stranger might in old New England find a constable at the door some morning to warn him to Strangers forbidden. leave. He was not expected to go, but his landlord must give security that he would not be chargeable, or at least the town was quit of him. Peopile attracted by the superior medical skill of Boston physicians were thus warned. St. Clement's Manor, in Maryland, at its Court Leet, orders John Old MId. Manors, 15. Mansell "to remove his inmate or give security." The towns had done so from the most remote times. Even in the Salic law, a thousand years before, no person was suffered to remove from one villa to Seebohm, The Salic Law, 359, another. A trace of this is found in the Connecticut law that "noe Inhabitant shall have power to Rogers, Work and Wages, make sale of his accomodation of house and lands vntil he have first propounded the sale thereof to the Towne ... and they refuse to accept of the sale tendered." The town community is dead in New I07. England, though its methods of government remain, and even in the West and South there are traces of it in the language. In the old common field, strips were allotted from year to year, but one piece of land belonged to nobody. It was called "Jack's Land." Here the plowman left his plow, his hoe, his seed to the hospitality of an undefined somebody called Jack. The author of "Wonderworking Providence," a New England captain, calls Ireland “ Jack's Land." It was nobody's country ; one man and one party after another might take

I Conn. Rec., 35I, I660. 
Chap. VI. possession. Curiously enough, the word survives in America in an old game, played on a slate, where all drawn games are credited to "Jack," and are marked in a division called "Jack's Land."

Note ${ }_{4}$. It is the very last attenuated ghost of the ideas of the ancient commune.

\section{XII.}

The Virginia parish.

MS. Records of various parishes, in Fairfax Seminary. Note 15. Accomac Records, 1632.

Records of Petsoe Parish, in Fairfax Seminary.
In Virginia and the South the parish vestry took the place of the township in New England. Virginia was the Southern model as Massachusetts was the Northern. In the extant parish records of Virginia the vestry makes a contract for building a church, ordains a referendum for locating a church, and employs and dismisses a minister, builds a paling fence about the church, and "distreynes" for tithes. The vestry also opens roads, appoints overseers of roads and holds them to account, levies fines for bastardy and concubinage and for disorder in church, orders the land processioned, relieves the poor, binds out "orphants," appoints side men or collectors, and objects to the admission of non-residents lest they be chargeable. The parish also in one case elects a "select vestrye" from each of three precincts. In 1694 Petsoe Parish divides itself into eight precincts for the processioning of land. Here is nearly everything that was done by the New England town transacted by the vestry of a Virginia parish. The parish in Virginia stretched far-usually over an entire 
county; in New England it was restricted to a Chap. VI. town.

The processioning of land was observed by the Virginians between Easter and Whitsunday. They made formal processions about the bounds of their several tracts, renewing the marks in the line trees. When a division line had been thus marked three times it was no longer open to question. In Massachusetts, Connecticut, and Long Island the townships, as landholders, were " to go the rounds" at regular intervals. Each individual owner of plowland and mowland within the town must trace his boundary every winter if his adjacent neighbor exacted it. The colonists were thus following a custom whose origin was lost in the obscurity before written records.

\section{XIII.}

The leadership of the great families was sustained in New York and in the colonies south of Pennsylvania by primogeniture-the prerogative of the eldest son to inherit the landed estate in case the father left no will. Custom followed the law, and fathers who willed their property usually left most or all of the land to the eldest son, as belonging to him by prescriptive right. To primogeniture the aristocratic colonies added the dead hand of entail, by which the land was sent down for generations in the line of the eldest male. Even a clumsy fiction, called in law "com-

Inheritance. 
Chap. VI.

mon recovery," by which the entail might be broken in England, was forbidden by statute in Virginia, and was not accounted applicable to the other colonies.

The Pilgrims at Plymouth and the Massachusetts Puritans had belonged to that politico-religious party in England which sought the abo-

Plymouth Records. lition of certain old abuses. As early as 1636 Plymouth enacted that land should be held after "the laudable custom, tenure, and hold of the manor of East Greenwich "- that is, in an ancient Saxon way preserved at the coming of William the Conqueror by the county of Kent. One characteristic of this tenure was that it divided the lands equally among the sons in case there was no will. Massachusetts, which expressly abolished many of the worst features of feudal tenure, by name, gave to the eldest son a double portion according to the Mosaic code, but divided the rest among daughters as well as sons. This system prevailed throughout New England. Primogeniture had come to be esteemed a natural right, and the Massachusetts leaders felt obliged more than once to defend themselves from the charge of having "denied the right of the eldest son." They answered by showing the comparative insignificance of land in a new country, and took refuge behind the example of Moses. Pennsylvania took the same middle course of sheltering innovation under the law of Moses by giving the eldest son a double portion. The laws of some of the colonies made the 
land liable, to a greater or less extent, with perChap. VI. sonal estate for the debts of the deceased, which robbed the eldest of a part of his "insolent prerogative"; but it was not until the shock of the Revolution that primogeniture and entail were swept away, under the leadership of Jefferson and others. But land was so abundant that a thrifty younger son often earned in a lifetime a better portion than his elder brother. The eldest son's double portion in New England survived the Revolution for some years. A very ancient mode of inheritance prevailed in some English boroughs, called among lawyers "borough English." By this custom the lands descended to the youngest son. It found no lodgment in the laws of the colonies, so far as I know; but in New Hampshire it was a widespread custom to leave the homestead to the Note 16. youngest, who remained at home and cared for the old age of his parents. This reasonable form of the custom of "ultimogeniture" lingers yet in certain parts of the country, as, for example, in some of the northern counties of New York. The other custom of a widow inheriting a third of her husband's'estate is even more widely prevalent, and is a matter of law in most of the States.

XIV.

The problem of England in the days of James I was how to be rid of its poor. They had, many of them, been turned out of a living by the inclosure

Serfdom and apprenticeship. 
ChaP. VI. Note $\mathbf{7}$.

Harrison in Holinshed, i, 314.

of commons in the mania for sheep husbandry, and some of them had had the villages pulled down about their ears. They were sent a-wandering, living as they could live by hook or by crook. Necessity made many of them rogues, and the desire to have done with rogues was so intense that England hanged its thieves out of hand. Henry VIII thought to be rid of such vermin of society, and he hanged, if we may believe Harrison, twoand-seventy thousand, including "great theeves, pettie theeves and roges." In Elizabeth's reign three or four hundred felons were eaten up annually by the gallows, and James I merrily carried on the work of extermination; one reads of "twenty hanged up at a clap," in one place. But the vagabonds did not grow fewer.

Recent serfdom had left its mark on the poor man. He had been freed, not from benevolence, nor from any motive having regard to the personality of the serf. Wickliffe and others had taught that it was meritorious to free a man from bondage who was a Christian-that is, who had been baptized. This scruple fitted to the churchly conscience of the age; it grew more and more exigeant. "We think it pious and meritorious with God to make certain persons absolutely free from the yoke of servitude who are at present under villenage to us," said Henry VIII. Elizabeth and James, less scrupulous on this point, proposed to sell to those whose blood was tainted with slavery Note 18. the privileges of freedom. It was not till the 
eighteenth century had dawned that Chamber. CHap. Vir. layne's State of England, an annual publication, Chambercould drop its set phrase, "but few now in England," and say, "Now slavery is entirely thrown away and every Servant Man or Woman are properly hired Servants." But the habit of regarding layne, 1696-1 702 . the peasant as a recent serf had its influence in the treatment of him.

The "spirit," who was later called a crimp, was on the watch for him. Did they need more soldiers in Flanders? The spirit, by means best known to himself, packed off the poor man to Flanders. He was equally ready to ship him to any other country for a reward. The Virginia colony began to ask for people. The wilderness was hungry for laborers. The spirit shipped little children by the score down the Thames and off for America. Parents followed the vessels all the way to Gravesend, but the law would not help them; Virginia wanted laborers. Sometimes a parent could pay enough to get the lad released. Men were carried also to that abode of hopelessness. From the first there were two general classes: free apprentices and convicts mostly for petty crimes. "Apprentices," says Chamberlayne, "are a sort of servant that carry the mask of Pure villains or Bond slaves, differing however in that Apprentices are slaves only for a term and by covenant." 
Chap. VI.

Servants in the colonies.

Donne's MS.

See note I6, chapter v.

Compare Diary of John Harrower; Am. Hist. Rev., vi, No. I.
XV.

From the outset there were in New England as well as in Virginia apprenticed servants, who had been bound for a long term before leaving England, and were treated as a recognized species of property. Winthrop speaks of the "money" the three hundred servants had cost that they were enforced to set free for want of food. Cradock and others who did not come to New England sent servants to take care of estates for them. In I629 De Vries, the Dutch traveler, saw English men and women staked and lost at cards, and he bluntly told the Virginians that he had "never seen such work in Turk or Barbarian." George Donne, the author of a manuscript in the Bodleian, saw servants brought to Virginia by the shipload after 1630 , and he describes the horrors of the traffic, their insufficient food, their ragged and barefoot condition, and their landing far from their destination and being forced to march the rest of the way in their enfeebled state. Nearly all the emigrants that came between 1620 and 1650 were bondsmen. This does not imply that they were not some of them educated, for many Latin-school men were obliged to sell themselves to the crimp. After the Restoration servants were sold in great numbers to Virginia. Fifteen hundred a year is the estimate of Berkeley at a time when Virginia contained but two thousand black slaves. As the term was for four years, there were six thousand 
white slaves always in bondage there. Before CHAP. VI. I550 the term of some was ten years or more, and that of many 'was seven or eight years. After the restoration of the Stuarts in 1660 the term of service was permanently reduced to four years.

\section{XVI.}

English laborers bound themselves to serve a term of years, fairly hoping to better their condition in America; and men in domestic or other trouble would sell themselves for a term of service in the plantations, plunging into the abyss and trusting to luck to come up in better plight in a new world. Husbands forsaking their wives lost their identity in the transport ship, and wives f eeing from unbearable husbands were swallowed up in the flood. Runaway children and fleeing apprentices were greedily welcomed by the crimps; felons and prison breakers pursued by hue and cry were quickly safe on board. In those days of slow communication, renegades of every sort were as utterly lost to their old lives in America as they could have been had they migrated to the moon. It was an age of flogging; criminals, soldiers, sailors, pupils, children, and now and then even wives, were thought the better for scourging. One ought hardly to be surprised, therefore, at the numerous and cruel whippings of English servants, women as well as men, who were scourged naked with hickory rods and washed

Fate of servants. 
Снар. VI. with brine; the punishment continuing sometimes at intervals for hours, or being renewed day after day. There were also in use, by masters and overseers, thumbscrews, sweatings, and other such devil's devices. The food allowed was sometimes a scant diet of Indian meal. The sick servant was neglected lest the doctor's charge should exceed the value of his remaining service; and one thrifty

Danker's Journal. master in Maryland required a servant, sick of a mortal disease, to dig his own grave in advance, in order to save the other men's time. In I705 Virginia prohibited the secret burial of servants and the whipping of "Christian white servants" naked, without the consent of a justice. Great numbers fled away from the sharpness of bondage, taking the risk of cruel punishments and an extension of their terms if captured. During the existence of New Netherland, Dutch servants broke away to New England or Maryland, while English servants from both directions made their way to the Dutch territory. With New England the Dutch had at one time a treaty for the return of those "who carried their passports under their feet." To get away on shipboard, to seize a shallop and make off to a neighboring colony, and represent themselves as shipwrecked mariners, and to fly to the Indians, were favorite devices of runaways. So great was the number of fugitives that "inferior persons" were always liable to arrest on suspicion. North Carolina was filled with runaways from Virginia. In I 663 a dangerous conspiracy of indentured servants 
was discovered in Virginia, and a general fear of Chap. VI. the class, among whom were many desperate characters, probably prompted much of the severe treatment inflicted on bondmen. The Pilgrims found that servants led astray "the unstaid and young." The Massachusetts colonists before starting essayed at considerable cost to sift their servants, excluding a corrupt element; they even sent back two boys who had shown vicious propensities on shipboard. But the large proportion of penalties meted out to servants during the first years of the colonies shows how slight was the effect of the sifting process. Even in the colonies where the convict element was shut out, many of the servants were obtained from dangerous classes, such as "sturdy beggars, gypsies, and other incorrigible rogues, idle and debauched persons." They could "eat till they sweat and work till they freeze," in the quaint words of a traveler in New England. It was probably from those who had been servants that the sea rovers fitting out in the colonies found recruits. The pirate James, when short of hands, lay off the Virginia coast and captured transport ships, many of the convicts and servants in them preferring to risk a halter in cruising "on the grand account" to pining in colonial bondage. In some instances the criminal transports rose and slaughtered the crew, taking the ship into some out-of-the-way harbor and escaping. The degradation of the women servants was a continual source of evil; laws were made to correct their immoralities, and other laws 
Chap. VI. to prevent these "Christians" from intermarrying with the heathen Africans. In all the colonies there were those brought as servants, even as convicts, who rose to wealth through industry and frugality, two virtues on which a new land pays high premium. Some founded families that attained to honor and influence.

Convict servants.

State Papers, passim.

\section{XVII.}

The severity of English penal laws occasioned evasions of all kinds; for Anglo-Saxon people prefer to reform an abuse by avoidance rather than by direct abolition. The old provision for "benefit of clergy" was stretched to an absurd comprehensiveness. The need for men in the colonies offered a new opportunity for merciful evasions of the death penalty in cases of minor felony. It became common to pardon thieves on condition of their accepting a seven years' term of service in the colonies, and the English State-Paper Office has many curious petitions for this commutation. As early as I622 a horse thief indicates that he much prefers service in Virginia to hanging. At a later period a husband is found petitioning on behalf of his wife, condemned to death for stealing three-andsixpence, that she might be transported to any plantation. After the Restoration it was enacted that justices, at their discretion, might send "loose and disorderly persons" to the colonies, and at intervals a hundred or so of "Newgate birds" were taken in a close lighter from Blackfriars to Wool- 
wich, where they were put aboard ship for CHAP. VI. America.

Bristol was the chief center of the colonial trade; here even the small traders and sometimes the peddlers had ventures in the colonies. Bristol, therefore, naturally took the lead in the servant trade, and most of the great officers of the city became involved in kidnapping. When, in Bristol, a man was on trial for some small crime, the petty officers would persuade him to beg for transportation in order to escape being hanged. These transports were then assigned to the mayor and each of the aldermen in turn, who sold them to the plantations, and grew rich from the spoils of the poor and the desperate. In the most paradoxical scene in judicial history the worst of judges, George Jeffreys, himself reeking with corruptions and cruelties incredible, is found arraigning aldermen of this opulent city for their share in this trade. Ordering the scarlet-robed mayor from his seat on the bench to a place in the prisoner's dock, he cried, with brutal exultation, "See how the kidnapping rogue looks!" He ranted at the aldermen in words too vile to be reprinted. Yet the selling of condemned men and the condemning of men that they might be sold were practiced openly at the court of James II at this very time. The ladies of the queen's bedchamber and the queen herself eagerly snatched at the profits from the sale of the rebels of Nonmouth's rebellion, whom Jeffreys had just then condemned; even 
Chap. VI. William Penn begged for twenty of them for the Philadelphia market.

Introduction of slaves.
XVIII.

In 1619 a "Holland man-of-war," short of water and food, put into the James River, and cast anchor before the only English settlement on this side of the globe. The captain was forbidden to land, but as he threatened to throw overboard some slaves captured in the West Indies, Captain Kendall, commanding at Jamestown, exchanged some "presents" for them. These fourteen "negars" were the first slaves in English America. The opening of new settlements and the lighting upon new staple products produced a demand for unskilled labor which the English "spirits" or crimps could not adequately supply. Negroes were therefore brought from the West Indies, and afterward direct from Africa or Madagascar. The labor of slaves increased the ability of the colonies to "take off" English goods; it is therefore not surprising that a Committee on Foreign Plantations, soon after the Restoration, declared that "black slaves were the most useful appurtenances of a plantation."

The English serfs had received their freedom chiefly on theological grounds as fellow-Christians, with some additional weight thrown into the scale by their being fellow-Englishmen. But freeborn Englishmen were by custom sold into severe bondage for long terms, and even sent beyond seas 
in large numbers; there could, therefore, be no repugnance in the minds of the colonists to the enslavement of blacks, who were not only pagans, but so different in appearance as to seem to be another species, not entitled to human consideration. At least, if they came from Adam, they were by some theological experts identified with the cursed descendants of Cain, for Ham was thought to have found a wife in the land of Nod.

XIX.

Slavery is more ancient than historic records. In the centuries of warfare between Christians and Mohammedans, the practice of enslaving captives outlawed by their " infidelity" had prevailed. Negroes were easily confounded with the Moors, and thousands of blacks were annually brought into Europe for sale as early as the middle of the fifteenth century; and a century later, in 1553 , one finds four-and-twenty of them brought as far as England. From Spain first, and then directly from Africa, black slaves had been carried to the Spanish colonies to develop the mines. The Royal African Company of England announced to Charles II, in I663, that the very existence of the plantations depended on an adequate supply of negro servants; and though their declaration was due to cupidity, it was at least true that all rich and successful American colonies up to this time had possessed slaves. So late as 1735 the Lords 
Chap. VI. Commissioners of Trade declared that the colonies " could not possibly subsist" without an adequate supply of slaves. Indeed, the first effect of the introduction of slaves was a rapid advancement in subduing forests and opening sources of wealth.

For nearly sixty years after the beginning of negro slavery here, there seems to have been no scruple or question about it. The lifelong bondage of negroes was tacitly justified by their heathen condition. When, in 1677 , the question was first raised in an English court, Africans were held to be slaves by the custom of merchants and "as being infidels." This notion was so general that very many planters resisted efforts to instruct their slaves in the Christian religion, lest baptism should emancipate them. To remove this obstacle the Virginia Assembly had enacted, in 1667 , that the conversion of a slave should not invalidate the owner's claim to his services, and similar laws were afterward made in most of the other provinces. But these laws were merely of colonial authority, and were not sufficient to overcome the scruple of covetousness. A proposal from England to encourage the conversion of the negroes "would not go down" with the New York Assembly in 1699. Philanthropic exertion for the negro was at first wholly religious, seeking his conversion not so much for the good of the negro as for the glory of Christianity. The attention of James II having been called to the pagan condition of the negroes, he resolved at the council board, in 1685 , 
that all the slaves in the plantation should be chrisChap. VI. tened; the thought of baptizing them in a mass by royal order, whether they would or no, was no doubt doubly pleasing to him as a zealot and as a lover of arbitrary methods. Efforts to convert the slaves in the seventeenth century were few and languid, the most notable being those of the superannuated Eliot, in Massachusetts. There were a few individuals who, like William Penn in 1700 , had "a concern for the souls of the blacks"; but many held them to be quite without souls, and hence not proper objects of concern.

$\mathrm{xx}$.

The first voice in America to speak against the perpetual bondage of man to man was heard in a memorial of some Friends of Germantown in Pennsylvania. This protest, in vigorous broken English, was addressed to the Philadelphia Yearly Meeting in 1688, and it opened an agitation which resulted, seventy years later, in bringing the Philadelphia Quakers to a conclusion opposed to slaveholding. In the fundamental law of Massachusetts and Connecticut, villanage and other feudal servitudes were prohibited, and in 1646 the Massachusetts General Court actually undertook to send back to Africa negroes who had been kidnapped by a slaver, and to send with them a letter of apology and explanation. But the Calvinist reverence for the law of Moses was a less elastic

Antislavery movements. 
CHAP. VI. standard than the "inward light" of the followers of Fox. If the early Puritan, bound to the letter of Scripture, was less likely to run into aberrant fanaticism than the Friend, he was also less quick to gain new and modern views of duty. J Refusing to participate with "man-stealers," the textual conscience of the Massachusetts forefathers did not shrink from selling Indians captured in war into chattel slavery, or from buying slaves who appeared to have come into bondage otherwise than by downright kidnapping. These nice distinctions could not be kept up, and thousands of negro slaves were sold into New England without any question for conscience' sake. The scruple about human liberty with which the Puri$\tan$ forefathers had come to this country had been swiftly forgotten. Some merchants of Boston were engaged in the Guinea trade, of which, however, Newport was the great center. Before the antislavery writings of the Quakers, Hepburn, Burling, Lay, and Sandiford, had appeared, an influential but rather timid voice, that of Judge Sewall, was heard opposing the importation of slaves to Massachusetts. He had been led by the narrow theological spirit in which he was bred into grievous mistakes in the witchcraft trials, but he was an honest and even a scrupulous man. Fond of popular favor and shrinking from censure, it cost him a struggle no doubt to give to the press, in 1700 , his little tract against the slave trade, entitled The Selling of Joseph. Its influence was probably not great. 
So closed the seventeenth century. The prog- Crap. VI. ress in humanity had been very slight. The number of bond servants was constantly increasing; the black tide of African slavery was ever swelling. No voice worthy of the name was yet heard in protest.

\section{Elucidations.}

".'Fine and recovery,' 'conveyance to uses,' 'lease and releases '-all the circuitous forms that evasion had been compelled to assume-survived, together with the whole storehouse of factitious science that had grown up round them. Once launched into existence, the system of private and unregistered conveyance had generated a science and a vocabulary applicable to the numberless ' estates' created in law, which made every title a matter of intimate personal history ; hence arose the necessity of investigrations requiring the most practiced and recondite knowledge of the old body of statute law which feudalism had left behind it." Hoskyns, The Land Laws of England, in Systems of Land Tenure, p. 183 .

See the note on p. 482 of Hening, vol. i, on the alternate forbidding and licensing of lawyers in Virginia. In 1642 the new governor had things his own way and admitted attorneys; in 1645 mercenary attorneys were expelled, in 1647 the act was made stronger, in 1656 all acts against mercenary attorneys were repealed, and in 1658 a vote of total expulsion was taken.

"The particular usages of the Saxons, however, were very similar to the present. The twig and turf were the simplest method of livery, and by the twig and turf did they give seizin to the purchaser. When grants were made to the church, a twig was usually laid on the altar. This occurred so frequently that it would be useless to cite instances in its support. A tree growing on a soil was regarded as a part of it, hence a branch of it served to give seizin. ... When Ulphus, king of Deira, gave lands to the church of York he 'took the horn, wherein he was wont to drink, and filling it with wine, kneeled before the altar' and deposited it as a symbol of possession. ... In the time of

Note 1 , page 273 .

Note 2, page 273 .

Note 3, page 275 . 
Chap. VI. Henry III, William Earl of Warrenne and Surrey, on a grant made by him to the priory of St. Pancrace, delivered seizin by the hair of his head." Watkins, Law of Tenures, pp. 81, 82, note xxxiii. See the article on Charter Horns in Andrews's Old Church Lore.

Note 4, page 276.

Note 5, page 278 .

Note 6, page 279 .

Note 7 , page 280 .
In some parts of England and Ireland tenures are by the custom of some manors conveyed by a bit of rush, straw, or hay. I have this by report as to Ireland, and in the present day. See also the custom of Yetminster, Dorset, in Watkins on Copyholds, 544 .

Private property in a strip in a common field came in only when fields become permanently arable. Nasse, I I. North Devon common lands were cultivated one or two years and then left to pasture in the latter part of the eighteenth century. Marshall's Rural Economy, 259. New England had land in considerable quantities reallotted every year at first. Land was still allotted thus in England in some places. It ought to be remarked here that Rhode Island was first organized into towns, and for a long time was a congeries of independent towns. From the vices of that system the State has not yet recovered. First Assembly of Rhode Island, I 5. Rehoboth, on account of its remoteness, was for a long time virtually independent, and was built in a semicircle. Newman's Rehoboth, 15, I6. In Stiles's manuscript I have seen an account of a town built in a circle about the church.

Mr. Seebohm calls attention to the animated scene in the common fields at the time of planting, as described by Piers Ploughman in the prologus :

" A faire field full of folke fonde I there bytwene Of alle manner of men the mene and the riche Worchyng and wanderyng as the world asketh."-Text B.

Mr. Ashton, in his Humour, etc., of the Seventeenth Century, gives this :

"A Lord, that purpos'd for his more availe To compass in a Common with a rayle, Was reckoning with his friend about the cost And charge of every rayle, and every post ; But he (that wisht his greedy humor crost) Said, 'Sir, provide you Posts, and without sayling, Your neighbours round about will find you rayling.' " 


\section{Land and Labor in the Early Colonies.}

And this other:

CHAP. VI.

"There be many rich men, both Yeoman and Gentry,

That for their owne private gaine hurt a whole country ;

By closing free commons, yet they'le make as though

'Twere for common good, but I know what I know."

A penny an acre was the result of knight's fee system as shown by Seebohm very ingeniously, p. 39. Towns paid quitrents as a whole in New York State. There is never any separation of a town into severalties in any State. The town processions the land, pays taxes, etc. Livingston and Smith's Laws of New York, vol. ii, 237--249. In the Grants and Ceremonies of New Jersey of Leaming and Spicer, 1664, it is provided that the lots shall be of certain sizes, "excepting Cities, Towns, and the near Lots of Townships. By 1672 towns were becoming common, and the regular laying out of Land, Rules for building each Street in Townships and Quantities of Ground for each House Lot, the same is left to the freeholder or first undertaker thereof." The antiquity of the swineherd may be appreciated by the mention of $\mathrm{h} \mathrm{m}$ in the Thorold Rogers in the Middle Ages, Work and Wages, 83 .

The law that each cultivator was accountable for a portion of fence, and must pay the damage done by cattle intruding, was as old as the laws of Ine in the seventh century, and probably much earlier. This equitable law existed in New England, New York, New Jersey, etc., a thousand years after. Compare Seebohm's Village Community, I Io.

Of primitive town government no better outline is afforded than that found in Connecticut Records, i, 30 (I639):

"The Townes of Hartford, Windsore, and Wethersfield, or any other of the Townes within this jurisdiction, shall each of them have power to dispose of their owne lands vndisposed of, and all other comodityes arysing out of their owne lymitts bounded out by the Court, the libertyes of the great River excepted, as also to choose their owne officers, and make such orders as may be for the well ordering of their owne Townes, being not repugnant to any law here established, as also to impose penaltyes for the breach of the same, and to estreat and levy the same, and for non-payment to distrayne, and yf there be noe personall estate, to sue to the Court to sell his or their house or land, for making satisfaction. Also each of the aforesayd Townes shall have power by a generall consent once every yeare to choose out 3,5 , or 7 of

Note 9 , page 282.

Note ro, page 283 . 
Chap. VI. their cheefe Inhabitants, whereof one to be chosen moderator, who having taken an oath prouided in that case, shall have a casting voice in case they be equall, $\mathrm{w}^{\mathrm{ch}}$ sayd $\mathrm{p}^{\mathrm{r}}$ sons shall meett once in every 2 monthes \& being mett together, or the maior part of them, whereof the moderator to be one, they shall have power to heare, end and determine all controversies, eyther tresspasses or debts not exceeding 4 os. provided both partyes live in the same Towne; also any two of them or the moderato ${ }^{x}$ may graunt out summons to the party or partyes to come to their meetings to answere the actions ; also to administer oath to any witnesses for the clearing of the cause, and to give judgment and execution against the party offending. But yf eyther party be grieved att the sentence, he shall haue liberty to appeale to a higher Court, $\mathrm{p}^{\mathrm{r}}$ vided it be before iudgment and execution be graunted. But yf it fall out there be noe ground for the appeale, the Court to confirme the iudgment and give good cost and fine or punish the party appealing."

Note II, page 285 .

Note 12 , page 285 .
Of town communities in "Delewer" Bay in I670 the following is from Denton's Brief Description of New York: "These persons being thus qualified settle the place and take in what inhabitants to themselves they shall see cause to admit of until their Town be full; these associates thus taken in have equal privileges with themselves and they make a division of the Land suitable to every man's occasions, no man being debarr'd of such quantities as he hath occasion for, the rest they let lie in common till they have occasion for a new division, never dividing their Pastureland at all which lies in common to the whole Town." There is some ambiguity in Denton's description, and the towns may refer themselves to New Jersey and New York. An instance of village community of French origin is found in Parkman's Discovery of the Great West, p. 7. Here there are town lots with arable land outside of the manor and an annual rent to the lord of the manor. Parkman's authority is Abbé Faillon's La Colonie Française in Canada.

In enumerating "The Common Land of the companie," Sir Edwin Sandys says, "three thousand in each of the fower old Burroughes." Here the borough is made the local unit, as was frequently the case in England-a district with common lands. The Records of Virginia, p. I5. In New England the town became the borough for representation; in Virginia the borough or hundred began, but the unit soon drifted into the county with 
which the parish was almost always coterminous. Bacon's Laws Chap. VI. of Maryland, 1694, provide for the laying out of a common for a new town. This was the usual course of procedure. Long before this time it is probable that manors were given up. Copley to Lord Baltimore, April 3, 1638 , in Calvert papers, makes a strcng statement of the difficulty of maintaining them in Maryland.

Charter to Throckmorton, Yeardley, R. Berkley, and Smythe, Note $\mathrm{I}_{3}$, in Smith of Nibley MSS., 57: "And shall also within the said page 285. terme of seaven years grant to the said Adventurers ... letters and grants of incorporacion by some vsuall or fit name or title with liberty to them and their successors from tyme to tyme to frame and make orders ordinances and constitutions for the rule ... and directynge of all persons to be transported and settled vpon the land hereby intended to be granted," etc. This bears date February 3, 1618 (1619), and was no doubt the model on which many grants were made at that time. It indicated a liberal gif: of local autonony hardly to be realized without the granting of township government or of government by the borough or hundred. The colony of Virginia was to have no jurisdiction except in case of " tryals of matters of Justice by appeale or otherwise." This was precisely the case with the more independent torns in England. Gomme's. English Village Communities, generally.

But the uninclosed vacant lots on which speculators planned to build, and on which cattle were pastured, took the name of commons and held it all the way into the interior. Commons they are to-day, but the title and the thing are passing into swift forgetfulness. Boston Common remains a part of the original common land of the town, and there are some others.

The same men were reappointed by the Petsoe Vestry in 1699 . "oversears of the highways" for another year, "they having not Note 15 , page 290. perform'd the offiss thare unto belonging the year Past."

Harrison marks this difference in descent in Elizabeth's day: Note 16 "Burrow kind" where the younger is preferred before the others, page 293. "which is the custome of manie counties of this region"; also the woman to have the third of her husband's possessions.

Nasse cites the statute of 1488 , chaps. xvi and xix as marking Note 17 , the beginning of inclosures of commons. The last was "An act page 294. 
CHAP. VI. against pulling down of townes." It had no doubt begun somewhat earlier. In 1513 a law of Henry VIII prescribes that the " pulling downe and destruction of townes within this realm, and laying to pasture lands which customably have been manured and occupyed wyth tythage and husbandry," should be restored. So the succeeding acts of 24 and 25 Henry VIII. The reformer Becon denounces the "wrong they have done to the poor commons, as by making common pastures severai to themselves," etc. Fortress of the Faithful, 598. The character of Latimer's sermons against the abuse is well known. In 1549 the peasantry rose in an endeavor to restore the commons. Harrison says in I 577 that some "daily do make beggars inough whereby to pester the land espieng a further commoditie in their commons, holds, tenures, dooth find such meanes as therby to wipe many out of their occupiengs, and turne the same unto his private gaines." Holinshed, i, 308. In 1607 riots are noted against inclosures of commons and wastes. Nichol's Poor Laws, 232. There is a sermon on the Rainbow preached at Paul's Cross in 16 17 by Bourne, in which he graphically says: "Depopulaiors have inclosed fields, townes, churches, and all, pulling those down which their religious forefathers did build up, stopping doores with thornes and their windows with brushes; yea, covering their roofs with thatch; nay, leaving them naked or else turning these holy places into barnes or sheepcoates or other prophane uses," p. 47. See also Stafford's A Brief Conceipt of English Pollicy, 1632. Harleian Miscell. ix, 199. The extracts that might be quoted are all but innumerable, but Marshall in 1786 shall end these where he says that the spirit of inclosure is such that in half a century more an open field or undivicled common may be rare. It was the cry of oppression at first, when the change to sheep farming was made. Selden says Depopulatio Agrorum is a great offense in the common law. And yet this revolution in agriculture, so unjustly enforcerl, was beneficial to England. The peasants thrown out to beg lived or died accorrling to their shiftiness. The cruel law of natural selection destroyed those unable to adapt themselves; human advancement is pitiless and unforgiving.

Note 18 , page 294 .

Chamberlayne's State of England, All the volumes after i 7 Io say of villanage, "But this kind of tenure is in a manner out of use." I am aware that this brings serfdom further down than the authorities by a hundred and fifty years. The copy I consulted lacked the volumes between 1702 and 1708 , but the change 
takes place in that interval. Serfdom went out before this time; it had practically been out of use for long generations.

Servants hired or apprenticed “"were subject to be corrected by their Master or Mistress, and resistance by a servant is punished with some severe penalty," says Chamberlayne. A fatal blow from a servant to a master was petty treason, and brought on him capital punishment. He had no redress for ill treatment. 'The hired servant as well as the apprentice might be sold for his unexpired time. He must work for a price fixed by others, and no man would hire him without the pernission of his former master. He was a slave for a time in all but name. Any combination on the part of the employed looking to a strike was treasonable.

NOTE.-I have reserved the Carolinas and Pennsylvania until they can be fully treated. Their history in the serenteenth century is short. 



\section{N D E X.}

Abbeys, places for the education of young people, $256, \mathrm{n}$. I.

Abce book, 21 $3 ; 258$, n. 4.

Aberdeen Burgh Records, 270, n. 28.

Abridgment of Philosophical Transactions, Sir R. Murray in, 42, n. 12 ; Dr. T. Robinson in, 42, n. 12.

Abstract of Records, 260, n. 9 .

Accomac County, Virginia, Records of, $7+, \mathrm{m}$. ; $148 ; 290, \mathrm{~m}$.

“Accommodation, an," 279; 287 ; town had refusal of, if sold, 239 .

Account of foundation of Society for Propagation of the Gospel, appendix to the sermon of $1706,167, \mathrm{~m}$.

Acosta's Hist. Nat., etc., 65, m. ; 9o, n. 20 ; IO2, m. ; IO3, m. ; I3I, n. 7 ; I33, n. I0.

Acre right, 279.

Acrelius, 132, n. 8.

Adam, the sin of, 177 ; criminal exhorted to repent of, 203, n. 25.

Adams's, H. B., Cape Ann and Salem, $275, \mathrm{~m}$.

Adams, John, ignorant of origin of commune, 280 .

Addison's, Joseph, essay on witchcraft in The Spectator, $46, n$. 18 .

Adrian, Pope, amulet worn by, 9o, n. 20.

Egineta, Paulus, Adams's Commentary on, $51, \mathrm{~m}$. ; extracts from Etius in, $5 \mathrm{I}, \mathrm{m}$. ; $52, \mathrm{~m}$. ; $57, \mathrm{~m} . ; 63, \mathrm{~m}$. ; 64, m. ; 7I, m. ; 8 I, n. $5 ; 85$, n. Iо ; 9 o, n. $20 ; 94$, n. 30.

Affections, natural, subordinated to duty, 193 .

African slavery, 303-305. See also Slavery, Slaves.

African speech left hardly a trace upon dialect, II 2 .

Ague, popular cure for, 92, n. 25 .

Alexipharmical mixtures whose virtues have no rational basis, 90 , n. 20.
Allen's, James, Election Sermon, $\mathrm{I}_{3}$, $\mathrm{m}$.

Alms-deeds, "liberalitie in, foundation for reward in eternall life," 170.

Altar fires, peril of kindling, with embers from hell, 29.

Ambassadors shut into Winthrop's house over Sunday, 162.

American, the, nimble-witted, but less patient and profound than the Englishman, I27.

American Antiquarian Society Transactions, $8, \mathrm{~m}$.

American herbs esteemed medicinal, 67,68 .

American Journal of Science, 132, n. 8.

American Philosophical Transactions, story of swallow taken out of slime in February, 44 , n. 13.

American remedies, 69-72.

American witchcraft, pamphlet bibliography of, 47 , n. 20 .

Americanisms borrowed from both ends of England, I09, I I 10.

Ames's, William. A Sound out of Zion, $\mathrm{I} 86, \mathrm{~m}$.

Ames's Almanac, I730, 107, m.

Amsterdam Pharmacopœia, formula in, 86, n. I 4 .

Amulet, mode of preparing a toad for an, 85 , n. Io; worn by Pope Adrian next his heart, go, n. 20.

Amulets, superstitious use of, 71 ; cure by similitudes found in treatment by, $84, n .7$.

Anabaptists, opinion about angels held by, 45, n. 15 .

Andromachus, physician to Nero, 63 ; added flesh of viper to universal antidote, 63 ; remedy of, lauded by Galen, 63 .

Andrews's Old Church Lore, 308, n. 3 . 
Angels, uncountable, turned round the crystalline spheres, 17 ; gave warnings by dreams, I8; classic dignity of Milton's evil, 22.

Anglo-Saxon culture developed in America, I.

Animal life, marvelous stories of, 15 .

Animal remedies in use in early colonial practice and in Europe, 72 ; 83, n. 7 .

Animals, American, popular use of, 69 ; named by descriptive epithets, Ioo; not easily fitted with English titles, ro5.

Antimony, sulphuret of, used by Jews, 94 , n. 30 ; one of the "seven wonders of the world," 94, n. 30.

Anti-ritualism, extremes of, 187 .

Antislavery movements, 305, 306.

Appeal to higher courts, right to, hampered and watched in Connecticut, 280.

Apple-eating on the Sabbath reprehensible, 16r.

Apprenticed servants treated as property, 296.

Apprentices, free, 295.

Aramatori the first to question equivocal generation of insects, 4I, n. I2.

Arcanum Lullianum, most secret mode of compounding the Universal Medicine in the, 88 , n. 16.

Archdale, tolerant Quaker Governor of South Carolina, I5O.

Archdale's Carolina, 150, m.

Argall, character of, 156 .

Aristotelis Secretum Secretorum, 37, n. 4 .

Aristotle observed everything, 48; circulation of the blood contrary to authority of, 49 .

Army worm regarded with wonder in Massachusetts, 39, n. 9.

Articles of Visitation. See CRANMER's ARTICIES, etc.

Asceticism, skimmed-milk, of the early schools, 209.

Ascham, Roger, praised cockfighting, I8I; on the barbarity of schoolmasters, 242 ; writes The Scholemaster, 242.

Ashton's Humor of the Seventeenth Century, 308, n. 7 .

Assimulate, curing by the, 57 .

Astrology, works on, esteemed, 5 ; crossed the wide seas with the emi- grants, 6 ; popularity of, 37, n. 6 ; opposed by some of the clergy, $37, \mathrm{n}$. 6 ; doctrine of correspondence connects closely with every other science, 37, n. 6 .

Astronomical Description of the Late Comet or Blazing Star, by Samuel Danforth, 35, n. 3 .

Astronomical errors in orthodox circles, 4.

Astronomy the science that touched the popular imagination, 3 .

Astruc's Histoire de la Faculté de Médecine de Montpellier, 95, n. 30. Atwater's New Haven, 236, m. ; 268, n. 24.

Aubrey, quoted in Prefatory Memoir to reprint of Exercitatio, 48, m.

Aubrey's Miscellanies, 9I, n. 21.

Auroras seen as swords of flame, 9 ; awful forerunners, 9 .

Austerities, Puritan, enforced with ruthless severity, I6r.

"Awakening, the Great," metamorphosed in to philanthropic agitations, I68.

Babylonical letter-learned physicians to be discountenanced, 79 .

Bacon, Francis, not known to the emigrants, 3; flounders in exploring coasts of physical science, ro, I I ; superstition of, 23 ; inclined to believe in weapon ointment, 60 ; remedy for colic given by, 84 , n. 9 ; scruples against idolatry shown by, I $5 \mathrm{I}$.

Bacon, Nathaniel, the Virginia rebel, last illness of, a divine judgment, II ; 40, n. II.

Bacon's Laws of Maryland, I49, m. ; 239, m. ; 3 II, n. I2.

Bacon's Natural History, II, m. ; 40, n. I $2 ; 60$, m. $; 8 \mathrm{I}$, n. $5 ; 85$, n. II. Bacon's rebellion in Virginia, people warned of, by signs, 8 .

Bailey's Andover, 235, m. : 237, m. ; 240, m. ; 261 , n. 9 ; 27I, n. 29 .

Bannister, the botanist, observed Virginia plants, 69 .

Baptism necessary to salvation, I75; of babes not always to be had in New England, 184; saving virtue accribed to, 200, n. $2 I$; value attached to, by the people, $200, \mathrm{n} .2 \mathrm{I}$; " the gate," 203, n. 26. 
Barbarism, mediæval, of the people, I8o.

Barbecue in general use in colonies, I33, n. I3.

Barber, surgical implements of, 74 .

Barber's Historical Collections of New Jersey, II 7, m. ; 204, n. 30.

Barber's New York Collection, 20, m.

B.arclay's Inner Life of the Sects of the Commonwealth, 186, m. ; 205, n. 32.

Barkly or Berkeley, sub-colony of, 285 .

Barrough's Method of Phisicke, a handbook in New England and Virginia, $54 ; 82$, n. 6 ; 94, n. 29 ; trauslated into the Indian tongue by Eliot, r69.

Fiarrow, the Separatist, 205, n. 32.

Farrowist system prevailed generally in New England, 204, n. 31.

Barton's Medical and Physical Journal, $57, \mathrm{~m}$.

Bartram, John, the Pennsylvania botanist, Observations, 136, n. I9.

l3artram, William, on swallows hibernating, 44, n. I3; Travels, roo, m.

3asilica Chymica, a Paracelsian book, $54 ; 85$, n. ro.

Bassompierre's Embassy, 87, 11. I4.

Bay Psalm Book used as a reader, 213. See also New England PSAlir Book.

Bayle, Pierce, inspired to write by comet of 1680, 39, n. 8 ; (Euvres de, 69.

Bayly's, Bishop, Practice of Piety, esteemed as almost divine authority, I22; translated into Indian tongue of Massachusetts, I22; much read in Virginia, 157 ; plan of salvation in, 168,169 ; reason for marvelous popularity of, 171 ; ethereal verbalism in, $199, \mathrm{n}$. 19.

Bean, kidney, good to strengthen the kidneys, 70 ; called Turkish bean, I03; 132, n. 8.

Bear baiting, the favorite Sunday amusement, I8I; not imported to America, $\mathrm{r} 8 \mathrm{r}$.

Beavers eaten on fish days, 15.

Beccaria's Dei Delitti e delle Pene, I99, n. I7.

Becon's Fortress of the Faithful, 312, n. 18.

Bede's Ecclesiastical Jistory of England, 208, m. ; 255 , n. r.
Bees produced by kine in decomposition, 10; 39, n. Io.

Beguin's Élémens de Clyymic, 9o, n. 20.

Behmen's, Jacob, De Signatura Rerum, 84, n. 8.

Lelknap's New Hampshire, 293, m.

Benevolence of New England more effective than that of the South, 288 .

Berkeley, Sir William, absolute in Virginia, 249.

Beschreibung und Contrefacture der Vornehmster Statt der Welte, r8I, $\mathrm{m}$.

Beverley's History of Virginia, I33, n. $10 ; 134$, n. $13 ; 223, \mathrm{~m}$.

Bezoar stone, a universal antidote, 64 ; mythical notion of origin, 65 ; used as a remedy in the colonies, 66 ; called by Castrillo "Regna de las Vénenos," 90, n. 20.

Bezoardick powder, ingredients of, 87, n. 14.

Bezoart, seven kinds of, g,o, n. 20.

Bible, enlarging influence of authorized translation of, 98 ; excluded from the service, 188,189 .

Birds, migration of, II, I 2 ; proved to grow on trees, 12 ; hiding places of migratory, 13.

Bishop escorted by one hundred and fifty horsemen, 17.

Bison named buffalo, roo.

Black powder, Stafiord's, a cure for smallpox and eruptive diseases, 57 ; method of preparation, $58 ; 85, n$. ro.

Blacks, enslavement of, not repugnant to the colonists. 303 .

Blackstone on witchcraft in his Commentaries, 46 , n. I8.

Blair, James, efforts of, for William and Mary College, 252; reply of Seymour to, 252 ; held his place as bishop's commissary for half a century, 253; fifty years' service brought no honors to, 254; students fired blank cartridges at, 270 , n. 28 ; instructions to, from General Assembly, 272, n. $3 \mathrm{I}$.

Bland's, E., Newe Brittaine, IO3, m.

Blanket, a colored, called a matchcore, ro6.

Blasphemy suppressed by laws and military orders, 147 ; punishment for, derived from mediæval codes, Ig6, n. 7 . 
Bleeding used by barbers and other humble practitioners, 53 .

Blight of 1665 attributed to execution of Quaker martyrs, I50.

Blood, circulation of the, theses on, in I660 and r699, 248.

Blue Book for 1867,268 , n. 23.

Boileau, in Arrêt Burlesque, ridicules belief in comets being ommous, 38 , n. 8 ; concerning circulation of the blood, 49 .

Bolton's General Directions, 204, n. 29.

Bonesetters, the, of early New England, 75 .

Book learning, lack of, compensated for, IO, II.

Book of Quinte Essence in E. E. Text Soc., $57, \mathrm{~m}$.

Books read in the colonies, I2I ; sent to Virginia in 16I9, 122; old, of seventeenth century libraries, I27, I 28 ; the first, 212.

Bossu's Nouveaux Voyages, I34, n. I3.

Boston, first witch trial at, in 1648 , 20; magistrate's wife at, hanged for a witch, 20.

Boston Common a part of the original common land of the town, 3II, $\mathrm{n}$. I4.

Boston peninsula, gates of, closed on Sunday, 163.

Boston Town Records, 226, m. ; 237 , $\mathrm{m}$.

Botany the foremost biological science, 68 .

Boucher's Causes, $26_{4}$, n. I6.

Bownd's famous treatise on the Sabbath, 157 ; I60; 163 .

Boyle's, Robert, Sceptical Chemist, 89 , n. 18.

Bozman's Maryland, r52, m. ; 238, m.

Bradford's Plymouth, I 50, m.

Bradstreet, Anne, beginner of New England poetry, on relation between elements and humors of body, 50 ; sings of the number four, 81, n. 3 ; wrote verses in imitation of $\mathrm{Du}$ Bartas, I23, I24; may have seen Hamlet in England, 139, n. 23 ; "a right Du Bartas girle," I39, n. 24; example of an educated woman in New England, 27 I, n. 29.

Braithwayt's Drunken Barnaby, 136 , n. $19 ; 169, \mathrm{~m}$.
Bray's General View of the Colonies, prefixed to sermon of $1697,263, n$. 14.

Brayley and Britton's History of Hertfordshire, 129, n. 2.

Breakfast, no, for schoolboys, 239; a meal not generally reckoned with, 240 ; none in Henry VIII's time, 259, n. 5 .

Brewster, Elder, had been a printer in Holland, 120.

Brickell's Carolina, 70, m. ; 72, m.

Brigham's Lowell Institute Lectures, 262, n. 12.

Brinsley on school punishments, 243.

Brinsley's, John, Consolations for our Grammar Schooles, 2I9, m. ; 220, m. ; 243, m. ; 264 , n. I7 ; 269, n. 27 , n. $28 ; 27$ O, n. 28 .

Brinsley's, John, Ludus Literarius, 214, m. ; 215, m. ; 216 , m. ; 217, m. ; 240, m. ; 243 , m. ; 258 , n. 3 ; 259, n. $7 ; 259$, n. $8 ; 269$, n. 27.

Brinsley, John, works of, most instructive to student of the history of education, 269, n. 27.

Bristol, England, chief center of colonial trade, 301 .

Bristol, R. I., established a school in I682, 239.

British Pharmacopœia, universal antidote expelled from the, 63 .

Browne, Sir Thomas, superstition of, 23.

Browne's, Sir Thomas, Vulgar Errors, 4, m. ; I5, m. ; I6, m. ; 4I, n. I2 ; $46, \mathrm{n} .19 ; 5.3, \mathrm{~m}$.

Brown's Travels, in Harris's Voyages, I5, m.

Buccaneers confessed their sins whenever a rich prize hove in sight, I 49.

Buchanan, George, called "the prince of poets of our time," I39, n. 23 .

Buckra, a name for the white man, I I2.

Buckwheat, Asiatic origin of, IO2; called Saracen corn, IO2.

Bull baiting forbidden by the colony of East Jersey, 204, n. 30.

Bullein's Dialogue against the Fever Pestilence, 93, n. 26.

Bullock's Virginia, Ioo, $\mathrm{m}$.

Bunyan's conscience awakenel by the "Practice of Piety," I69.

Burning to death in Boston and Cambridge, 182. 
Burroughs, George, the minister, hanged for his strength, 33 .

Burton's Anatomy of Melancholy, 13, m. ; 44, n. $13 ; 60$, m. ; 89, n. I 8 .

Bury Wills (Camden Society), 42, n. I2; 136, n. I9; 262, n. I2.

Burying in gardens and orchards, 183 . Bustard, Turkey, I30, n. 6.

Butler's Feminine Monarchie, 39, n. Io.

Byrd, William, of Westover, MSS. of, I4O, n. 25 ; the first man sent to England for education, 224.

Byrd's Dividing Line, I75, m.

Calamity, every, provoked by a particular sin, I5O.

Cal. Col. Papers, State Paper Ofince, I62, m. ; I83, m.

Calvert papers, 3 II, n. I 2 .

Camden's Brittania, 26I, n. II.

Cambridge Platform of $1648,205, n$. $3 \mathrm{I}$.

Campanius's New Sweden, IOI, m. ; IO3, m.

Campbell's, Charles, History of Virginia, 25I, m.

Campbell's, Lord, Lives of the Chancellors, I4O, n. 25.

Canones Regiminis Ecclesiastici, 206, n. $34 ; 206$, n. 35 .

Captives outlawed by "infidelity" enslaved, 303.

Cards, men and women staked at, 296.

Carew's, Richard, Survey of Cornwall, I3, m. ; 43, n. I3.

Carter, Colonel John, will of, $264, \mathrm{n}$. I6.

Cartwright, the Puritan leader of Elizabeth's time, maxim of, I47; tied Puritanism to temporal laws of Jews, I82; opposed to pagan names for children, I9o.

Casaubon's Enthusiasme, I656, 2I, m.

Castiglione, the Italian botanist, 69 .

Castiglione's Viaggio negli Stati Uniti, I31, n. 7 ; 132, n. 9 ; 133, n. Io ; I94, n. I.

Castrillo, a Jesuit, on astrology, 38, n. 6 .

Castrillo's Magia Natural, o Ciencia de Filosofia Secreta, 38, n. $6 ; 65$, m. ; 83 , n. 7 ; 90, n. 20 ; 9 I, n. 21 .

Cat, the black, 26.

Catechism, Assembly's, 195, n. 2.

Catechism, Calvin's, I95, n. 2.
Catechism, Cranmer's, of I548, I74; I98, n. $14 ; 198$, n. $15 ; 200$, n. 21 .

Catechism of John Robinson, 205, n. 32.

Catechism of Thomas Becon, I95, n. II ; 200, n. 2 I.

Catechism, the, the corner stone of the country school in Holland, 267 , n. $2 \mathrm{I}$.

Catechisms, writing of, regarded as a sort of heavenly vocation, 178 .

Caterpillars, necklace of, to cure ague, $7 \mathrm{I}$.

Cathartics of seventeenth century, $8 \mathrm{I}$, n. 5 .

Cathedral, scholars sustained in each, 257, n. 2.

Cathedral Commission, First Report, 256 , n. I ; 257 , n. 2.

Cattle might not be pastured in the common field on the Sabbath, I6I ; prayers of, at midnight on Christmas, II 7 .

Caulkin's History of New London, 2I3, m. ; 27I, n. 29.

Caxton's Prologue to the Eneydos, I 30 , n. 3 .

Census, aversion to, I9I ; attempt to secure a, in New York defeated, I92.

Century Magazine, $A$ pril and October, I894, I 37, n. I9.

Chalmer's Dictionary of Biography, 90, n. 18.

Chamberlayne's State of England, 295, m. ; 312, n. 18; 313, n. I9.

Chamberlen, Dr. Peter, attempted to organize women practitioners of midwifery, 77 .

Characteristics, English, lost, I27 ; national, a result of controlling traditions, I.

Chauncey's Cambridge, Mass., Almanac, $1663.7, \mathrm{~m}$.

Chauncey, President, Commencement Sermon of, $\mathrm{I} 63$, m. ; $265,-$ n. I9

Chevy Chase chanted to young people in the American woods, IIg.

Chief, generic English use of, 99.

Child's Scottish and English Ballads, I I $9, \mathrm{~m}$; $138, \mathrm{n} .20$.

Children, harsh penalties against disobedient, I42; not suffered to play on the Lord's Day, I6I ; of heathen parents damned for want of baptism, I74; pious and significant 
names for, I90 ; exclusion of, from baptism, 29I, n. 2I ; of the faithful included with their parents, 202, $\mathrm{n}$. 23 ; increase of number of, 229 ; shipped by the score as apprentices, 295.

Chimes, ringing of, on Sunday as great an offense as parricide, I99, n. I9.

Chinese medical theory of like cures like, 82, n. 7 .

Chinkapin, derivation of, I07.

Chirurgeons, name given to rough practitioners, 74 .

Christ, denial of the divinity of, a capital offense under Catholic law in Maryland, I49.

Christ Church parish, Middlesex County, Virginia, manuscript records of, 262 , n. I3.

Christ's Hospital, founded in 1553 , 257, n. 3.

Christiani on comets and other phenomena, 38, n. 8.

Christmas observance iniquitous, I 54.

Church, the first, in Massachusetts, organized to pacify the Lord's wrath, I 50.

Church attendance, difficulties of, in the Chesapeake region, 158.

Church constitution, earliest New England, 205, n. 32 .

Church going required by Argall, 156.

Church government, eccentricities of, I85.

Church music, people opposed to, I 88 .

Church officers, definition of, $205, \mathrm{n}$. 31.

Church organ refused by Brattle Street Church, 189 .

Churches, parish, had their schools, 257 , n. I.

Churchmen, Puritan and non-Puritan, cherished by church in Virginia, I84.

Cinchona tree, medicinal value of bark of, 68 ; most important of all modern remedies, 79 .

Cinderella known as Rose. Pink, and Piney in New England, 120.

Circulation, la, et ses Detracteurs, in Revue Scientifique, 49, $\mathrm{m}$.

Circulation of the blood first expounded, 48 ; French king petitioned to prohibit teaching of, 49 ; argued in master's thesis at Harvard 50 ; still a question at Harvard in 1699,50 ; ignorance of, in France, 53.

Ciuile and Vnciuile Life, Roxburghe edition, 218, m. ; 264, n. I5.

Clap's, Roger, Memoir, 144, m. : 166.

Class distinctions sharply marked, 194 , n. $I$.

Classification of vertebrates, unscientific, I4, I5.

Claypole's Manuscript Letters, I06, m.

Clayton, John, botanist, observations of the foundation for the Flora Virginica, 92, n. 24 ; I33, n. I2.

Clayton, John, Virginia parson, tells of use of bezoar stone as medicine, 66 ; observes Virginia plants, 69 ; collected 300 plants used as remedies by the Indians, 73 ; unflattering account of Virginia physicians given by, 75,76 ; author of papers in Transactions of Royal Society, 92, n. 24 ; to Royal Society, 93, n. 27 ; I03, m. ; I06, m. ; I30, n. 6; I 33 , n. Io.

Clayton, Rev. John, in Force's Tracts, 54, m. ; 76, m.

Clayton, Rev. John, in Miscell. Curiosa, Ioo, $\mathrm{m}$.

Clayton, Rev. John, in Philosophical Transactions, $133, n$. Io.

Clergy, mistaken zeal of, in witchcraft delusion, 28 ; the new based their piety on the supernatural, 30 ; had a fair acquaintance with medical knowledge, 76 ; wore no surplices, S4.

Clergymen, second generation of, in Virginia, 158 ; few in North Carolina in eighteenth century, I75; severity of, due to an ideal of conduct, iso.

Clothing, soft, not for humble people, I 44 .

Coaches rare enough in America to be noticeable, $250,25 \mathrm{I}$.

Cockfighting a Christian amusement in Virginia and Maryland, I82; opinions against, 204 , n. 29 ; forbidden in East Jersey, 204, n. 30.

Code of Massachusetts, I $45, \mathrm{~m}$.

Coke, astute jurist, superstition of, 23.

College at Henrico for Indian children, $220 ; 226$.

College ideals, $24^{6}$; curriculum of Milton's time "an asinine feast of sow thistles and brambles," 247. 
College of William and Mary, 222; 239; holidays allowed at, 24I; founding of, 250 ; richest institution of learning in America, $25 \mathrm{I}$; grams mar school of, 260, n. 9 ; charter of, 272 , n. 31 .

Collegiate School at Charles City, 220; Virginia Company added to endowment of, $22 \mathrm{r}$.

Collier's Ecclesiastical History, Lathbury's edition, 208, m. ; 256, n. I ; 257, n. 3 .

Colonial Records of Pennsylvania, 203 , n. 26.

Colonies, existence of, depended on supply of slaves, 303,304 .

Columna's, Fabius, Phytobasanos, 42, n. I2.

Comet heralded blight of $166_{5}, 7$; of $\mathrm{I} 68 \mathrm{O}$, a call froin heaven to Increase Mather, 8 ; alarmed Dutch on upper Hudson, 8 ; made English colonists talk about reforming their morals, 39, n. 8 ; awakened discussion in Mexico, 39, n. 8.

Comets and other portents, dread of, 6 ; prognostication by, 6 ; beliefs' concerning, 7 .

Comets, works on ominous character of, a considerable element in European literature, 38 , n. 8 .

Common fields, three, in primitive towns, 279; 282; animated scene in the, $279 ; 308$, n. 6 ; in closure of, threatened, 280 ; 308, n. 7 .

Commons, who should have the ? 277 .

"Commons" granted to a "hundred," 285.

Communal plan adopted from New England to Delaware, 281 .

Comnune, the town, very primitive, 277 ; what was this village? 278 ; in England in seventeenth century, 279 ; in America, 280; 286 ; 309, n. IO; Plymouth and Salem organized on the plan of the, $28 \mathrm{I}$ : in Long Island and New Jersey, 285 ; circumstances unfavorable to, 286.

Complete Discovery of the State of Carolina, 132, n. 8.

Complete Report of Royal Catholic Commission, 207, $\mathrm{m}$.

Condemning men that they might be sold, 301 .

Confectio Alcarmas, an Arabic remedy, ingredients of, $86, \mathrm{n} .14 ; 87, \mathrm{n}$. I4.
Conjurations, minor, I I 7 .

Connecticut Records, I42, m. ; I47, m. ; 148, m. ; I 5 I , m. ; I 54, m. ; I 95 , n. 4 ; 282, m. ; 289 , m. ; 309, n. 10 .

Connecticut school of law of 1650 , 228.

Connecticut Valley Historical Society Collections, $\mathrm{r} 88, \mathrm{~m}$.

Conscience, supremacy of the, I)2I94; exercised on frivolous judgments, I93.

Conspiracy of indentured servants in Virginia, 298.

Contraries cured by contraries, 57 .

Convent schools and nunneries, young women sent to, 209 .

Conveyance, instruments of, $273 ; 307$, n. $\mathbf{r}$.

Convict servants, $300-302$.

Copernicanism made headway slowly, 3 ; stirred our modern wits, 4 ; preferred by early Harvard mathematicians, 4 ; Bishop Godwin declared his belief in doctrine of, $35, \mathrm{n}$. I ; a stone rejected of the builders, 36 , n. 3 .

Corn, use of generic word, IO3.

Corn cob called " huss," I05.

Corn husks, names for, IO4.

Cornishmen opposed the Reformation, 96 ; would not have Bible printed in English, 96.

Cotton's, An, account of Bacon's rebellion in Virginia, I I 5 ; example of a cultivated woman in Virginia, 27I, n. 29.

Cotton, John, comet at death of, 7 ; said Sunday began at sunset on Saturday, I60.

Cotton's letter to Lord Say and Seal in Hutchinson's Massachusetts, 195-196, n. 5 .

Cotton's, John, Abstract of Laws, I4I, m. ; I 45, m. ; I47, m. ; I95, n. 4.

, Grounds and Ends of the Baptisme of the Children, I97, n. 9; 202 , n. 23.

- Holiness of Church Members, I $72, \mathrm{~m}$.

- , Phenomena quredam Apocalyptica, Dedicatory Letter, 204, n. 23.

- , Singing of Psalms a Gospel Ordinance, I $86, \mathrm{~m}$.

-., Way of the Churches Cleared, I9, m. ; 2OI, n. 2I; 205, n. 3I.

Court and Country, The, $213, \mathrm{~m}$. 
Court packed by Archbishop Abbot, 166.

Cows bequeathed to churches and schools, 262, n. I3.

Cox's, Marian Roalfe, Cinderella, I38, n. 20.

Cranmer's Articles of Visitation, 20, $\mathrm{m}$.

Cranmer's Reformatio Legum cited in First Cathedral Report, 257, n. 2.

Creatures, American, got second-hand names from real or supposed resemblances, Ioo.

Creatures, half-human, 15 .

Criminal of quality beheaded not hanged in Maryland, I44.

Crimp, the, and his doings, 295, 296.

Crisscross (or Christ's cross) row, 2 I 2.

Crocus metallorum, a universal cureall, 76 ; favorite Virginia remedy, 94 , n. 30 ; composition of, 94 , n. 30 .

Cross of St. George obliterated from the colors of the trainbands, I 5 I.

Crouche, Ralphe, Jesuit schoolmaster in Maryland, 238.

Culpepper's Commentary on the London Dispensatory, 93, n. 27.

Culpepper's Physitian's Library, 87, n. 14.

Culture, human, Puritanism made one great contribution to, $\mathrm{I}_{92}$.

Cunila Americana, name dittany settled on, 67 .

Customs, old English, revived, 265, n. 18 .

Dade's Almanac for $16 \$_{4}, 4 \mathrm{I}, \mathrm{n}$. I2.

Dafter for daughter, $134, n$. I4.

Damnation of non-elect infants, 175 , I 76.

Danforth, Samuel, amends his classics, Io $6, \mathrm{n} .6$.

Danforth's, Samuel, Astronomical Description of the Late Comet, $35, \mathrm{n}$. $3 ; 38$, n. 7 .

Danker's Journal, I. I. Hist. Soc., I 5 I, m. ; 215, m. ; 235, m. ; 298, $\mathrm{m}$.

Dante believed in migration of swallows, 44, n. I3.

Deane's, J. W., Sketch of Wigglesworth, $54, \mathrm{~m}$.

Declaration of the Colonie of Virginia, 220-22 I, m.

Dedham Historical Register, 244, m.

Dedham Records, 261, n. 9.
Deed, whole vocabularies of conveyance in one, 273.

Deerskin called match-core in Algonkin dialects, Io6.

Degrees, tests for, at Harvard, 248.

Democracy, "God did not ordeyne as

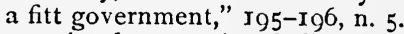

Demoniacal possession, belief in, unavoidable, 27.

Demons, house-haunting, 25; New England, visible, 26 ; cast in molds supplied by ancient tradition, 26.

Denifle's, Heinrich, Die Universitäten des Mittelalters bis I400, 272, n. 3I.

Denton's Brief Description of New York, 3Io, n. II.

Devil, a whistling, 26 .

Devils, materialistic conception of, in chains, 24, 25; sometimes visible, 26.

De Vries's Korte Historael, I32, n. 8.

De Vrics and Donne's, Cieo., MS., Bodlcian Library, 286, $\mathrm{m}$.

D'Ewe's Autobiography, 8, m. ; 78, m. ; 206, n. 36 ; 217 , m. ; 218 , m. ; $24 \mathrm{I}, \mathrm{m}$. ; 243 , m. ; $27 \mathrm{I}, \mathrm{n} .30$; 272, n. 30 .

De Witt's Historical Sketch of the Parochial School System of Holland preceding Dunshee's History of the Dutch Church School in New York, 267, n. 21 .

Dexter's Congregationalism, 205, n. 3 I.

Diabolism, waning belief in, I 7 I.

Digby, Sir Kenelm, made himself protagonist of sympathetic powder, 59 ; moral theism of, I95, n. 2.

Digby's, Sir Kenelm, Discourse on Sympathetic Powder, S6, n. I2.

-, Peripateticall Institutions, I7, m. ; 4I, n. I 2 .

Disease, critical days in, 80, n. 3 .

Disputation, the means of becoming expert in Latin, 215 ; rage for, in the schools, 26o, n. 8 .

District school, modern, development of the, 237 .

Disturbances, diabolical, occurred early in all the colonies, I9.

Dittany, same in name as ancient remedy Venus used in the Eneid, 66 ; Cretan and white, potent to cure poison, 66 ; to remove foreign bodies, 67 ; to assist in parturition, 67 ; virtues of, attached to pennyroyal, 67 ; 
works on, too numerous for citation, 9I, n. 22.

Diuretics of the seventeenth century, $8 \mathrm{I}$, n. 5 .

Divine right of high birth and official position, I4r.

Dock, Christopher, the Pennsylvania Dutch teacher, 240.

Doctrines, harsh, forged into formal creeds, 178 .

Documentary History of New York, iii, 8, m. ; i, I08, m.

Documents relating to New York, I92, $\mathrm{m}$.

Lonne's MS., 296, m.

Dorchester Records, 108, m. ; 226, m.

Louce's Illustrations of Shakespeare, 23, m. ; 43, n. I 2 ; I 8 , m.

I'rogheda, the pitiless slaughter of, I 79 .

Irunken people rare, 164.

Lryness favorable to understanding, $8 \mathrm{I}, \mathrm{n} .4$.

I) Bartas, Anne Bradstreet wrote clever verses in imitation of, 123, I24.

I)ucking stool and pillory, $28 \mathrm{o}$.

I)ufresnoy's Recueil de Dissertations sur les Apparitions, 45, n. I5.

I) uke of York's Laws, I49, m.

Durell's, John, View of the Government and Public Worship in the Reformed Churches, 206, n. 33.

1)utch alarmed by the comet of 1680,8 .

Dutch Drawne to the Life, 205, n. 32 .

Dutch Manuscripts, Calendar of, 77 , m. ; $165, \mathrm{~m}$.

Duties, primary, to those above you, I4I.

Dying, directions for, $\mathbf{I} 7 \mathrm{O}$.

Early English Text Society, No. 32 : Boke of Nurture, I 5, m. ; 41, n. I2 ; Vaughan's Fifteen Directions for Health in, 82 , n. 5 .

Earth, the, the center of universal motion for orthodox circles and colonial preachers, 4.

" East India School " at Charles City, Va., 220; 260, n. 9.

Ecclesiastical impropriety a heinous sin, 184 .

Ecclesiastics more ruthless than laymen, I8o.

Eclipses and other unusual phenomena beheld with awe, 9 .
Eden, Governor, and Blackbeard the pirate, 175.

Education, generally neglected, 29; continuity of, 207 ; its beginning in the early Christian centuries, 207 ; tradition and habit of, 209; cowand-calf endowment of, 226 ; religious motive for, 227, 228 ; popular, rough and scant, $23 \mathrm{I}$; legal obligation to provide, imposed, 232 ; of the few transformed into popular, 237 ; public, dominated by religion, 237.

Education, higher, in three colonies only, 254; 26I, n. Io.

Education, university and secondary, first aim of, to raise up ministers, 225.

Education, voluntary, among the Virginians, 263 , n. 14 .

Educational decline, alarm at the, 229 ; inevitable and universal, 233.

Edwards's, John, Cometomania, 7, m.

Effingham's instructions, 263, n. I4.

Egbert, account of austerities of, 255, n. I.

Egerton Papers, Abbot's Letters in, $\mathrm{r} 66, \mathrm{~m}$.

Eggleston's, Edward, The Beginners of a Nation, I55, m. ; I57, m. ; I9S, n. I4.

Ehralter Ritterkrieg, 88, n. I6.

Elder, a ruling, in the hierarchy, 185.

Elements of human body, 50.

Eliot, John, the Indian apostle, I2O; translated Method of Phisicke into the Indian tongue, I69; had a parish in Roxbury, 226; efforts of, to convert slaves, 305 .

Elliot, Rev. Jared, leading colonial writer on agriculture, 5,6 ; respect of, for the zodiac, 6 .

Ellis's Roxbury Town, 227, m.

Elizabeth, Queen, remedies used in time of, 93, n. 25, n. 26 ; reminded of the decay of learning, 210 ; reading Demosthenes with Roger Ascham, 242.

Enigrants not intellectual contemporaries of Milton and Shakespeare, 2 ; between 1620 and 1650 , bondsmen, 296.

Emotions, strong, enfeebled become the wisdom of the age, I99, n. I7.

Endowment, tenant and servant, for schools in Virginia, 22I; 227. 
England before the Revolution of I688 the mother country of the United States, I.

English-Americans in the first half of the seventeenth century, I. m.

English harvest, season for reaping English grains so called, I03.

English language an insular speech, 96 ; cleft into dialects, 97 ; never more effective than in hands of masters of the Elizabethan time, 97,98 ; sudden demand upon, 98 ; a misfit in wilderness of America, 99; adjusted itself to new environment, 99 ; cherished prejudices against foreign words, I07; all changes of usage accounted corruptions, I30, n. 4 ; left behind in the grammar schools, 2I5; 2I7; not taught in the schools until the fourteenth century, $257, \mathrm{n}$. I.

English studies drive out I.atin from the free school, 236 ; intruders in a Latin school, 26I, n. 9.

Ensign, the English, regarded as a gross idol, I5I.

Entail in the aristocratic colonies, 29I ; swept away by the Revolution, 293.

Ent's Letter in Willis's Translation of Harvey's IVorks, 4I, n. I2.

Erysipelas cured by fowl freshly cut open, 87 , n. 14 .

Ethics, theocratic, I45.

Evelyn's Diary, 9, m. ; 88, n. I5 ; 9I, n. $2 \mathrm{I}$; I3O, n. 3 ; I3O, n. 4.

Events, American, gave birth to American rhymes, 120 .

Exorcism, Spanish kings had gift of, 9I, n. 2 I.

Faillon's, Abbé, La Colonie Française in Canada, 3 IO, n. II.

Fairfax Seminary, parish records of seventeenth century in original MS. in, 234, m. ; 290, m.

"Fall" for autumn now mainly American, I36. n. I9.

Fanatics flourished in the colonies, 79 .

Farmer, the, could have no rights in common fields, 287.

Farms, granting of, discontinued, 284 ; a mode of landholding, 286 ; independent, driven to the wall, 287 .

Feline twang in London, IIo.

Felon, a high-born, favored, 144.
Fence, a portion of the, assigned to each cultivator, $282 ; 309$, n. 9 .

Ferule passes from seller to buyer of land in England, 276.

Fetichism, numeral, may be traced to Galen, 8o, n. 3.

Fever, pestilential, due to persecution of dissenters, I 50.

Field meetings, 279 .

Finespun propositions regarding the nature of God, I70.

Fitzstephen, 256, n. I ; 260, n. 8.

Fleming, Sir D., Account Book of, $8, \mathrm{~m}$.

Flies, strange swarms of, 9 .

Flogging, an age of, 297.

Folet's Molière et la Médecin, 40, $\mathrm{n}$. Io ; 48, m. ; 49, m. ; $52, \mathrm{~m}$.

Folk-literature the higher forms of folk-lore, II8.

Folk-superstitions, I I 7, I I 8 .

Folk-wisdom, bits of, transported to American shores, I I8.

Fonssagrives's Dictionnaire Encyclopédique des Sciences Médicales, 88 , n. I6.

Food must not be prepared on the Sabbath, I6I.

Foote's Virginia, 263, n. I4.

Force's, T. M., The Beginning, Progress, and Conclusion of Bacon's Rebellion, 8-9, m. ; 2OI, n. $2 \mathrm{I}$.

Forehead, blood to be drawn from middle vein of the, $82, n$. 6 .

Forsyth's Antiquary's Portfolio, 76, m. ; 95, n. 30 ; 131, n. 6 .

Forward, Rev. Justus, manuscript diary of, 132, n. $9 ; 261$, n. 1o ; 269 , n. 26 .

Franklin's, Benjamin, Poor Richard's Almanac, IIo.

Freedom, privileges of, sold, 294.

Friday a marked day in regard to weather, I 6 .

Friends of Germantown, antislavery protest of, 305 .

Frontier life dangerous to morals and manners, 264 , n. 18.

Frontiersmen find little time for learning, 233; knew no more of literature than did the Greck heroes, 234.

Fuller, the church historian, proverb used by, I I 4 .

Fuller's Good Thoughts for Bad Times, 203, n. 25. 
Fuller's Worthies, 26r, n. II.

Furmity, an English word first applied to corn, IO7.

Galen not revered, 50; bloodletting in persons under fourteen or over seventy forbidden by, 52 ; remedies in Virginia dating back to, 54 ; belief of, in virtues of theriac and mithridate, 63 .

Galenic age, fossil words of the, $5 \mathrm{I}$.

Galenism, simples but remains of, $5 \mathrm{I}$.

Galenist belief of Virginia doctors, 94, n. 30.

Galenists in England suspected of using spagyric methods, 54 ; numeral fetichism traced to, 8o, n. 3 ; strict, never sanctioned cures by sympathetic powders, 86, n. I 2.

Galen's Art of Physic in medical libraries, 54 .

Galen's De Antidotis Epitomes, 63, m.

Galen's De Dynamdiis, 82, n. 7.

Galen's De Theriaca ad Pisonem, $63, \mathrm{~m}$.

Galileo imprisoned, 4 ; Bishop Godwin's belief in doctrine of, $35, \mathrm{n}$. I.

Gaming, objections urged against, I54.

Gardiner, John Lyon, recorded difference in speech between two Long Island communities, 108 .

Gascoin's powder of calcined crabs' claws, 94, n. 30.

Gatford's Public Good without Private Interest, 20, m. ; I53, m. ; I84, m.

Geber quoted in De Via Universali, $62, \mathrm{~m}$.

Geddes's History of the Administration of John De Witt, 267, n. 21.

Generation, spontaneous, 9, 10 ; 4I42 , n. I2.

Gentleman Instructed, The, 40, n. II.

Gentleman's Magazine, Library of Popular Superstitions, 7I, m.; of I $830,17 \mathrm{I}, \mathrm{m}$. ; of $\mathrm{r} 828,270$, n. 28 .

Gerarde on dittany, 67.

Gerarde's History of Plants, 42, n. I2.

Gerhard's, Johann, Panaceæ Hermeticæ seu Medicinæ Universalis, 88, n. I6.

Gilbert's, Sir Humphrey, Queen Elizabeth's Achademy, 94, n. 29.

Girls not admitted to town schools, 244; candidates for wifehood at fourteen, 245 .
Glanvill, chaplain in ordinary to Charles II, 28 ; calls Addison and Montesquieu nullibists, $46, n$. I 8 .

Glanvill's Sadducisismus Triumphatus, 28, $\mathrm{m}$.

Glauber's Chemistry, in medical libraries, 54; De Auri Tinctura sive Auro Potabili, 61, m. ; 88, n. I5, n. $16 ; 89$, n. 18 .

Glover in Philosophical Transactions, Abridgment, $67, \mathrm{~m} . ; 70, \mathrm{~m}$. ; to Royal Society, 68, m.

God of that age worse than the worshipers, I73.

Godwin, Bishop, new theory of hibernation in the satellites, 13 ; his Voyage to the Moon, $1638,14, \mathrm{~m}$.; suggests doctrine of gravity and declares himself on the side of Copernicus and Galileo, 35, n. I.

Godwyn's, Morgan, Negro's and Indian's Advocate, 184, m.

Gold, potable, a most valuable remedy, 60 ; universal remedy for human maladies, $6 \mathrm{I}$; administered in solid state, 61 ; triplex nature of, 62 ; the tincture of the sun, 87, n. I5; allied with mercury, 88 , n. I6; statute forbidding the niaking of, repealed, 89 , n. 18 .

Gomme's English Village Communities, 280, m. ; $3 I I$, n. I3.

Goose, barnacle, develop from the shellfish barnacle, $12 ; 42, n$. I 2 ; served as fish on Fridays, I 2.

Gortonists should be hanged for constructive blasphemy, I8o.

Gospel Musick, or the Singing of David's Psalms, I86, m.

Gowan's Wooley, 67, m.

Grace for meals, $25^{8}$, n. 4.

Grammar schools. See Schools, FREE GRAMMAR.

Grant's, Mrs., Memoirs of an American Lady, 27I, n. 29.

Grave, sick servant required to dig his own, 298.

Green, Dr. S. A., private letter from, I08, m. ; in Massachusetts Historical Society Proceedings, 125, $\mathrm{m}$.

Green's Medicine in Massachusetts, 53, m.; 62, m. ; 72, m. ; 78, m. ; 79, m. ; 9 I, n. 21.

Green's, Dr. S. A., Groton in Witchcraft Times, $27, \mathrm{~m}$. 
Gronovius's Flora Virginica, 92, n. 24 ; I33, n. I2.

Groton, case of hysteria in, 27 ; quaint uses of words in, 108, 109.

Gullah dialect, I35, n. I6.

Hakewill's Apologie, I 5, m. ; I 7, m. ; 36 , n. $3 ; 37$, n. $6 ; 4$ I, n. I2; Deodati's Letter in Appendix to, 53, m. ; 54, m. ; I74, m. ; I97, n. II.

Declaration of the Providence of God, $126, \mathrm{~m}$.

Hale, Sir Matthew, jurist, superstition of, 23.

Hall, Bishop, prose of, almost as lofty as Milton's verse, I7 ; relates death of a philosopher for reasoning about thunderstorms, I8; ascribes thunderbolts to good angels, I9; on evil spirits, 24; opinion of cures without contaction, 60 .

Halle, John, in preface to Lanfranke's Chirurgerie, 93, n. 29.

Halliwell's English Dialects, I35-136, n. I9.

Hall's Cases of Conscience, 24, m. ; citing Thesaurum Exorcismorum, $57, \mathrm{~m} . ; 60, \mathrm{~m}$.

- Invisible World, $17, \mathrm{~m}$. ; $18, \mathrm{~m}$. Satires, 37, n. 6 ; I I 4 ; 258, n. 3 .

Hammond's Leah and Rachel, I 58 , $\mathrm{m}$.

Hanson's Old Kent, I98, n. I6.

Harleian Miscellany, I3, m. : II6, m. ; I 81, m. ; 204, n. $29 ; 267$, n. 21 ; 3I2, n. I7.

Harrison's Description of Britaine, in Holinshed, I5, m. ; 42, n. I2 ; I 6 , m. ; II 7, m. ; 210, m. ; 268, n. 25 ; 294, m.

Hartford, actions of gentle devil in, 25.

Hartwell, Blair and Chilton's Present State of Virginia, 224, m.; 272, n. $3 \mathrm{I}$.

Harvard, John, legacy of, for Harvard College, 247 ; library a part of, I2I ; source of inspiration of, 268, n. 23.

Harvard College, hospitable to new opinions, 50; student at, beaten for blasphemy, I48; attempt to compel conversation in Latin at, failed, 215; first graduate of, an Indian, 226; contribution for, from the sale of indigent children, 227; peck of corn from each family for,
229 ; graduates of, finding benefices in England, 229; ran down and kicked about as a political football, 235 ; younger pupils gave trouble at, 236 ; hours for meals at, 240 ; master at, dismissed for barbarous punishment of his usher, 243; older students at, not to be beaten, 244 ; foundation of, 247 ; poor scholars prominent in early appeals for, 260 , n. 9.

Harvard students placed in catalogue according to social position, I43; unable to speak Latin in 1689,259 , n. 7 .

Harvey, William, discovered that every animal is from an egg, 4I, n. I2; expounded to his students the circulation of the blood, 48 ; his physiology not accepted by men over forty, 48; trouble with Dr. Pott in Virginia, 74 : investigations of, broadened the field of human thought, 79 ; reverence for tradition shown by, 8o, n. I ; Life of, by Willis, $48, \mathrm{~m}$.

Harvey's Exercitatio de Motu Cordis, $48, \mathrm{~m}$.

- Prelectiones Anatomiæ Universalis, 48, m. ; 259 , n. 6 .

Hatfield House Manuscripts, 66, m. ; $87, \mathrm{n}$. I4 ; II $4, \mathrm{~m}$.

Hawkins, Jane, suspected of familiarity with the devll, I9.

Hazard State Papers, 2OI, n. 2 I.

Health drinking deemed abominable, I 53 ; law against, evaded, I96, n. 8 ; when introduced into England, I96, n. 8.

Heat favorable to imagination, $8 \mathrm{I}$, n. 4 .

Heathen parents, no room for salvation of infants of, 200, n. 21 .

Hell, the Puritan's, I73; the fire of, how fed, I 74 .

Henderson's School of Salernum, 82, n. $7 ; 95$, n. 30 .

Hening's Statutes, $22 \mathrm{I}, \mathrm{m}$. ; 249, m. ; 250, m. ; 262, n. I4.

Herbs, fancied resemblance between American and European, 67; names of European and their virtues given to American, 68 ; supposed to have pharmaceutical value, 68 .

Hermetic medicine, doctrine of, held by Winthrop the younger, 55 . 
Hibernation of migratory birds, I3; in the satellites, 13.

Hickory, derivation of, 107 ; nut called walnut, I33, n. I2.

Hippocrates used venesection with caution, 52.

Hippocrates, Aphorisms of, 50, m. ; 52, m. ; 8o, n. $3 ; 83$, n. 7 .

"Hired man" and "hired girl," I I3.

Histoire des Filibustiers, I49, m.

Historical Manuscript Commission. See MANUSCRIPT CoMmission.

IXit, for it, court English in Elizabeth's time, II2.

Ftoliness made merely relative, 172.

Holinshed, I 5, m. ; 257, n. I ; 312, n. I 7.

I lolland, school system in, 232.

Holy Club of Oxford, 167.

Home-lot right, 279; $2 \$ 2$.

H Lominy, derivation of, I05.

Homocentric notions of the world, 56 .

Hone's Every Day Book, quoting London Times, 46, n. I7.

Hooker, in Connecticut, made government auxiliary of the churches, I47; paper of, to prove the ensign harmless, I5I; held that Sunday began at sunset on Saturday, I60.

Hooker's Summe of Church Discipline, 20I, n. 21 .

Hornbooks, Latin in, 209 ; described, 212.

Horoscopes, mysteries of, little known, 6.

Horse's mane tangled by witches, I 18.

IIoskyns's Systems of Land Tenure, 307 , n. I.

Hours, school, 239, 240; in English schools, 269, n. 26.

House, delivery of possession of, 276.

Houses haunted, 25, m.

Howard's Collection of Letters, 136 , n. I9.

Howell, James, on witches, 2I, 22.

Howell's Familiar Letters, 4, m. ; 2 I, m. ; 53, m. ; 86, n. $12 ; 87$, n. 14 ; I 26, m. ; 258, n. 3 .

Huarte's, Juan, Examen de Ingenios para las Sciencias, 8I, n. 4.

Hubbard's Massachusetts, 206, n. 34 .

Hull, John, Diary of, IO3, m. ; 205, n. 3I.

Humanity made slight progress in seventeenth century, 307 .
Humble Advice of the Assembly of Divines concerning a Confession of Faith, The, I45; 200, n. 20.

Humors of human body congealed by Saturn, 37 , n. 4 ; relation of each one to elements, 50 ; qualities of, $5 \mathrm{I}$; mixtures and wrong doings of, $5 \mathrm{I}$, 52 ; black, cured by milk, 57 ; vital products of putrid, $40, \mathrm{n}$. II.

Hundred, the, and the borough, 285.

Hunter, Governor of New York, census taken by, I92.

Husband's Authority Unveiled, The, $\mathrm{I} 42, \mathrm{~m}$.

Husk, word used for bran, 132-133, n. Io.

Hutchinson, Goodman, complained of prisoners for tormenting his wife, 32.

Hutchinson, Mrs., doctress, services of, freely given, 78 .

Hutchinson Papers, I9, m. ; I 54, m.

Hutchinson's, Francis, Historical Essay on Witchcraft, $21, \mathrm{~m} . ; 23, \mathrm{~m}$. ; 46 , n. 17 ; the best, 47, n. 20.

Hypnotism, not recognized as due to natural causes, 26; girls at Salem show symptoms of, 30 .

Hysteria, not recognized as due to natural causes, 26 ; case of, in Groton, Mass., 27 ; girls at Salem show symptoms of, 30 .

Idol called a mawmet (Mahomet), ror.

Idolatry, scruples about, I50, I 5 I.

Illiteracy in the colonies, 235.

Imagination set on edge by theological speculation, r9.

Immigration, Puritan, ceased about I640, 229.

Indian college at $\mathrm{Henrico}$, benefactors for, 220.

Indian corn, names for, IO2 ; staple food product of colonists, IO4.

"Indian" doctors plying trade, 73.

Indian harvest, later ingathering of maize so called, ro3.

Indian massacre of 1622 attributed to sins in the colony, I49.

Indian remedies overestimated, 73 .

Indian summer, name of, taken from Indian harvest, I04.

Indian words unhandy vehicles for gossiping, 106, I07. 
Indians, American, doctrine of like cures like part of medical theory of, 82, n. 7 ; cured wounds by sucking, 93 , n. 28 ; cauterized with punk instead of cupping, 93, n. 28 .

Indians, captive, sold into slavery in Massachusetts, 306.

Infants, damnation of unbaptized, I 74 ; I76; 208 ; foredoomed, argue their case at the day of doom, I76; damned for Adam's sin, 177 ; elect, are saved by faith, 202, n. 23; Quakerism denied damnation of, 203 , n. 26.

Ingle's Letter in Historical Collections relating to the Colonial Church, 260 , n. 9 .

Inheritance in the colonies, 29I-293.

Inkhorne termes, I29, n. 2.

Instruction, wholly secular, unknown, 238.

Interest, scruple against taking, I9I.

Ireland, renowned monasteries of, 208 ; called Jack's Land, 289.

Irish rebels, curses on the, I 79 .

Isensee's Geschichte der Medecin, 49, $\mathrm{m}$.

Italy, fashions of all sorts from, IO3.

Jack's Land, 289.

Jag, a fraction of a wagon load, III.

James's, King, Demonology, 45, n. I7.

James, the pirate, captured transport ships, 299.

Jeffreys, George, and the Mayor of Bristol, 30I.

Jesuit missionaries learned medicinal value of cinchona, 68 .

Jesuit Relations, Burrow's reprint of, I3 I, n. 7 .

Jewell, Bishop, works of, 200, n. 21 .

Jingle, the familiar mnemonic " thirty days hath September," antiquity of, II6, II 7 .

Jones's, Hugh, Present State of Virginia, 127, m. ; $184, \mathrm{~m}$. ; 223, m. ; 25I, m. : 263 , n. I4.

Johnson's Dictionary, I30, n. 6.

Johnson's Ecclesiastical Laws, 255$256, n$. I.

Johnson's Higher Education in Rhode Island, 239, $\mathrm{m}$.

Johnson's Old Maryland Manors, 238, m. ; 286, m. ; $289, \mathrm{~m}$.

Jonson's, Ben, Alchemist, 40, n. II ; I5 I, m.
Jonson's, Ben, Gypsies, I69, m.

Josselyn on spontaneous generation, IO; on marvelous occurrences, 16 ; "God created nothing in vain," 68 ; an assiduous herb gatherer, 69 ; list of American remedies by, 70 ; description of nightingales in $\mathrm{New}$ England, Ioo ; on cormorants, I82.

Josselyn's Chron. Obs., 7, m.

- Two Voyages, 64, m. ; 68, m. ; 7o, m. ; 92, n. 25.

Journal of Sarah Eve, II7, m.

Judæus's, Philo, Creation of the World, $8 \mathrm{I}, \mathrm{n}$. 3 .

Judaism and the Puritan conscience, I60, I6I.

Judd's Hadley, 64, m. ; II3, m. ; I43. m. ; I54, m. ; 237, m. ; 244, m. ; 27I, n. 29.

Jusseraud's English Wayfaring Life, 260, n. 9.

Juvenis's, Joannes, De Medicamentis Bezoardicis, 64, m.; 90, n. 20.

Kalm's Travels, 44, n. $13 ; 69 ;$ I 35 , n. I8.

Kendall, An order touchinge the Free School in, 2II, $\mathrm{m}$.

Kepler developed foundations of modern astronomy, 3; followed Copernicus, $4 ;$ an astrologer, 5 .

Kepler's De Cometis, 4, m. ; 7, m. ; 38, n. 8.

Harmonicus Mundi, 4, m.

Kilty's Landholder's Assistant, 286, m.

King, submission to, dodged by Cotton, I46.

King's Majesties Declaration to his Subjects, The, I97, n. I2.

King's, Henry, Sermon at St. Taul's, 37, n. 6.

Knap, Elizabeth, contortions and ravings of, 27 ; susceptible to hypnotic influence, 27.

Knife sticking in the floor a lucky sign, II 7 .

Knight's Life of Colet, 240, m. ; 241 , m. ; 269, n. 26.

Knight's Questio Quodlibetica, 206, n. 36 .

Knox's, John, system of schools for Scotland, 232.

König's, Emanuel, Regnum Aninale, 7 I, m. ; 85, n. IO ; 93, n. 27. 
La'sadist's Journal, 70.

Laborers, English, bound themselves to service, 297.

Labors ceased every Saturday at three o'clock, I6r.

Laing, James, contempt of, for vulgar tongues, I29, n. I.

Lambert's History of New Haven and Milford, 9, m. ; 73, m. ; IGI, m. ; $i 62, \mathrm{~m}$.

Land, tracts of, reserved for the support of churches and local schools, 26 I, n. II ; little, held through feudal tenure, 274 ; communal holding of, primitive, 277 ; disposal of, by the town in New England, 278; distribution of, 282 ; processioning of, 291 ; 309, n. 8 ; held after the tenure of East Greenwich, 202.

Land and labor in the early colonies, 273.

Land law, one trait of, survived from the middle ages, $275 ; 307$, n. 3 .

Land-law terms, a jargon of, in England, 273; 307, n. I.

Land laws held to simplicity, 274.

Land tenure in Massachusetts and New England, 292.

Land warrants passed as current money, 276.

Landholding the direct ownership of the soil, 275 .

Landholdings, development of large, in Virginia, 224.

Landlord must give security for tenant, $28 \mathrm{~g}$.

Lane to Walsingham, IO2, $\mathrm{m}$.

Language, enriching of the, with Latin and French terms inevitable, I29, n. 2 .

Latham's Life of Sydenham, 68, m.

Latin, barbarous mediæval, used in records, 209 ; a gentleman's accomplishment, 222 ; all ministers should know, 225; few students of, 230 ; each church in Scotland to have a schoolmaster to teach, 232 ; crowded out by English studies, 236 ; widely diffused knowledge of, in middle ages, 257 , n. I ; constant use of, obligatory in English universities, 259, n. 7 ; colloquial use of, never found lodgment in America, 259, n. 7.

Latin schools, founding of, 209; 21 I ; small need of, by tobacco planters, 222.
Latin verses, the producing of, 217 .

Laud's Conference with Fisher, I 75, m.

Laws called liberties in Massachusetts, 274 ; earliest were simple and direct, 274.

Lawyers forbidden in the colonial courts, 273; 307, n. 2; but one among the Dutch, 274.

Leaming and Spicer's Grants and Ceremonies of New Jersey, 309, n. 8.

Learned, the, devoured the atrocious stories of Pliny, 16.

Lechford's Plaine Dealing, 20I, n. 2 I ; 204, n. 3I.

Lee, Mary, hanged as witch at sea, 20.

Lemnius's, Levinus, De Miraculis Occultis Naturæ, 40, n. II ; 6I, m. ; 89, n. I6.

Leniency protested against, I80.

Lents, keeping of three, a year, 208.

Le Page du Pratz's Histoire de la Louisaine, 13I, n. 6.

Lescarbot's La Conversion des Savvages, I3I, n. 7 .

Letters of Missionaries, $20, \mathrm{~m}$.

Lewis's Lynn, I89, m.

Libraries, typical, of the scholar, 123.

Library, a Virginia, of five volumes, I22.

Library, making a, by transcription, I4O, n. 25.

Library of All Faith's Parish, 138, n. 2 I.

Lilly's Grammar, 215.

Lincoln's Worcester, 235, m. ; 237, m.

Liruelo's, P., Reprouacion de las Superstitiones, $2 \mathrm{I}, \mathrm{m}$.

Literature, American, I23.

Livermore's Republic of New Haven, Town Records in, 236, m.

Livery of seizin, $275 ; 307$, n. 3 ; went out of use, 276 .

Lives of the Norths, $219, \mathrm{~m} . ; 247, \mathrm{~m}$.

Livingston and Smith's Laws of New York, 309, n. 8.

Local feeling had the intensity of patriotism in England, 108.

Logic the main study in all higher institutions, 246.

London Dispensatory, 86-87, n. I4; 94 , n. 30.

Longfellow's Evangeline, 71, m.

Lord Bateman, Scottish-English ballad of, became American, II9.

Lorrayne, physician of Faculty of Montpellier, 86, n. $14 ; 87$, n. I4. 
Lovell's History of Animals and Minerals, 43 , n. I $2 ; 7$ I, m. ; 85 , n. IO.

Lowly, justice demanded for the, in the name of religion, I95, n. I.

Ludwell MSS., 24I, m.

Luther, Martin, first Protestant example of extreme faith in witchcraft, 45 , n. I6.

Magistrate, a, sentenced his own daughter to the whipping-post, I93.

Magistrates, criticism of, little less than blasphemy, I 44 ; outvoted by representatives of the towns, 284 .

Magnetism, operation of weapon ointment and powder of sympathy attributed to, 59 .

Maize called Saracen corn, IO2, IO3; only a book word in America today, I03; Indian names for dishes prepared from, I05; Pliny's description of millet intended for, I3I, n. 7 ; confused with buckwheat, I3I, n. 7 .

Malgaine's Introduction to Paré's works, 82 , n. $7 ; 94$, n. $29 ; 95$, n. 30.

Manifesto filosofico contra los Cometas, by Sigurenza y Gorgora, opposed popular dread, 39 , n. 8 .

Manners, reformation of, by appeal to law, 167.

Manors entailed in England, 286; parts of mere village communities, 286.

Manuscript Book of Instructions, IO3, $\mathrm{m}$.

Manuscript Commission, $78, \mathrm{~m} . ; 82$, n. $6 ; 21 \mathrm{I}, \mathrm{m} . ; 256, \mathrm{n} . \mathrm{I} ; 26 \mathrm{I}, \mathrm{n} .9$; 267 , n. 21 .

Manuscript county records in Virginia State Library, 54, m.

Manuscripts, transcripts of printed books, 128 .

Maranta's De Theriaca et Mithridatio, $64, \mathrm{~m} . ; 83$, n. 7 .

Marriage at the hands of clerks, 184.

Marsden's Early Puritans, I39, n. 21.

Marshall's Rural Economy, 278 ; 308, n. 5 .

Maryland, reading and writing hardly known in parts of, 238 ; a "school for humanities" begun in, 238; laws passed for promoting Latin free schools in, 239.
Maryland Archives, I44, m. ; I64, m. ; 262 , n. I I.

Maryland Council Proceedings, 20, $\mathrm{m}$.

Maryland Historical Society Publications, No. 9, 238, m.

Massachusetts, Constitution of, framed in $1641,274$.

Massachusetts Archives, MS. Invoice in, $212, \mathrm{~m}$.

Massachusetts General Court undertook to send kidnapped negroes back to Africa, 305.

Massachusetts Historical Collections, vol. i, 45, n. I4 ; I45, m. ; vol. iii. Ioo, m. ; vol. iv, I90, m. ; vol. vi, 78 , m. ; I 40, n. 25 ; 248 , m.

Massachusetts Historical Society Proceedings, 58, m. ; Bennett MS. in, I64, m. ; Stoughton's Letter in, I5 I, m.

Massachusetts law of I64I against "crueltie," I 82.

Massachusetts Liberties, I44, $\mathrm{m}$.

Massachusetts Records, I9, m. ; 20, m. ; I 42, m. ; I 50, m. ; I5 I, m. ; I 54, m. ; I6o, m, ; I96, n. 8 ; 225 , m. ; 227 , m. ; 229, m.

Masson's Life of Milton, I29, n. 2 ; 246, m.

Master's degree at Harvard, subjects for, 36, n. $3 ; 50, \mathrm{~m}$.

Mather, Cotton, on existence of unseen satellite, 14 ; ascribes thunderbolts to work of devils, I9; shout of victory amid horrors at Salem, 28 ; never acknowledged himself wrong, 34 ; never forgiven for actions during Salem witchcraft, 34 ; had great hopes of what good angels might do for him, $45, \mathrm{n}$. I5 ; on Whait Winthrop as a doctor, 93, n. 27.

Mather's, Cotton, Magnalia, I $89, \mathrm{~m}$. : I96, n. $6 ; 203$, n. 25.

- Memorable Providences Relating to Witchcraft and Possessions, 30.

- Ornaments for the Daughters of Zion, 95, n. $3 \mathrm{I}$.

—, Ratio Disciplinæ, I52, m. ; 189, m. ; 206, n. 33.

Mather, Increase, relish of, for the supernatural and sensational, 7,8 ; conception of devils in chains, 24 ; Puritan ramshorn of, 28 ; bishop by brevet of New England, 30 ; books of, on eclipses, 30 , 
Mather's, Increase, Cases of Conscience, $26, \mathrm{~m}$.

- - Heaven's Alarm to the World, 8.

-_. Kometographia, 8.

_- Latter Sign Discoursed of, 8.

- - Meditations on the Sanctification of the Lord's Day, $\mathrm{i} 6 \mathrm{I}, \mathrm{m}$.

- - Remarkable Providences, I8, m.; I 9, m. ; 23, m. ; 24, m. ; 25 , m. ; 28 , m. ; $30 ; 41$, n. I2 ; 46, n. I $7 ; 92-$ 93 , n. 25 ; IO5, m. ; I36, n. I 9.

Matthæus's, Antonius, De Criminibus, 196, n. 7 .

Meals in the reigns of Elizabeth and James, 268, n. 25.

Medical professors, one of the most famous in Europe a woman, 78.

Medical students in Massachusetts, lack of knowledge in, 79 .

Medical theory expansive, 66.

Medical tradition, persistence of, 66 .

Medicinal virtue attributed to precious and rare things, 60 .

Medicine, dabblers in, 53; mystical tendency of, 58 ; in hands of clergy and women, 76 ; decline of colonial, 78 ; modern scientific born in seventeenth century, 79 .

Medicines administered when moon was in proper sign, $5 ; 36$, n. 4 ; to be given in odd numbers, $8 \mathrm{I}$, n. 3 .

Meehan's Monthly on American dittany, $67, \mathrm{~m}$.

Meeting, a young man whipped for not going to, on Sunday, I62.

Meeting-house substituted for church, I89.

Meeting-houses, seats in New England, "dignified," I 43 .

Melville, Andrew, in McCrie's Life of Knox, 266, n. 21.

Men of the woods, 127.

Mental furniture, antique, of the emigrants, II 7 .

Mercurial remedies, $60 ; 88$, n. 16 .

Merrymount, Maypole at, cut down, 153.

Mesmerism not recognized as due to natural causes, 26.

Michaelmas Protestantized into Miheltide, I 5 I.

Midwife officially appointed in New Amsterdam, 77.

Milk for Babes, in Prince Library, Boston, I6I, m.
Milton, John, a Puritan at the time of Cotton, 2 ; artistic passion of, 3 ; sonnet of, on Kingship of God, I7; classic dignity of his evil angels, 22 ; beaten by his tutor at Cambridge, 244 ; disappointed in the university, 246; his opinion of universities, 247.

Milton's University Oration, 4I, n. I2. Minister, the one educated man in the parish in New England. 287 ; dominance of, over the unlettered complete, 287.

Ministers act as soothsayers and play showmen of monstrous births, I6; two, in each church in New England, I85; all, should know Latin, 225 ; want of able, in Virginia, 249.

Mitchell's Past in the Present, 86, n. I3.

Mithridate, belief in virtues of, 63 .

Mithridates discovered a universal antidote, 63 .

Moisture essential to memory, $8 \mathrm{I}, \mathrm{n} .4$.

Molière's Malade Imaginaire, 52, m. ; 80, n. 3 .

Molière's Médecin Malgré Lui, 87, n. I4.

Monarchy and aristocracy both approved in Scripture, 196, n. 5 .

Monardes, first Spanish edition of, 92, n. 23; English edition, 65, m.; on bloodstone, 7I, m. ; 90, n. 20; 92, n. 23.

Monasteries, suppression of the, nearly abolished the education of the times, 210; the British, Irish, and Saxon, 255, n. I : perfect organization of the Catholic, 255, n. I.

Monmouth's rebellion, sale of the rebels of, 3 OI.

Monstrosities and marvels noted by members of the Royal Society, 16 .

Montesquieu's Esprit des Lois, 46, n. 18.

Months, scruples against ordinary names of, I52.

Moon, influence of the, 5,$6 ; 37, \mathrm{n}$. 5 , n. $6 ; 130$, n. 3 ; winter home of migratory birds, 14 .

Noral History of Frugality, I65, m.

Moral law made moral by divine command, 145 .

Moral passion of the present age, I41. Morality, ideal of, abrogated, 172.

Morton, Charles, elaborated theory of hibernation in the satellites, I3, I4; 
in Harleian Miscellany, I3, m. ; vice president of Harvard, 45, n. I4; lectures on philosophy, 45, n. I4.

Morton's New English Canaan, 133, n. II.

Movertus, first authoritative writer on insects in England, 39, n. Io ; 40, n. II.

Mugwump, an honorary title of leadership, 107.

Mulcaster on perfumes, 93, n. 26, advocated flogging, 242 .

Mulcaster's Positions, I88, m. ; 2 Io, m. ; 240, m. ; 257, n. I ; 258, n. 3 ; 270-27I, n. 29.

Múller's Science of Language, 43, $n$. I2.

Music, obsolescence of, in New England, I 88.

Music books, scruple against using, in service, I87.

Muskrat, other names for, I05, 106.

Mystic philosophy, salt, mercury, and sulphur the three elements in, 83 , n. 7 .

Mythology, picturesque, of seventeenth century, 18 .

Names, pagan, giving of, to children opposed, rgo; Hebrew, for children, IgI ; nouns, verbs, and participles used as, I9I.

Nation, The, April 22, I897, 264, n. I6.

Natives prohibited from powwowing, I53.

Necromancer "blown up " in Boston Harbor, I9.

Negro, philanthropic exertion for, at first wholly religious, 304 .

Negro speech as various as the tribes, III; words in modern dialect of Surrey, II2; preserved the worst in seventeenth century English, II 2 .

Negroes the cursed descendants of Cain, 303; confounded with the Moors, 303 ; bondage of, justified by their heathen condition, 304 .

Neill's Educational Development of Virginia, 22I, $\mathrm{m}$.

Neill's Virginia Vetusta, 262, n. I r.

New Amsterdam, impossible to enforce a strict Sabbath in, I65.

Newbury, actions of a spirit in, 25 .
New England almanac for I649, unique copy of, in New York Public Library, 39, n. 9.

New England Chronicle, r $88, \mathrm{~m}$.

New England cradled in religious enthusiasms, I 59 ; benevolence of, organized and systematic, 288.

New England Primer, Introduction to Ford's reprint of, 2I3, m.

New England Psalm Book, preface to, 186, m. ; I88; 202, n. 27 ; the socalled "Bay Psalm Book," I88, m.

New England Synod of I679, 205, n. 31 .

New-Englander, the, always a member of a community, and therefore civilized, 283 ; close-fisted and shrewd, 288 ; schooled in the town debates, 298 .

New Engli-h Dictionary, 212, m.

Newgate birds shipped to America, 300.

New Haven Colony Records, 226, m. ; 268, n. 24.

Newman's Rehoboth, 308, n. 5 .

Newport the great center of the Guinea trade, 306.

Newton, Sir Isaac, in praise of Boyle's reticence, 89 , n. 18 .

New York Historical Collections, 26I, n. II.

New York Society library, remains of Winthrop's library in, 121.

Nichol's English Poor Law, I93, m.

Nichol's Poor Laws, 312, n. I 7.

Nightingale, various birds so named, IOO, IOI.

Niles's French and Indian Wars, 78 .

North and South, contrast between, $286 ; 288$.

Norton, John, the Massachusetts Calvin, 145.

Norton's, Prof. C. E., Life of Anne Bradstreet, 139, n. 23.

Notes and Queries, vol. vi, 23, m.

Nowell's, Alexander, Cambridge Almanac, 6, m. ; 36, n. 3 ; 38 , n. 7 .

Noyes's, James, The Temple Measured, 204, n. $3 \mathrm{I}$.

Nugæ Antiquæ, $189, \mathrm{~m}$.

Numeration, passion for, emigrated to America, 8I, n. 3 .

Observation, habit of shrewd, compelled by exigent wants, I 2 .

O'Callaghan's History of New Netherlands, 77 m. ; I39, n. 21. 
O'Callaghan's Laws of New Netherlands, 165 .

Offenses, trifling, magnified, $\mathrm{r}_{53}, \mathrm{~m}$.

Olaus, Magnus, book of unbelievable things in the sixteenth century by, $13 ; 43$, n. 13 .

Oliver, Mrs., publicly whipped for reproaching Massachusetts magistrates, 144 .

Opinions, heretical, punished with death, 148, r49.

Ordeal by water used in trial of witches, $45, \mathrm{n}$. I 7 .

Ord's Life of Wilson, 44, n. I3.

Ordronneaux's Code of Health, 95, n. 31 .

Organs, scarcity of, r 88 .

Ovid on life from putrefaction, quoted by later writers, Io.

Owen to E. Harley, 78 , m.

Oysters not to be used in months without the letter $r$, Ir6.

Paganism, long-distance, I 52.

Pagans, Christians dominated, by right divine, 153 .

Palingenesis rejected by Rolfink, 4r, n. I2.

Palmer's Island, fruitless endeavor to plant an academy upon, 262, n. II.

Paracelsian books, shelf neighbors of Harvey and Culpepper, 54.

Paracelsian school, writers of, revised old doctrine of signatures, 55 ; Angelus Sala a member of the, 88 , n. I6.

Paracelsus, doctor of fire, 53 ; doctrine of signatures ascribed to, 55 ; cured like by like, $56 ; 83$, n. 7 ; used St. John's-wort to drive away phantasms, 57 ; black powder of, $8_{5}, \mathrm{n}$. Io.

Paracelsus's De Cutis Apertionibus, 56, m. ; 83, n. 7 .

- De Naturalibus Rebus, 84, n. 8.

- Opera, 57, m.

Paradise Lost largely history to contemporary readers, 18 .

Parasites bred from the body on which they lived, Ir; sign of misery and scourge of God, 40, n. II.

Paré, Ambroise, drew seven pounds of blood from a man in four days, 53 ; works of, 46, n. $19 ; 53$, m. ; 86, n. 13; 91, n. 20, n. 22; denounced weapon ointment, $86, \mathrm{n}$. I3.
Paré's, Ambroise, Surgery, 54.

Parish, the, of primary importance, 283.

Parish vestry, the, in Virginia and the South, 29o; transacts all town or county business, 290 .

Parker, Chief-Justice, declaration of, against swimming witches, $46, n$. 17.

Parsons, tavern-haunting, put up with, I75.

Pastorate, the double, 185 ; in Holland, 205, n. 32 ; gone to decay, 205, n. 3I.

Paulet, Robert, sent to Virginia as parson, esteemed as physician, 76 .

Peacham's Compleat Gentleman, I660, account of system of Ptolemy in, 35 , n. I ; on members of medical profession, 94, n. $39 ; 139$, n. $23 ; 243$, m. ; edition of I66I, I $41, \mathrm{~m}$.

Peacock pies concocted from turkey, IO2.

Peasley, Henry, founds a free school in Virginia, 221.

Pedro porco, sold for price of pearls, $65 ; 90$, n. 20.

Penhallow on eastern Indian wars, r98, n. r 5.

Penmanship, elaborate, taught, 218.

Penn, William, bought condemned rebels, 302 : concerned for the souls of the blacks, 305.

Pennypacker's Historical and Biographical Sketches, 102, m. ; 240, m.

Pennyroyal, American, virtues of dittany transferred to, 67 ; poisonous to rattlesnakes, 67 .

Perfumes, value of, for sickness, 93 , n. 26.

Perkins's Cases of Conscience, I44, m. ; 20.4 n. 29.

Perry's Collections, Virginia, 223, $\mathrm{m}$.

Peruvian bark in malarial diseases, 69 .

Pews, exclusive, of the great families, I43.

Pharisaism, unbearable burden of, I62; stage in human progress, I94.

Pharmacopœias ignored medicines of the alchemists and Rosicrucians, 63: loathsome substances found in, 72 ; for use of animal substances consult, 93, n. 27.

Phlegm, curious notions about, 80, n. 2 . 
Physic in the hands of old women and the clergy, 95, n. 30 .

Pictet's Tableau des États Unis, I94, n. I.

Piers Ploughman, prologus, 308, n. 6.

Pigeons, flights of, 9 ; $14 ; 39, \mathrm{n} .9$; applied to draw out poison, $87, \mathrm{n}$. 14.

Pine cones, green, remove wrinkles, 70.

Pioneers have no time to invent, 232.

Planter, the Southern, independence of the, 287 ; sons of, averse to commerce, 288.

Plants, American, popular use of, 69 ; opinions regarding medicinal value of, 92, n. 23 .

Plato's Minos, I96, n. 7.

Pleasure in the disasters of opponents, I66.

Pliny, " the greatest gull of antiquity," I6.

Pliny's Historiæ de Gentibus Septrionalibus, $13, \mathrm{~m}$.

Plymouth Records, I50, m. ; I9S, n. I5.

Pocahontas, title of princess given to, 99.

Poème Sur l'Élixir Royal, 84, n. 8.

Politeness the virtue of childhood, 214 ; rules of, in verse, 214.

Politics, platform of, found by Cotton in the Scriptures, 147.

Poole's Dialect of Forth and Bargy, I IO, m.

Poor, how to be rid of the, the problem of England, 293 ; sent a-wandering, 294.

Population in $1650,2$.

Porcupine, viscera of, searched for bezoar stones, $65 ; 90$, n. 20.

Porta's, John Baptist, Magia Naturalis, Io, m. ; 40, n. Io ; 43 , n. I2 ; 85 , n. II.

Possession, picturesque delivery of, $275 ; 307$, n. 3 ; 308, n. 4.

Pott, Dr., sent to Virginia, 53 ; methods of, 54 ; only physician in Virginia, 74 .

Powder, sympathetic, a cure of great notoriety, 59 ; stopped hæmorrhages, 59 ; 86 , n. I2; much esteemed, 63 ; called Zaphygian salt, 86 , n. I 2.

Prat's, Joseph, Order of Orthography, I34, n. I4.
Pratt, a surgeon of Cambridge, saved from banishment, 74 .

Preachers, education of, a matter of primary importance in New England, 225.

Preaching a sacrament above sacraments to the Puritan mind, 225 .

Price, Miss S. F., technical information regarding dittany received from, 9I, n. 22.

Primer, the New England, 213.

Primer, the third implement of learning, 213.

Primitive science, ideas of, 63 .

Primogeniture in the aristocratic colonies, 29I; in Massachusetts and Pennsylvania, 292 ; swept away by the Revolution, 293.

Primrose, Dr., adversary of Harvey, 48 ; his voice the voice of the age, 48.

Prince's Annals, October 15, 1629, r $89, m$.

Printing presses, utter prohibition of, 263, n. I4.

Prisoners, at Salem, charged with torturing children, 32 ; cast into dungeons, fettered, and tortured, 32 ; released by proclamation of the governor, 34 .

Processioning of land, 29I ; 309, n. 8. Productions, literary, in the first generation belong to English letters, I24.

Prognostication by comets, 6 .

Pronunciation, awkward, of the pioneer scribe, 234.

Property, pagan had no right to such, as a Christian might have use for, I 53.

Proverbial philosophy, our, dates from the time when epigrams were used, I 5 .

Proverbs the accepted coin of popular wisdom, II4; abounded in communities where utterance was trammeled, II 5 ; express smothered political passion, II 6 .

Psalm-singing, obligatory, 178 ; scruples about, I86; decay of, I87; "morall" and of perpetual obligation, 188 ; 203, n. 27.

Psalms, George Sandys's metrical version of, I79.

Psalms, Sternhold and Hopkins's version of the, 178,$179 ; 213$. 
Pundits in Philadelphia who followed Olaus, I4.

Punishment of students, law limiting, 244.

F'unishments, variety of, 193.

F'urgatory abolished by the government, 257, n. 2.

I'uritanism tied to temporal laws of the Jews, I82; made one great contribution to human culture, I 92 ; the weakness of, was the weakness of its age, I93; in New England felt recoil of Restoration of $\mathrm{I} 660$, 2OI, n. 21 ; small farmers susceptible to, $28 \mathrm{o}$.

Puritans, the, looked on Elizabeth's rule with disfavor, 27I, n. 29.

Puritans and Precisians to conform or leave the country, 197, n. I 2.

Purvis's Laws of Virginia, 249, m.

Putnam, Joseph, declared his detestation of witchcraft, 33 ; carried child to Salem to be baptized, 33 .

Putrefaction produced life, Io; meat made tender under rays of moon a form of, 37, n. 5 ; creatures engendered by, 4I, n. I2.

Puttenham's Arte of English Poesie, Arber's edition, 97, m. ; 98, m. ; I 29 , n. 2.

Quacks flourished in the colonies, 79. Quakers opposed to slavery, 305, 306.

Quarrel between minister and people at Salem village, 30 .

Quick, appendix to Mulcaster, 244, m. Quincy's History of Harvard College, 45 , n. $14 ; 227$, m. ; 235, m. ; 24I, m. ; 247, m. ; 259, n. 8 .

Quintessence, directions for alchemical processes to attain, 89 , n. I7.

Quitrents the lord's half-penny, 282; paid by the town in New York, 309 , n. 8 .

Rainbows recorded with a "Laus Deo," 9 .

Rank, reverence for, $\mathbf{1 4 2 .}$

Rattlesnake, American, used medicinally, 64 ; killed by smelling pennyroyal, 67 ; skin of, worn as a girdle, 71 ; antidotes for bite of, $66 ; 73$; 87, n. I4.

Rawdon, Marmaduke, Camden Society, No. 105, 90, n. 20.
Ray, John, on unicorns, in IIarris's Voyages, 15, m. ; slow to believe Redi, 42, n. I 2.

Raynaud's, Maurice, Les Médecins au Temps de Molière, 52, m.; 8I, n. 4 .

Recesses, no regular, for play, in the schools, 240.

Record Commission, Institutes Civil and Ecclesiastical, published by, 195, n. I.

Records of City of Canterbury, Ninth Report of Royal Commission on Historical MSS., 197, n. Io.

Records of Massachusetts Colony, I38, n. 20.

Records of Virginia Colony, 220, m. ; 3 IO, n. I2.

Recovery, common, forbidden by statute in Virginia, 292.

Redemptioners as schoolmasters, 264, n. 16 .

Redi, advocate of Harvey's doctrines, 42, n. I2 ; experiments of, showing that insects were not generated spontaneously, 42 , n. I 2.

Reeves's History of Law, 273, m.

Register of Christ's Church Parish, Middlesex County, Virginia, Io9, m.

Rehoboth, R. I., built in a semicircle, 308 , n. 5 .

Religion and beauty regarded as antagonists, I 89.

Religion treated as a mere propriety, I 59.

Religious but ruthless spirit in all churches and parties, I66.

Religious movements become political and social forces, I68.

Remedy, no recovery without a, 7 I ; existence of a universal, 249.

Renegades lost to their old lives in America, 297.

Rents of the lord paid by the town, 278.

Report on Burgh and Middle Class Schools in Scotland, 240, m. ; 268, n. $26 ; 269$, n. 26.

Report, Third, of Commissioners on Education in Scotland, 266, n. 21.

Reports of Clergy in Virgina Collections, 222, $\mathrm{m}$.

Rest, Puritan mind had no conception of, I6I, I62.

Results of Three Synods, I44, m. ; I63, m. ; 201, n. 21 . 
Retainers, liveried, of high sheriffs, I 7 .

Retrospective Keview, 23, m. ; 47, n. 20; I96, n. 8.

Revenge and religion commingled, I 79.

Reverence, spectacular show of, made to judges and governors, 144 .

Rhazes on Smallpox, 52, m.

Rhode Island, no mention of schools in the early colony records of, 238 ; school at Bristol in 1682,239 ; first organized into towns, 308, n. 5 .

Richard, Colonel Solomon, on barnacle geese, 43, n. I2.

Richard's, Colonel Solomon, Dissertation sur la Possession des Corps par les Démons, 45, n. I5.

Ridgely's Annals of Annapolis, 20, m.

Ridley's View of the Law, 265, n. I8.

Roasting ears an early name for green corn, I33, n. IO.

Roberti, the Jesuit, ascribed wart cures to the devil, 60 .

Robinson, John, the sweet-hearted pastor of the Pilgrims, I76.

Robinson's, John, Works, 202, n. 22.

Rodach's, Phædro von, Vom Stein der Weisen, 61, m. ; 88, n. $15 ; 88$, n. I6.

Rode's, Hugh, Boke of Nurture, E. E. T. S., II4, m.

Rogers's, Thorold, Work and Wages, 257 , n. I ; 289, m. ; 309, n. 8.

Rogues made and hanged, 294.

Rolfink, Werner, most learned of German anatomists, $4 I, n$. I2 ; rejected palingenesis in book on chemistry, $4 \mathrm{I}, \mathrm{n}$. I 2.

"Roost-cock" in English use earlier than the time of colony planting, I37, n. I9.

"Rooster," a word produced by American mock modesty, I37, n. I9.

Rosicrucians, weapon ointment derived from, $5^{3}$; sympathetic powder attributed to, 59; Gothic medicines traced to, 63 .

Roxburghe Library, Inedited Tracts, $213, \mathrm{~m}$.

Roxbury, free school in, supported by householders, 226.

Royal African Company of England, 303.

Royal College of Physicians, Roll of, $77, \mathrm{~m}$.

Royal Comm. Gawdy MSS., 77, m.
Royal Hist. M\$S. Comm. Report, \&, m.; Tenth Report, Appendix, 85, n. $9 ; \mathrm{I} 47, \mathrm{~m}$.

Royal Society, members of, investigated monstrosities, I6; relations of sympathetic cures and trials discussed before, 86, n. I2; Virginia writer in Transactions, I33, n. Io.

Royal Society Philosophical Transactions, Abridgment, 67, m. ; 73, m.

Royal touch, colonists cut off from remedy by, 9I, n. 2 I.

Ruggles's History of Guilford, Conn., quoted in Judd's Hadley, II3, m.

Ruminants in Chili and Peru yielded bezoar stones, 65 .

Runaways from Virginia in North Carolina, 298.

Rush, John, of Salem, 275.

Russell's Boke of Nurture, E. E. T.S., No. 32, $15, \mathrm{~m}$.

Rustic English, mixing up of variant forms of, 134, n. I5.

"Rye and Indian" known in eighteenth century, I32, n. 9 .

Sabbatarianism, James I tried to check tide of, 156 .

Sabbath, observance of the, I57; divine reverence paid to the, 160 ; the New England, had become a fixed tradition, I63; Dr. Bownd's work on the, 160 ; a strict, contrary to the freedoms of Holland, I65; to be devoted to religious duties, $198, n$. I4.

Sabbath breaking, first record of indictment for, I97, n. Io.

Sabbath keeping, strict, widely accepted, I55; laxity in, brought judgments, I63; I98, n. I5.

Sabbath law disregarded by early Virginians, 158.

Sackville, Sir Richard, complains of his "lewde schoolmaster," 242.

Sainsbury's Calendar, IO2, $\mathrm{m}$.

Saint, the prefix, omitted from familiar geographical names, $\mathrm{I}_{5} \mathrm{I}$.

St. John's-wort, various medicinal uses of, 56,57 .

Saint Paul's School, holidays allowed at, 241 ; foundation of, 257, n. 3 .

Sala, Angelus, ridiculed notion of drinkable gold, $88, n$. I6.

Salem village, a frontier town in 1692 , 29 ; had elements needed for witch. 
craft mania, 30 ; incredible glimpses of infernal world at, 30 ; population decreased and business of, suffered, 34 .

Salerno, a woman the most skillful physician at the school of, 95, n. 30 .

Salmon's English Physician, I 5, m.; 42 , n. $12 ; 44$, n. $13 ; 64$, m. ; 84 , n. $9 ; 85$, n. Io; Shröder quoted by, 86 , n. I2; recipes for making tincture of gold in, 83, n. 16.

Salvation, schemes of, an index of moral stress, I68.

Sandys, George, poet secretary to the Virginia colony, 35, n. 2 ; rendered Ovid into English verse, I21 ; I23; looked upon the wilderness as an enemy, 126; metrical version of the Psalms, I79.

Saturn, approach of, to be guarded against, 37, n. 4 .

Savage's Winthrop's Journal, I9, m. ; $\mathrm{I} 44, \mathrm{~m}$.

Scheltema's Geschiedenis der Heksenprocessen, 46, n. $17: 47$, n. 20.

School, a, in each local community, required by a central authority, $231 ; 236$.

School, American district, evolution of the, $209 ; 227,228 ; 237$.

School and breakfast, 239.

School, the dame, sprang up, 210; maintained at public expense, 237.

School discipline, severity of, believed to be beneficial, 242 .

School holidays allowed, $24 \mathrm{I}$.

School hours, 239, 240; in Aberdeen, 268 , n. 26.

School law of 1647 in Massachusetts, motive of the, 228-23I.

School laws, tricks and shifts to evade the, 234 .

School life in the age of American settlement, 239.

Schoolboys, breakfastless, 239; munching breakfast bread along the road, 240.

Schoole of Vertue, The, 2 I4.

Schoolmasters, harshness of, discussed in Cecil's chamber, 24I ; beat their pupils "like stock-fishes," 242 ; think themselves best when they teach little and beat much, 270, n. 28.

Schools before the Reformation, 256, n. $\mathrm{I}$.
Schools, country, for mere reading and writing, 230, 23I : sustained in part by enforced local taxation, 236 ; growth of, 237 ; began at six o'clock A. M., 239 ; kept cruelly long hours, 240 ; rooms used for, 245.

Schools, early Christian, 208, 209 ; old cathedral, supplied with lay teachers, 210.

Schools, elementary, in Scotland in I494, and for Latin, 266, n. 2 I.

Schools, free, founded by Henry VI, 257, n. 3 : endowed out of spoils of monasteries, $25^{8}$, n. 3 .

Schools, free, founded in Virginia, $221 ; 262$, n. I4.

Schools, free grammar, for beginners in Latin, 214; scholars in the, ignorant of English and of numbers, 216 ; writing taught in the, 216 ; the universal remedy, 219, 220; modes of sustaining, in New England, 226, 227; tax rate for, 227; religious motive for, 227 ; agitations for, in New England, 229; established by Massachusetts law of 1647,230 ; decline of the Latin, 235, 236; English schools, 267, n. 10; made obligatory by law, $265, n .20$.

Schools, free Latin, zeal for the founding of, in England, 209, 210 ; exotics in Virginia, 222 ; found friendly environment in New England, 225, 226 ; laws for promoting, in Maryland, 239; taught in Maryland by indentured servants or convicts, 264, n. I6.

Schools, monastic, connected with our modern systems, 207.

Schools, New England, decline of, 265 , n. 20.

Schools, private, sprang up in Virginia, 222 ; license fee exacted from. by Governor Howard, 223; offspring of law of demand and supply, 223 ; rustic, fairly numerous, 263 , n. I4.

Schöpf, German botanist, 69 .

Schot's, Gaspar, Physica Curiosa, 43, n. I2.

Schotel's Oud Hollandsch Huisgezin der Zeventiende Eeuw, 2II, m. ; 257 , n. 1; 267, n. $21 ; 27$ o, n. 28.

Scientific observation, lack of, in centuries preceding the eighteenth, 40 ,

n. IO. 
Scotland, each church in, to have a Latin teacher, 232.

Scripture teaching, gentler side of, obscured, 178 .

Scruple-breeders, 186.

Scruples at using the ring in marriage, I89; minor, 190.

Secular culture in Virginia, 158.

Seebohm's The Salic Law, 289, m.

Seebohm's Village Community, 308, n. 6 , n. $7 ; 309$, n. 8 , 9 .

Seizin, livery of, $275 ; 307$, n. 3 .

Self-interest in morals, I49.

Separatists, English, held to duality of pastoral office, 185.

Serfdom and apprenticeship, 293-295 ; motives for releasing from, $294 ; 302$.

Serfs granted freedom as fellow-Christians, 302.

Servant, title of, degraded, II 3 ; frontiersmen unwilling to be called, I35, n. I8; the sick, neglected, 298. Servants, apprenticed, treated as property, 296; horrors of the traffic in, 296 ; sifting of, by Massachusetts colonists, 299 ; obtained from dangerous classes, 299 ; some prosperous, 300 ; slaves for a time in all but name, 3I3, n. I9.

Servants, bond, shiploads of, in Virginia and Maryland, 286; white, in excess of blacks in Virginia, $286 ; 296$; sold in great numbers, 296 ; in the colonies, 296, 297 whippings of, 297, 298; secret burial of, prohibited, 298 ; convict, 300,301 .

Servants, Dutch, fled to New England or Maryland, 298.

Servants, English, fled to Dutch territory, 298.

Settlements, opening of new, produced demand for unskilled labor, 302.

Seven, the number, and its parts, $8 \mathrm{I}$, n. 3 .

Sewall, Judge, opposed importation of slaves to Massachusetts, 306 .

Sewall, Samuel, witch foolery believed by, 3I ; humble confession of, read at general fast, 34 ; annually kept day of humiliation, 34 ; on Eliot, the apostle, 204, n. 28.

Sewall's Diary, 9, m ; 16, m. ; 77, m. ; I37, n. I9 ; I44, m. ; I5I, m. ; I52, m. ; 189, m. ; $21 \mathrm{I}, \mathrm{m}$.
Shakespeare and Milton, artistic passions of, touched not the emigrants, 3 ; quotation from Julius Cæsar on humor, $5 \mathrm{I}$; punning form given to proverb by, II4; quotation from Romeo and Juliet about a witch, II8.

Sheep of a town in Connecticut paid all the corporate expenses, 282 .

Shell money, names for, 107 .

Shepard and Ransom in L. Swift on Election Sermons, 235, m.

Shephard's Select Cases of Conscience, I95, n. 3 ; Treatise on the Sabbath, I 95 , n. 3 .

Short Account of Several Kinds of Societies, $167 \mathrm{~m}$.

Sibley's Harvard Graduates, I $40, \mathrm{n}$. 25 ; 163 , m. ; 203, n. 24 ; 215, m. ; 268 , n. 23.

Signatures, origin of doctrine of, 55 ; 82 , n. 7 ; theories concerning, 55 , $56 ; 69,70$; medicinal, $56 ; 70 ; 82$, 83, n. 7 .

Sigurenza, Gorgora, on popular dread of comets, $39, n .8$.

Skepticism, wholesome scientific, born in the seventeenth century, 4I, n. I2.

Slander, punishments prescribed for, I94, n. I.

Slaughter's History of the Parish, quoted in Anderson's Colonial Church, 78 .

Slave trade, Newport the great center of, 306.

Slavery, an insignificant element of Virginia life in the seventeenth century, I98, n. 13; white, not done away in England till the eighteenth century, 295: more ancient than historic records, 303 ; black tide of, ever swelling, 307.

Slaves, black, most useful appurtenances of a plantation, 302 ; carried to Spanish colonies, 303 .

Slaves, first, in English America, 302 ; conversion of, did not invalidate his owner's claim, 304 ; efforts to convert, languid, 305; thousands of, sold into New England, 306.

Slaves, white, six thousand in Virginia, 296.

Smith, Erminnie A., in Powell's Second Bureau of Ethnology Report, 90, n. I9. 
Smith of Nibley Manuscripts, 74, m. ; I 22, m. ; I56, m. ; 26I, n. I I ; 285 , m. ; $31 \mathrm{I}, \mathrm{n} . \mathrm{I} 3$.

Smith's History of New York, I92, m. Simith's Oxford Tract, I05, m. ; I06, m. ; 107, m.

Smyth's Tour, I35, n. I8.

Snakeroot, Seneca, used as general medicine in Europe, 73; only American remedy in Valentine's list, 94, n. 30.

Social aspirants, ambitions of, repressed by fines, 143.

Social conditions affected speech, I 2.

Society for the Propagation of the Gospel, Letter to, in I 7or, by Governor Dudley, 267, n. 22.

Societies, religious, I66, I67.

Society in the South, $284 ; 288$.

Sot-weed Factor, 105, m.; 107, m.

Soul, human, in insurrection against barbarism, 209.

South Carolina, statutes of, Ioo, $\mathrm{m}$.

Southern people lacked the New England cohesion, 288.

Southerner, the, became hospitable and generous, 288.

Sparrow's Collection, 9r, n. 2 r.

Speech, common, ever-varying storehouse of, 97 ; barbarous, of the common people, I34, n. I4.

Spelling, bad, and clumsy writers, 233-235.

Spencer, Dr. John, protests against considering comets ominous, 39 , n. 8.

Spencer's Of Natural Prodigies, 7, $\mathrm{m}$. Spiders, use of, in cases of intermittent fevers, $7 \mathrm{r}$.

"Spirit," the, and his victims, 295; 302.

Spirits, evil, popular belief in active meddling of, I9; particularly active on the Connecticut, r9; have given proofs of their presence with men, 24 .

Spiritual existence, palpable evidence of, afforded by witcheraft, 28 .

Sports, brutality of, 180 ; relish for inhumane, I8r, I82; lawful to be used, I97, n. I 2.

Sprat's Royal Society, 42, n. I2 ; 44, n. $13 ; 86$, n. $12 ; 90$, n. 20 .

Sprengel, Kurt, on Mesue the younger, 87, n. 14 .

Sprengel's, Kurt, Apologie des Hippocrates, 8o, n. 3 .
Sprengel's Geschichte der Arzneikunde, 28 , m. ; 42, n. $12 ; 45$, n. 15 ; 47 , n. $20 ; 53$, m. ; 59, m. ; 88, n. 16 ; citing Sanctorius, $5 \mathrm{I}, \mathrm{m}$.

Sprengell, C., on Sentences of Celsus, $53, \mathrm{~m}$.

Sprengell's, Sir Conrad, Translation of Aphorisms of Hippocrates, so, n. 3 .

Springfield infamous by reason of witches, I9.

Sprites, groveling and grotesque, 22 ; not the offspring of theological speculation, 23; denounced as Christian devils, 23.

Stafford, Dr, of London, remedies prescribed by, $56,57,58$.

Stafford's A Brief Conceipt of En:lish Pollicy, 312, n. I 7 .

Stars thought to control human affairs, 5 .

State Papers, $300, \mathrm{~m}$.

State, subordination of the, to the Church, I46; I95, n. 4 ; education for the service of the, secondary to ministerial, $225 ; 227$.

Statutes at Large, 89, n. I 8 ; 260, n. 9. Stedman's, Edmund Clarence, Library of American Literature, I40, n. 24.

Steiner's Education in Maryland, Sollers in, 238, m. ; 260, n. 8 .

Sternhold and Hopkins's version of the Psalms, 2r3.

Stiles's MS., 140, n. 25 ; 308, n. 5 .

Stith's Virginia, I56, m.

Story's Journal, 200, n. $2 \mathrm{I}$; 202, n. 23 ; 203, n. 26.

Stoughton, Judge, witch foolery believed by, 3I.

Stow's Survey of London, 256, n. I ; 257, n. 3 .

Strachey, description of corn given by, IO4: account of Virginia, I32, n. 8 .

Strangers forbidden, 2 S9.

Stratford-on-Avon, disastrous conflagration in, 157.

Strongbow led colony of English who settled County Wexford in Ireland, I IO.

Strype's Annals of the Reformation, 258 , n. 3 ; Memorials, 258, n. 3 .

Sukey Fry, ballad of, I37-I 38, n. 20.

Sunday in pioneer Virginia, 155: of Elizabeth's reign, I55; in Virginia never a rigorous Sabbath, I59; 
painfully rigorous repose on, a badge of Puritanism, I60; effort of Puritanism to transform into a $\mathrm{He}$ brew Sabbath, 162 ; law concerning, Catholic in tone in Maryland, 164 ; sale of liquor on, in New Netherlands, 165.

Superstition, Protestant and Catholic zeal against, 20 ; part of fixed intellect of the age, 23.

Surgeon sent to each colonial settlement, 73 ; word, as professional distinction, disappeared from general use, 75 ; obliged to take apprentices, 78; not esteemed in England in the sixteenth and seventeenth centuries, 93, n. 29 ; one, a Dutch bond servant, 94, n. 29.

Surgeon's Mare, 'The, a book on medicine used by colonists, 94, n. 29.

Surgeons, scarcity of, 75 .

Surrey, Virginia, MS. Records, 276, m.

Swallows winter in clay of river bottoms, I3, I4; Scandinavian and other myths about, 44, n. I3.

Swearers, Endecott instructed to make good laws for punishing, I49.

Swearing, cold water a punishment for, I48 ; forbidden by God's law, I 97, n. II.

Swimming witches, a favorite amusement, I9; $21 ; 46$, n. I7.

Swineherd, the, $28 \mathrm{I}$; antiquity of the, 309, n. 8.

Sydenham Society: Dr. Ent's letter in Willis's translation of Harvey's works, 4I, n. I2 ; Adam's Commentary on P. Egineta, 5I, m. ; Aretæus of Cappadocia on Acute Diseases, 51, m. ; Paulus Aggineta, 82, n. 7 .

Sydenham's Opera Omnia, 94, n. 30 ; Epistle I, in English, 94, n. 30.

Sylloge Confessionum sub tempus Reformandæ Ecclesiæ, I Doctrinæ, caput xvii, in, 202, n. 23.

Symmes, Benjamin, founds a free school in Virginia, $22 \mathrm{I}$.

Symond's Diary, 97, m.

Table of the Astrological Houses of the Heaven, 5, $\mathrm{m}$

Tachenius, Otto, His Clavis, I I, m. ; 83, n. 7 .

Talking in the street on Sunday forbidden, 164 .
Tanner's Art of Physic, 65, m. ; Notitia Monastica, 255 , n. I ; 257 , n. 2. Taylor's, Jeremy, Life of the Holy Jesus, 200, n. $2 \mathrm{I}$.

Teachers ignorant and careless, 243.

Teaching, primary, done at home, 2 II.

Telephus, ancient legend of, 84, n. 7 .

Temple's North Brookfield, 237, $\mathrm{m}$.

Tenures, conveyance of, 275,$276 ; 307$, n. $3 ; 308$, n. 4 .

Themes of college graduates, 248 .

Theocracy, ideal of, evolved, 146 ; the best form of government, I96, n. 5 .

Theriac, origin of and beliefs concerning, 63,64 ; Iroquois had a sort of, $90, n$. I9 ; Venice treacle a worldfamed, 94 , n. 30 .

Thevet's, André, New found World or Antarctike awakened curiosity about medicinal value of American plants, 92, n. 23.

Thieves pardoned on condition of seven years' service in the colonies, 300.

Thomson, Benjamin, the renowned poet of New England, I25.

Thomson on the Plague, 82, n. 6 .

Tiraboschi on the production of fossil trees, II, m.

Tiraboschi's Storia della Letteratura Italiana, letter of Aramatori in, questioning equivocal generation of insects, $41, \mathrm{n}$. I $2 ; 68, \mathrm{~m}$.; cites from Odericus Vitalis, 95 , n. 30.

Toads, medicinal uses of, 57,$58 ; 85$, n. 10.

Tobacco, a thousand pounds of, paid as fee to Mrs. Livingston, 78 ; extraordinary medicinal virtues attributed to, 92, n. 23 ; cultivation of, in Virginia, 286.

Tolman's Education in Rhode Island, 226, m.

Topsell, note from, in E. E. T. S., No. $32,15, \mathrm{~m}$.

Torture, legal, to produce confession, in use in New England, 183.

Tote of English origin, 137, n. I9.

Touch, miraculous, of English kings, dated from the Confessor, 9I, n. 2I ; of seventh son almost as good as king's, 9I, n. 21 .

Town community perpetual tenant of the manor, 277 ; phraseology of the, $28 \mathrm{I}$; the prudentials of the, 282 ; 
309, n. Io; dead in New England, 289; paid quitrents as a whole in New York, 309, n. 8 ; in Delaware Bay, 285 ; 310 , n. II.

Town, corporate, responsibility of the, for the support of its school, 264, n. I7; political importance of the, 283; every vestige of the, destroyed in Virginia, 285; the taxpayer and the landowner, 287 .

Town government, primitive, $309, \mathrm{n}$. Io.

Town meeting the source of political power, 284 .

Town plan in Long Island, New Jersey, and Delaware Bay, 285; 310, n. II.

Town system preferred by New-Englanders, 285 .

Towns, few, escaped fines for neglect of school laws, 234 ; the sources of power, $23_{3}$; government fell into the hands of the, 284 .

Township in Massachusetts became the political unit, $28_{3}$.

Traveling on Sundays prevented, 164 .

Tree regarded as a part of the soil, $275 ; 307$, n. 3 .

Trials accompanied by great cruelties, 32.

Triton in Casco Bay, 15.

Tryal of Witches, A, before Sir Matthew Hale, $23 \mathrm{~m}$. ; Sir T. Browne's testimony at, $23, \mathrm{~m}$. ; Hale's charge, $24, m$.

Tuer's History of the Hornbook, 2 I 2, $\mathrm{m}$.

'Tunes, familiar, corruption of, 187 .

Turell's Life of Coleman, $\mathbf{I} 89, \mathrm{~m}$.

Turf, twig, and splinter, seizin by, $275 ; 307$, n. 3 .

Turk, the typical infidel, Ior.

Turkey, mottled eggs of, bred leprosy, 70 ; various names of the, IOI, IO2 ; allied with bustard, IO2.

Tusser's Points of Good Husbandry, 5 .

Tutors, private, bought from among the redemptioners, 22.4.

Tyler's, Moses Coit, History of American Literature, I 39, n. 24.

Tymme's Silver Watch Bell, I74, m.

Ultimogeniture, or "borough English,"” 293.

Unicorn observed on the Hudson, I5 ; horn of, an ideal antidote to poison, 83, n. 7 .
Unitarian branded for blasphemy, I49.

Universal antidote, notion of, in medicine, 63 ; contained over sixty ingredients, 63 ; known in England as Venice treacle, 63 .

Universities not recovered from scholastic grossness, 247.

University scholars, mendacity of, 260 , n. 9 .

Unlearned Chemist in Medical Libraries, 54 .

Upham, the industrious historian of Salem, 267, n. 22.

Upham's Salem Witchcraft, only reliable work on witches in Salem, 24 , m. ; 47, n. 20.

Uprightness of life mere sin, 172.

Usufruct of land and cattle the commonest bequest for benevolent purposes, 221 .

Valentine's day, choosing mates on, a taking God's name in vain, I54.

Valentinus's, Basilius, Triumph Wagen Antimonii, 57, m. ; 83, n. $7 ; 84$, n. $8 ; 85$, n. $10 ; 94$, n. 30 .

Vaughan's Directions for Health, I 5O, m.

Venesection denounced, 82, n. 6; not so common in England as in France, 82 , n. 6.

Venice treacle, universal antidote, $\sigma_{3}$; $76 ; 94$, n. 30 .

Venus, dittany used by, 66 .

Verbalism, ethereal, in Practice of Piety, I99, n. I9.

Vermin compounded as medicine, 72.

Vernatti, Sir P., in Sprat's Royal Society, 90, n. 20.

Vestry Book of All Faith's, MS. in Maryland Historical Society, I39, n. 21 .

Village community. See Commune, THE TOWN.

Village life of the North led to commercial development, 283.

Village plan lost in the larger agriculture of the South, 285; crowded out in Virginia, 287.

Village, the New England, same as the English farming community, 283 .

Villanage prohibited in the fundamental law of Massachusetts and Connecticut, 305 . 
Viper, the flesh of, used in antidotes, 63,64 ; the rattlesnake used as substitute for, 64 .

Virgil's Aneid, 66, m.

Virginia, A Perfect Description of, I00, m.; 106, m. ; 133, n. II.

Virginia, alarm in, on account of ministers, 249; college and free schools in, opposed by Berkeley, 249 ; college subscription raised, 250 ; mercenary lawyers ejected from, 273 ; 307 , n. 2 ; the Southern model, 290.

Virginia Brittania, I04, $\mathrm{m}$.

Virginia Calendar for $1688,137, n$. I9 ; I94, n. I.

Virginia Company endows a college at Henrico, 220 ; adds to endowment of Charles City School, 221.

Virginia Company MiS. Records, 220, $\mathrm{m}$.

Virginia, early, untouched by any strong religious sentiment, 160 .

Virginia Gazette, I37, n. I9.

Virginia Historical Register, 224, m. ; 262, n. I4; 263, n. I4.

Virginia Historical Society, Randolph MSS. in, I49, $\mathrm{m}$.

Virginia life, multitude of documents relating to, 197, n. 13; extremely, rural, 223 .

Virginia Papers, State Paper Office, 137, n. 19.

Virginia State Library, manuscript county records in, $54, \mathrm{~m}$.

Virginia, True Declaration of, 130, n. 6 .

Virginia Vestries, Early Manuscript Records of, I $70, \mathrm{~m}$.

Virginians trained to politics and social intercourse, I59; under curse for sacrilege, 183 .

Vitality, persistence of, II

Voëtius's Excertatio de Prognosticis Cometarum, 38 , n. 8 ; lays stress on bad reputation of comets, 38 , n. 8 .

Voltaire's Commentaire sur Beccaria, $22, \mathrm{~m}$.

Vossius on bees, 39, n. I0.

Voting, church, negative not taken in, I9o.

Wampum, derivation of, I07.

Ward, Nathaniel, bitter words of, against Irish rebels, $\mathbf{1} 79$.

Warts cured by rubbing with rind of pork, 60.

Wasps produced by decaying fruit, Io.
Watch-coat, a corruption of matchcore (blanket), Io6.

Waterfowl produced from wood rotting in water, 12 ; habits of, better known to pioneer than pedantic philosopher, 12.

Watkins's Law of Tenures, 308, n. 3 ; On Copyholds, 308, n. 4.

Watson's Annals, 73, m. ; 77, m.

Weapon ointment derived from Rosicrucians, 58 ; descriptions of its preparation, 59; much thought of, 63.

Weeden's Economic History of New England, 265, n. 20.

Wendell's Life of Cotton Mather, 45, n. 15 .

Wesley-Whitefield revival, The, I67.

Westminster Assembly on good works, I99, n. 20.

Westover Papers, by Byrd, 64, m.; $73 ; 73, \mathrm{~m} . ; 78$.

Wheat-raising in Massachusetts blighted by comet of 1665,7 .

Whippings of English servants, 297, 298.

Whiston's Cathedral Trusts, 257, n. 2.

White's, Andrew D., Warfare of Science and Theology, 43, n. I2.

White-Kennett Library, London, 167.

White, of Selbourne, on hibernation of swallows, $44, \mathrm{n}$. 13.

Whitmore's Introduction to Code of I660, I95, n. I.

Widows, ancient, church officers, 185.

Widow's third of husband's estate, 293.

Wife called "my woman," 136, n. I9; obedience the shining virtue of a, I42.

Wigglesworth, Dr. E., notice appended to funeral discourse of, $125, \mathrm{~m}$.

Wigglesworth, Michael, and the stable door, 163; the doggerel Dante of pioneer New England, 176.

Wigglesworth's, Michael, Day of Doom, I24, I25; I63; I72; I77; damnation scene in, $173 ; 202, \mathrm{n}$. 23 ; 202, n. $24 ; 203$, n. 26.

Wilderness, grand primeval, called "uncouth," I 26.

Wilkins, Alice, ailment of, cast by horoscope, $5 ; 36$, n. 4 .

Wilkins, Bishop of Chester, an able mathematician, $35, \mathrm{n}$. I.

Wilkin's works, 3, m. ; I4, m. ; 35, n. I. 
Willard, Parson, and Elizabeth Knap's hysteria, 27.

William and Mary gave freely for their college, 250.

William and Mary Quarterly, vol. ii, 54, m. ; 139, n. 23; for 1897,262 , n. 13.

Willsford's Scales of Commerce, 218, $\mathrm{m}$.

Wilson's Account of Carolina, I33, n. I I.

Winsor's, Justin, pamphlet bibliography of American witchcraft, 47, n.20.

Winthrop, John, the younger, pos. sessed works on astrology, 5 ; belonged to chemical school, 54,55 ; most noted master of medicine in colonial period, 56 ; books on subject of sympathetic powder imported by, 59 ; dabbled in alchemy, 62 ; orvned books on potable gold, 62 ; library of, 89 , n. I 8 ; 120.

Winthrop, IVait, son of John the younger, 62 ; an adept in panaceas, 62 ; turned nearly all Nature to medicine, 93, n. 27.

Winthrop's Journal, I5O, I5I, m. ; I 52, m. ; I86, m. ; I93, m. ; I96, n. $8 ; 206$, n. 34 .

Winthrop's Letter to Sir N. Rich, I9I, m.

Winthrop's Life and Letters, 206, n. 34 .

Witch, first, brought to trial in Boston, I648, 20 ; wife of Boston magistrate hanged as a, 20; weighed against church Bible, 2I ; with dog's body and woman's head, 27.

Witch excitements in nearly every colony, 20 ; elements for, at Salem, 30.

Witch literature of seventeenth century oppressively vast, 47, n. 20.

Witch panics in England, 21 .

Witch trials, Continental, reported for Englishmen, $2 S$.

Witchcraft, renascence of, 20 ; attempt to suppress, by death penalty, 2 I ; two hundred tried for, $2 \mathrm{I}$; accusations of, retracted, 27 ; evidences of spiritual existence afforded by, 28 ; mischiefworking, at Salem, $3 \mathrm{I}$; partisans of, overthrown, 33 ; extreme faith of Luther in, 45, n. I6; Addison's Essay on, 46, n. I 8 ; ferocious pursuit of those accused of, 194.

Witchcraft accusations on Long Island, I9.
Words, peculiarities in use of, I35-I 37 , notes.

Witches, swimming, a favorite amusement, 2I; IOO, OOO arraigned and executed by Christian judges, 22 ; sprites known as familiars of, 23 ; diabolical dance of, 24 ; ride on sticks, poles, or brooms, 30, 3I: persecution of, ceased after Salem trials, 34; how tortured in England, 46, n. 17.

Woman, a, the most skillful physician at salerno, 95, n. 30.

Woman hanged for cleanliness, 32 .

Women physicians not uncommon, 77 ; engrossed considerable share of medical art in New Jersey, 95, n. 30.

Women servants, degradation of, a source of evil, 299.

Women, singing by, objected to, I86 ; went to meetings veiled, r9o; Winthrop thought much learning dangerous to, 244; Mulcaster advised higher education for, 270, n. 29; teaching chiefly done by, $27 \mathrm{I}, \mathrm{n} .29$.

Wonder-working Providences, I9, m. Wood for schools delivered in November, 245 .

Wood, moon's influence on cutting, 5 . Wood's Athenæ Oxonienses, I68, m.

Wood's New England Prospect, Io6, m. ; 107, m.

Woodward's Rise of the Religious Societies, I66, m. ; I67, m.

World, the invisible, a reflection of the familiar material, 16 : near the end of the, $41, n$. I 2 ; a cosmic pharmacy, 56 .

Worship, right of prescribing modes of, denied, 163: obligation of, greater than moral duty, 183 .

Writing, elegance of the old decorative, I29.

Writing schools, 218; maintained at public expense, 237.

Wright's Domestic Manners and Sentiments in the Middle Ages, 256, n. 1 ; 260, n. 9 .

Wright's Literature and Superstition of England, vol. ii, essay $\mathrm{x}, 23, \mathrm{~m}$.

Yankee twang in London, IIo; carried from England to Ireland before Chaucer, IIO; transplanted to America, II I. 
Yellow dock still used as a cure for jaundice, 85 , n. 9 .

Yellow fever, epidemic of, attributed to the first United States census, I 92.

Yonge, Walter, Diary of, 9I, n. $2 \mathrm{I}$; $96, \mathrm{~m}$.

Young's Chronicles of Massachusetts, I49, m. ; I53, m. ; I6I, m.
Young's Subjects for Master's Degree at Harvard, $36, \mathrm{n} .3 ; 249, \mathrm{~m}$.

York County, Virginia, Manuscript Records, 74, m. ; 184, m. ; 223, m. ; 275, m.

Zeal, religious, without pity, I65, m. ; altruistic, evolution of, I66; for pity's sake, I67.

\section{Charles Alexander Nelson.}

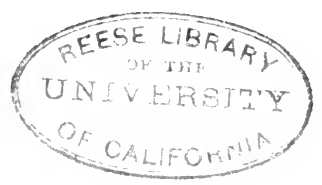

THE END. 

St 





\section{RETURN HUMANITIES GRADUATE SERVICE TO $\longrightarrow 150$ Main Library $642-4481$}

LOAN PERIOD 12

- 14 DAYS

4

\section{DAYS}

\begin{tabular}{l|l}
\hline 4 & 5 \\
\hline
\end{tabular}

ALL BOOKS MAY BE RECALLED AFTER 7 DAYS

Renewed books are subject to immediate recall

RETURN TO DESK FROM WHICH BORROWED

DUE AS STAMPED BELOW

MAY 15 '84.4 PA

KEIUNNED

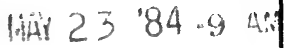

HUR RAAD. SERUE

MAY 21 '85-4 PAt

RETURNED

MÁY 228511

HUM. GRAD. SERVICE

UNIVERSITY OF CALIFORNIA, ,

FORM NO. DDI7A, 30m, 1/82 BERKELEY, CA 94720

$$
\text { ULT } \$ 5 \text { bs -4PM }
$$


GENERAL LIBRARY - U.C. BERKELEY

\section{B०00855433}

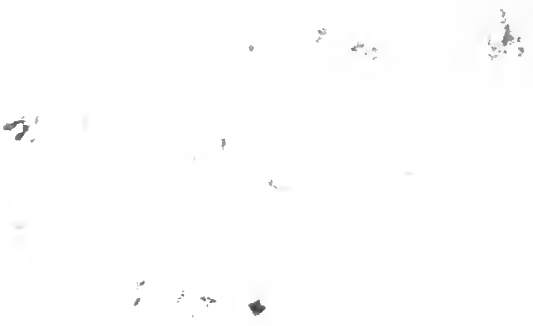


